
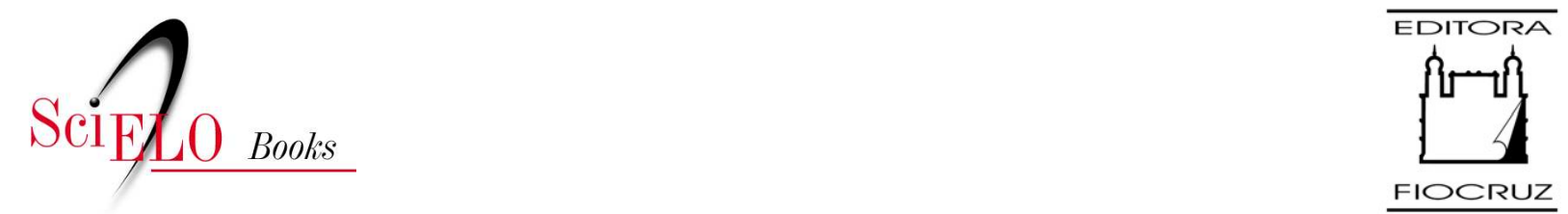

\title{
Recursos críticos: história da cooperação técnica Opas-Brasil em recursos humanos para a saúde (1975-1988)
}

\author{
Fernando A. Pires-Alves \\ Carlos Henrique Assunção Paiva
}

\section{SciELO Books / SciELO Livros / SciELO Libros}

PIRES-ALVES, FA., and PAIVA, CHA. Recursos críticos: história da cooperação técnica OpasBrasil em recursos humanos para a saúde (1975-1988) [online]. Rio de Janeiro: Editora FIOCRUZ, 2006. 204 p. ISBN 85-7541-102-0. Available from SciELO Books <http://books.scielo.org>.

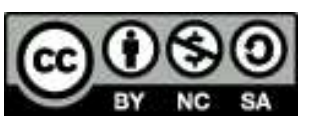

All the contents of this chapter, except where otherwise noted, is licensed under a Creative Commons Attribution-Non Commercial-ShareAlike 3.0 Unported.

Todo o conteúdo deste capítulo, exceto quando houver ressalva, é publicado sob a licença Creative Commons Atribuição - Uso Não Comercial - Partilha nos Mesmos Termos 3.0 Não adaptada.

Todo el contenido de este capítulo, excepto donde se indique lo contrario, está bajo licencia de la licencia Creative Commons Reconocimento-NoComercial-CompartirIgual 3.0 Unported. 


\section{Recursos Críticos}

História da Cooperação Técnica Opas-Brasil em Recursos Humanos para a Saúde (1975-1988) 
FUNDAÇÃO OSWALDO CRUZ

Presidente

Paulo Marchiori Buss

Vice-Presidente de Ensino,

Informação e Comunicação

Maria do Carmo Leal

\section{EDITORA FIOCRUZ}

Diretora

Maria do Carmo Leal

Editor Executivo

João Carlos Canossa Mendes

Editores Científicos

Nisia Trindade Lima e

Ricardo Ventura Santos

Conselho Editorial

Carlos E. A. Coimbra Jr.

Gerson Oliveira Penna

Gilberto Hochman

Ligia Vieira da Silva

Maria Cecília de Souza Minayo

Maria Elizabeth Lopes Moreira

Pedro Lagerblad de Oliveira

Ricardo Lourenço de Oliveira 


\section{Recursos Críticos}

História da Cooperação Técnica Opas-Brasil em Recursos Humanos para a Saúde (1975-1988)

Fernando A. Pires-Alves

Carlos Henrique Assunção Paiva

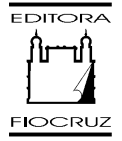


Copyright (C) 2006 dos autores

Todos os direitos desta edição reservados à

FUNDAÇÃO OSWALDO CRUZ / EDITORA

ISBN: 85-7541-102-0

Capa, projeto gráfico e editoração eletrônica

Carlota Rios

Imagem da capa

A partir da solução de Claudia Souz̧a e Silva para a foto Trabalhos de 'entrevista' domiciliar em uma das fazendas do município de Sumidouro, RJ. Fundo Ineru. Acervo do Departamento de Arquivo e Documentação da Casa de Oswaldo Cruz.

Autor desconbecido, c. 1960-1970.

Revisão e copidesque

Fernanda Veneu

Catalogação-na-fonte

Centro de Informação Científica e Tecnológica

Biblioteca da Escola Nacional de Saúde Pública Sergio Arouca

P667r Pires-Alves, Fernando A.

Recursos Críticos: história da cooperação técnica Opas-Brasil em recursos humanos para a saúde (19751988). / Fernando A. Pires-Alves e Carlos Henrique Assunção Paiva. Rio de Janeiro : Editora Fiocruz, 2006.

204 p.

1.Recursos humanos em saúde. 2.Cooperação técnica. 3.Planos e programas de saúde. 4.Organização Pan-Americana da Saúde. 5.Brasil. I.Paiva, Carlos Henrique Assunção. II.Título.

CDD - 20.ed. - 362.1042

2006

EDITORA FIOCRUZ

Av. Brasil, 4036 - Térreo - sala 112 - Manguinhos

21040-361 - Rio de Janeiro - RJ

Tels: (21) 3882-9039 / 3882-9041

Telefax: (21) 3882-9006

e-mail: editora@fiocruz.br

http://www. fiocruz.br/editora 


\section{SUMÁRIO}

$\begin{array}{ll}\text { PREFÁCIO } & 7\end{array}$

APresentação 9

Parte I. Estudo Histórico

1. Traços de um Contexto: saúde internacional, políticas nacionais e recursos humanos 19

2. Primeiros Movimentos: a gênese da cooperação técnica (1973-1976) 37

3. Os Primeiros Anos: o Ppreps em implantação (1976-1978) 53

4. Cooperação Técnica em Novas Bases (1979-1988) 71

5. O Legado dos Pioneiros 97

Parte II. Depoimentos

6. Diálogos com os Pioneiros 117

Entrevistas com Alberto Pellegrini, Carlyle Guerra de Macedo, Cesar Vieira, Danilo Prado Garcia, Izabel dos Santos, José Paranaguá de Santana e Roberto Passos Nogueira

7. Resenhas Biográficas 


\section{Prefácio}

Esta obra constitui mais uma contribuição do Observatório História e Saúde, sediado na Casa de Oswaldo Cruz - Fiocruz, para a reflexão sobre os processos de formulação e gestão de políticas de recursos humanos em saúde no Brasil, somando-se aos esforços que vêm sendo realizados pela Rede de Observatórios de Recursos Humanos em Saúde (ObservaRH), instituída em 1999, e coordenada pela Secretaria de Gestão do Trabalho e da Educação na Saúde, do Ministério da Saúde, com a cooperação técnica da Organização Pan-Americana da Saúde (Opas).

Os autores analisam, aqui, as origens e o desenvolvimento do Programa de Preparação Estratégica de Pessoal de Saúde (Ppreps), criado em 1976 como uma ação conjunta da Opas, do Ministério da Saúde e do Ministério da Educação e Cultura. Se podemos compreender o Ppreps como mais um capítulo da longa história das relações entretecidas pelo Estado brasileiro, durante o século XX, com os organismos internacionais no âmbito da saúde - a exemplo da Fundação Rockefeller e da própria Opas -, os autores inscrevem essa iniciativa no contexto nacional, marcado por transformações no âmbito das política públicas, impulsionadas pelo nascente movimento sanitarista, forjado em meio à resistência social e política ao regime militar.

Embora a formação e a capacitação de recursos humanos para a saúde integrassem a agenda programática da Opas desde os anos 40, tratava-se, na década de 1970, de ampliar o quadro técnico-científico para atender a diretriz política de aumentar o alcance da cobertura dos serviços médicos, 
especialmente nas áreas rurais, de modo a viabilizar, com foco nos cuidados primários em saúde, a regionalização da atenção e da assistência médica, de forma descentralizada e hierarquizada.

A partir de um ponto de observação privilegiado, este livro promove um mergulho na história da saúde, com base em extenso apoio documental, habilmente articulado a depoimentos orais concedidos pelos componentes da equipe pioneira do Grupo Técnico Central do Ppreps. Representa, assim, não apenas uma fonte de informações sobre eventos relacionados à aquisição de uma capacitação nacional em termos de recursos humanos para a saúde, mas uma referência reveladora das múltiplas dimensões - sociais, culturais e políticas - envolvidas na constituição do objeto saúde, demonstrando quão fértil pode ser o encontro da análise histórica com o campo da saúde.

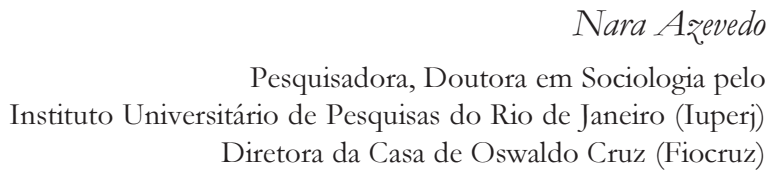

Francisco Eduardo de Campos

Professor do Departamento de Medicina Preventiva e Social da Faculdade de Medicina da Universidade Federal de Minas Geraes (UFMG) Secretário de Gestão e Trabalho e da Educação do Ministério da Saúde 


\section{APRESENTAÇÃO}

Em novembro de 1973, a Organização Pan-Americana da Saúde (Opas/OMS) e o governo brasileiro, representado pelo Ministério da Saúde (MS) e pelo Ministério da Educação e Cultura (MEC), firmaram em Brasília um acordo com vistas ao estabelecimento de um programa de desenvolvimento de recursos humanos para a saúde no país. Um ano e oito meses depois, em agosto de 1975, as mesmas partes voltariam a se encontrar para celebrar um Acordo Complementar, com o propósito de implementar o compromisso estabelecido dois anos antes. Em dezembro de 1975, um novo instrumento aditivo designou a Fundação Oswaldo Cruz (Fiocruz) como instituição encarregada da administração dos recursos orçamentários a serem transferidos pelo Ministério da Saúde à organização internacional para o financiamento das atividades do programa ${ }^{1}$.

Esses três instrumentos definiram as bases para ações de cooperação técnica entre as entidades signatárias, cujo ponto de partida foi a proposição, em junho de 1976, do Programa de Preparação Estratégica de Pessoal de Saúde, o Ppreps. A partir de então, esta sigla, assim como a própria cooperação Opas-Brasil em recursos humanos, estiveram diretamente relacionadas com processo pelo qual, nas décadas de 1970 e 80, se constituía no Brasil, sob a denominação de Desenvolvimento de Recursos Humanos em Saúde, um domínio cognitivo e um campo de práticas sociais e de políticas públicas.

Para as referências completas dos instrumentos mencionados, ver Opas/Brasil, 1973, 1975 a e b. 
Seus resultados e desdobramentos, da mesma forma, estiveram intimamente associados ao próprio processo histórico da moderna reforma sanitária brasileira, com implicações na organização do sistema de saúde no país.

O objetivo central do Ppreps, segundo os termos do seu primeiro programa de trabalho, era promover, tanto em termos quantitativos como qualitativos, a adequação da oferta de recursos humanos em todos os níveis às necessidades dos serviços de saúde. Pretendia-se, como horizonte estratégico, que um incremento significativo do número do pessoal formado e da qualidade da formação alcançada resultasse no fortalecimento do então recémcriado Sistema Nacional de Saúde (Ppreps, 1976)².

Esta orientação geral atendia a três objetivos parciais. O primeiro deles foi promover a formação em massa de pessoal técnico e auxiliar, ambos de nível médio, e de pessoal de formação elementar, tanto para cobrir os déficits já identificados, quanto aqueles prospectados a partir de uma esperada expansão dos serviços de saúde.

Com o segundo objetivo, pretendia-se promover a constituição e implementação de dez regiões docente-assistenciais de saúde. Neste caso, em um dado território, delimitado de modo a ser demograficamente expressivo e abranger em seu interior os três níveis de complexidade da atenção à saúde, buscar-se-ia estabelecer a gestão compartilhada dos serviços de saúde entre instituições formadoras de recursos humanos e as prestadoras de serviços. Considerava-se toda e qualquer unidade de atenção à saúde como um espaço potencialmente formador. E, em seu conjunto, integrados às áreas e regiões docentes-assistenciais, deveriam alcançar uma cobertura entre 15 a 20 milhões de pessoas.

Por fim, com o terceiro objetivo, visava-se apoiar a constituição daqueles que seriam os sistemas estaduais de desenvolvimento de recursos humanos para a saúde, integrados aos sistemas de planejamento setorial e regional correspondentes, sem descuidar das suas conexões com o planejamento em âmbito nacional e com as políticas de desenvolvimento.

Atingir esses ambiciosos objetivos iria requerer a mobilização de um amplo arranjo de instituições tanto em nível federal como estadual, e uma complexa gestão intersetorial. Entre as instancias a serem mobilizadas, além da Opas e do MS, se encontravam, por exemplo, no âmbito do MEC, os departamentos de

A descrição nesta introdução sobre o programa e seus objetivos baseia-se em Ppreps, 1976, e será retomada no capítulo 2. O Sistema Nacional de Saúde foi instituído pela lei federal de 6.229, de 17/07/1975. Ver Brasil/Leis e Decretos, 1975. 
Assuntos Universitários, de Educação Média e Ensino Supletivo, assim como o Movimento Brasileiro de Alfabetização, o Mobral. Entre outras áreas federais, figuravam o Ministério da Previdência e Assistência Social, recém-criado, o Ministério do Trabalho, o Ministério do Interior, a Secretaria de Planejamento da Presidência da República (Seplan), e as áreas especializadas em saúde e ação social das superintendências regionais de desenvolvimento, entre as quais a Superintendência de Desenvolvimento do Nordeste, a Sudene. Foi considerado fundamental o papel das secretarias de Saúde dos estados, como instituições centrais para a organização regional das ações a serem apoiadas pelo Programa. Igualmente decisiva seria a participação das universidades como centros formadores, em especial na constituição das regiões docente-assistenciais.

Ficou definida como função básica do programa atuar como promotor e instrumento catalisador de competências e capacidades, integrando e coordenando a participação de instituições e apoiando técnica e financeiramente as iniciativas. À Comissão de Coordenação, na qual se encontravam representadas as instituições signatárias, caberiam as tarefas de orientação e coordenação geral, a aprovação final de projetos, a celebração de convênios, além da supervisão político-institucional. Sua instância executiva - e decisiva na condução do seu desenvolvimento - era o Grupo Técnico Central (GTC), a quem coube o papel de núcleo técnico-gerencial. Suas principais funções eram empreender, de fato, a articulação entre as instituições, programas, e projetos, identificar necessidades, oportunidades e os recursos passíveis de mobilização, assumindo um forte componente político e organizador. Deveria, ainda, selecionar, orientar, e avaliar os projetos a serem apoiados pelo programa, assim como desenvolver modelos de atuação e abordagens inovadoras, rumo a patamares mais avançados de integração entre a docência e a assistência à saúde e a uma maior qualidade dos recursos humanos em saúde.

Dividido em duas partes, este livro discute, na primeira, em perspectiva histórica, os anos iniciais da cooperação técnica entre a Organização Pan-Americana da Saúde (Opas) e o governo brasileiro no domínio das políticas de Recursos Humanos em Saúde, tal como estabelecida a partir da celebração dos Acordos de 1973/75 e do advento do Ppreps em 1976. A gênese desta iniciativa, seus objetivos, estratégias e resultados, seus êxitos e vicissitudes serão examinados, assim como os seus legados para a própria conformação do campo dos recursos humanos no setor saúde.

$\mathrm{Na}$ segunda parte, são apresentados, sob a forma de uma espécie de diálogo simulado, segmentos editados de depoimentos orais prestados por 
personagens centrais dos processo de concepção e condução da Cooperação Técnica e dos seus programas pioneiros.

Examinar o percurso histórico do Ppreps e dos seus desdobramentos iniciais exige considerar, de saída, o seu contexto de criação e desenvolvimento. Muito do seu sentido resulta deste seu enquadramento, como uma resultante singular de uma modalidade de interação cooperativa entre uma organização intergovernamental das Américas, a Opas, e o governo do Brasil, na conjuntura das décadas de 1970 e 1980 e no âmbito das relações entre desenvolvimento e recursos humanos, na especificidade da saúde.

As organizações internacionais são atores poderosos em processos concretos de mudança. Elas produzem e difundem valores, normas e conhecimentos; elas freqüentemente instituem agências. Elas constituem aparatos, compreendidos como conjunto de recursos simbólicos, cognitivos e técnicos, de meios operacionais materiais e, eventualmente, financeiros. Todavia, estas organizações devem ser compreendidas também como arenas, como espaços de negociação, onde se encontram e interagem expectativas e interesses diversos. Suas agências nos países, as suas iniciativas "de campo" são particularmente permeáveis às aspirações locais e seus enunciados. Em uma terceira chave, elas podem ser percebidas, ainda, como instrumentos acessórios da própria capacidade de organização e operação dos Estados Nacionais, respondendo a determinadas necessidades em uma dada circunstância ${ }^{3}$.

Por outro lado, as organizações internacionais não são, obviamente, uniformes no tempo. Em seu percurso histórico, mudam os atores, as concepções e modos de operação. Face ao nosso objeto, vale a pena ter em mente, por exemplo, que o período em pauta registrou, no terreno das relações internacionais, a afirmação da concepção de "cooperação técnica" - como forma de interação de partes em condição de igualdade - sobre aquela de "assistência técnica", entendida esta como mais típica das situações de desigualdade e de reforço das relações de dependência entre os pólos desenvolvido/subdesenvolvido (Ferreira, 1976) ${ }^{4}$.

3 Para uma discussão sobre as organizações internacionais e os aparatos do desenvolvimento, ver Escobar, 1995. Para o poder normativo das organizações internacionais e da sua capacidade de induzir políticas nacionais, ver Finnemore, 1996. Para o tema das arenas de negociação nos encontros norte-sul, ver Stern, 1998.

4 Vale registrar que esta distinção das conotações e usos entre os termos - ajuda, assistência e cooperação - nem sempre é clara na literatura. Para um exemplo de uso indistinto na ciência política norteamericana, ver Breuning, 2002. Na Opas, porém, no período em questão, era visível a preocupação com os aspectos doutrinários desta diferenciação. Ver Ferreira, 1976. 
Portanto, tanto quanto examinar os enquadramentos relativos à inserção da cooperação Opas-Brasil em sua face internacional, é preciso inseri-la no contexto das políticas públicas nacionais, nos anos que se iniciam com a crise do chamado "milagre brasileiro" e do próprio regime autoritário e percorrem a longa transição rumo à democracia tal como a experimentamos hoje. Período que se inicia ainda sob a vigência da idéia do planejamento econômico em escala nacional, de uma concepção de Estado como idealmente responsável pelo provimento de recursos de infra-estrutura e de serviços essenciais, entre os quais os de atenção à saúde, e que vivenciarão a crise do endividamento e o ajuste fiscal, os constrangimentos da hegemonia ideológica de uma razão de mercado e o fim de qualquer otimismo desenvolvimentista.

Deve-se também, naturalmente, inscrever a Cooperação Opas-Brasil em Recursos Humanos e os seus programas no cenário das políticas de saúde, seja no plano das instâncias da saúde internacional, seja em âmbito nacional. Os anos 1970 foram, no plano internacional, anos de afirmação da saúde como direto, de reforço das demandas por expansão da cobertura da atenção à saúde, que culminam com a meta de Saúde para Todos no Ano 2000 e na definição da atenção primária à saúde como estratégia central.

A mesma década, também no plano da saúde internacional, consolidou uma transição na ênfase dos enunciados relativos à demanda por recursos humanos em saúde: da formação de médicos e demais profissionais de nível superior para a formação de pessoal técnico e auxiliar. Ambos os temas se articulavam, por seu turno, a uma identificada necessidade de aproximar os processos de formação da experiência concreta da prestação dos serviços.

Na contraparte nacional, o momento da criação do Ppreps corresponde ao da realização da V Conferência Nacional de Saúde e da instituição do Sistema Nacional de Saúde, ambos em 1975. Junto da criação do Ministério da Previdência e Assistência Social, do lançamento do Programa de Interiorização das Ações de Saúde e Saneamento (Piass), tais iniciativas, entre outras, correspondem a um movimento de expansão da cobertura da assistência médica que simultaneamente pretendia uma gestão mais racional da capacidade instalada e dos recursos em saúde. É, portanto, como parte deste movimento que a criação do Ppreps e seus desdobramentos imediatos devem ser considerados, como empreendimento dedicado aos temas do trabalho na saúde, da formação e desenvolvimento institucional dos recursos humanos em saúde.

O capítulo inicial da primeira parte discute exatamente os elementos constitutivos do contexto no qual se inscrevem a criação do Programa e os 
desenvolvimentos iniciais da Cooperação Técnica Opas-Brasil em recursos humanos. Considerar, ainda que de forma ligeira e assumidamente parcial, as várias dimensões contextuais presentes ajuda a atribuir sentido e estabelecer as condições de gênese do Ppreps. Auxilia também a compreender os rumos adotados nos seus desdobramentos posteriores.

O segundo capítulo se dedica, a partir dos enquadramentos e antecedentes discutidos no anterior, a construir o processo institucional e político de montagem da Cooperação e do seu programam fundamental, o Ppreps, seus objetivos, sua organização e formas de operação. Serão abordados os aspectos conjunturais imediatos e a formatação do programa, das suas instâncias de coordenação política e técnica. O capítulo se encerra com uma discussão quanto ao sentido estratégico da sua instituição.

No terceiro capítulo, discutem-se os principais resultados alcançados pelo Ppreps, até os anos de 1979/80, quando o processo de renovação do acordo-base refletia a introdução de mudanças relevantes na cooperação técnica Opas-Brasil, com uma significativa ampliação de seus objetos, com implicações no seu perfil político, organizacional e operacional. Esta reconfiguração da cooperação será discutida à luz dos rumos adotados no seu desenvolvimento inicial, dos seus êxitos e dificuldades, sempre em diálogo com o contexto da saúde no período em seus aspectos políticos e institucionais.

No quarto capítulo, examina-se o ciclo de renovação do Acordo de cooperação entre a Opas e os ministérios brasileiros, que em todas as suas implicações se inicia em finais de 1978 e se alonga até 1980, bem como os desenvolvimentos subseqüentes nas suas várias frentes de atuação. A ênfase, no entanto, considerando-se os objetivos desta publicação, recai sobre o componente de recursos humanos, sem deixar de assinalar as suas conexões com as demais áreas de atuação da cooperação e o contexto institucional da saúde em seus termos mais gerais. O capítulo se encerra com a conjuntura imediatamente posterior à realização da VIII Conferência Nacional de Saúde e da Conferência Nacional de Recursos Humanos. Estes episódios, entre outros, pertinentes ao arranjo institucional e à sua organização e funcionamento, demarcam o fim do ciclo pioneiro da Cooperação Técnica em RH, nos termos em que esta havia se iniciado dez anos antes.

Um quinto capítulo, que encerra o estudo histórico, discute esta reconfiguração da Cooperação Técnica e avança pelos seus principais desdobramentos no domínio dos recursos humanos. Pretende-se, desta forma, nas 
últimas páginas, esboçar uma análise sobre o que seria o legado da cooperação técnica Opas-Brasil, no momento em que a moderna reforma sanitária brasileira adentrava uma nova era, institucionalizando-se como política de Estado, nos marcos da promulgação da Constituição de 1988 e da instituição do Sistema Único de Saúde.

$\mathrm{Na}$ segunda parte da obra, apresentamos, a partir de temas selecionados, trechos editados de depoimentos concedidos pelos componentes da equipe pioneira do Grupo Técnico Central do Ppreps, e pelo então Diretor de Desenvolvimento de Recursos Humanos da Opas, em Washington. Assim, reunindo os pronunciamentos de Alberto Pellegrini, Carlyle Guerra de Macedo, Cesar Vieira, Danilo Garcia, Izabel dos Santos, José Paranaguá de Santana, José Roberto Ferreira e Roberto Nogueira, pretende-se que uma parte da memória viva da Cooperação Técnica Opas-Brasil se torne mais bem compartilhada, como experiência singular no campo dos recursos humanos em saúde no Brasil. Para uma melhor localização do leitor nas trajetórias pessoais de cada um destes personagens, a seção é finalizada com uma coleção de resenhas biográficas dos depoentes.

Estes depoimentos, evidentemente, não esgotam todas as possibilidades. Vários outros personagens de atuação importante - e mesmo decisiva para o desenvolvimento da cooperação em seu conjunto e, em particular, dos seus vários programas, poderiam ter sido entrevistados. Ao estabelecer como um primeiro universo de depoentes os brasileiros diretamente envolvidos nos movimentos iniciais da Cooperação Técnica, buscou-se algo como abrir um caminho; empreender uma primeira investida que, esperamos, se renove no futuro, em múltiplas direções e pelas mãos de vários investigadores.

Além dos testemunhos dos pioneiros, foram utilizados, como fontes textuais de pesquisa, documentos oficiais da Opas - principalmente projetos e relatórios -, publicações científicas, documentos legislativos, pareceres, trabalhos de congressos, entre outros. Integram os acervos da Biblioteca da Escola Nacional de Saúde Pública Sérgio Arouca (Ensp/Fiocruz); do Centro de Documentação e da Biblioteca da Sede da Opas em Brasília (Opas-Brasil); do Fundo Presidência da Fiocruz, do Fundo Escola Nacional de Saúde Pública e da Coleção Políticas Prioritárias do Inamps (1985-1988), constantes do acervo do Departamento de Arquivo e Documentação da Casa de Oswaldo Cruz (COC/Fiocruz); além de documentação doada por alguns dos personagens entrevistados. O Boletín de la Oficina Sanitaria Panamericana e a Revista Educación Médica y Salud também foram fontes preciosas. 
Esta publicação é um dos resultados previstos no programa de trabalho 2006-2007 do Observatório História e Saúde, coordenado pela Casa de Oswaldo Cruz (COC/Fiocruz), e que integra a Rede Observatório de Recursos Humanos (ObservaRH), conduzida no Brasil pela Opas e pela Secretaria de Gestão do Trabalho e da Educação na Saúde (Segetes), do Ministério da Saúde. A presença da história e da memória como objetos centrais de uma das estações de trabalho desta rede resulta da expectativa de poder explorar e estimular o potencial da história como conhecimento pertinente aos processos de formulação e avaliação de políticas no domínio dos recursos humanos em saúde. O presente trabalho é um esforço nesta orientação e não teria sido possível sem as idéias precursoras de Nísia Trindade Lima e de José Paranaguá de Santana, a acolhida e o apoio direto do Ministério da Saúde nas figuras de Pedro Miguel dos Santos Neto, Maria Luiza Jaeger e Francisco Eduardo de Campos.

Este trabalho contou com o apoio do Observatório de Recursos Humanos do Núcleo de Saúde Coletiva, da Universidade Federal do Rio Grande do Norte, na pessoa de Janete Lima de Castro, nossa co-autora no capítulo 4. Janete, Gilberto Hochman e Regina Celie Marques dividiram conosco a elaboração dos Diálogos com os Pioneiros, na Parte 2. Gilberto e José Paranaguá de Santana, como nossos leitores críticos, examinaram e anotaram as primeiras versões. Compartilhamos com todos eles os possíveis méritos deste trabalho. A presença solidária de Paula Xavier dos Santos e Regina Marques, à frente das atividades de informação e documentação do Observatório História e Saúde, foi também inestimável, assim como o auxílio dedicado de Fernanda Nahuz, do Centro de Documentação da Opas-Brasil, e de Alex dos Santos da Silveira.

Por fim, cabe mencionar que a Rede ObservaRH reúne parte significativa dos herdeiros do legado da Cooperação Técnica Opas-Brasil em RH. Da mesma forma os Núcleos de Saúde Coletiva espalhados pelo Brasil. Outra parte está, com certeza, na Rede de Escolas Técnicas do SUS, na Rede Unida e onde mais houver uma equipe dedicada ao tema. Trata-se mesmo de uma jovem tradição que se refunda todos dias, quanto mais se vive, trabalha, experimenta e apreende no terreno crítico dos recursos humanos em saúde. É uma satisfação poder, como historiadores, visitar a história dos pioneiros desta tradição e de toda esta gente imprescindível. Imprescindível como o são o trabalho e o trabalhador da saúde, assim como a militância de boa cepa. 
Parte I. Estudo Histórico 


\section{Traços de um Contexto: saúde INTERNACIONAL, POLÍTICAS NACIONAIS E RECURSOS HUMANOS}

Os principais eventos e processos descritos e discutidos aqui tiveram início em meados da década de 1970 e uma trajetória que se alonga até finais da década seguinte. Entre os atores institucionais em cena figuraram uma organização intergovernamental da região das Américas, a Organização PanAmericana da Saúde (Opas), os ministérios da Saúde, da Educação e Cultura, da Previdência e Assistência Social, além de outras agências federais brasileiras. Fizeram-se igualmente presentes os poderes executivos nos estados, em especial as secretarias estaduais de Saúde e Educação; segmentos das classes políticas, dos seus partidos legais e ilegais; além de organizações de uma sociedade civil que, no Brasil, se encontrava em franco processo de reconstrução, superados os anos mais duros da repressão política.

Mesmo que se restringindo a algumas poucas e rápidas pinceladas, esboçar o contexto histórico e institucional em que se estabeleceu a Cooperação Técnica Opas-Brasil em Recursos Humanos sugere uma abordagem que dê conta de duas dimensões. A primeira diz respeito ao âmbito internacional e interamericano, procurando, portanto, inscrever o objeto no interior da trajetória da Opas como organização internacional de saúde nas Américas, da sua agenda e das suas estratégias no período considerado. Diz respeito, também, a alguns processos de alcance global - como as crises do petróleo e da dívida externa - que provocaram impactos na formulação de políticas no âmbito dos organismos internacionais e na própria percepção acerca do papel do Estado como prestador de serviços sociais e promotor do desenvolvimento. 
A segunda dimensão se refere ao contexto nacional, naquele intervalo de tempo. Um contexto política, econômica e socialmente denso, revestido de considerável grau de dramaticidade, como o era o ambiente da reconstrução democrática brasileira. No terreno das políticas sociais e em particular a da saúde, o período assinala a vigência e crise dos planos nacionais de desenvolvimento; a elaboração e tentativa de implantação de um Sistema Nacional de Saúde e de programas destinados a realizar a ampliação da cobertura da atenção médica; os movimentos de crítica teórica sobre os determinantes da saúde e da doença, assim como de ação política no sentido da reforma de sistemas e serviços de saúde. Assinala também os primeiros momentos da constituição do Sistema Único de Saúde, como a forma brasileira de estabelecer, no último quarto do século XX, uma nova institucionalidade para a saúde.

Estas duas dimensões, que se interpenetram, serão abordadas aqui em dois segmentos distintos. Espera-se que as principais áreas de intercessão fundamentais para o enquadramento contextual que se pretende - se tornem claras ao longo do próprio desenvolvimento do capítulo. Em ambos segmentos, pretende-se explicitar de que maneira o temas dos recursos humanos e do trabalho em saúde se localizam e dialogam com os componentes do contexto. A Cooperação Técnica em Recursos Humanos entre o governo brasileiro e a Opas é, ela mesma, parte integrante destes diálogos.

\section{O CONTEXTO INTERNACIONAL}

Como designar a década de 1970 em termos globais? Uma das possibilidades talvez seja indicar que ela encerra um ciclo, ou vários ciclos mais ou menos articulados. Este período registrou, sem dúvida, o fim do ciclo de crescimento econômico que se iniciara ao final da segunda guerra mundial e que foi relativamente difundido por todo o planeta. Ele pôs fim, no ocidente capitalista, a um relativo consenso acerca dos papéis desempenhados pelo Estado como ente produtivo, promotor do desenvolvimento e da solidariedade social, neste caso principalmente ao prover diretamente serviços considerados básicos, entre estes a previdência social, a educação e a saúde.

Ao seu final tem início um período de estagnação econômica, anunciado na primeira crise do petróleo, em 1973, consolidado no segundo choque, de 1979, e na crise da dívida dos países em desenvolvimento. Ao fim dos anos 70 teve início, também, o movimento ascendente das teorias do Estado mínimo, que, em larga medida, dominariam os termos do debate nas duas décadas seguintes. 
A década encerra também o período clássico de vigência do desenvolvimento em todo o seu vigor. Desenvolvimento, tal como o concebe Arturo Escobar (1995), como domínio tanto discursivo, quanto concreto/prático, porque expresso em ações, e que a partir do pós-segunda guerra definiu os termos pelos quais se dariam as relações entre sociedades capitalistas centrais e o chamado mundo periférico. Nele, ciência e técnica tornaram-se condição e modo de expressão de um aparato de conhecimentos e práticas que moldaria o mundo não euro-americano à feição de um ocidente moderno que avançava em seu movimento de mundialização. Atuar de modo cientificamente embasado e promover a introdução da tecnologia nos vários domínios da vida social significava, quase que sem mediações, ser civilizado e moderno. Neste movimento, as organizações internacionais e as iniciativas de assistência/ cooperação técnica internacional sem dúvida desempenharam papel decisivo.

Quanto aos acontecimentos políticos do período os enunciados genéricos são mais difíceis de serem feitos. De toda forma, é possível dizer que na América Latina, sobretudo, a década de 1970 assinala a última voga de implantação de regimes autoritários à direita. De outro lado, as ditaduras mais longevas começavam então a dar nítidos sinais de esgotamento. A ditadura brasileira pertencia a este último grupo.

Nos anos 70, a Opas vivia também, em determinado sentido, os anos finais de um ciclo: de uma trajetória de expansão de suas estruturas operacionais como organização internacional funcional de saúde nas Américas. ${ }^{5}$ Com efeito, uma vez superadas as difíceis negociações em torno da sua permanência como organização regional autônoma e reconhecida como tal frente à recém criada Organização Mundial da Saúde (1948), a Opas emergiu do pós-guerra, sob a direção do norte-americano Fred Soper, de 1947 a 1959, como uma entidade institucionalmente legitimada, financeiramente saudável e em franco processo de expansão ${ }^{6}$. De fato, enquanto se desenrolava o propalado ciclo

5 Organização internacional funcional é aquela dedicada a áreas temáticas específicas como podem ser a da Saúde, de Comércio Exterior, de Energia Nuclear, entre outras. Para uma categorização das organizações internacionais, bem como para uma introdução ao seu desenvolvimento histórico, ver Herz \& Hoffmann, 2004.

6 A criação da OMS e o debate sobre o destino da Opas estão descritos em Cueto (2004, p.74-79), OPS (1992: 41-47) e Siddiqi (1995: 53-86). Para uma visão panorâmica da história da Opas, ver também Lima (2002). Parte da história institucional da Opas na segunda metade do século XX foi desenvolvida também em Pires-Alves, 2005: 22-26) e fração deste trabalho foi retomada na elaboração deste capítulo. A saúde financeira da organização no final dos anos 40, em que pesem restrições nas contribuições por parte dos EUA, deveu-se principalmente à capacidade de Fred Soper em mobilizar prestígio pessoal para a obtenção de recursos complementares. 
dourado da prosperidade capitalista do pós-segunda guerra, a Opas aumentou seu orçamento e estrutura, decidindo por dividir o continente em sete zonas de atuação, cada uma com um escritório local ${ }^{7}$, e instituir centros regionais especializados, em um movimento que avançaria pelos anos 60 e 70, já na gestão do chileno Abraham Horwitz, entre 1959 e 1975 . Esta expansão dos seus meios operacionais diretos, "em campos específicos que transcendem o alcance dos países individualmente", envolveu quase sempre uma estratégia de celebração de acordos e convênios com outros organismos intergovernamentais, instituições internacionais de fomento e os próprios Estados da região, na época razoavelmente receptivos a uma expansão dos seus gastos?. Ao se aproximar a década de 80 , a Opas vai paulatinamente passar a preferir estabelecer redes cooperativas entre instituições, baseadas na capacidade já instalada nos países, aos custosos encargos resultantes da montagem e manutenção de centros próprios.

De toda forma, quando a Aliança para o Progresso trouxe os temas sociais para o primeiro plano da cooperação internacional nas Américas, a Opas operou como instância técnica do sistema interamericano e espaço de expressão das comunidades especializadas da saúde. Na Reunião Extraordinária do Conselho Interamericano Econômico e Social em Nível Ministerial (Cies-OEA), realizada entre 5 e 17 de agosto de 1961, na cidade uruguaia de Punta del Este, um evento que reuniu delegações de alto nível de todos os

7 As zonas, sedes e áreas de cobertura foram as seguintes: Zona I (Washington), para Canadá, EUA e territórios não autônomos; Zona II (México), México, Cuba, República Dominicana. Dominicana, Haiti; Zona III (C. da Guatemala), Guatemala, Peru, Honduras, Costa Rica, El Salvador, Nicarágua, Panamá; Zona IV (Lima), Bolívia, Peru, Venezuela, Colômbia, Equador; Zona V (Rio de Janeiro), Brasil; e Zona VI (Buenos Aires), Argentina, Uruguai, Chile, Paraguai. (Cueto, 2004).

8 Foram os seguintes os centros pan-americanos estabelecidos pela Opas e suas sedes e anos de instalação: Instituto de Nutrição da América Central e Panamá, (Incap), Cidade da Guatemala 1946; Centro Pan-americano de Febre Aftosa (Panaftosa), Rio de Janeiro, 1951; Centro Pan-americano de Zoonoses (Cepanzo), Buenos Aires, 1956; Biblioteca Regional de Medicina, Bireme, São Paulo, 1967; Centro Latino-Americano de Administração Médica (Clam), Buenos Aires, 1967; Instituto de Alimentação e Nutrição do Caribe (IANC), Kingston, 1967; Centro Pan-Americano de Planificação da Saúde, Santiago, 1968; Centro Pan-americano de Engenharia Sanitária e Ciências do Ambiente (Cepis), Lima, 1968; Centro de Perinatologia e Desenvolvimento Humano (Clap), Montevidéu, 1970; Centro Latino-Americano de Tecnologia Educacional em Saúde, (Clates), Rio de Janeiro, 1972; Clates - México, Cidade do México, 1973; Centro de Epidemiologia do Caribe (Carec), Porto Espanha, Trinidad e Tobago,1974; e o Centro Pan-Americano de Ecologia Humana e Saúde (ECO), Cidade do México, 1974 (Cueto, 2004 e Opas, 2002) Um ciclo de desativações se inicia em 1976, começando pelo CLAM. O Instituto Pan-Americano de Proteção de Alimentos e Zoonoses (Inppaz) foi criado em 1991, em Martinez, Argentina, sendo uma espécie de centro temporão (Opas, 2002).

9 A citação é atribuída a Fred Soper, então diretor da Opas, em OPS (1992:512), sem indicação de fonte. 
países americanos, com grupos de especialistas e observadores convidados, Abraham Horwitz, diretor da Opas, apresentou dois trabalhos ${ }^{10}$ (Horwitz, 1961a: 379-382; 1961b: 387-388). Seus temas se prenderam à afirmação da centralidade da saúde como condição para o desenvolvimento, à prescrição de ações de caráter imediato e à identificação de temas de atenção estratégica de longo prazo e aos meios adequados para abordá-los. Horwitz, nestas intervenções, renovava as proposições presentes em "Hechos sobre Problemas de Salud: la salud en relación con el progresso social y el desarrollo económico de las Américas", um documento de referência elaborado pela Opas para aquela reunião (OPS, 1961). Em sua maior parte, os seus princípios, temas e eixos organizadores foram incorporados ao Plano Decenal de Saúde Pública da Aliança para o Progresso, um dos documentos aprovados ao final do encontro (OEA, 1961).

Afirmando as relações recíprocas entre saúde e desenvolvimento e a necessidade de promoção coordenada do desenvolvimento econômico e social mediante a elaboração e implementação de planos nacionais de desenvolvimento, o documento prescrevia a preparação de planos nacionais de longo prazo, identificava os problemas e metas prioritárias imediatas e definiu os meios de atuação preferenciais. Os problemas e metas demarcados diziam respeito à oferta de água potável e à provisão de serviços de esgotamento; à mortalidade infantil; ao controle de doenças transmissíveis, o que incluía a erradicação da malária e da varíola; à alimentação e nutrição de populações desfavorecidas; e à ampliação, organização e administração da rede de assistência à saúde.

Os meios preferenciais ficavam definidos como sendo o planejamento e avaliação de ações, o que implicava a instituição de unidades especializadas nos ministérios e a gestão adequada de estatísticas vitais e sanitárias; a administração coordenada dos serviços de saúde, com a articulação dos âmbitos nacional e local, assim como a integração da prevenção com a assistência curativa; e a ênfase na formação e capacitação dos recursos humanos, o que implicava "estabelecer quantitativos ideais de profissionais, técnicos e auxiliares, promover a capacitação em serviço e ampliar a oferta de cursos formativos (...)." (OEA, 1961: 490-491).

\footnotetext{
10 A delegação brasileira foi chefiada por Clemente Mariani Bittencourt, à época Ministro da Fazenda do governo de Jânio Quadros. Este renunciaria uma semana depois do fim da reunião. A delegação cubana foi chefiada por Ernesto Che Guevara.
} 
Em conseqüência de uma resolução complementar da reunião uruguaia, a Opas organizou em Washington, entre 15 e 20 de abril de 1963, uma Reunião de Ministros da Saúde dos países signatários da Carta da Punta del Este. Precedida de um conjunto de reuniões preparatórias e da realização da XVI Conferência Sanitária Pan-Americana, este encontro teve por objetivos aprofundar a análise comum dos problemas de saúde e estabelecer uma agenda objetiva a partir dos enunciados do Plano Decenal. Seu Informe Final, deste modo, repercutiu e procurou imprimir materialidade prática às prescrições da Reunião Extraordinária de Punta del Este e aos seus desdobramentos imediatos. As análises e recomendações da reunião se organizaram em torno do que seriam os quatro meios ou instrumentos preferenciais para a proteção, promoção e recuperação da saúde: o planejamento, a administração dos serviços, a investigação científica e a formação dos recursos humanos (OPS, 1963: 1-49).

A idéia de planejamento, como forma de proceder a uma mobilização programada dos recursos disponíveis, com o fito do alcance de objetivos e metas definidos segundo determinados diagnósticos, afirmava no terreno da saúde a necessidade da pesquisa epidemiológica e da informação estatística, como requisitos para a fixação de prioridades. Da mesma forma, prescrevia o desenvolvimento de metodologias para o que deveria ser um "planejamento integral do desenvolvimento econômico e do bem-estar". Nos marcos desta pretensão totalizante, a planificação da saúde deveria ser parte integrada aos planos nacionais de desenvolvimento, estes últimos uma precondição para que um país pudesse se candidatar à ajuda interamericana segundo os termos da Aliança para o Progresso. Recomendava-se o estabelecimento, em cada ministério da Saúde, de unidades especializadas nas metodologias de planejamento e avaliação de programas, na reunião sistemática de informações vitais, sanitárias e hospitalares, assim como para a formação e treinamento de pessoal para estas atividades específicas (OPS, 1963).

Com o objetivo de desenvolver metodologias e auxiliar os governos da região nas tarefas de planejamento da saúde, a Opas instituiu uma unidade especializada na sua sede em Washington, em 1961. O desenvolvimento de projetos específicos, com o concurso de especialistas contratados, suscitou a abertura de frentes de cooperação com instituições latino-americanas, entre estas o Centro de Estudos do Desenvolvimento Econômico Social (Cendes) e a Escola de Saúde Pública, ambos da Venezuela. O trabalho com estas instituições resultou na elaboração de um método de planejamento em saúde que 
ficou conhecido pela sigla Cendes-OPS, com ampla difusão na região das Américas. Sua primeira versão veio à luz em $1962^{11}$.

A experiência venezuelana permitiu à Opas promover cursos destinados à formação de planejadores da saúde em escala regional, em conjunto com o Instituto Latino-Americano e do Caribe de Planejamento Econômico e Social (Ilpes), um organismo da Comissão Econômica para a América Latina - Cepal/ONU, localizado em Santiago, Chile. Esta conexão Caracas Santiago e a colaboração com o Ilpes e a Cepal ensejaram a criação de um Programa de Planejamento da Saúde, em 1968 formalizado como um novo centro especializado da Opas: o Centro Pan-Americano de Planejamento da Saúde, que entrou em operação efetiva em 1970, nas dependências do Ilpes. Constituía-se neste processo uma escola de planejamento em saúde que teria vasta penetração no continente (OPS, 1972, p. 1-2; Paiva, 2005).

Em larga medida, o tratamento dado pela Opas aos temas dos recursos humanos em saúde nas décadas de 1960 e 1970 seria informado pela inscrição destes como parte dos planos de saúde de alcance regional e nacional e como parte dos objetos do planejamento como ferramenta preferencial de intervenção. Vale salientar, todavia, ainda que de modo ligeiro, que as posições doutrinárias em torno do planejamento e das suas técnicas vivenciavam também uma transição no período em questão. Já ao final da década de 1960, o método Cendes-OPS seria gradativamente abandonado, tendo em vista seu caráter normativo e tecnocrático, em favor das formulações orientadas para o planejamento estratégico e as suas variações ${ }^{12}$.

Este movimento, como todo o resto, correspondia a uma transição entre perspectivas na saúde internacional, inclusive no contexto latino-americano. Em linhas gerais, a gestão de Abraham Horwitz como diretor da Opas, compreendida entre 1958 e 1975, foi referida como sendo a da afirmação do direito à saúde (OPS, 1992). Ela compreendeu o enunciado do aumento da cobertura dos serviços de saúde como uma idéia-força capaz de organizar as pautas institucionais, ao mesmo tempo em que registra o aumento da crítica às intervenções massivas de tipo vertical, orientadas por doença, e à medicina curativa centrada na organização hospitalar e no uso crescente de tecnologias complexas. Correspondeu à crescente popularidade das abordagens ditas in-

11 A versão final e de circulação continental é de 1965 (Ahumada et al., 1965).

12 Para uma análise crítica do planejamento em saúde no período, ver Giovanella, 1989, 1992 e 2006. Uma abordagem histórica do planejamento em saúde está em Barrancos \& Mendes, 2006. 
tegrais e das experiências de medicina simplificada empreendidas em países em desenvolvimento, entre as quais aquela que envolveu a utilização dos Médicos de Pés Descalços na República Popular da China ${ }^{13}$. Este trânsito culminou, em termos globais, com o estabelecimento, em 1977, da meta de Saúde para Todos no Ano 2000 e, no ano seguinte, da atenção primária como a estratégia central para alcançá-la (Cueto, 2004).

Em inícios dos anos 60 a Opas já mantinha a pelo menos uma década uma atenção institucional para as questões de recursos humanos, em particular no que concerne ao ensino geral de medicina e da medicina preventiva. O próprio Abraham Horwitz, em artigo de 1962, indicava que nesta área a época seria de "profundas transformações" ocorrendo "progressivamente desde há vinte anos" e seria especialmente bem representada por uma seqüência de eventos iniciada em 1951, com o Congresso Pan-Americano de Educação Médica, realizado em Lima, Peru; passando pela Conferência de Colorado Springs sobre o Ensino de Medicina Preventiva, de 1952; e terminando com a Segunda Conferência Mundial de Educação Médica, de 1959, realizada em Chicago, sob os auspícios da World Medical Association ${ }^{14}$ (Horwitz, 1962: 281, 286). São igual e freqüentemente citados, como eventos fundamentais, a realização dos seminários de medicina preventiva realizados em Viña del Mar, Chile, em 1955, e em Tehuacán, México, no ano seguinte. Em certa medida o próprio campo dos recursos humanos em saúde refere a Opas como parte importante da sua própria constituição, ao participar e promover a realização de reuniões com o propósito de empreender uma revisão do ensino médico no continente (Nunes, 2000; Ferreira, 2005; Santana, 2005).

Já a partir Conferência de Punta del Este, e da subseqüente Reunião de Ministros da Saúde dos Países Americanos (1963), às preocupações com o ensino de medicina e o quantitativo de profissionais de nível superior disponíveis nos países somavam-se enunciados relativos aos contingentes daqueles então designados genericamente como trabalhadores auxiliares. No Plano Decenal de Saúde Pública, apontava-se para necessidade de atribuir importância programática à formação e capacitação de profissionais e auxiliares, o que incluiria determinar o número necessário em cada categoria; capacitar em ser-

13 Para um exemplo da repercussão da experiência chinesa no ocidente, ver Lee (1974).

14 A série de eventos mencionados por Horwitz inclui também: Conferência de Faculdades LatinoAmericanas de Medicina, Cidade do México, 1957; Reunião Científica da Associação Latino-Americana de Ciências Fisiológicas, Punta del Este, 1957; Seminário de Ensino de Medicina Interna, Manizales, Colômbia, 1959; e os I e II Seminários de Educação Médica da Colômbia, respectivamente 1955 e 1957, Cali e Medelin (Horwitz, 1962). 
viço os trabalhadores atuais e formar outros nos quantitativos necessários; e ainda ampliar ou criar as instituições educativas requeridas para tal fim (Opas, 1961). No Informe Final da Reunião de Ministros da Saúde, de 1963, o tema foi desenvolvido, tornando explícito o diagnóstico geral que informava tal preocupação (OPS, 1963).

Registrava-se uma carência de pessoal em todas as profissões de saúde, em especial de enfermeiros e engenheiros sanitários ${ }^{15}$. Além desta insuficiência numérica, identificava-se uma inadequada distribuição geográfica destes profissionais, em especial dos médicos, concentrados nas capitais e, nestas, nos bairros mais abastados. Os serviços de enfermaria eram executados, geralmente, por auxiliares sem nenhum tipo de capacitação, sendo, portanto, urgente um incremento na formação de enfermeiras e na sua capacitação para o exercício de atividades de supervisão. Preconizava-se a necessidade de incrementar a formação de técnicos auxiliares tendo por base um ensino médio de melhor qualidade. Ressaltando o papel do médico como liderança das equipes de saúde, o documento reclamava um maior empenho dos governos nacionais no sentido de imprimir maior qualidade às escolas médicas. Preconizava-se uma revisão dos programas de ensino e uma maior aproximação entre as instituições formadoras e aquelas encarregadas da prestação de serviços com vistas ao estabelecimento de hospitais-escola e laboratórios de medicina comunitária urbana e rural (OPS, 1963).

Era este o diagnóstico mais geral. Todavia, no capítulo das recomendações, quando medidas mais imediatas foram preconizadas, é possível perceber que a principal atenção dos ministros da saúde era dirigida para a escola médica e a formação destes profissionais. Com efeito, a década de sessenta e os primeiros anos setenta registrariam em todo o continente um aumento quase explosivo do número de faculdades de medicina e de médicos titulados anualmente. O caso brasileiro é exemplar deste crescimento exponencial (Opas, 1973; Pierantoni, França \& Varela, 2006: 39-40).

Quando os ministros do continente se reuniram para estabelecer aquele que seria o II Plano Decenal de Saúde, de 1972, o tema dos recursos humanos já assumiria uma nova configuração. Entrementes, um grupo de médicos e especialistas, a partir da Opas, não só realizaram um profundo balanço do duplo movimento de expansão e reforma do ensino médico na América La-

15 Nos documentos do período, a expressão profissões de saúde era utilizada exclusivamente para designar as habilitações de nível superior, uma distinção mais tarde praticamente abandonada. Todavia, foi mantido este uso neste trabalho, tornando a narrativa mais próxima do tempo narrado. 
tina, como empreenderam uma atualização da sua agenda programática com base em uma ativa militância ${ }^{16}$. Ao mesmo tempo, organizações internacionais, entre elas a Fundação W.K. Kellogg e a Federação Pan-Americana de Associações de Faculdades (Escolas) de Medicina, davam suporte a um crescente movimento de medicina comunitária (Chaves, 1994: 6).

O II Plano Decenal de Saúde para as Américas foi firmado ao final da III Reunião Especial dos Ministros da Saúde das Américas, realizada em 1972, em Santiago, Chile, durante o Governo de Salvador Allende. Neste plano, sob o signo da expansão da cobertura dos serviços de saúde por meio da estratégia da atenção básica, o componente de recursos humanos mereceu considerável destaque e uma orientação marcadamente diferente em alguns aspectos importantes em relação ao plano precedente.

O problema, em larga medida, deixara de ser a quantidade de médicos disponíveis. Recomendava-se a valorização do médico generalista como resposta à tendência de uma crescente e cada vez mais precoce especialização, ao mesmo em que se renovavam as preocupações com a sua distribuição no território. O recurso ao auxiliar de nível médio é enfatizado como meio de se alcançar uma efetiva ampliação da cobertura dos cuidados médicos e, ao mesmo tempo, aumentar a própria produtividade do trabalho médico. Assinalava-se a necessidade de formação de odontólogos, nutricionistas, farmacêuticos e médicos veterinários e destacava-se o caráter multiprofissional das equipes de saúde. De um ponto de vista doutrinário, o documento reafirmava o compromisso com uma concepção integral do fenômeno saúde-doença; com a abordagem multidisciplinar para o conhecimento destes fenômenos e para as ações de prevenção e cura; e com a integração docente-assistencial como forma de articular os processo formativos e as ações de atenção à saúde, tanto de profissionais de nível superior, quanto de técnicos e auxiliares (Opas, 1972: 17-21) ${ }^{17}$.

16 Entre os principais personagens deste grupo figuravam: Ramón Villareal, Juan César García e Jorge Andrade. Ver Garcia, 1972, e Andrade, 1979.

17 Esta transição entre os temas que dominavam a pauta dos recursos humanos em saúde no contexto latino-americano era parte de um debate que também se manifestava globalmente. É possível identificar uma sensível correspondência entre a evolução dos debates no âmbito da Opas com aquela verificada nos processos de formulação de políticas no contexto da Organização Mundial da Saúde, ao longo entre 1960 e 1980. Como assinalam Fülöp \& Roemer (1982), em um estudo de fôlego sobre as políticas de desenvolvimento de recursos humanos nos primeiros 40 anos da OMS, os debates no âmbito das Assembléias Mundiais de Saúde registraram, nas décadas de 1970 e 1980, paulatino e consistente aumento da presença relativa de temas como o treinamento de pessoal auxiliar; treinamento para a atenção primária; abordagem por meio de equipes de saúde; e integração entre formação de pessoal e serviços de saúde. Um tema a ser investigado diz respeito a aquilatar até que ponto a Opas e os delegados latino-americanos são protagonistas desta reconfiguração. 
Como assinala Schraiber (1989:121), àquela altura norteavam os debates sobre a educação médica os imperativos de uma expansão da atenção médica presidida pela idéia da existência de necessidades sociais prioritárias, assim como de cuidados prioritários, básicos e integrais a serem ofertados às populações, segundo a freqüência de agravos e patologias, no interior de uma concepção hierarquizada da prestação de cuidados, segundo a sua complexidade (primária ou básica; secundária; terciária).

Tratava-se assim de, prioritariamente, promover a formação de um profissional médico habilitado a prover um tipo de cuidado primário, fundamental, orientado tanto pelas exigências de integralidade, quanto de adequação ao contexto nosológico. Isto significava, também, preparar profissionais, em novos termos, tanto para a prestação de serviços como para a sua própria organização. Os principais obstáculos identificados eram, novamente, a fragmentação dos conhecimentos e práticas; a especialização voltada para a doença rara, cientificamente atraente, mas de baixa significação social; e o cuidado com base em tecnologias custosas. A respeito deste último aspecto, prescreviase um processo de simplificação tecnológica com vistas à obtenção das chamadas tecnologias simples e apropriadas ao seu contexto de aplicação (Schraiber, 1989:122).

As correntes do pensamento médico mais próximas a estas preocupações seriam, ainda segundo Schraiber, a Medicina Generalista, a Medicina Comunitária e a Integração Docente-Assistencial - IDA (1989: 106). Sobretudo a IDA era uma das formulações mais presentes no pensamento médico educacional crítico na segunda metade da década de 1970, com ampla expressão a partir da Opas. Ao final da década, por exemplo, o Informe Final do Grupo de Trabalho sobre Requisitos Mínimos para a Criação de Escolas de Medicina, publicado em Educación Médica y Salud (1979), recomendava a IDA como uma das estratégias mais promissoras na medida em que pretendia, no âmbito de processos de regionalização, uma profunda articulação entre todos os segmentos da escola médica e os vários níveis de atenção, a partir da idéia de regionalização (Almeida, 2001: 46).

O próprio hospital-escola, peça chave da arquitetura curricular em vigor em várias escolas, era nitidamente secundarizado em termos de importância como espaço docente. Seu perfil excessivamente acadêmico, orientado para a pesquisa dos quadros patológicos raros, o diagnóstico e a terapêutica tecnologicamente intensivas eram considerados uma distorção. Para os defensores da IDA, todos os lugares e níveis de prestação de serviço deveriam ser 
considerados como espaços docentes e o próprio hospital-escola reconfigurado à semelhança das unidades regulares do sistema de saúde (Schraiber, 1989: 124; Ferreira, 1976: 140-149).

Principalmente a IDA, mas também as demais correntes sensíveis às questões da expansão da cobertura da atenção à saúde, produziram uma atualização do tema da integração, na perspectiva de uma saúde pensada prioritariamente em termos coletivos. Pretendia-se integrar radicalmente a formação e capacitação de recursos humanos às prioridades objetivas dos serviços de saúde, percebidas estas como projeção das necessidades sociais mais amplas rumo ao desenvolvimento.

\section{O Contexto Brasileiro}

Durante os anos 1970, o Brasil vivenciaria o ápice e a decadência do ciclo de crescimento acelerado, comumente referido como do milagre econômico. Ao final da década, o período de altas taxas de crescimento havia se encerrado, ainda que sua sobrevida tenha sido prolongada com base em uma arriscada política de endividamento externo. Em 1980, iniciava-se o ajuste econômico que imporia anos de depressão entre 1981 e 1983 e uma década de desempenho pífio, a chamada década perdida.

Todavia, ainda durante os anos de crescimento econômico de meados da década de 1970, as bases políticas do regime já davam sinais de enfraquecimento. Mesmo em um contexto de liberdades políticas especialmente restritas, as oposições representadas no Movimento Democrático Brasileiro haviam imposto revezes eleitorais ao regime já no pleito de 1974, ameaçando o frágil equilíbrio entre as correntes mais autoritárias do exército e a estratégia de democracia relativa e abertura controlada ${ }^{18}$.

Foi neste quadro político e econômico que o governo Geisel lançou o II Plano Nacional de Desenvolvimento. No terreno estritamente econômico, ainda informado pelos anos de euforia e pela idéia de um país-potência em construção, o plano pretendia aprofundar a política de substituição de importações, concentrando sua atenção sobre a produção de insumos básicos e de bens de capital ao invés da mera substituição de bens de consumo. Suas chances de sucesso neste terreno seriam reduzidas, uma vez que combinava os vícios

18 Para uma visão abrangente sobre este período da história brasileira, ver Fausto (2000) - especialmente a parte IX, O Regime Militar (1964-1985). Ver também Skidmore, 2004. 
do gigantismo das metas com uma crise internacional em gestação (Lessa, 1998). O plano, porém, introduziu como inovação todo um capítulo destinado às políticas sociais, cujo sentido era, segundo algumas análises, restaurar as já desgastadas bases de legitimidade social do regime (Escorel, 1998: 43). Segundo outras avaliações, o II PND refletia o grau de relativa autonomia com que, naquela conjuntura, núcleos de autoridade da tecnoburocracia governamental, com base estritamente em princípios de racionalidade técnica, concebiam planos e projetos de desenvolvimento a partir do Estado ${ }^{19}$.

De toda forma, o II Plano Nacional de Desenvolvimento pretendia alcançar a coordenação entre os ministérios que compunham a chamada área social, a partir da constituição do Conselho de Desenvolvimento Social e do estabelecimento do "orçamento social", resultado da soma dos recursos de cada pasta e de uma pretendida integração programática. Três áreas de atuação do governo funcionariam como eixos organizadores: o Programa de Desenvolvimento Social Urbano, voltado para a infra-estrutura de transportes de massa, iluminação pública, entre outros aspectos; a Integração Social compreendendo, sobretudo, as políticas de suplementação de renda e habitacional; e, principalmente, o Programa de Valorização de Recursos Humanos, que reunia todos aqueles componentes explicitamente considerados como de alguma forma associados à capacidade produtiva do trabalhador: educação, saúde, assistência médica, nutrição e treinamento profissional (Velloso, 1975). Desta forma, o plano, pelo menos no terreno da retórica, conferia alguma centralidade estratégica ao tema de recursos humanos, ainda que considerados sob um viés acentuadamente econômico. Também no âmbito do discurso, enfatizava o tema da integração entre as pastas ministeriais diretamente envolvidas com a temática da saúde, ao mesmo tempo em que delimitava formalmente as áreas de atuação de cada ministério - uma dicotomia que, aliás, seria uma das questões recorrentes nos debates sobre serviços de saúde no Brasil até criação do Sistema Único de Saúde, cerca de 15 anos depois.

Foi neste contexto que o regime instituiu, por meio da Lei 6.229, de julho de 1975, o Sistema Nacional de Saúde. Um sistema que no mês seguinte foi debatido, quanto à sua operacionalização, no âmbito da V Conferência Nacional de Saúde, realizada em Brasília. A literatura que analisa este período

19 Ambas as posições estão representadas na literatura de saúde que refere o período. Escorel (1998) é um exemplo do primeiro caso. Um artigo assinado coletivamente pelo Nerhus-Ensp-Fiocruz em PEC-Ensp/Abrasco (1987), baseando-se na tese de doutoramento de Carlos Lessa, de 1978, publicada em Lessa (1998), exemplifica um uso da segunda interpretação. 
identifica na proposição deste sistema de saúde uma iniciativa que termina por consolidar, nos ministérios da Saúde e da Previdência e Assistência Social, a separação entre os campos de atuação da saúde pública e assistência médica previdenciária. Em que pese esta diferenciação, foi também, segundo as mesmas análises, uma tentativa de introdução de componentes de maior racionalidade em um sistema que, desde a década anterior, favorecia a prestação privada - contratada e financiada pelo Estado a custos crescentes - dos serviços médicos assistenciais, ao mesmo tempo em que deixava à margem do sistema amplos contingentes de trabalhadores não formalmente inscritos no sistema previdenciário (Escorel, 1998: 51-64; Escorel, Nascimento \& Edler, 2005: 64-67).

Medidas racionalizadoras nesta direção tendiam a demandar quadros técnico-científicos nem sempre imediatamente disponíveis nas agências estatais. Esta escassez de competências propiciaria oportunidade de acesso aos postos da burocracia técnica estatal para um contingente de profissionais médicos de posições inovadoras, que vinham gradativamente constituindo um movimento pela reforma do sistema de saúde, como parte do movimento de oposição ao regime (Escorel, 1998: 51-64).

Destas novas posições nas agências estatais, estes membros do nascente movimento sanitário brasileiro - orientados ideologicamente à esquerda e favoráveis à prestação estatal de serviços de saúde - procuraram introduzir mudanças graduais nas bases de organização do sistema de saúde do país. Uma das ações nesse sentido foi a criação do Programa de Interiorização de Ações de Saúde e Saneamento, o Piass (Escorel, 1998: 155-172).

Lançado em agosto de 1976, e formalmente vinculado ao Ministério da Saúde, o Piass teve dois grandes propósitos: aumentar o alcance da cobertura dos serviços médicos, especialmente nas áreas rurais; e viabilizar, com foco nos cuidados primários em saúde, a regionalização da atenção e da assistência médica, de forma descentralizada e hierarquizada. Como um programa estratégico, o Piass refletia uma aproximação da política de saúde brasileira aos princípios defendidos no âmbito da Opas, o que incluía a ênfase no aumento da cobertura dos serviços nas comunidades mais remotas, mediante o uso de pessoal auxiliar, recrutado localmente e capacitado para este fim. Deste modo, como iniciativa estratégica de ampliação da cobertura da atenção médica o Piass requeria necessariamente uma outra, destinada à capacitação de pessoal técnico e auxiliar para a saúde. O Programa de Preparação Estratégica de Pessoal de Saúde, o Ppreps, contemporâneo do Piass, foi uma resposta a esta demanda. 
Ao mesmo tempo em que estas ações eram concebidas e implementadas - e de forma simultânea e articulada -, o movimento da reforma sanitária brasileira avançava em seu processo de organização, alcançando maiores níveis de institucionalidade. Em julho de 1976, um grupo de sanitaristas da Universidade de São Paulo, com o objetivo principal de editar um periódico especializado, instituiu o Centro Brasileiro de Estudos de Saúde (Cebes). Desde então, Saúde em Debate tornar-se-ia um dos principais veículos de difusão do ideário do movimento e o Cebes, uma de suas referências como entidade da sociedade civil (Escorel, 1998: 76).

Entre 1976 e 1978, ampliando o movimento de realização das Semanas de Estudos sobre Saúde Comunitária (Sesacs), os Encontros Científicos dos Estudantes de Medicina transformam-se em reuniões políticas de mobilização dos estudantes de medicina e dos profissionais de saúde. Vários outros exemplos do vigor dos movimentos sociais da saúde no período podem ser indicados: em setembro de 1979, criava-se a Associação Brasileira de Pós-Graduação em Saúde Coletiva (Abrasco) como forma de organização dos programas de pós-graduação no campo da Saúde Pública, da Medicina Social e da Saúde Coletiva. No mês seguinte realizou-se o I Simpósio sobre Política Nacional de Saúde, da Câmara dos Deputados, um evento que reuniu as principais lideranças das várias tendências do movimento ${ }^{20}$.

Em vários destes episódios, em especial nesses dois últimos, a Cooperação Técnica Opas-Brasil desempenharia um importante papel catalisador. Para tanto, se valia da própria flexibilidade proporcionada pela sua natureza algo ambígua - ora movimentando-se como parte da organização interamericana, ora algo como uma paraestrutura do Estado brasileiro. De fato, permeável aos interesses em movimento no contexto local, ao mesmo tempo em que implementava políticas da própria Opas em áreas como da pós-graduação em saúde pública, da reforma da educação médica e na organização de serviços, a Cooperação Técnica era ela mesma uma arena de negociação e um espaço de formulação e coordenação de políticas $^{21}$.

20 Para uma visão abrangente dos primeiros anos do moderno movimento sanitário, ver Escorel (1998) e Paim (1981). Ver também Campos (1995) para o movimento estudantil médico nestes anos. Os anais do seminário encontram-se publicados em Brasil. Câmara dos Deputados, 1980.

21 José Paranaguá de Santana utiliza a expressão "situação anfíbia” para indicar esta relativa imprecisão de vínculos institucionais da Cooperação Técnica. Imprecisão esta em várias ocasiões utilizada pelo próprio Grupo Técnico Central para facilitar negociações com vários parceiros. Ver: Santana, 2005: e.1, f.4. 
A Opas - da mesma forma que agências internacionais privadas como as fundações Rockefeller e Kellogg - já tinha uma tradição de assistência e cooperação técnica no terreno do ensino de medicina e do conjunto das profissões de saúde, tanto na América Latina como no Brasil ${ }^{22}$. Nos anos 1950 e 1960 esta presença se fazia sentir, por exemplo, na introdução do ensino de medicina preventiva e social, da medicina comunitária, assim como no apoio direto à criação, em 1962, da Associação Brasileira de Educação Médica, e da Federação Pan-Americana de Faculdades (Escolas) de Medicina, a Fepafem, que funcionaria inicialmente com sede no Brasil.

A segunda metade da década de 1960 e os primeiros anos 70 foram, por outro lado, na experiência latino-americana, o período de ápice de um ciclo de ampliação quantitativa do ensino médico. Todavia, antes de meados da 1970, já eram explícitas as preocupações quanto à qualidade deste ensino em expansão, tendo sido adotadas medidas mais restritivas à sua ampliação. No Brasil, este aumento seria especialmente concentrado nas escolas isoladas e mantidas pela iniciativa privada. Este incremento quantitativo por certo respondia às demandas crescentes de um mercado público em ampliação e constituía uma resposta às demandas pela formação superior, como modo de ascensão social em sociedades em franco processo de urbanização e complexificação do seu tecido social (Almeida, 2001: 46).

Tratava-se de um ciclo de expansão orientado pela idéia de mercado; concentrado regionalmente no Sudeste como região mais afluente; tendente a promover a especialização precoce e a uma alienação frente aos serviços públicos de saúde. Em resposta a ele, no terreno das doutrinas acerca do ensino médico e das suas relações no plano das práticas de atenção à saúde, verificouse um movimento complexo, portador de ambigüidades e antagonismos, de crítica daquilo que se convencionou chamar modelo flexneriano de ensino médico, a partir dos enunciados da medicina integral, preventiva e comunitária e da radicalização desta crítica, pretendida, por exemplo, pela integração docente-assistencial, com a formulação de enunciados que pretendiam ajustar o ensino médico aos imperativos de uma política de extensão da cobertura dos serviços orientada à atenção primária à saúde ${ }^{23}$.

22 Sobre a história da cooperação técnica entre a Fundação Rockefeller e o Brasil, recomenda-se Castro Santos e Faria (2003) - e Marinho (2001). O papel da Fundação Kellogg constitui ainda importante tema de investigação, dada a escassez de trabalhos historiográficos de maior fôlego. Para um panorama do movimento de integração docente-assistencial no Brasil, que contou com substantivo apoio da Kellogg. Ver Marsiglia (1995). 
Neste contexto, portanto, se tornava cada vez mais presente uma preocupação com as relações estabelecidas entre o chamado sistema formador de médicos e demais profissionais de nível superior em saúde e aquele responsável pela prestação de cuidados. No plano da assistência médica previdenciária, por exemplo, em 1973, já era formalmente explicitadas recomendações no sentido de que os hospitais previdenciários e os postos de saúde sob responsabilidade do então Instituto Nacional de Previdência Social (INPS) fossem colocados à disposição das instituições de ensino. Tal decisão, é preciso dizer, proporcionaria espaços de prática para várias das recém criadas faculdades isoladas que não disponham de hospitais-escola, ao mesmo tempo em que a celebração de convênios entre a Previdência Social e as universidades passavam a prover os recursos financeiros indispensáveis à sobrevivência dos hospitais universitários, às voltas com os custos da especialização e sofisticação tecnológica crescentes (Marsiglia, 1995: 26-27; Sayd, Vieira Junior \& Velandia, 1998: 180).

A V Conferência Nacional de Saúde, de 1975, foi convocada após um longo intervalo de oito anos, na mesma conjuntura temporal em que se realizavam os entendimentos com vistas à celebração de um acordo de cooperação em recursos humanos entre o governo brasileiro e Opas. Seus temas e debates reafirmavam aquelas preocupações. Identificava-se um desajuste entre uma oferta de cursos de formação profissional em expansão e as necessidades das populações, ao mesmo tempo em que se criticava o excessivo foco nos aspectos curativos e especializados tanto nos processo de formação profissional, quanto na prestação de serviços médicos, em detrimento da dimensão preventiva. Reiterava-se a necessidade de uma maior articulação das ações institucionais no âmbito da saúde, da educação e da previdência e assistencial social, como pré-condição para uma maior racionalidade e eficiência do sistema global. Com o mesmo objetivo racionalizador, foi conferida atenção crescente à formação de pessoal não médico, inclusive nos níveis médio e elementar ${ }^{24}$.

23 O uso desta classificação se fundamenta na sua descrição presente em Lampert (2002: 31-52); Schraiber (1989: 104-127); Veras, (1981: 86-92); Rodriguez Neto, 1979 e Feuerwerker (1998: 51-56), que comportam variações entre si. Para uma crítica no uso deste tipo de categorização a partir de modelos, em particular ao chamado modelo flexneriano, ver Kemp \& Edler, 2004: 570-574. De qualquer modo, é importante salientar que estas percepções modelares são elas mesmas construídas no calor da hora da revisão crítica, operada pelos intelectuais e profissionais da saúde ao longo dos anos 60 e início dos 70.

24 Para um panorama da presença do tema do ensino médico e dos recursos humanos nas conferências nacionais de saúde entre 1941 e 1992, ver Sayd, Vieira Junior \& Velandia, 1998. Os anais da V Conferência Nacional de Saúde estão em Brasil. MS, 1976. 
Em meados dos anos 1970, a celebração do Acordo Geral para o Desenvolvimento de Recursos Humanos para a Saúde entre a Opas e o governo brasileiro e a implementação do Ppreps seriam certamente informadas por este debate, inclusive estendendo-o em uma escala até então jamais pretendida e que, àquela altura, era compatível com as expectativas acerca de uma acelerada expansão da cobertura dos serviços de saúde. Ao fazê-lo, a Cooperação Técnica Opas-Brasil contribuiria, também decisivamente, tanto para a conformação em âmbito nacional de redes sociais e de aparatos públicos especialmente voltados para o desenvolvimento de recursos humanos, como para o estabelecimento de um domínio cognitivo. $\mathrm{O}$ seu percurso histórico nos primeiros anos é o objeto dos próximos capítulos. 


\section{Primeiros Movimentos: a gênese da COOPERAÇÃO TÉCNICA (1973-1976)}

Do ponto de vista estritamente econômico, como já indicado, na primeira metade dos anos 1970 ocorreu o epicentro do chamado milagre econômico brasileiro, marcado por taxas altas de crescimento econômico, uma tendência à expansão que se manteve ao longo da década, mesmo sob o impacto da primeira crise do petróleo. Em meados da década teve início a crise do modelo de desenvolvimento adotado pelo regime autoritário e da sua própria sustentação política. O cenário macroeconômico, com disponibilidade relativa de recursos orçamentários, permitia ao Estado autoritário expandir suas estruturas e âmbitos de ação. Já a necessidade de recuperação de seus níveis de legitimidade social induziu a implementação de políticas públicas consideradas em certo sentido inovadoras. Neste movimento, as estruturas deste mesmo Estado se mostravam permeáveis à constituição de grupos especializados, mais ou menos autônomos, que facilitariam, em tese, a formulação e gestão de políticas públicas.

Sobre esta base econômica e neste contexto político e institucional, autoridades governamentais e médicas renovaram o debate acerca da ampliação da cobertura dos serviços públicos de saúde, afirmando a sua centralidade estratégica como tema do planejamento. Em torno desta pauta se congregariam, além de agências nacionais, organizações internacionais como a Organização Pan-Americana da Saúde (Opas/OMS).

Como tópicos desta agenda, incluíam-se o diagnóstico e a implementação de iniciativas voltadas para a formação e treinamento do pessoal de saúde, 
tendo em vista enfrentar a concentração de profissionais nos grandes centros urbanos e a necessidade de mudança de um padrão de formação dos recursos humanos considerado desconectado das necessidades de saúde da população do país.

Neste capítulo narra-se o processo de gênese e instituição, em 1976 e, portanto, neste contexto, do Programa de Preparação Estratégica de Pessoal de Saúde, (Ppreps) no âmbito de um acordo de cooperação técnica estabelecido três anos antes entre a Opas e o governo brasileiro, representado pelo Ministério da Saúde (MS) e pelo Ministério da Educação e Cultura (MEC). Apresentam-se os objetivos e as estratégias inicialmente formuladas para o desenvolvimento do programa, assim como o arranjo institucional adotado para a sua gestão e os mecanismos e recursos mobilizados no seu financiamento. Em seguida, à luz dos aspectos contextuais apresentados no capítulo anterior, discute-se o que seria o sentido estratégico da proposição do programa.

\section{A Criação do Ppreps: antecedentes imediatos}

Quando o mexicano Héctor Acuña, diretor da Organização Pan-Americana da Saúde, desembarcou em Brasília no início de agosto de 1975, tinha pelo menos dois compromissos relevantes. O primeiro deles foi participar da V Conferência Nacional de Saúde, realizada nos salões do Palácio Itamaraty. O segundo foi participar, na companhia de Paulo de Almeida Machado e de Jarbas Passarinho, os ministros brasileiros das pastas da Saúde e da Educação e Cultura, da cerimônia de assinatura do instrumento formal que estabeleceria as bases para que, meses depois, entrasse em operação o Programa de Preparação Estratégica de Pessoal de Saúde, o Ppreps.

Em seus discursos na sessão de encerramento da Conferência, Acuña e Almeida Machado reafirmavam a relevância das políticas sociais como componente do desenvolvimento, tal como pretendido pelo então recém-lançado II Plano Nacional de Desenvolvimento (V CNS, 1975: 315-326).

Ambos foram também explícitos ao conferir centralidade aos temas dos recursos humanos na conformação do Sistema Nacional de Saúde, instituído em julho do mesmo ano. A este respeito, Almeida Machado reiterava um diagnóstico já conhecido: a má distribuição da força de trabalho em saúde ao longo do território e uma excessiva concentração na formação de profissionais de nível superior, em especial de médicos, em detrimento do contingen- 
te de trabalhadores de nível técnico, auxiliar e mesmo elementar. As estratégias para a abordagem destes temas deveriam incluir, no entender de Acuña: a utilização de elementos da comunidade local, das suas lideranças, uma vez participando de processos de capacitação.

Ao firmarem um acordo de cooperação explicitamente orientado ao desenvolvimento de recursos humanos em saúde, Acuña e os ministros brasileiros estavam renovando esforços iniciados três anos antes, em 1973. Em novembro daquele ano, o então diretor da Opas, Abraham Horwitz, o Ministro da Saúde, Mario Machado de Lemos, e o Ministro da Educação e Cultura, Jarbas Passarinho, haviam firmado um Acordo para um Programa Geral de Desenvolvimento de Recursos Humanos para a Saúde no Brasil ${ }^{25}$. Neste instrumento, tendo por orientação as recomendações presentes no II Plano Decenal de Saúde para as Américas, de outubro de 1972, o governo brasileiro e a organização internacional regional estabeleceram três objetivos centrais para uma cooperação técnica. No primeiro, pretendia-se promover as ações de planejamento e desenvolvimento dos recursos humanos no âmbito do setor, o que incluía a elaboração de um plano de recursos humanos em saúde.

O segundo objetivo era aumentar a integração entre o sistema formador e a realidade da rede assistencial. Para tanto, pretendia-se propiciar maiores oportunidades para a utilização de todos os recursos do setor saúde como parte do processo de ensino-apredizagem; estimular a integração multiprofissional como necessária ao adequado funcionamento das equipes de saúde; rever os modos de organização de instituições docentes e prestadoras de serviços, assim como promover o desenvolvimento curricular e técnico-pedagógico, sempre orientado a uma maior integração entre a docência e serviço.

O terceiro objetivo, por fim, voltava-se para o fortalecimento da formação de pessoal docente e de pesquisa, mediante a concessão de bolsas de estudo e o apoio financeiro e técnico científico às instituições de pós-graduação. Dentre os temas de investigação a serem considerados, incluía-se o desenvolvimento de metodologias de educação continuada.

Em junho de 1974, o Ministro da Saúde instituiu uma comissão com o objetivo de avaliar as disponibilidades e necessidades do setor no que concerne aos recursos humanos. Compunham a comissão Ernani Braga, da Universidade Federal do Rio de Janeiro (UFRJ), Oswaldo Lopes da Costa, diretor da

25 A rigor, enquanto o Ministro da Saúde e o Diretor da Opas assinaram o compromisso em 14 de novembro de 1973, o Ministro da Educação e Cultura apenas o faria em 10 de março do ano seguinte. 
Escola Nacional de Saúde Pública (Ensp), Aldo Villas Boas, presidente da Fundação Serviço Especial de Saúde Pública (FSESP), João Yunes, chefe do Gabinete do Ministro da Saúde, José Campos Sampaio, delegado do MS em São Paulo e Mário Sayeg, do Departamento de Administração e Planejamento da Escola Nacional de Saúde Pública ${ }^{26}$. Ao final dos trabalhos, em novembro de 1974, foi apresentado um relatório final contendo a proposta de um Plano de Recursos Humanos para a Saúde (Ppreps, 1976: 3; Brasil. Ministério da Saúde, 1974: 9).

Esse documento previu o desenvolvimento de projetos destinados ao atendimento de três grandes áreas de ação: de planejamento de recursos humanos; de preparação direta de recursos humanos para a saúde; e de apoio ao que seria "o desenvolvimento de um programa nacional de preparação e distribuição estratégica de pessoal de saúde” (Brasil. Ppreps, 1976: 3).

Foi em torno desta terceira e última área que, na altura do primeiro semestre de 1975, José Roberto Ferreira, pela Oficina da Opas em Washington, o peruano Carlos Vidal, como consultor da Organização no país, e Ernani Braga começaram a se movimentar no sentido de produzir uma proposta concreta. Aproveitavam-se, então, de uma conjuntura favorável no âmbito da administração federal brasileira para iniciativas em torno da temática dos recursos humanos, caracterizada, entre outras ações, pela criação e funcionamento do Centro Nacional de Recursos Humanos, no Instituto de Pesquisa Econômica Aplicada (Ipea), e de uma subsecretaria de recursos humanos, no próprio Ministério da Saúde (Ferreira, 2005: e.1,f.1; Santana, 2005: e.1,f.1)27.

A ousadia de Carlos Vidal resultou na elaboração de uma proposição cujos componentes orçamentários eram considerados pelo próprio trio de autores como algo dificilmente aceitável pelos ministérios. Na verdade, na metade da década de 1970 registrava-se uma importante disponibilidade de recursos mais ou menos vultosos para o desenvolvimento de novos programas e projetos, em vasta medida decorrência da política governamental de manter a capacidade para investimentos por meio do endividamento externo. $\mathrm{Na}$ saúde esta facilidade proporcionou o lançamento de programas como o Programa de Interiorização das Ações de Saúde e Saneamento (Piass), o Programa de Estudos Socioeconômicos em Saúde (Peses), o Programa de Estu-

\footnotetext{
${ }_{26}$ À época, a Ensp denominava-se Instituto Presidente Castelo Branco, IPCB.

${ }^{27}$ Adotamos a seguinte regra para a referência das entrevistas de história oral: nome do depoente, seguido do ano da realização da entrevista, número da sessão ou entrevista, e, por fim, número da unidade de fita magnética de gravação.
} 
dos Populacionais e de Pesquisas Epidemiológicas (Peppe), de consolidação da Biblioteca Regional de Medicina - Bireme, entre outras iniciativas impor$\operatorname{tantes}^{28}$. Deste modo, enviada a Brasília, a proposta do Ppreps terminou por ser, meses depois, aprovada integralmente.

Imaginou-se, a princípio, que a Ensp deveria sediar o programa. Seu diretor à época, Oswaldo Lopes da Costa, todavia, manifestou-se de modo terminantemente contrário à iniciativa, acreditando que as implicações administrativas de tal empreitada estavam além da capacidade gerencial da Escola. A alternativa foi considerar a possibilidade de sediar as atividades na própria Opas, uma decisão apoiada por José Carlos Seixas, Secretario Executivo do MS e, João Yunes, Chefe de Gabinete (Ferreira, 2005:e.1; f.1).

Em agosto de 1975, em plena V Conferência Nacional de Saúde, o Acordo Complementar ao acordo de 1973 seria assinado pelas partes, formalizado o compromisso de levar adiante o empreendimento ${ }^{29}$. Nos meses seguintes, porém, Vinicius da Fonseca, recém-empossado como presidente da Fundação Oswaldo Cruz (Fiocruz), alterou a posição da Fundação diante da iniciativa. Fonseca tinha como missão reestruturar a Fiocruz, tanto do ponto de vista da sua identidade institucional, da organização de sua estrutura político-administrativa, como dos seus recursos humanos e financeiros. Nesse ponto, a possibilidade de atuar como instituição gestora do Acordo contribuiria, nas suas próprias palavras, para "legitimar Manguinhos internacionalmente" (Hamilton \& Azevedo, 2001: 256). Assim, em dezembro de 1975, um Termo Aditivo ao Acordo Complementar definiu a Fiocruz como instituição responsável pela gestão administrativa dos recursos transferidos pelo Ministério da Saúde (Opas. Brasil, 1975b).

Firmado o compromisso, o passo seguinte foi estabelecer as diretrizes gerais de orientação e instituir um grupo de trabalho que seria responsável pela elaboração de um programa de ação. Para tanto foi realizado um seminário em Brasília, sob os auspícios da Opas e do Ministério da Saúde, na sede do Instituto Nacional de Nutrição (Inan), à época dirigido pelo pernambucano Bertoldo Kruse (Ferreira, 2005). O grupo para a condução do programa foi composto tendo como indicações do Ministério da Saúde o médico Cesar

28 Para estes programas e o seu contexto de criação ver Nunes (1998) e Pires-Alves (2005). Para um panorama da economia brasileira no período ver, por exemplo, Gremaud et al. (2002).

29 Foram signatários do acordo Héctor Acuña, pela Opas; Paulo de Almeida Machado, pela pasta da Saúde; e Ney Braga, como ministro da Educação e Cultura. 
Vieira, da Secretaria de Saúde de Minas Gerais, a enfermeira Izabel dos Santos, da Universidade Federal de Pernambuco, Danilo Prado Garcia, cirurgião em São Paulo. Da parte da Opas, atuaram como consultores o chileno Francisco Salazar e o argentino Garcia Scarpone. O sanitarista Sergio Arouca chegou a tomar parte das primeiras reuniões ${ }^{30}$. Sua efetiva participação, porém, não se concretizou (Macedo, 2005). Dalton Mário Hamilton, argentino, então consultor da Opas, e Eugênio Vilaça Mendes, à época na Secretaria de Saúde de Minas Gerais, também foram nesta primeira hora sondados para participar da equipe do Ppreps. Ao contrário de Arouca e Hamilton, porém, Vilaça Mendes terminaria por se incorporar à equipe nove anos depois, em 1984, como coordenador da Cooperação Técnica, em substituição a Roberto Nogueira (Santana, 2006). Àquela altura, todavia, o escopo, a estruturação e a forma de operação da cooperação técnica seriam substantivamente diferentes ${ }^{31}$.

Nos primeiros momentos da Cooperação Técnica Opas-Brasil em Recursos Humanos, o médico piauiense Carlyle Guerra de Macedo foi designado para exercer o papel de coordenador do grupo de trabalho. Carlyle, exsecretário de Saúde do Piauí, com passagem pela Superintendência de Desenvolvimento do Nordeste (Sudene), havia encerrado uma temporada como professor do Instituto Latino-Americano de Planejamento Econômico e Social (Ilpes) em Santiago do Chile, país que recém ingressara nos dramáticos anos da ditadura Pinochet. Sua indicação contou com o patrocínio do então Ministro da Justiça, Petrônio Portela, e foi capaz de vencer resistências nos meios mais conservadores do regime militar, receosos das suas antigas ligações com Celso Furtado e a Sudene ${ }^{32}$.

Paralelamente, os Ministérios da Educação e Cultura, da Saúde e da Previdência e Assistência Social instituíram um grupo de trabalho com o propósito de formular uma política conjunta ${ }^{33}$. Este grupo de trabalho elaborou

30 Em seus depoimentos, Carlyle Guerra de Macedo e César Vieira registram que Sergio Arouca teria sido sondado para assumir a coordenação do programa (Macedo, 2005: e.1,f.1; Vieira, 2006: e.1, f.1). Esta versão, todavia, não é confirmada por José Roberto Ferreira. Este indica que Arouca foi cogitado apenas para integrar a equipe técnica (Ferreira, 2005: e.1, f.1).

31 Informações sobre a Cooperação Técnica em RH em meados da década de 1980 estão nos capítulos 4 e 5 .

32 Carlyle permaneceu como coordenador desse grupo de trabalho, depois Grupo Técnico Central (GTC) do Ppreps até 1983, sempre na condição de funcionário nacional da Opas no país, uma situação funcional atípica. Neste ano foi eleito Diretor da Opas.

33 Este grupo de trabalho foi composto por Célio da Cunha, pelo MEC; Maria Stella Winge, pelo MS; e Nildo Aguiar e Antonio Vespasiano Ramos, pelo MPAS. Foram entrevistados vários especialistas e dirigentes das três áreas. Entre eles incluíam-se: João Yunes, José Carlos Seixas, Nilo Chave, Sólon Viana e Carlyle Guerra de Macedo (BRASIL. MEC, 1976) 
um extenso e completo programa de ação, dando conta de aspectos relativos às profissões de nível superior; ao ensino de pós-graduação; ao ensino técnico e auxiliar de nível médio, assim como sobre a extensão universitária - as então chamadas carreiras de curta duração. Suas conclusões apontavam para a necessidade: de uma maior articulação entre várias áreas de atuação ministerial; da celebração de convênios de cooperação mútua; de um aumento do número e na qualidade da formação de pessoal de nível intermediário; de adequação dos currículos, frente aos problemas de saúde mais freqüentes; de ênfase na formação de caráter generalista; de incremento das experiências de extensão universitária, entre outros (Brasil. MEC, 1976). Como veremos mais adiante, vários destes tópicos serão enfrentados pela Cooperação Técnica OpasBrasil em recursos humanos. Todavia, a tão desejada articulação entre as pastas ministeriais dependeria, ainda, de um longo processo de maturação.

Em junho de 1976, o grupo da Cooperação Opas-Brasil levou à consideração do Ministro da Saúde um documento de referência para a criação daquele que seria o Programa de Preparação Estratégica de Pessoal de Saúde, o Ppreps.

O propósito do programa era adequar a formação de recursos humanos para a saúde no país àqueles que seriam os requerimentos do novo Sistema Nacional de Saúde (SNS), de modo a atingir-se a maior cobertura possível, de maneira integral e regionalizada, segundo os diferentes níveis de complexidade e ajustado à realidade socioeconômica das várias regiões brasileiras. Dado este propósito comum, de caráter geral, foram definidos três objetivos.

O primeiro deles envolvia a preparação massiva de pessoal de saúde de nível médio, de tipo técnico e auxiliar, e elementar. As metas inicialmente previstas eram ambiciosas e correspondiam àquelas estimadas pelo grupo interministerial de 1974: entre 160 mil e 180 mil pessoas capacitadas durante o período de 1976-1979, cobrindo as mais diversas categorias profissionais, com ênfase naquelas vinculadas diretamente à prestação de serviços médicos e de características polivalentes, sem descuidar dos serviços intermediários e de apoio técnico e administrativo (Ppreps, 1976:5-6). Entre as categorias previstas, incluíam-se principalmente técnico de enfermagem, auxiliar de enfermagem, atendentes e agentes comunitários. As ações a serem implementadas especificamente pelo programa diziam respeito ao desenvolvimento da capacidade docente, no que concerne às instalações e aos instrutores, às tecnologias instrucionais, bem como à supervisão e à comunicação, visando uma educação continuada. Entre as parcerias imaginadas para o desenvolvimento deste 
último aspecto figuravam a Escola de Saúde de Minas Gerais, para a formação de pessoal de nível elementar, e o Centro Latino-Americano de Tecnologia Educacional (Clates-Nutes), na Universidade Federal do Rio de Janeiro (UFRJ), para a formação pessoal de nível técnico nas áreas de enfermagem, laboratório e administração (Ppreps, 1976: 12-16, 35).

O segundo objetivo do Programa consistiu no apoio à constituição de dez regiões docente-assistenciais de saúde, de maneira a atingir-se uma cobertura final de 15 a 20 milhões de pessoas em todo o país. Esta integração deveria se efetivar em todos os níveis da formação de recursos humanos para a saúde e em todos os âmbitos de assistência do sistema de serviços. Deveria permitir a experimentação de modelos, métodos e procedimentos, em apoio ao processo de regionalização dos serviços, a partir de uma articulação técnica e administrativa entre as várias instituições do setor e entre estas e as instituições formadoras, em especial com a universidade (Ppreps, 1976: 7). Esse objetivo, diretamente associado às metas de aumento da cobertura e de regionalização dos serviços de saúde, deveria contribuir para a definição de um novo rumo na formação de pessoal de saúde, mais integrado às necessidades e às prioridades dos próprios serviços médicos, um requisito fundamental para o desenvolvimento do desenvolvimento do Sistema Nacional de Saúde (SNS).

De acordo com texto do Ppreps, entretanto, caberia estritamente ao programa "a formulação e operação dos mecanismos de articulação e/ou integração entre sistemas formador e utilizador para uma melhor adequação da formação às necessidades reais de recursos humanos para a saúde" (Ppreps, 1976: 8; Macedo, Santos \& Vieira, 1980: 65).

Com esta frente de atuação, o Ppreps alinhava-se a um movimento de alcance continental, apoiado pela Fundação Kellogg, que pretendia uma reorganização do ensino de medicina, com um fortalecimento dos componentes de interação entre ensino e serviço, com ênfase na cooperação interdepartamental e multiprofissional (Chaves, 1994: 6).

No Brasil, por exemplo, a Kellogg apoiaria a realização de uma reunião para discussão de iniciativas IDA no âmbito de programas de saúde maternoinfantil e de um Encontro de Integração Docente-Assistencial do Estado de São Paulo, em parceria com a Secretaria Estadual de Saúde, ao mesmo tempo em que proporcionava suporte financeiro e técnico a várias iniciativas. A IDA compunha também as orientações adotadas no âmbito do Ministério da Educação e Cultura na condução do ensino superior médico (Marsiglia, 1995: Sesu-MEC: 1981a). Portanto, o desenvolvimento de projetos IDA não era 
àquela altura um domínio exclusivo ou tampouco uma preocupação solitária Opas e da Cooperação Técnica.

Um terceiro e último objetivo do Ppreps foi apoiar o estabelecimento de sistemas de desenvolvimento de recursos humanos para a saúde em cada estado federativo, de forma integrada aos sistemas de planejamento setorial regional. Essa meta, complementar às demais, na prática significou também uma estratégia de apoio ao desenvolvimento das secretarias de saúde estaduais, já que o Programa se propunha a atuar operacionalmente de forma descentralizada. Além disso, permitiria o desenvolvimento de recursos humanos como atividade permanente e em sintonia com as necessidades dos serviços locais de saúde (Ppreps, 1976: 9; Macedo, Santos \& Vieira, 1980: 66).

Dados esses objetivos, definiu-se uma estratégia geral que explicitava a necessidade a articulação e a cooperação entre diversos órgãos e setores participantes do programa, desde instituições integrantes do Sistema Nacional de Saúde até órgãos do planejamento global e do desenvolvimento. O programa não pretendia criar novos estruturas organizacionais, mas a articulação daqueles já existentes - quando isolados - a um sistema de formação-serviço em âmbito tanto regional quanto nacional.

Assim, pretendia-se acionar os diversos níveis da administração federal e estadual, o que incluía, no âmbito do MEC, os departamentos de Assuntos Universitários, de Educação Média e Ensino Supletivo, assim como o Movimento Brasileiro de Alfabetização, o Mobral. Entre outras áreas do executivo federal: o Ministério da Previdência e Assistência Social, recém-criado; o Ministério do Trabalho; o Ministério do Interior; a Secretaria de Planejamento da Presidência da República (Seplan), e as áreas especializadas das superintendências regionais de desenvolvimento, entre as quais a Sudene. No âmbito estadual, as secretarias estaduais de saúde foram pensadas estrategicamente tendo em vista a pretendida descentralização das atividades do programa.

Estratégias específicas e planos de ação foram desenhados para cada um dos objetivos. Para a formação em massa de pessoal, referente ao primeiro objetivo, as principais orientações incluíram: apoiar as secretarias estaduais de saúde como órgãos centrais para a implementação de projetos de treinamento para o sistema de saúde do estado; o aproveitamento das modalidades de ensino supletivo e profissionalizante existentes de modo a alcançar uma habilitação formal; a criação de cursos, especialmente para o nível auxiliar, nas unidades de saúde que apresentassem condições técnicas consideradas adequadas; a ênfase na capacitação integrada ao serviço e de 
caráter polivalente; o desenvolvimento de modelos instrucionais adequados à capacitação em massa, a custos compatíveis e aplicáveis ás diversas situações que o país apresentava.

O Programa aconselhava, também, um esquema de prioridades orientado aos subsistemas do MS e das secretarias estaduais e, secundariamente, à rede do Ministério da Previdência e Assistência Social ao subsetor privado (Ppreps, 1976: 12-160). Seriam realizados projetos de treinamento de pessoal de saúde em 16 estados da federação e estabeleceu-se que, a médio prazo, as atividades de capacitação massiva em nível elementar e médio deveriam ser integradas às regiões docente-assistenciais formuladas para o segundo objetivo geral do programa ${ }^{34}$ (Macedo, Santos \& Vieira, 1980: 64-65).

O segundo objetivo, referido à criação das regiões docente-assistenciais, requeria o desenvolvimento prévio de análises sociopolíticas e administrativas, de modo a identificar o que seriam as variáveis essenciais das diferentes realidades institucionais regionais. Pretendia-se que as atividades englobassem a promoção de uma reorganização dos serviços de atenção em cada região, a formulação de programas docentes específicos e o estabelecimento de mecanismos integradores entre os sistemas de saúde de formação. As estratégias quanto a este tópico incluíram, ainda, assegurar a inclusão dos setores de saúde e educação nos planos e programas de desenvolvimento em âmbito regional e estadual e adotar a flexibilidade necessária para, aproveitando as iniciativas em andamento ou em processo de gênese, desenvolver experiências de várias amplitudes (Macedo, Santos \& Vieira, 1980: 65).

Assim, admitia-se a definição de dois tipos de região docente-assistencial. O primeiro deles, a integral, seriam aquelas dotadas de serviços completos, do nível mais simples ao mais complexo, atingindo uma população da ordem de um a 2,5 milhões de habitantes. A princípio, foram pré-selecionados para a implantação das regiões docente-assistenciais os estados do Piauí e da Paraíba (Ppreps, 1976: 16-19 e 35).

O segundo tipo, parcial, se destinaria às áreas de dimensões menores, permitindo o apoio às iniciativas de integração docente-assistencial já em andamento. Dentre as iniciativas pré-selecionadas se incluíam aquelas em realização em Vitória de Santo-Antão (PE), Londrina (PR) e na região de Montes

\footnotetext{
34 Os estados onde seriam desenvolvidos os projetos eram: Pará, todos os da região Nordeste, além de Minas Gerais, Rio Grande do Sul, Goiás, Santa Catarina, Espírito Santo, e Mato Grosso (Ppreps, 1976: 34-35).
} 
Claros, norte do estado de Minas Gerais ${ }^{35}$ (Ppreps, 1976: 35). Uma outra preocupação era possibilitar a formação de pessoal de direção, gerência e docência para os serviços de saúde.

O terceiro e último objetivo, considerado de natureza complementar aos precedentes, em larga medida seguia a mesma orientação estratégica destes. Adicionalmente, pretendia-se uma articulação aos demais projetos de desenvolvimento de recursos humanos em andamento na esfera federal, em especial no âmbito da Assessoria de Recursos Humanos do Ministério da Saúde, à época chefiada por Stella Winge e parte integrante da secretaria geral do ministério. (Nogueira, 2005: e. 1, f. 1).

Em sua dimensão operacional, o Programa estabeleceu como responsabilidades específicas: promover a participação das várias instituições integrantes do sistema, estimulando que cada uma delas assumisse a realização das atividades executivas diretas; realizar a coordenação das várias instituições participantes e proporcionar suporte técnico e financeiro às instituições executoras, além de outras atividades correlatas. Sua função, portanto, consistia no desempenho de atividades de organização, programação, apoio e acompanhamento das ações, cuja dimensão executiva ficaria a cargo das instâncias e áreas organizacionais dos executivos federal e, principalmente, estadual.

Foram definidas, como instâncias de organização central do Programa, a Comissão de Coordenação (CC) e o Grupo Técnico Central (GTC). Prevista originalmente no texto do Acordo de 1973 e presidida pelo Secretario Geral do Ministério da Saúde, a CC tinha como responsabilidade a orientação dos trabalhos do GTC, aprovar programas, projetos e convênios, assim como exercer o papel de instância de acompanhamento e avaliação do programa. Com um regime de funcionamento que previa a realização de reuniões mensais, tinham acento no CC os representantes do Ministério da Educação e Cultura, do Ministério da Saúde, da Fiocruz e da Opas ${ }^{36}$. O coordenador do GTC atuaria como secretario das seções, sem usufruir, no entanto, de direito de voto.

O Grupo Técnico Central (GTC), instituído efetivamente em março de 1976, era o núcleo técnico e gerencial do Programa, principalmente em relação à mobilização e à articulação de fato dos vários atores institucionais. Suas

\footnotetext{
35 Previa-se o estabelecimento de outras três regiões docente-assistenciais nos estados de São Paulo, Pará e Rio de Janeiro ou Espírito Santo (Ppreps, 1976: 35).

${ }^{36}$ Ver especialmente o Anexo 1, de Ppreps (1975:55).
} 
atribuições incluíam, ainda, a realização de ações de orientação conceitual e de elaboração de modelos metodológicos; a identificação de fontes de financiamento e a captação de recursos adicionais; a contratação de serviços de assessoria complementares; além das responsabilidades de informação e de documentação do Programa.

Administrativamente, o GTC ficava diretamente subordinado à Opas. Tal vinculação, todavia, não implicava uma subordinação político-técnica à Organização. Ao contrário: o documento de referencia do Ppreps foi explícito em indicar que ao GTC cabia "a responsabilidade de promover a implementação de um programa inteiramente nacional e sua subordinação política, técnica e funcional [era] às autoridades nacionais através da CC" (Ppreps, 1976: 26).

Como já assinalado anteriormente, à Fiocruz caberiam as atividades de gestão dos recursos financeiros, o que incluía o repasse à Opas dos recursos para a remuneração do GTC. Desta forma - vale a pena assinalar - os membros do GTC contratados pela Opas, embora funcionários nacionais, recebiam a remuneração baseada em seus valores em dólar. Anos mais tarde, em 1983, este tipo de regime de contratação teria de ser revisto, tendo em vista as restrições na disponibilidade de moeda conversível que a crise da dívida externa imporia às contas nacionais do conjunto de países da região, o que não deixou de produzir algum desgaste político e mesmo pessoal no interior da equipe.

Basicamente o programa funcionaria mobilizando e apoiando atores institucionais, que elaborariam os projetos a serem avaliados em primeira instância ao GTC, encaminhados para análise e pronunciamento do CC e que, posteriormente, seriam objeto de um convênio para a formalização da cooperação.

Os recursos necessários ao desenvolvimento do Programa seriam provenientes principalmente de repasses do Ministério da Saúde. Nenhum recurso financeiro foi explicitamente considerado como de responsabilidade do Ministério da Educação e Cultura, além de uma imprecisa possibilidade junto a eventuais "programas e atividades especiais". Previa-se que recursos adicionais poderiam ser obtidos junto às agencias de financiamento como a Finep, órgãos de desenvolvimento regional, entres os quais a Sudene, fundos especiais como o Fundo de Apoio ao Desenvolvimento Social (FAS), além de contribuições em caráter extraordinário do Instituto Nacional de Previdência Social (INPS) e do Fundo de Assistência ao Trabalhador Rural (Funrural). 
A constituição desta espécie de trust fund entre a Opas e o governo brasileiro pretendia repetir o tipo de arranjo institucional e de mecanismos de repasse e gestão de recursos já adotados alguns anos antes pela organização intergovernamental e o governo do México na ampliação da rede de estabelecimentos de ensino de medicina veterinária naquele país (Ferreira, 2005: e.1, f.1).

Segundo o texto do Acordo, assinado em agosto de 1975, o Ministério da Saúde transferiria, no exercício de 1975, a quantia de 15 milhões de cruzeiros $(\mathrm{R} \$ 17.250 .000,00)$ para a Fundação Oswaldo Cruz (Fiocruz), sendo $\mathrm{Cr} \$ 13.689 .000,00(\mathrm{R} \$ 15.750 .000,00)$ relativos às obrigações estabelecidas pelos convênios celebrados pela Fiocruz e Cr\$1.311.000,00 ( $\mathrm{R} \$ 1.508 .000,00)$ para a Opas, decorrente dos encargos com o Grupo Técnico ${ }^{37}$. Além disso, o Ministério se comprometia a transferir nos exercícios subseqüentes os recursos estabelecidos expressamente em seus orçamentos anuais.

A Opas, por sua vez, se comprometia a dispor seus consultores residentes nas zonas de atuação da organização. A seleção dos profissionais que comporiam o Grupo Técnico seria realizada em comum acordo entre a Organização e a Fiocruz, cabendo a última palavra aos ministérios. Tal como na versão de 1973, o texto do Acordo Complementar de 1975 definiu a sua vigência até 31 de dezembro de 1978, com possibilidade prorrogação e modificação, o que de fato ocorreu no final desse período.

\section{O ENQUADRAMENTO ESTRATÉGICO}

O período entre novembro de 1973 e agosto de 1975 assinala a gestação de uma nova agenda para a formação de recursos humanos para a saúde no Brasil. O Acordo de 1973 tratava, essencialmente, da promoção da adequação do sistema de formação de recursos humanos brasileiro à realidade da rede assistencial, com atenção para a formação de pessoal de nível elementar, técnico e superior, o que se coadunava também à necessidade de elaboração de uma agenda de recursos humanos em saúde para o Brasil. A partir dessa base, constituiu-se, em 1974, um grupo técnico voltado para a produção de um diagnóstico sobre a realidade dos recursos humanos em saúde do país e propor uma pauta de objetivos e estratégias. Em apenas um ano, as questões

37 A conversão para valores em reais, em setembro de 2006, é obtida mediante a aplicação do Índice Geral de Preços - Disponibilidade Interna (IGP-DI) da Fundação Getúlio Vargas. Conversão automática disponível em: http://www.fee.tche.br/sitefee/pt/content/servicos/ pg_atualizacao_valores.php. Acessada em 20.09.2006. 
apontadas pelo relatório produzido por esse grupo se desdobraram na assinatura de um acordo complementar, assinado em novembro de 1975.

Sob o signo da expansão da cobertura dos serviços de saúde, sobretudo para o meio rural, este movimento correspondia a um processo de renovação da agenda estratégica em recursos humanos na saúde. Se nos anos 60 a ênfase recaiu na necessidade de aumentar o número de profissionais de nível superior disponíveis, sobretudo médicos, a década seguinte se orientaria para a necessidade da capacitação de um novo e expressivo contingente de trabalhadores de nível elementar e médio. Ao mesmo tempo, assinalava o imperativo de uma integração entre os processos de formação e de trabalho, entre a docência e os serviços de atenção à saúde, tanto para a capacitação destes novos trabalhadores, quanto para a formação de médicos, enfermeiros e odontólogos.

Este movimento, no plano interamericano, em particular na Opas, assinalava uma crescente afirmação dos recursos humanos como tema estratégico em saúde. Era, também, expressão da necessidade de modelos inovadores na implementação de iniciativas de cooperação técnica que, superando a assistência técnica, marcada pela idéia de subordinação e dependência, propiciassem uma melhor mobilização e a reprodução ampliada das competências nacionais.

Entretanto, ainda que o acordo de cooperação técnica de 1973 que lançou as bases do Programa de Preparação Estratégica de Pessoal de Saúde, o Ppreps, legitimasse e fosse ao mesmo tempo legitimado por movimentos em escala internacional, tal como expressos, por exemplo, na Carta de Punta del Este (1961) e, principalmente, no II Plano Decenal de Saúde (1973), ele representou e articulou vários atores institucionais nacionais em favor de uma agenda eminentemente atrelada às discussões e necessidades do país. Neste sentido, ele deve ser observado, no âmbito interno, como intimamente associado à formulação e implementação do Sistema Nacional de Saúde e do Programa de Interiorização das Ações de Saúde e Saneamento (Piass).

Como indício desta articulação estratégica, pode-se mencionar que ambos programas, em seu primeiro momento, conferiam centralidade às ações desenvolvidas nas regiões Norte e Nordeste do país, as regiões consideradas as mais carentes no que concerne aos recursos humanos e à infra-estrutura em saúde. De outro, vale mencionar que, desde a primeira hora, o Ppreps assumiu uma perspectiva descentralizadora, tanto ao se propor a promover o fortale- 
cimento de competências locais para o desenvolvimento de recursos humanos em saúde, quanto ao afirmar seu compromisso com a constituição de sistemas de atenção integral, hierarquizada e regionalizada.

No plano interno, o Ppreps significou a implementação de um modelo de resposta relativamente planificado para as demandas nacionais, constituindo-se em um arranjo institucional e programático que procurava alinhar-se aos objetivos do II Plano Nacional de Desenvolvimento (1975). Foi parte das preocupações do regime militar em introduzir - ainda que de forma restrita e autocrática - uma pauta social na agenda do desenvolvimento, como forma de renovar as condições de reprodução deste mesmo regime.

Nas circunstâncias daqueles que foram os últimos anos de expansão dos gastos públicos, às vésperas do segundo choque do petróleo e da crise da dívida, o Ppreps e vários outros programas contemporâneos constituíram espaços de intervenção na cena pública para um expressivo contingente de especialistas, muitas vezes alinhados ao pensamento democrático e aos movimentos sociais. Destas posições estes especialistas desempenhariam um papel decisivo na transição para a democracia e, na saúde, na constituição das bases sociais, políticas e institucionais daquele que viria a ser o Sistema Único de Saúde. 


\section{Os Primeiros Anos: o pPreps em IMPLANTAÇÃO (1976-1978)}

Decorrência de um acordo de cooperação exclusivamente voltado para o desenvolvimento de recursos humanos em saúde, o Programa de Preparação Estratégica de Pessoal de Saúde (Ppreps) procurou articular, como apresentado no capítulo anterior, o Ministério da Saúde e o Ministério da Educação e Cultura, entre outros órgãos federais e estaduais, tendo em vista a realização de três metas programáticas. Esta integração experimentaria dificuldades importantes, mas, de toda sorte, para tal empreitada foi previsto um orçamento considerado generoso, basicamente constituído por recursos provenientes do Ministério da Saúde e de outras potenciais fontes institucionais. Além disso, o Programa procurou mobilizar diferentes esferas de governo, os serviços de saúde e as universidades.

Da concepção ao arranjo e à realização efetiva do Programa, contudo, no contexto da segunda metade dos anos 1970, os idealizadores do Programa interagiram com um cenário que gradativamente se tornaria inesperado e, em alguma medida, hostil. Assim, os constrangimentos decorrentes da crise do final da década de 70, as discrepâncias nos diferentes níveis de desenvolvimento regional e institucional, o maior ou menor grau de adesão das universidades, entre outras variáveis, desenharam a cooperação técnica possível naqueles anos.

O objetivo desse capítulo será discutir as realizações e os maiores desafios enfrentados no desenvolvimento do Programa de Preparação Estratégica de Pessoal de Saúde, a partir de junho de 1976, quando o Ppreps entrou em 
operação, até 1978, ano em que se inicia o processo de avaliação e de renovação da Cooperação Técnica Opas-Brasil em Recursos Humanos e que conclui o que se pode considerar o seu primeiro ciclo de desenvolvimento. Nesta oportunidade, teve início um conjunto de alterações programáticas cujas implicações avançariam sobre a década seguinte. O capítulo se encerra com a explicitação destas novas orientações.

\section{PPREPS, PRIMEIRAS REALIZAÇÕES}

No capítulo anterior, indicamos que o Ppreps foi operacionalmente estruturado em torno de três eixos programáticos. O primeiro deles era diretamente referido às atividades de preparação de pessoal de nível médio e elementar, em volume proporcional às pretensões de expansão da cobertura da atenção previstas quando da implantação do Sistema Nacional de Saúde e do Programa de Interiorização das Ações de Saúde e Saneamento, Piass, ambos contemporâneos ao Ppreps. O segundo objetivo indicava a criação e o funcionamento de dez regiões docente-assistenciais de saúde, que corresponderiam a um universo entre 15 e 20 milhões de indivíduos atendidos. O terceiro, por fim, dava conta das ações de apoio às instâncias estaduais responsáveis pela condução das políticas e programas de desenvolvimento de recursos humanos em saúde.

Quanto ao primeiro objetivo as ações realizadas nos primeiros três anos de funcionamento do Programa, o balanço realizado pela equipe em 1978 - e portanto ao final do primeiro acordo de cooperação técnica - revelou um número considerável de pessoas capacitadas, em diferentes níveis e categorias. Foram ao todo cerca de 39 mil pessoas. No nível elementar, correspondendo às categorias de atendentes, agente comunitário, auxiliares de enfermagem e administração, foram quase 20 mil indivíduos capacitados. Os dados relativos às categorias de nível médio, englobando visitadores sanitários e as áreas técnicas de enfermagem, saneamento, laboratório, nutrição, administração, entre outras, indicaram o alcance de algo como 11 mil egressos. No nível superior, os números davam conta de 9 mil alunos capacitados para as funções de supervisão. Deste modo, metade dos egressos corresponderam ao nível elementar, $28 \%$ ao nível médio e pouco menos de $23 \%$ ao nível superior (Ppreps, 1979). 
Tais resultados foram obtidos mediante o desenvolvimento de 11 projetos de alcance estadual diretamente apoiados pelo $\mathrm{GTC}^{38}$. Os primeiros estados atendidos, ao longo do ano de 1976, foram o Piauí, Minas Gerais e o Rio Grande do Sul. Os demais, todos das regiões Norte e Nordeste do país, foram iniciados em 1977. Da mesma forma, foi a partir deste ano de 1977 que a produção do Programa atingiu números mais expressivos ${ }^{39}$.

Assim, observando-se os indicadores estritamente quantitativos, o Programa alcançou, em seus primeiros anos, resultados bem aquém das estimativas incluídas no projeto base, da ordem de uma variação entre 160 e 180 mil pessoas capacitadas. Todavia, os números alcançados foram expressivos. Este impacto foi provavelmente mais sensível nos estados de Minas Gerais, da Bahia, do Pará e Pernambuco, que atingiram patamares variando entre cinco e onze mil alunos, respectivamente para o caso pernambucano e mineiro. Segundo dados percentuais, Minas Gerais capacitou 28,5\% do total realizado pelo projeto; a Bahia, 19,3\%; o Pará, $13,7 \%$ e Pernambuco respondeu por $12,4 \%$.

A base operacional mobilizada para a realização dos vários cursos foram, sobretudo, as secretarias estaduais de Saúde dos estados federados, tal como especificado no projeto original. Como se discutirá com mais detalhes quando examinarmos as atividades orientadas para o terceiro objetivo do Programa, o programa promoveu a constituição ou designação, no interior das secretarias de Saúde de cada estado, de órgãos especialmente dedicados às atividades de desenvolvimento de recursos humanos. Na terminologia técnica do Ppreps, cada um desses órgãos passou a ser designado como Núcleo de Desenvolvimento de Recursos Humanos, ainda que eventualmente sem um ato formal de constituição.

Nos estados, segundo a percepção da própria coordenação, o Programa assumiu uma perspectiva que incluía: enfrentar o equacionamento das necessidades de recursos humanos, derivadas dos programas de extensão de cobertura, notadamente do Piass; dar continuidade às atividades já em andamento, as ditas "práticas tradicionais", de modo a não comprometer os programas já existentes; e, considerando esta experiência, introduzir e consolidar novos conceitos, práticas e instrumentos compatíveis às necessidades da população local.

38 Os estados atendidos foram: Amazonas, Pará, Maranhão, Piauí, Ceará, Rio Grande do Norte, Paraíba, Pernambuco, Bahia, Minas Gerais e Rio Grande do Sul.

39 Em 1976 formaram-se 4.217 pessoas, em 1977, foram 15.233 alunos, e, em 1978, 19.098. 
Desse modo, o Programa tinha como um imperativo realizar, como etapa prévia a cada projeto, um diagnóstico pretensamente exaustivo da realidade estadual. Assim, o Programa teria se constituído "num mosaico de projetos bastante aderidos aos respectivos contextos, tendo como traço comum a preocupação de interpretar a proposta inicial dentro de diferentes realidades estaduais". A mesma orientação contribuiria para promover junto a cada secretaria estadual de saúde e aos órgãos estaduais de planejamento maior atenção no que concerne aos diagnósticos de estoques e de necessidades em recursos humanos e às ações melhor programadas e menos "marginais" (Ppreps, 1979:30).

O desempenho em cada uma das unidades da federação foi reconhecidamente desigual, segundos os termos do Relatório Anual de 1978. Os fatores a serem considerados determinantes para um maior ou menor êxito, em cada iniciativa, diziam respeito: ao grau de mobilização e apoio político nas várias agências dos governos estaduais envolvidos na execução dos projetos; à capacidade de produzir um arranjo institucional amplo em torno da iniciativa; e a um maior ou menor grau de maturidade técnico-institucional nos setores mais diretamente ligados aos temas dos recursos humanos.

No caso, por exemplo, do Pará, considerado um projeto de desempenho acima da média, o mesmo mobilizou, além da Secretaria de Saúde, as secretarias de Educação e Administração, a Universidade Federal do Pará; a Escola Técnica Federal; a Fundação Serviço Especial de Saúde Pública (Fsesp); o Serviço Nacional de Aprendizagem Comercial (Senac); e a Escola de Enfermagem Magalhães Barata, subordinada ao governo estadual. Fora isso, as estruturas da Secretaria de Saúde já comportavam um departamento específico de desenvolvimento de recursos humanos, uma espécie de Núcleo de Desenvolvimento de Recursos Humanos, dotado de recursos materiais e de pessoal.

Ainda que o estado do Amazonas não tenha reunido um arranjo institucional semelhante àquele desenvolvido pelo seu vizinho, o Pará, seu Núcleo de Desenvolvimento de Recursos Humanos teve papel considerado de destaque na Secretaria de Saúde do estado, não apenas nos assuntos relativos aos recursos humanos, mas também naqueles relativos à extensão de cobertura, à regionalização dos serviços e à modernização administrativa.

Já as experiências desenvolvidas nos estados do Piaú, Rio Grande do Norte e Ceará foram consideradas importantes pelos técnicos do Grupo Técnico Assessor Principal (GAP) em face da inserção dos projetos no desenvol- 
vimento do Programa de Interiorização de Ações de Saúde e Saneamento, o Piass. No caso de Minas Gerais, onde Cesar Vieira havia até há pouco tempo atuado junto às áreas de planejamento da secretaria estadual de Saúde, o projeto promoveu o que seria uma renovação das atividades de desenvolvimento de recursos humanos, mediante uma maior integração das várias agências estaduais atuantes no setor. Para tanto, a principal articulação técnica foi realizada com os centros regionais de saúde e com a Assessoria de Planejamento da SES-MG, e a Escola de Saúde Pública da Fundação Ezequiel Dias.

Se estes foram os melhores resultados alcançados pelo programa, o relatório técnico de 1978 não deixou de registrar os projetos com desempenho abaixo da média. Entre os estados nessa condição, figuraram o Maranhão e a Paraíba, onde os Núcleos de Desenvolvimento de Recursos Humanos se viram comprometidos pelas condições institucionais das secretarias como um todo. No segundo caso, por exemplo, a principal dificuldade foi a existência de conflitos de competência técnico-administrativa entre a Assessoria de Planejamento, a Coordenação de Saúde e o Departamento de Recursos Humanos, além de sucessivas substituições do próprio secretário de Saúde.

Em vários estados, além das iniciativas voltadas para a preparação de pessoal de nível elementar e médio, os projetos apoiados pelo Ppreps, e, portanto, os núcleos estaduais de recursos humanos em saúde, atuaram diretamente na qualificação de pós-graduação em saúde pública, apoiando a realização do Programa Nacional de Cursos Descentralizados de Saúde Pública. Este programa, liderado pela Escola Nacional de Saúde Pública da Fundação Oswaldo Cruz, vinha sendo desenvolvido nos estados do Pará e do Rio Grande do Sul desde 1975, em caráter experimental. No ano seguinte foi implantado, com o apoio do Ppreps, na Bahia e Pernambuco. Em 1978 era, da mesma forma, realizado também no Amazonas (Ppreps, 1979: 4-11).

Componentes da própria equipe do GTC apoiavam a realização destes cursos descentralizados, eventualmente atuando como docentes em alguns dos módulos ou responsabilizando-se pela coordenação didática. Esta participação, todavia, segundo os próprios membros do grupo técnico, procurava respeitar a esfera de competência da Ensp no terreno do ensino de saúde pública, evitando a sobreposição de ações e os possíveis conflitos (Santana, 2005 e.2, f. 4).

Ainda no tocante ao primeiro objetivo, o Ppreps desenvolveu uma relação próxima de cooperação com o Núcleo de Tecnologia Educacional para a Saúde/Centro Latino-Americano de Tecnologia Educacional em Saúde 
(Nutes/Clates), da Universidade Federal do Rio de Janeiro ${ }^{40}$. Neste caso, tratava-se de complementar a própria capacidade técnica do Grupo Técnico Central (GTC), do Ppreps, principalmente no tocante à elaboração de recursos instrucionais, a criação de sistemas de treinamento, de currículos, além de realização em conjunto, nos núcleos de desenvolvimento de recursos humanos dos estados, de cursos de capacitação destinados à formação de supervisores e instrutores, entre outras atividades.

Entre os resultados alcançados por esta cooperação em particular, destaca-se a elaboração, em parceria com a Secretaria Técnica do Piass e a Secretaria de Recursos Humanos do Ministério da Saúde, de um guia curricular para atividades de capacitação de pessoal na saúde. Dirigido para a capacitação de visitadores sanitários e de atendentes de saúde pública, representou um esforço de sistematização conceitual e metodológica que pretendia ir de encontro às necessidades mais prementes nos estados (Ppreps, 1979: 20).

Particularmente com relação ao conjunto das atividades voltadas para o treinamento e o desenvolvimento de pessoal de saúde, segundo avaliação realizada então pelos próprios técnicos do Ppreps, o apoio federal às secretarias estaduais de Saúde foi considerado restrito ou limitado. Faltava, segundo estas análises, uma instância ou um mecanismo político-administrativo que empreendesse de forma sistemática a identificação de necessidades e problemas neste campo, especialmente se considerada a evolução dos serviços de saúde locais, integrando-as ao movimento de planejamento setorial em escala nacional. E que também realizasse uma efetiva articulação intersetorial, principalmente em âmbito interministerial.

$\mathrm{Na}$ ausência de tal instância ou mecanismo, os estados realizaram esforços mais ou menos isolados a fim de que fossem contempladas as necessidades de recursos humanos, especialmente tendo em vista o desenvolvimento do Piass. Nesse contexto, as secretarias estaduais procuraram priorizar projetos que atendessem às demandas mais imediatas de recursos humanos, resultantes dos programas de extensão de cobertura; procuraram também não paralisar instantaneamente as práticas já existentes, a fim de não provocar interrupções na oferta de pessoal de saúde aos serviços, mas favorecer a intro-

40 O Nutes/Clates, criado em 1972, era àquela altura um centro pan-americano da Opas. Esta vinculação orgânica com a organização intergovernamental permanecerá até 1983, quando o Clates, de duração relativamente efêmera, foi "nacionalizado", perdendo seu vínculo orgânico com a Opas, mantendo apenas a sigla Nutes e seu vínculo com a Universidade Federal do Rio de Janeiro (Opas, 1983). 
dução de mudanças graduais. Além disso, pretenderam promover novos conceitos, práticas e instrumentos que permitissem os gestores desenvolver serviços compatíveis às necessidades da população.

Com relação ao segundo objetivo, voltado para a instalação das regiões docente-assistenciais, foram quatro as iniciativas diretamente apoiadas pelo Programa no período compreendido entre 1976 e 1978. Como etapa prévia de lançamento desta linha de atuação realizou-se em Brasília um encontro nacional das várias iniciativas nacionais especialmente focadas no tema da integração ensino-serviço (Santana, 2006: e.2.; f.2) O primeiro projeto conveniado com o Ppreps destinava-se a apoiar a implementação, pela Faculdade de Medicina da Universidade Federal de Minas Gerais, do internato rural, ao mesmo tempo em que se promovia uma reformulação curricular. A área da implementação correspondia àquela do Centro Regional de Saúde de Montes Claros, então uma das mais dinâmicas regiões do processo de descentralização dos serviços de saúde empreendida pelo governo do estado a partir da gestão de Aureliano Chaves, iniciada em 1975 (Campos, 1995:219-238).

Um segundo projeto de integração docente-assistencial (IDA) apoiou a Universidade Federal da Pernambuco no desenvolvimento de iniciativas na área do município de Vitória de Santo Antão, em convênio com a Secretaria Estadual de Saúde. Nesta cooperação, pretendia-se apoiar a criação de modelos alternativos de atenção primária à saúde, a promoção da organização comunitária, além da adoção de sistemas de treinamento e supervisão de pessoal auxiliar e de estágios para estudantes das várias profissões da saúde.

No estado da Paraíba, foi iniciada uma cooperação considerada a mais ambiciosa. Seus componentes mais importantes envolveram a revisão dos currículos de enfermagem, medicina, farmácia e bioquímica; a implantação de estágios rurais integrados, a criação do curso de especialização em administração e planejamento de sistemas regionais de saúde; a implantação de programas de educação continuada e de uma rede de informação científica e tecnológica. Entre as instituições participantes incluíam-se o Centro de Ciências da Saúde, da Universidade Federal da Paraíba e a Secretaria de Estado de Saúde, as quais estreitaram relações com os órgãos estaduais do Instituto $\mathrm{Na}$ cional de Assistência Médica da Previdência Social, o Inamps.

O último projeto a entrar na pauta de cooperação técnica do Ppreps no período desenvolveu-se junto ao Centro de Ciências da Saúde da Universidade Federal do Piauí. Suas atividades consistiram na realização de um seminário 
e de avaliação das experiências na universidade que pudessem ser consideradas inovadoras, tendo em vista as propostas de integração docente-assistencial. Além disso, o projeto procurou também desenvolver condições favoráveis para a implantação da IDA no estado, tais como a criação de mecanismos de articulação entre a universidade e a rede de serviços, programação de estágios de graduação nos cursos de medicina e enfermagem, entre outras.

De maneira geral, considerou-se que a linha de atuação em torno dos projetos IDA enfrentou as mais sérias dificuldades do Programa. Estas decorreram, de início, de sua frágil sustentação institucional, conseqüência de uma insipiente institucionalização do recém-criado Sistema Nacional de Saúde. Outras dificuldades referiam-se à existência, no interior das universidades, de grupos refratários às reformas, assim como de uma tradição profissional que não estimulava uma abordagem de cunho interdisciplinar, que contemplasse especialmente as ciências sociais. Isto significava que, na altura de 1978, a estratégia de constituição das regiões docente-assistenciais fosse considerada uma proposição em larga medida prematura frente ao grau de institucionalidade do próprio sistema de atenção à saúde, e cujos resultados deveriam ser necessariamente "mais demorados e custosos". Na prática, isto determinou que, quando da ocorrência de cortes orçamentários na programação inicial do Ppreps, os projetos IDA tenham sido os mais diretamente afetados. Não só se restringiu a um terço o número de projetos a serem apoiados como se viram reduzidos os recursos disponíveis para o apoio a cada um deles (Ppreps, 1979: 12-13). Como alternativa, o GTC e a Comissão de Coordenação estabeleceram que a cooperação deveria se ater às iniciativas já em andamento, concentrando-se em agregar maior capacidade de transformação àquelas mais promissoras.

Mesmo neste âmbito, mais restrito, os projetos enfrentavam percalços quando se tratava de ajustar os empreendimentos já em curso aos objetivos da IDA, tal como estabelecidos no projeto base. De outra forma, as práticas vigentes nas universidades tendiam a amenizar os possíveis impactos transformadores das proposições introduzidas pela IDA, seja relegando-as a uma dimensão estritamente formal, seja confinando-as a aspectos puramente experimentais. Mesmo os grupos mais inovadores tenderiam, por outro lado, a se manter circunscritos aos seus domínios disciplinares e departamentais, reproduzindo as práticas não integradas (Ppreps, 1979: 14).

A limitação do volume de recursos, a concentração das áreas de atuação da cooperação técnica em poucos projetos, além das dificuldades de ordem institucional, poderiam, segundo a avaliação do grupo técnico, compro- 
meter severamente os progressos para o desenvolvimento da integração entre a docência e as práticas concretas de atenção à saúde no país, um objetivo cuja relevância era reiterada. As correções de rumo preconizadas apontavam então para a necessidade de enfocar o conjunto do ensino de terceiro grau em Saúde e oferecer cooperação para diferentes instituições, identificando iniciativas e situações adequadas para se oferecer apoio.

Mais do que isso, a própria organização da atuação do Ppreps a partir de projetos foi criticada. Dada a complexidade das ações de IDA, o longo período necessário para a sua maturação, em um ambiente institucional extremamente dinâmico, recomendava-se adoção de formas mais permanentes de atuação, ainda que flexíveis e capazes de uma melhor resposta a oportunidades não previsíveis e, portanto, de maior aderência à realidade (Ppreps, 1979: 32).

Todavia, paralelamente, na altura de finais da década de 1970, a Opas e a Fundação Kellogg estabelecem uma parceria na condução dos projetos de integração docente-assistencial na região das Américas. Por este entendimento, caberia à Opas operar como instância de assistência técnica a todos os projetos apoiados financeiramente pela fundação filantrópica norte-americana. No Brasil, a experiência do Ppreps no apoio direto aos projetos IDA o tornava especialmente credenciado para esta função. Esta linha de colaboração teria profundas implicações no desenvolvimento de iniciativas de IDA ao longo das décadas seguintes, como será discutido nos próximos capítulos (Santana, 2006: e.2.; f.4).

No que diz respeito ao terceiro objetivo, relativo ao fortalecimento das instâncias estaduais dedicadas ao tema dos recursos humanos para a saúde, o principal resultado alcançado pelo Programa foi, exatamente, imprimir maior destaque ao tema dos recursos humanos como componente das políticas de saúde em âmbito nacional e estadual. Neste sentido, a criação dos núcleos estaduais de desenvolvimento de recursos humanos, integrados às secretarias de saúde dos estados, era uma estratégia considerada fundamental, na medida em que propiciava, nesta esfera, a instituição de uma referência tanto para os aspectos político-administrativos quanto pedagógicos.

A equipe do GTC procurou promover, como já sinalizado, maior articulação intersetorial no interior dos executivos estaduais. Pretendeu também estabelecer uma maior proximidade entre as várias agências federais envolvidas com a temática da formação e capacitação de pessoal em saúde. Da mesma forma, buscou estreitar laços político-institucionais entre os âmbitos federais e estaduais, sobretudo no que se refere a planejamento e programação 
setoriais de saúde e educação. Quanto a esta dimensão, o Relatório Anual de 1978 indicava que estes esforços integradores obtiveram êxito sensivelmente maior nas relações em âmbito estadual.

Essas dificuldades nas esferas federais e a maior facilidade de trânsito no âmbito dos estados aparentemente contribuíram para a afirmação daquele que seria um dos sentidos desejados da própria cooperação técnica Opas-Brasil: embora prevalecesse o desejo de alguma centralização normativa, por parte do GTC, toda a plataforma operacional estava desenhada tendo em vista um gradual processo de descentralização. E mais, a cooperação técnica representava essencialmente a promoção da autonomia local, de uma forma que tanto mais o Ppreps fosse eficiente, mais seria tecnicamente dispensável.

De toda forma, ainda segundo o Relatório, a montagem do arranjo institucional em torno do GTC teria sido

viabilizada a duras penas, numa fase em que eram muito estreitas as linhas de dependência técnica e financeira entre o Ministério e Secretarias de Saúde de um lado e Ministério e Secretarias de Educação e Universidades de outro. Além disso, a permeabilidade que se encontrou a nível estadual para rearticular tais instituições não foi correspondida na mesma proporção no nível central.

E o relatório conclui:

pode parecer paradoxal ser mais fácil articular Saúde e Educação nos Estados que no plano federal mas isto, de fato, a experiência do Ppreps comprova. A coordenação entre os Ministérios, relativa ao desenvolvimento de recursos humanos para a saúde foi apenas incipiente. (Ppreps, 1979: 26)

Essa matriz institucional não foi totalmente elaborada a partir de um arranjo prévio. Em certo sentido, ela foi negociada ao longo do próprio desenvolvimento da cooperação técnica, em um processo em que dependeu da percepção política e gerencial das lideranças do Ppreps na avaliação dos vários cenários e circunstâncias. Como se verá no próximo capítulo, as dificuldades vivenciadas no que concerne a uma maior articulação institucional entre os órgãos federais iriam requerer, como pauta futura, a montagem de novos arranjos institucionais, a mobilização de novos atores.

No que concerne ao financiamento do Programa, até dezembro de 1978, ao final da vigência do primeiro acorde de cooperação técnica, havia 
sido aportado ao Programa um volume global aproximado de Cr\$39.000.000,00 (trinta e nove milhões de cruzeiros), ou algo como $\mathrm{R} \$ 15.500 .000,00$ (quinze milhões e quinhentos mil reais), em valores corrigidos. Este volume correspondeu a uma distribuição de Cr\$7.000.000,00 $(\mathrm{R} \$ 5.500 .000,00)$, em 1976; Cr\$ 16.000.000,00 (R\$ 9.000.000,00), em 1977; e Cr\$16.100.000,00 ( $\mathrm{R} \$ 6.400 .000,00)$, para o ano de 1978. Dos recursos transferidos durante todo o período, metade foi destinada ao treinamento e desenvolvimento de recursos humanos; cerca de $16 \%$ para a integração docenteassistencial e cerca de $34 \%$ para os encargos da coordenação. A distribuição anual dos recursos indica em que medida o último ano deste primeiro período de operação do Ppreps registrava uma importante redução no volume de recursos alocados no projeto. Os anos do endividamento externo fácil estavam chegando ao fim e, em certa media, desferindo o tiro de misericórdia na política econômica triunfalista do regime militar brasileiro.

Os valores globais, que não incluíam os recursos alocados como contrapartida pelas secretarias estaduais e outros parceiros, equivaliam a apenas $35,1 \%$ daqueles inicialmente previstos. Uma redução gradativa do valor real dos repasses anuais parecia ser, então, aos olhos da coordenação do Programa, uma tendência duradoura já a partir de 1977, quando as contas públicas nacionais passaram a refletir mais intensamente as vicissitudes da crise global de finais da década (Ppreps, 1979: 25).

Limitações orçamentárias, aliadas às diferentes conjunturas políticas e às disparidades nos níveis de desenvolvimento local contribuíram para resultados considerados apenas parciais, sobretudo no que se refere ao desenvolvimento dos projetos IDA e tendo em vista as ambiciosas metas quantitativas previstas no projeto original.

Estes resultados, contudo, não são indicadores seguros. O legado destes primeiros anos é dificilmente redutível aos seus efeitos quantitativos imediatos. A médio prazo, a cooperação contribuiria decisivamente para a própria constituição dos recursos humanos em saúde como domínio de saberes e práticas sociais e âmbito de formulação e implementação de políticas públicas. Para alguns de seus contemporâneos, os primeiros anos do Ppreps foram responsáveis por mobilizar opiniões, interesses, vocações e atores até então mais ou menos dispersos.

Foi, por exemplo, por iniciativa do Ppreps que o tema da integração entre a formação profissional e os serviços de atenção à saúde foram retomados, em 1978, no âmbito dos debates na Associação Brasileira de Educação 
Médica (Santana, 2005, e.1, f.3). Na visão da equipe central do Ppreps, em artigo publicado em 1980, o principal resultado alcançado nos primeiros anos da iniciativa foi tornar visível, no plano das políticas de saúde e tanto em âmbito federal quanto estadual, aquele que seria o caráter global do desenvolvimento de recursos humanos em saúde e a "subordinação dos seus componentes à evolução do todo, dentro do contexto sócio-político e administrativo em que se desenvolve" (Macedo, Santos \& Vieira, 1980: 73-74).

Em outro exemplo deste tipo de atuação, durante o mês de outubro de 1979, a equipe do Ppreps estaria diretamente mobilizada na realização do I Simpósio sobre Política Nacional de Saúde da Câmara dos Deputados. Em um evento de ampla repercussão nos meios especializados e políticos, o tema dos recursos humanos seria objeto de uma conferência de Carlyle Guerra de Macedo que, em larga medida, explicitava as orientações assumidas na orientação do programa e da própria cooperação técnica (Brasil. Câmara dos Deputados, 1980).

A inserção do Ppreps e da equipe do seu GTC no nascente movimento de crítica e reforma das instituições e das práticas de saúde no país, além de imprimir maior visibilidade ao tema do desenvolvimento de recursos humanos, suscitava que, em várias ocasiões, o Programa operasse como espaço para o debate de pautas e para a formulação de estratégias do próprio movimento. Deste modo, por exemplo, uma reunião no edifício sede da representação da Opas no Brasil, em Brasília, de amplitude nacional, organizada com o propósito da realização do Seminário Nacional sobre Oferta e Demanda de Pessoal de Saúde, constituiu oportunidade para a criação da Associação Brasileira de Saúde Coletiva, a Abrasco (Santana, 2005: e.2, f.5; Vieira, 2005: e.1, f.1).

Estes "propósitos invisíveis" de parte da atuação do Ppreps eram também componentes de um movimento de gradativo transbordamento dos próprios objetivos originais do programa em direção a temas como as políticas globais de saúde e à organização dos serviços de atenção. Há que se ter claro, no entanto, que este transbordamento era também, por seu turno, uma manifestação da forma com que se conceituava o desenvolvimento de recursos humanos. Em uma perspectiva integradora, este somente seria completamente compreensível se relacionado às formas de identificação das necessidades coletivas em saúde, de organização dos serviços e de realização do trabalho em saúde - como parte indissociável, portanto, das políticas de saúde, no âmbito de uma formação social concreta e dos seus modos de produzir e 
compartilhar bens e serviços. Nos dizeres do primeiro coordenador do Ppreps, Carlyle Guerra de Macedo, eram

os componentes do processo de desenvolvimento de recursos humanos: em primeiro lugar a identificação das necessidades (...) e tendo em contas a disponibilidade de conhecimento, de tecnologia e de recursos em uma sociedade concreta, (...) os tipos de serviço necessários e a maneira de organizá-los (...) e a partir daí, (...) a identificação das necessidades de recursos humanos, por tipos, por quantidade, e sobre estas bases o desenho de programas para formação (...) e dos sistemas para sua adequada utilização.

E mais adiante:

Inseparável da política de saúde (...) e, por sua vez, inseparável da política social e da política global de desenvolvimento, os recursos humanos para a saúde não podem ser analisados senão neste contexto mais amplo de todo o desenvolvimento social; de todo o desenvolvimento do país. (Brasil. Câmara dos Deputados, 1980: 64-65)

De qualquer modo, paulatina e consistentemente - como se discutirá com mais detalhes no próximo capítulo -, temáticas como a organização global dos serviços de saúde e o planejamento em saúde se fizeram mais e mais presentes, de maneira que os "propósitos invisíveis" terminariam por assumir também a sua face oficial e se exprimir nos próprios documentos formais da cooperação. No segundo semestre de 1978, quando que se aproximavam do seu término, simultaneamente, o governo Geisel e o período de vigência do Acordo de 1973, a equipe do GTC e os representantes das instituições signatárias realizaram negociações com vistas à renovação do termo de cooperação.

Simultaneamente, em um esforço no sentido de ampliar as bases institucionais para uma ação cooperativa no desenvolvimento de recursos humanos em saúde, foi instituído, em setembro de 1978, um grupo de trabalho interministerial para a realização de um diagnóstico de situação e a proposição de ações conjuntas no terreno da educação superior e técnica. Coordenado pelo Departamento de Assuntos Universitários do MEC e contando com componentes indicados pela Secretaria de Planejamento da Presidência da República (Seplan) e pelos ministérios da Educação e Cultura, do Trabalho, da Saúde e da Previdência e Assistência Social, o grupo de trabalho deveria terminar suas atividade em 90 dias - meados de dezembro -, portanto a tempo de subsidiar a celebração de um novo acordo. Todavia, o relatório do grupo de 
trabalho seria finalizado apenas em março de 1979. Sua publicação tardaria ainda mais, ocorrendo em $1981^{41}$. Neste novo contexto, como se verá no próximo capítulo, seriam melhores as condições políticas e institucionais para uma maior articulação.

Quanto a este aspecto, vale reiterar que apenas em finais de 1979 o Ministério da Educação e Cultura Saúde iria designar os seus representantes junto ao Grupo Técnico Central do Ppreps (Santana, 2005: e.1, f.3). A partir deste ano, passariam a integrar a equipe do Ppreps, por designação da Secretaria de Ensino Superior do MEC, o médico piauiense José Paranaguá de Santana, dedicado aos temas do ensino médico, a educadora Regina Coeli Nogueira e o administrador Francisco Lopes, indicado pela Secretaria Geral do Ministério da Saúde (Santana, 2005, e.1, f.3).

Regina Nogueira, educadora de formação, era uma especialista em legislação e organização do ensino técnico de nível médio e sua presença na equipe resultou de uma demanda expressa de Izabel dos Santos. Francisco Lopes, administrador, tornara-se um técnico especializado na elaboração e implantação de planos de carreira, cargos e salários. José Paranaguá de Santana, médico pela Universidade de Brasília, havia participado da coordenação do Projeto Planaltina, voltado para a implantação de uma experiência de medicina comunitária no entorno de Brasília, uma iniciativa da UnB, do governo do Distrito Federal, do Funrural e Fundação Kellogg, sob a coordenação de Frederico Simões Barbosa. Em meados da década de 1970, José Paranaguá de Santana havia atuado na Secretaria de Ensino Superior, do Ministério da Educação e Cultura (MEC), quando apoiava diretamente o funcionamento da Comissão Nacional de Residência Médica e os processos de regulamentação da residência em Medicina Preventiva e Social.

Neste mesmo ano, as transferências financeiras a cargo do MEC tornarse-iam também objeto de um compromisso formal (Opas/Brasil, 1979: 6-7). A integração do Ministério da Previdência e Assistência Social seria ainda mais tardia, em março de 1980. Esta maior articulação intersetorial, porém, tal como será discutido no próximo capítulo, será ela mesma expressão e resultado de uma cooperação técnica renovada em sua orientação (Opas/Brasil, 1980: 7).

${ }_{41}$ Compunham o grupo de trabalho Edson Machado de Souza e Carlos Marć́lio de Souza, pelo MEC; Sólon Magalhães Vianna e Leandro Amaral Lopes, pela Seplan, Stella Winge e Pedro Luis Tauil, pelo MS; Hugo Alqueres e Doriane Calvet, pelo MPAS; e, ainda, José Alberto Couto Maciel e José Maciel Neves, pelo MT. José Paranaguá de Santana foi um dos que apoiaram diretamente a elaboração do documento. E é possível mesmo que o funcionamento do GT tenha propiciado uma maior presença do MEC como ente constituinte do Ppreps. 
O ano de 1979 registraria também uma primeira retirada na equipe do Ppreps. No primeiro semestre, Danilo Prado Garcia dirigiu-se a Paris para um período de estudos em economia da saúde, custeados com a ajuda de uma bolsa de estudos oferecida pela OMS. Em inícios de 1981, ele estaria de volta para um período de assessoria ao Ministério da Previdência e Assistência Social (Garcia, 2005, e.1, f.1).

De qualquer modo, entre 21 e 29 de dezembro de 1978, Paulo de Almeida Machado, Ministro da Saúde, Euro Brandão, Ministro da Educação e Cultura e Héctor Acuña, Diretor da Opas, firmaram o Termo Aditivo ao Acordo para um Programa Geral de Desenvolvimento de Recursos Humanos para a Saúde no Brasil. Neste documento, os compromissos básicos firmados cinco anos antes ficavam prorrogados até finais de dezembro de 1986 - por mais oito anos, portanto -, o que significava um importante alongamento do prazo de vigência da cooperação.

Este novo instrumento alterava também algumas cláusulas substantivas presentes no acordo original e seus documentos complementares. Todavia, as incertezas e os vazios de poder mais ou menos característicos dos períodos de transição, impuseram uma certa demora na efetiva implementação dos novos encaminhamentos. Apenas em agosto de 1979, durante o curto período de Mário Augusto Castro Lima no exercício da pasta da Saúde, um instrumento de cunho operacional foi firmado entre as partes signatárias, ratificando os planos de ação de cada uma das áreas de saúde e educação e possibilitando uma retomada mais efetiva dos trabalhos. Contudo, na memória de pelo menos um dos participantes da equipe central do Programa, somente com a posse de Waldyr Mendes Arcoverde no Ministério da Saúde, em 30 de outubro de 1979, o tema dos recursos humanos em saúde voltaria a figurar com alguma centralidade na pauta de prioridades ministeriais (Santana, 2005: e.1, f.3).

O Termo Aditivo ao Acordo, de 1978, e o instrumento complementar de 1979 reiteravam alguns dos macrobjetivos presentes no documento de 1973 e não completamente assumidos pela agenda do Ppreps. Incluíam também temas apenas parcialmente enfrentados e ainda outros até então abordados de modo mais ou menos informal. Os novos termos retomavam, em certa medida, parte dos objetivos gerais formulados pelo Grupo de Trabalho sobre Recursos Humanos, de $1974^{42}$. De outra parte, ajustavam os marcos formais

$\overline{42}$ Sobre este grupo de trabalho e o seu relatório, ver capítulo 2. 
ao desenvolvimento concreto da iniciativa ao longo de seus primeiros três anos. A Fundação Oswaldo Cruz deixava de figurar como entidade intermediadora dos recursos e responsável pela sua administração contábil.

Desta forma, os novos compromissos reafirmavam o objetivo de desenvolver ações orientadas para o planejamento e desenvolvimento dos recursos humanos, nos marcos de um plano geral de desenvolvimento de recursos humanos para a saúde; pretendiam o aperfeiçoamento de processos e mecanismos voltados para a integração docente-assistencial; e propugnavam pela melhoria da qualidade no ensino, apoiando iniciativas de revisão de currículos, a adoção de técnicas pedagógicas inovadoras e um estímulo direto à produção e oferta de informação atualizada. Quanto a este último aspecto, tornaram explícita a necessidade de uma articulação mais sistemática com o Centro Latino-Americano de Tecnologias Educacionais em Saúde (Nutes/Clates) e a Biblioteca Regional de Medicina (Bireme), instituições administrativamente vinculadas à $\mathrm{Opas}^{43}$. Vale ainda ressaltar que os documentos, em várias passagens e sintomaticamente, abandonam a expressão assistência técnica, substituindo-a pela de cooperação. Por outro lado, os novos documentos conferiam um maior destaque às ações orientadas para o fortalecimento das áreas de ensino e pesquisa de pós-graduação, em especial em saúde coletiva, inclusive renovando a necessidade de estabelecimento de um programa de bolsas de estudos tanto no país como no exterior.

Foram reformatadas as instâncias de coordenação e de condução executiva. A Comissão de Coordenação passou a ser composta por oito representantes, sendo três para cada um dos ministérios e dois de escolha da Opas, todos a serem designados mediante portaria interministerial. O Grupo Técnico Central passou a receber a denominação de Grupo Assessor Principal (GAP) e a ser integrado por três assessores principais, admitindo-se porém a constituição de uma equipe da assessores especiais, a ser composta segundo os recursos transferidos para o projeto por cada uma das pastas envolvidas. (Opas/ Brasil, 1978: 10). Por outro lado, os documentos definiam os montantes a serem diretamente transferidos à Opas, segundo planos de trabalho previamente aprovados.

43 A Bireme, desde 1982 Centro Latino-Americano e do Caribe de Informação em Ciências da Saúde, foi instituída em 1967, em São Paulo, como um centro pan-americano especializado. Ligada à Opas, mantém esta condição até os dias de hoje. Para uma história da Bireme, ver Pires-Alves, 2005 e Silva, Ferla \& Gallian, 2006. 
Em março de 1980, um novo termo aditivo introduziria um novo e fundamental elemento no arranjo institucional de sustentação da cooperação técnica em recursos humanos e de seu principal programa. O Ministério da Previdência e Assistência Social, à época ocupado pelo gaúcho Jair de Oliveira Soares, passou a ser um dos entes signatários do Programa e um dos seus financiadores diretos. Esta nova base institucional refletia, no domínio do desenvolvimento dos recursos humanos em saúde, as tentativas que à época eram empreendidas com o intuito de estabelecer mecanismos de integração entre as principais áreas do executivo federal envolvidas com a atenção à saúde. Àquela altura, em certo sentido, generalizava-se a crítica à dicotomia entre saúde pública e a prestação de serviços de medicina curativa, sobretudo por meio da assistência médica previdenciária, materializada na própria existência das pastas ministeriais distintas e em alguma medida ratificada quando da criação do Sistema Nacional de Saúde, em 1975.

Este relativo consenso terminaria por impor a necessidade de novas configurações institucionais. Na passagem da década, a necessidade de uma nova base institucional na prestação de serviços de atenção à saúde terminaria por produzir, no caso da cooperação técnica Opas-Brasil e do Ppreps, em particular, uma radical ampliação dos seus objetos. 


\section{Cooperaçãotécnica em Novas Bases}

(1979-1988)

Com a co-autoria de Janete Lima de Castro*

Em 1978, iniciou-se o processo de renovação do Acordo para um Programa Geral de Desenvolvimento de Recursos Humanos para a Saúde no Brasil, assinado cerca de três anos antes pelo governo brasileiro e pela Opas. Este ciclo de reformulação da cooperação técnica Opas-Brasil em RH somente se encerraria em 1980. Ao final deste período, o Ministério da Previdência e Assistência Social se tornaria um novo componente de sustentação institucional do Acordo e teria início um conjunto de mudanças importantes na matriz original do Programa, tanto no que concerne aos objetivos da cooperação técnica na área de formação de recursos humanos para a saúde, quanto à sua estrutura político-administrativa, inclusive em relação à composição do Grupo Técnico Central, a sua principal instância executiva.

Estas mudanças, registradas em documentos institucionais e nos depoimentos dos personagens que tomaram parte do processo, conduziram o Programa a experiências institucionais inovadoras. Entre elas, a elaboração do Programa Nacional de Serviços Básicos de Saúde, o Prev-Saúde; o desenvolvimento daquele que se tornaria amplamente conhecido como o Projeto Larga Escala; a introdução e implementação de um subprograma especialmente voltado para a formulação de políticas e ao planejamento em

* Janete Lima de Castro é professora associada da Universidade Federal do Rio Grande do Norte (UFRN) e enfermeira da Secretaria Municipal de Saúde de Natal/RN. Mestre em Administração e doutoranda no Programa de Pós-Graduação em Educação na UFRN, é coordenadora do Observatório de Recursos Humanos do Nesc/UFRN. 
Ciência \& Tecnologia em Saúde; e a realização, mais tarde, a partir de 1987, do Curso de Aperfeiçoamento em Desenvolvimento de Recursos Humanos de Saúde, o Cadrhu.

Essas mudanças e inovações na cooperação representaram também o duplo movimento de afirmar e promover a institucionalização da frente de trabalho dedicada à preparação de pessoal de saúde de nível médio, bem como de ampliar a própria cooperação em direção a outros temas referentes à organização e à infra-estrutura dos serviços de atenção à saúde.

Neste capítulo, serão pontuados estes novos domínios de atuação da cooperação inaugurados, em 1978/80, com a renovação do Acordo. Todavia, serão, sobretudo, discutidos os seus desdobramentos e experiências mais importantes no terreno da formação de recursos humanos em saúde, até a conjuntura imediatamente anterior à VIII Conferência Nacional de Saúde e da Conferência Nacional de Recursos Humanos em Saúde. Estes dois eventos, nos marcos do governo de transição democrática, inauguram um ciclo de aceleração do processo da Reforma Sanitária que alteraria definitivamente a base institucional em que se desenvolvia a cooperação técnica Opas-Brasil.

\section{A REORGANIZAÇÃO DA COOPERAÇÃO TÉCNICA OPAS-BRASIL}

No final de 1978 encerrava-se a vigência do primeiro Acordo OpasBrasil em RH para a Saúde. Em linhas gerais, o ambiente não se mostrava particularmente favorável para a abertura das rodadas de negociação com vistas à sua renovação. No plano econômico se tornavam mais e mais nítidos os impactos da crise internacional e das suas implicações nas contas públicas brasileiras. No plano político, a sucessão do governo Geisel dava início às costumeiras incertezas quanto à continuidade de políticas, programas e processos. Mais do que isso, tornava visíveis as fissuras entre as forças a favor do regime ditatorial e aquelas mais favoráveis a uma abertura política.

Graças ao apoio do então presidente da República Ernesto Geisel, o general João Baptista Figueiredo foi eleito em reunião do Colégio Eleitoral em outubro de 1978, tomando posse em março do ano seguinte. Chefe do Gabinete Militar, durante a gestão de Médici e chefe do Serviço Nacional de Informação (SNI) no governo que se encerrava, Figueiredo, uma vez eleito, teve como principais desafios, por um lado, conter a chamada Linha Dura das 
Forças Armadas e, de outro, sob pressão dos movimentos sociais, avançar no processo de uma abertura política, denominada, segundo o jargão do próprio regime, "lenta e gradual". Seu governo experimentaria o aprofundamento da crise econômica. Os primeiros anos da década de 1980 apresentariam indicadores de PIB negativos, estagnação econômica e inflação crescente (Fausto, 2000).

A assinatura de um novo acordo de cooperação entre a Opas e o governo brasileiro ocorreu nos últimos dias dezembro de 1978, ao término do governo Geisel, somente. Todavia, como indicado no capítulo anterior, as atividades da cooperação pouco avançaram durante a primeira metade de 1979, no período de gestão do Ministro da Saúde Mário Augusto Castro Lima, uma indicação de Antônio Carlos Magalhães, liderança governista na Bahia e então recém-eleito para um segundo mandato como governador do estado. Somente em outubro de 1979, com a saída de Castro Lima do Ministério da Saúde e a posse de Waldyr Mendes Arcoverde, a cooperação passou a vivenciar perspectivas políticas relativamente mais promissoras.

O piauiense Waldyr Arcoverde assumia a pasta a partir de uma indicação de Jair Soares, que passaria a ocupar o Ministério da Previdência e Assistência Social, depois de deixar o governo do Rio Grande do Sul, onde Arcoverde havia ocupado até poucos meses antes a Assessoria de Planejamento da Secretaria Estadual de Saúde. Arcoverde mantinha também relações de afinidade política com Petrônio Portela, Ministro da Justiça, e eram ambos próximos do também piauiense Carlyle Guerra Macedo. Além disso, havia por parte da equipe da cooperação expectativas de que o projeto recuperasse o apoio e o ritmo anterior, mobilizando as alianças que havia constituído naqueles estados onde os trabalhos tinham alcançado bons resultados, graças ao financiamento e o aporte técnico proporcionado pelo grupo técnico às secretarias de saúde $\mathrm{e}$ às universidades (Macedo, 2005: e.1, f.3; Escorel, 1998: 171).

No entanto, a situação econômica do país se agravava. A pretendida combinação de crescimento econômico com controle da inflação tornava-se cada vez mais distante, até que, em fins do ano de 1980, restringiu-se a expansão da moeda, os investimentos nas empresas estatais foram drasticamente reduzidos, as taxas de juros se elevaram e, ao mesmo tempo, os novos investimentos privados tornavam-se escassos (Fausto, 2000: 502).

Se, com o II Plano Nacional de Desenvolvimento de 1975, o regime autoritário pretendia incorporar à sua agenda as políticas sociais - no nosso caso em particular a da saúde -, a conjuntura de crise dos anos 1979/80 finais exigiria um novo esforço racionalizador, tendo em vista restrições de natureza 
econômica e o próprio avanço das oposições. Para tanto, foi preciso mobilizar a capacidade e boa parte de uma imaginada neutralidade técnica representada por equipes de especialistas sediadas nas universidades e por aqueles como a do Ppreps, constituídas sob a égide de um organismo intergovernamental. Isto significava também franquear maiores espaços institucionais ao nascente movimento social envolvido com a reforma dos sistemas de atenção à saúde.

Em outubro de 1979, sob os auspícios da Comissão de Saúde da Câmara dos Deputados e com o apoio do Programa de Cooperação Técnica Opas-Brasil, realizou-se o I Simpósio sobre Política Nacional de Saúde. Este evento reuniu, na capital da República e no Congresso Nacional, delegados de todo o país e boa parte dos profissionais mais engajados no movimento sanitário brasileiro e procurou discutir temas considerados chave para uma abordagem integral e articulada das questões de saúde no contexto da reabertura democrática. Entre os temas abordados figuraram: perspectivas das políticas públicas de saúde no Brasil; saúde e desenvolvimento econômico social; hierarquização, descentralização e regionalização dos serviços de saúde; privatização e estatização; e, vale destacar, contemplaram de modo destacado o tema do desenvolvimento de recursos humanos para a saúde (Brasil. Câmara dos Deputados, 1980).

Nesse contexto modifica-se a composição do Grupo Técnico Central, desde 1978 renomeado Grupo Assessor Principal (GAP), assim como da Comissão de Coordenação da Cooperação. Em finais de 1979, ingressaram, na equipe executiva do GAP, o médico piauiense José Paranaguá de Santana, a educadora Regina Coeli Nogueira e o administrador Francisco Lopes, todos indicados pelo Ministério da Educação e Cultura.

Em março de 1980, mediante o Segundo Termo Aditivo ao Acordo, e a assinatura de Jair Soares, o Ministério da Previdência e Assistência a Social (MPAS) passou a integrar a base institucional de sustentação do Acordo, somando-se à Opas e aos ministérios da Saúde e da Educação e Cultura. Neste mesmo ano, integraram-se à equipe do GAP os médicos Alberto Pellegrini Filho, pelo Ministério da Previdência e Assistência Social e Roberto Passos Nogueira, indicado pela Secretaria de Recursos Humanos do Ministério da Saúde.

Foi nesse contexto e com forte componente de simultaneidade que os ministérios da Saúde e da Previdência e Assistência Social mobilizaram a cooperação técnica Opas-Brasil para a constituição de um grupo técnico e elaboração daquele que seria o Programa Nacional de Serviços Básicos de Saúde, e que se tornou amplamente conhecido no setor pela sigla Prev-Saúde. 
Como a própria sigla expressa, este programa se constituiu em uma proposta de articulação objetiva entre as áreas de saúde pública, tradicionalmente sob a responsabilidade da pasta da saúde, e os serviços de assistência médica até então sob a órbita do Instituto Nacional de Assistência Médica da Previdência Social vinculado ao MPAS. Concebido de forma a propiciar atendimento universal, privilegiando a atenção básica em saúde, o Prev-Saúde alinhava-se às recomendações da Assembléia Mundial de Saúde, de 1977 e da Conferência Internacional sobre Cuidados Primários de Saúde, realizada no ano seguinte, em Alma-Ata, capital do Cazaquistão, república da então União Soviética.

Os principais objetivos do Prev-Saúde eram amplos: enfrentar o problema da cobertura dos serviços básicos de saúde, de forma a atingir o conjunto da população; promover um reordenamento do setor público, estimulando maior articulação entre as esferas federal, estadual e municipal; aumentar a produtividade, via racionalização da oferta de serviços disponíveis; e promover a melhoria das condições sanitárias do ambiente, com a implantação de sistemas de abastecimento de água e esgoto, particularmente nas áreas com maior prevalência de endemias e maior densidade populacional. Previa-se um gradual avanço no atendimento as áreas mais carentes economicamente, sobretudo periferias urbanas e zonas rurais; o controle de doenças transmissíveis, especialmente diarréias infecciosas; a prevenção de cáries dentárias e da desnutrição; e o atendimento eqüitativo para grupos de maior risco, em particular, mulheres gestantes e crianças. Pretendia-se, por fim, como componente integrado desta pauta abrangente, desenvolver a infra-estrutura institucional e dos recursos humanos.

No componente de RH, visava-se, no que concerne às profissões de nível superior, promover a formação e utilização preferencial de pessoal generalista. Da mesma forma, pretendia-se ampliar a preparação de um contingente de pessoal auxiliar nos níveis médio e elementar. Visava também promover as condições institucionais e a formação de pessoal em nível gerencial de modo a permitir um melhor planejamento e gestão do trabalho em saúde (Prev-Saúde, [1981]).

O novo programa definia o médico generalista como sendo aquele profissional que, dispondo de auxiliares adequadamente treinados, estaria apto a resolver os casos epidemiologicamente mais relevantes, em áreas como clínica médica, pediatria e saúde da mulher, intervenções cirúrgicas de menor complexidade, prevenção de doenças e promoção da saúde. No que concerne aos 
trabalhadores auxiliares de nível elementar e médio, a ênfase recaía, no primeiro caso, nos atendentes, auxiliares de serviços gerais. Sua formação dar-se-ia mediante ações de integração ensino/serviço, de forma descentralizada e recorrendo-se a instrutores e supervisores de nível superior e médio. O contingente de trabalhadores de nível médio seria composto por pessoal tanto previamente habilitado pelo ensino regular e supletivo de segundo grau, quanto pela formação no próprio serviço de trabalhadores com escolaridade mínima de primeiro grau. As áreas de atuação previstas incluíam serviços de enfermagem, saneamento, odontologia e outros serviços finalísticos; serviços de apoio diagnóstico e terapêutico em laboratórios, serviços radiológicos, farmácia, entre outros; e, por fim, serviços de apoio administrativo, documentação e informação em saúde.

Os documentos de referência do Programa definiam como condição básica e essencial os aspectos concernentes à administração de recursos humanos. Previa-se o estabelecimento de planos de cargos e salários no âmbito dos executivos federal e estadual, o que, imaginava-se, tornaria compatíveis as políticas de pessoal das instituições participantes; permitir uma maior movimentação de pessoal entre esferas de governo e instituições; estimular a formação de profissionais nas categorias consideradas mais escassas; estabelecer jornadas de trabalho compatíveis, com ênfase na dedicação exclusiva, e a introdução critérios de ingresso e promoção baseados no mérito e na impessoalidade, entre outras medidas e iniciativas. Neste domínio em particular, vale mencionar, os enunciados do Prev-Saúde tornam pela primeira vez explícitos, e com uma abrangência que se pretendia nacional, uma agenda de gestão do trabalho nas agências públicas de saúde (Prev-Saúde, [1981]).

A perspectiva da sua implementação se mostraria, no entanto, francamente contrária ao aprofundamento da crise global, marcada pela redução geral da atividade econômica, com expressão na capacidade de financiamento do Estado, inclusive do próprio setor previdenciário.

O Prev-Saúde terminaria por se tornar um dentre vários outros planos e programas relegados às prateleiras e, eventualmente, ao esquecimento. Todavia, embora o projeto em seu conjunto tenha sido abandonado, suas principais idéias organizadoras - a um só tempo, de síntese e de formulação original nos marcos do debate sanitário brasileiro - iriam ser retomadas e atualizadas em outros contextos e circunstâncias. No que concerne às questões centrais tratadas aqui, o Programa, ao propor a organização de um sistema de saúde em âmbito nacional, universal e hierarquizado, com foco na atenção básica, confe- 
riu explícita centralidade ao tema dos recursos humanos. Procurou aprofundar a articulação entre a formação de pessoal e a experiência em serviço, assim como aos processos de gestão da força de trabalho. Neste sentido, atualizava e aprofundava a pauta original da Cooperação Técnica, em larga medida contemplada na formulação e implementação do PPREPS desde o seu início e enunciada nos documentos da sua renovação, entre 1978 e 1980 (Opas/Brasil, 1978; 1979; 1980).

No terreno da formação de pessoal de auxiliar, nos níveis elementar e técnico, a expectativa de implementação de um programa que objetivava alcançar a cobertura total da população no que concerne a atenção básica, suscitou a ampliação dos esforços voltados para a formação em massa de pessoal auxiliar. Uma das respostas a estas expectativas foi a implementação do chamado Projeto Larga Escala.

\section{O Projeto larga Escala}

Sob a expectativa de implementação do Prev-Saúde considerou-se fundamental realizar a formação em massa de pessoal de saúde para fazer frente ás metas de expansão da cobertura dos serviços. Com este intuito foi proposto, em 1981, o Programa de Desenvolvimento de Sistemas de Capacitação em Serviço de Pessoal Auxiliar de Saúde, que rapidamente passou a ser referido no setor pela denominação Projeto Larga Escala (PDRHS, 1985a).

De acordo com sua concepção original, o Larga Escala atenderia a uma demanda de duzentos mil profissionais de nível elementar e médio. Todavia, o abandono do Prev-Saúde logo tornou desatualizadas estas ambiciosas metas quantitativas. Como alternativa, o Projeto Larga Escala conferiu centralidade aos aspectos metodológicos e marcou definitivamente a sua opção político-pedagógica pela formação do trabalhador em saúde em oposição às práticas restritas ao mero treinamento utilitário de habilidades.

Conceitualmente, por detrás da noção de 'formação' estava a de desenvolvimento integral das capacidades e potencialidades cognitivas do indivíduo, o estimulo ao aprimoramento de habilidades intelectuais e psicomotoras que não apenas se vinculariam ao exercício profissional. Teriam maior amplitude, se estendendo para a constituição do cidadão e o desenvolvimento da cidadania. Nesse sentido, em acordo com a legislação então vigente, o processo de formação se dividiu em dois componentes: de um lado, a formação 
profissionalizante, coordenada e executada por pessoal de nível superior proveniente das secretarias estaduais; de outro, a educação geral, conduzida pelos departamentos de ensino supletivo das secretarias de educação.

Deste modo, o Larga Escala, sempre sob a liderança determinada da enfermeira Izabel dos Santos, se afastava da perspectiva mais utilitarista da capacitação de recursos humanos que teria guiado a implementação de inúmeros programas verticais de controle de endemias e, posteriormente, mesmo nos programas de extensão da cobertura mais recentes, como o Piass. Nestes, segundo os argumentos críticos, a capacitação era feita em pouco tempo, decorrente do caráter emergencial na implantação dos programas, com currículos voltados para tarefas normatizadas e certificados reconhecidos válidos somente no âmbito restrito da instituição promotora (PDRHS, 1985a: 3-7; 14-26).

Em cada estado da federação previa-se o estabelecimento de um Grupo Estadual de Coordenação com a função básica de coordenar, acompanhar e avaliar as atividades do Programa em âmbito estadual. Cada estado comportaria um determinado número de regiões, como uma forma de estrutura geográfica de organização do programa, e que, regra geral, correspondiam às áreas de atuação das diretorias regionais de saúde. A estratégia compreendia, também, a constituição de uma rede de Centros de Formação de Recursos Humanos. Estes seriam, por definição, unidades reconhecidas pelo sistema educacional, mediante a aprovação de seu documento regimental, teria a função de apoio administrativo e pedagógico requeridos pelo ensino em serviço ministrado e avaliado por instrutores da rede de serviços de saúde. Cada uma destas unidades deveria preferencialmente dispor de biblioteca especializada, além de uma secretaria escolar e um corpo técnico.

Assim, desde a concepção, o Projeto Larga Escala intuiu a necessidade de organização de um espaço que permitisse a validação dos processos de formação. Contudo, esse espaço, devido à especificidade dos alunos como trabalhadores de saúde, deveria romper com as estruturas vigentes. Nessa perspectiva, o conceito de Centro de Formação evolui para o de Escola de Formação Técnica de Saúde, idealizada e concebida a partir do pressuposto de que a escola formal regular existente pouco seria útil para o aluno/trabalhador que, em algum momento de sua vida, tinha sido excluído dessa escola. Portanto, a escola destinada à formação do pessoal de nível médio para os serviços de saúde deveria ter, como princípio primordial, a inclusão; buscar alternativas que incluíssem o trabalhador no processo de formação e o mantivesse até o final do curso; ser flexível e ofertar cursos descentralizados, de forma a atender 
a todos os municípios. Nesse sentido, a escola destinada à formação de pessoal de nível médio para os serviços de saúde deveria ter currículos diferentes dos existentes na escola formal, com instrutores e supervisores de ensino que não se compreendessem como meros transmissores de conhecimentos, e sim como agentes mediadores do ensino e da aprendizagem. Ela se tornaria, nos termos da própria Izabel dos Santos, em vez de uma escola-endereço, uma escolafunção, que se mobiliza para alcançar o aluno-trabalhador em seu próprio ambiente de trabalho e se organiza a partir do trabalho em sua dimensão pedagógica (Castro, Santana \& Nogueira, 2002, p. 60-61).

O desafio metodológico do Projeto Larga Escala exigia, portanto, um desenvolvimento que primasse pela integração ensino e serviço, atendendo a uma necessidade fundamental: proporcionar qualificação específica a uma significativa parcela da força de trabalho inserida nas instituições de saúde, não afastando os trabalhadores de suas atividades. Tratava-se, portanto, de garantir processos educativos vinculados à prática do serviço e que propiciassem ao trabalhador adquirir habilidades e capacidades para pensar e agir. $O$ projeto tinha como propósito possibilitar identidade profissional ao trabalhador por meio da construção sistematizada do conhecimento e de uma abordagem pedagógica crítico-reflexiva. Tỉnha, desta maneira - e sobretudo -, o compromisso com a reorganização dos serviços de saúde, atrelada ao processo de formação de pessoal.

A partir desses princípios, o primeiro passo foi pensar uma proposta pedagógica que atendesse às necessidades do trabalhador do setor Saúde, compreendido como uma pessoa adulta, marginalizada do sistema formal de educação e, no entanto, apta a construir conhecimentos e desenvolver habilidades específicas na formação plena de sua cidadania. Deste modo definia-se a dimensão política do projeto de formação em larga escala, no sentido de “[...] viabilizar a formação para a cidadania plena através de legitimação social de sua prática e sua qualificação específica” (Souza et al., 1991: 33). Nessa perspectiva, alguns pressupostos foram indispensáveis na definição da metodologia a ser desenvolvida para os processos de formação: a indissociabilidade entre o método e o conteúdo; a coerência com a natureza do objeto em construção; e a apropriação da estrutura do conhecimento pelo aprendiz.

Trabalhou-se, portanto, na construção daquelas que viriam a ser algumas das principais aquisições de todo o Projeto: uma metodologia de ensino que enfrentasse o desafio da integração docente-assistencial no âmbito da formação técnica; um currículo que atendesse às necessidades do aluno trabalha- 
dor; uma escola onde o aluno pudesse adquirir o diploma sem abandonar o trabalho; um processo que contemplasse a preparação de pessoal dos serviços para o desempenho das funções de instrutores e supervisores.

O desafio pedagógico seria difícil para instrutores e alunos. Ambos deveriam se libertar dos modelos prescritivos. As reações dos alunos seriam registradas nas palavras de Izabel dos Santos:

Primeiro, os alunos ficaram irritados, diziam que as professoras eram preguiçosas e não ensinavam, e só faziam perguntas. [...]. O começo foi difícil. Teve uma turma no Piauí que se rebelou. Os alunos diziam, 'a gente veio aqui para aprender e não para ficar só respondendo perguntas'. [...] Eu procurava fazer com que eles se encontrassem no processo e percebessem o quanto eles eram importantes. O problema é que eles não acreditavam neles próprios. Eu entendia essa reação. Vejam, as pessoas sempre foram escravas e demitidas da função de pensar, então, qual é o raciocínio do aluno? Que ele vai fazer o curso, que o professor vai ensinar, e que ele vai aprender, não é assim? Ele não consegue imaginar que discutindo se aprende. (Castro; Santana \& Nogueira, 2002: 67-68)

No triênio compreendido entre 1982 e 1984, o Larga Escala foi implementado em quatro estados da federação, segundo uma estratégia que compreendia ações em quatro níveis: (1) criação da infra-estrutura de coordenação, secretaria e biblioteca; (2) capacitação de pessoal de nível superior para o desempenho das atividades de instrução e supervisão; (3) a realização de cursos profissionais propriamente ditos nos níveis médio e elementar, classificados segundo o que era considerado o seu alto ou baixo teor de supletividade frente aos processos regulares e supletivos de ensino; e (4) o desempenho mesmo das ações de supervisão das atividades ${ }^{44}$.

O primeiro estado a ser contemplado foi o Piauí, com os cursos de capacitação de nível superior iniciando-se em março de 1982. Sua clientela foi composta por enfermeiros, em sua maioria (69\%), seguidos de médicos, assistentes sociais e odontólogos, revelando um importante componente multiprofissional. Os próximos estados a se integrarem foram Rio Grande do Norte, em julho de 1982; Alagoas, em setembro do mesmo ano; e, por fim, Minas Gerais, em maio de 1983. Entre 1982 e 1984, no conjunto dos estados,

44 Por alto teor de supletividade entendia-se um maior nível de articulação - quanto a currículos, prazos e necessidades operacionais do serviço - entre o curso ministrado e a formação escolar. O baixo teor de supletividade significava que o curso era desenvolvido de modo mais ou menos autônomos. (PDRHS, 1985b, [Anexo 27]). 
as atividades de formação se concentraram em cursos destinados a visitadores sanitários e classificados pela coordenação do Projeto como de alta articulação com o ensino regular e supletivo, e, portanto, de alta supletividade.

Foram diferenciados os ritmos de desenvolvimento de cada estado no concerne à institucionalização do programa, à constituição dos grupos estaduais e dos centros de formação, secretaria e biblioteca. Neste particular, Rio Grande do Norte e Alagoas foram as unidades da federação mais rapidamente mobilizadas, respectivamente, para a formalização do Grupo de Coordenação Estadual e para instituição do Centro de Formação de Recursos Humanos ${ }^{45}$.

O desenvolvimento do projeto não deixou de enfrentar dificuldades. Em primeiro lugar, uma crítica que objetava quanto a um possível papel formador das instituições prestadoras de serviço de saúde mostrou-se ser sistemática e persistente. $\mathrm{O}$ encontro entre serviço - na perspectiva da saúde - e ensino - na perspectiva do MEC - conformava uma arena, no mínimo, conflituosa. Quanto a este ponto, os responsáveis pela cooperação Opas-Brasil e pela coordenação do Larga Escala retrucavam que o projeto era uma das alternativas possíveis para as dificuldades enfrentadas na introdução da capacitação profissional no ensino regular de segundo grau no país, exatamente pela presença do componente da integração ensino-serviço (PDRHS, 1985a: 7).

Além desta oposição de sentido mais doutrinário, o Projeto enfrentou vicissitudes diretamente relacionadas ao próprio esgotamento dos recursos mobilizáveis para a expansão da rede de serviços básicos, assim como para o suprimento material e humano da rede já instalada, o que - é importante ressaltar - deveria desempenhar um papel fundamental no próprio processo ensino/serviço. Esta restrição afetava particularmente a clientela focal dos primeiros anos do programa, representada pelos atendentes de saúde, envolvidos nas ações junto às populações rurais e pequenas localidades. Dispersos geograficamente, estes trabalhadores tinham seu desempenho mais drasticamente atingido pela situação crítica de funcionamento da rede, pela ausência de vacinas, medicamentos e outros recursos. E o atendente de saúde, transformado em visitador sanitário, deveria ser uma figura chave para os programas de extensão de cobertura.

\footnotetext{
45 Vale indicar ainda que o projeto foi também desenvolvido no então recém instituído estado de Rondônia. Neste caso, porém, o seu desenvolvimento mostrou-se particularmente irregular e na altura de finais de 1984 cogitou-se de encerrar ali as atividades do Projeto (PDRHS, 1985a).
} 
Por outro lado, as tarefas de formulação de currículos e de programação dos cursos ficaram, regra geral, excessivamente concentradas no nível central. A atuação dos membros locais tendia a se restringir a um mero acompanhamento burocrático das atividades, descuidando de todo e qualquer componente pedagógico. A constituição das equipes de supervisores, central na proposta pedagógica, repetia, em certa medida, o conhecido padrão de vulnerabilidade diante das injunções do poder local. $\mathrm{O}$ anseio por reformas e a militância mais engajada se defrontavam com a inércia do conservadorismo.

O Projeto, segundo o enunciado crítico de seus líderes, ressentia-se de uma maior coordenação no âmbito federal. Eram constantes os conflitos de autoridade entre esferas e instâncias, a par de uma reconhecida ambigüidade em torno da própria vinculação funcional do Grupo Assessor Principal, o núcleo executivo da cooperação técnica Opas-Brasil, em relação às autoridades ministeriais. À parte desta ausência de clareza a respeito dos respectivos papéis institucionais, no âmbito da cooperação técnica, havia também uma distribuição de recursos que não refletia as diferentes realidades e complexidades das iniciativas em desenvolvimento em cada estado. O repasse de recursos se operava via conta única das secretarias de educação, o que terminava por dificultar a utilização de recursos pelos projetos locais. Além disso, eram freqüentes os cortes e interrupções no repasse de verbas já garantidas.

As dificuldades com o financiamento do Projeto diziam também respeito à desmontagem do Prev-Saúde. Ao longo de seus primeiros anos, o Projeto Larga Escala foi sustentado principalmente por aportes do Ministério da Saúde e do Ministério da Educação e Cultura. Neste contexto, a ausência do Ministério da Previdência e Assistência Social como um ente apoiador mais efetivo comprometia, de certa maneira, a legitimidade institucional e a própria eficácia de toda a iniciativa. Permanecia, portanto, o desafio da integração entre estas áreas fundamentais na prestação dos cuidados em saúde. Sua resolução seria, em última instância, tarefa de uma nova república.

Em 1981, diante da grave crise de financiamento do sistema previdenciário, instituiu-se o Conselho Consultivo de Administração de Saúde Previdenciária (Conasp). Este conselho fez recomendações expressas no sentido de reorientar a assistência médica previdenciária mediante a celebração de acordos conjunto entre as três pastas ministeriais mais diretamente envolvidas com a prestação de serviços de atenção médica. O Plano Conasp seria, em certa medida, uma base conceitual e política para a formulação do Programa de Ações Integradas de Saúde (Pais), no segundo semestre de 1983, ainda 
como agenda restrita ao âmbito da Previdência. Em maio de 1984, apenas alguns meses depois, as Ações Integradas de Saúde passaram a ser implementadas como principal estratégia setorial, comportando um forte componente de articulação intersetorial, reforço da dimensão pública da saúde, regionalização e hierarquização dos serviços; valorização da atenção básica e desenvolvimento de recursos humanos, entre outros princípios caros ao pensamento reformador em saúde (Brasil. MPAS, 1984; Escorel, 1998: 183-185; Paim, 1986: 167-171).

\section{Novos rumos para Integração Docente- ASSISTENCIAL}

Ao mesmo tempo em que o Projeto Larga Escala era implementado, e também em estreita relação com as expectativas abertas pela formulação e proposição do Prev-Saúde, a Coordenação de Ciências da Saúde, da Secretaria de Ensino Superior do MEC, à época sob a responsabilidade de Frederico Simões Barbosa, lançou o Programa de Integração Docente-Assistencial, o Pida. A Cooperação Técnica Opas-Brasil em RH, na pessoa de José Paranaguá de Santana, compartilhou a redação técnica do documento-base (Coutinho, 2004: 428; Santana, 2006: e.2.;.2.).

Em suas linhas gerais, este programa objetivou amparar o desenvolvimento de projetos de integração docente-assistencial no país. Para isto, o Pida procurou estimular a criação dos chamados Distritos DocenteAssistenciais $(\mathrm{DDA})^{46}$, com o intuito de viabilizar uma maior regionalização e hierarquização da assistência médica e das iniciativas de integração ensinoserviço no setor da saúde. Procurou também estimular, com o apoio de instâncias do MEC, um processo de transformação das bases curriculares dos cursos da área de saúde, de forma a permitir a aproximação do processo de formação de recursos humanos às necessidades dadas pelo avanço da racionalização dos serviços de saúde.

46 Os Distritos Docente-Assistenciais seriam definidos a partir de características gerais como extensão geográfica e funcional, níveis de atenção e aspectos demográficos e socioeconômicos. Cada DDA se transformaria em uma base física e funcional para a realização dos projetos IDA, como também se constituiria como seu lócus administrativo (Sesu/MEC, 1981:23). Em certa medida, um Distrito correspondia a uma Região Docente-Assistencial na terminologia utilizada até então. 
Nesse ponto, cabe salientar que o Programa pretendia promover o desenvolvimento de atividades de pesquisa voltadas para os interesses das comunidades, bem como estimular a criação de estratégias que permitissem uma maior participação dos representantes destas em todo o processo. Tencionava também contemplar todas as categorias profissionais de saúde, em todos os níveis de formação de recursos humanos e prestação de serviços. Todavia, seu tom era marcadamente dirigido às instituições de ensino superior, um dos pontos mais problemáticos do desenvolvimento da Cooperação Técnica em seus anos anteriores.

Esse foco no ensino superior e o protagonismo da Secretaria de Educação Superior (Sesu) na proposição do novo programa IDA sugerem que sobre ela recaiu grande parte das responsabilidades institucionais na direção do programa, como parte, inclusive, de suas competências no que concerne ao ensino universitário das profissões da saúde. Desde finais da década anterior, as iniciativas de IDA recebiam apoio substancial da Fundação Kellogg. Deste modo, é como um dos componentes deste arranjo que a Cooperação Técnica Opas-Brasil compartilhava a condução institucional do programa.

Os responsáveis pela elaboração do documento-base do Programa IDA assinalaram o que seriam, segundo a sua análise, os limites das iniciativas de saúde comunitária em andamento, consideradas tópicas e restritas, e a sua impossibilidade de realizar uma transformação efetiva das práticas docentes no que se refere à uma efetiva integração entre ensino e serviços. Seria preciso promover a sua generalização no ambiente universitário e uma gradativa participação de todas as instituições envolvidas com a atenção em saúde e a assistência médica (secretarias de saúde, Inamps) e com os processos educativos (universidades, secretarias de saúde) na mesma área de execução de cada projeto. (Sesu/MEC, 1981: 15-29).

A coordenação geral seria realizada centralmente por técnicos da Secretaria de Educação Superior (Sesu), do Ministério da Educação, com assessoramento do GAP. A integração e coordenação dos projetos locais seria função de um Grupo de Integração Docente Assistencial (Gida), cuja responsabilidade seria planejar, coordenar, acompanhar e avaliar os programa a serem realizados nos DDAs. O Gida, por seu turno, seria composto por representantes dos serviços de saúde, da previdência social e das universidades. Ainda que o documento do programa não regulamente a participação de representantes da comunidade, estes são também considerados na organização da Gida. 
A apresentação impressa do programa recuperava, ponto a ponto, os princípios que norteavam aquela que deveria ser a expansão da atenção primária à saúde, à luz das diretrizes da saúde internacional tanto no que concerne aos enunciados da Opas a respeito da expansão da cobertura da atenção médica, quanto à Saúde para Todos no Ano 2000, como meta global enunciada pela OMS e à estratégia da atenção primária em saúde. Considerando o movimento de aproximação entre o MS e o MPAS na formulação do Prev-Saúde, dirigia-se principalmente à comunidade universitária da saúde, conclamando-a a uma profunda transformação das práticas dominantes de modo a resgatar aquele que seria uma responsabilidade histórica da universidade. Seria preciso considerar, segundo a Sesu/MEC, uma necessária participação popular no planejamento, condução e avaliação das práticas docentes e de atenção; uma progressiva adoção de uma concepção gradualmente integradora dos currículos, que afirmasse a necessidade de uma formação generalista, orientada por problemas epidemiologicamente relevantes; e que fosse capaz de promover a superação das dicotomias entre ensino básico e clínico, entre teoria e prática; entre ensino e serviço; entre atenção promotora e preventiva e os cuidados curativos; entre o hospital universitário e a rede serviços básicos; e que superasse, deste modo, ainda segundo o documento de lançamento do programa, uma já clássica concepção entre ensino, pesquisa e extensão, como dimensões estanques da missão da universidade (Sesu/ MEC, 1981: 5-11).

Mais do que isso: a Sesu-MEC prospectava que, sob a sua coordenação, com assessoria da Cooperação Técnica Opas-Brasil, um novo e abrangente Programa de Integração Docente-Assistencial fosse capaz de superar aqueles programas comunitários considerados localmente circunscritos e, por isso mesmo, ingênuos em suas pretensões quanto à sua capacidade de transformação do ensino superior em saúde. Desta forma, sob a égide de um Prev-Saúde - que hoje sabemos hipotético - o enunciado programático para a integração docente-assistencial estabelecia a sua inscrição em um movimento de larga envergadura, voltado, em seus próprios termos, para uma completa reformulação do que seriam a conceituação e a prática da atenção à saúde. Movimento de tal abrangência teria, como sabemos, de esperar alguns anos mais.

Entre os últimos anos da década de 1970 e durante a primeira metade da década de 1980, foram vários programas e projetos de integração docente-assistencial desenvolvidos nas universidades brasileiras, em geral, resultantes 
de uma reconfiguração das iniciativas de extensão típicas da medicina comunitária $^{47}$. Sua distribuição regional chegou a alcançar treze estados com sensível concentração, todavia, nas universidades do Sudeste. No conjunto de programas, os cursos mais freqüentemente contemplados foram, pela ordem: medicina, enfermagem, odontologia e serviço social. Era também digna de nota a preponderância de projetos conduzidos nos departamentos de medicina preventiva, secundados, de longe, pelos de pediatria, seguidos pelos de tocoginecologia e psiquiatria/psicologia. A maior parte das experiências, como já mencionado, contou com o apoio financeiro da Fundação Kellogg e não foram poucas as que enfrentaram dificuldades quando este apoio reduziu-se (Feuerwerker \& Marsiglia, 1996: 26).

Em 1982 a Federação Pan-Americana de Faculdades (escolas) de Medicina (Fepafem), a Opas e a Fundação Kellogg estabeleceram em conjunto o Programa de Análise da Integração Docente-Assistencial (Proaida), com alcance continental. A experiência brasileira foi objeto de uma reunião na Faculdade de Saúde Pública da Universidade de São Paulo que, ao fim e ao cabo, terminou por reiterar as dificuldades já registradas pelos projetos diretamente apoiados pela Cooperação Técnica Opas-Brasil em Recursos Humanos. Dentre os problemas identificados, incluíam-se: o conservadorismo da universidade brasileira, a desarticulação estrutural entre as instituições formadoras e as prestadoras de serviço, a freqüente limitação das iniciativas ao mero efeitodemonstração, tornando-as inócuas quanto a sua capacidade de, pela generalização, produzir alteração substantiva das práticas docentes e na qualidade do cuidado médico. Também ficou registrado que de modo mais ou menos regular ocorria um divórcio entre as esferas decisórias do projeto e os níveis de execução direta, o que, no mais das vezes, produzia um cenário de baixa resolutividade. Naquela ocasião, propôs-se que os projetos IDA deveriam superar aquela que seria uma fase preliminar - "empírica" - de sua evolução para atingir maior "base científica", mediante a utilização de critérios populacionais e clínico-epidemiológicos na definição do escopo e metas de trabalho. Igualmente seria o momento de também superar a fase de desenvol-

47 A literatura retrospectiva sobre o desenvolvimento dos projetos IDA no Brasil fornece poucas informações sobre a evolução quantitativa dos projetos ao longo dos anos 1980. Em 1992 eram cinqüenta projetos em desenvolvimento no Brasil (Marsiglia, 1995:62). Além do trabalho de Marsiglia, informações sobre essa trajetória histórica encontra-se em Chaves (1994), Rocha (1985) e Feuerwerker \& Marsiglia (1996). 
vimento de projetos-piloto e atingir a formulação de macro-modelos passíveis de aplicação generalizada (Rocha, 1985:202).

Era ainda presente, em meados da década, uma crítica que pretendia dar conta das dimensões estruturais e determinantes na conformação das práticas de ensino e das suas relações. Nesta linha, em sintonia com os trabalhos de Donnangelo (1976) e Rodriguez Neto (1979), a IDA era percebida ora como mais uma tentativa de imprimir componentes de maior racionalidade a estes processos, ora como uma nova forma de promover atitudes idealistas e voluntaristas, sem, no entanto, em ambas leituras, alterar substantivamente a realidade.

Em 1983, com o intuito de constituir o que seria uma instância de coordenação nacional dos projetos IDA, a Fundação Kellogg e a Capes instituíram o Programa de Apoio Pedagógico aos Profissionais da Saúde (Papps), articulando em formato de rede sete centros regionais e uma coordenadoria geral (Rocha, 1985: 201). A partir de então, a articulação em rede seria, de fato, uma tendência duradoura na forma de organização do conjunto dos projetos IDA no Brasil.

De qualquer modo, os termos e a forma de organização do relatório de 1984, da Cooperação Técnica Opas-Brasil, elaborado em abril de 1985, sugerem que a integração docente-assistencial perdia força como item da agenda programática da própria cooperação. Este quadro, como será visto mais adiante, seria alterado no contexto da Nova República.

\section{COOPERAÇÃO TÉCNICA EM NOVAS BASES}

À medida que chegava ao fim o período de Héctor Acuña como diretor da Opas (1975-1983), o governo brasileiro e, em particular, o Ministro da Saúde Waldyr Arcoverde movimentaram-se no sentido de eleger Carlyle Guerra de Macedo, então coordenador da cooperação Opas-Brasil em RH, como Diretor da Organização Pan-Americana da Saúde. A proposição brasileira terminou vitoriosa, ainda que sofresse a oposição de alguns países latino-americanos e dos Estados Unidos da América. O nome de Guerra de Macedo foi capaz também de superar antigas restrições do Serviço Nacional de Informações. Segundo as suas próprias memórias, o seu perfil, considerado ligado ao desenvolvimentismo mais à esquerda, seria então adequado ao posto e eleitoralmente viável, na avaliação de um Golbery do Couto e Silva, recém-exone- 
rado no cargo de Ministro Chefe do Gabinete, mas ainda muito influente nos círculos palacianos ${ }^{48}$.

Em finais de 1982, o brasileiro foi eleito, superando o peruano David Tejada de Rivero, figura de grande prestígio internacional, tendo sido Ministro da Saúde em seu país, Subdiretor Geral da Organização Mundial de Saúde durante a gestão de Halfdan Mahler e braço direito deste na realização da Conferencia de Atenção Primária de Alma-Ata, em 1978. O médico Roberto Passos Nogueira foi designado, em 1983, coordenador da Cooperação Técnica, em substituição a Carlyle Macedo. Nogueira permaneceria neste posto até o final do ano, quando seria sucedido pelo também médico Cesar Vieira, que então concluía seus estudos de mestrado na Inglaterra. A tarefa de Vieira seria reorganizar a cooperação técnica Opas-Brasil, passando a considerar, além dos recursos humanos, os temas da organização dos serviços e da ciência e tecnologia em saúde, temas estes que gradativamente se tornavam mais presentes na agenda da cooperação.

De fato, paralelamente, a cooperação técnica Opas-Brasil em Recursos Humanos, vivenciava um processo de progressiva ampliação de seus objetos e, em alguma medida, a experiência de elaboração do Prev-Saúde constituiu um ensaio deste movimento. Entre 1982 e 1984, esta tendência se aprofundou, terminando por legitimar-se com adoção, neste último ano, de três componentes programáticos formalmente anunciados nos termos de referência e relatórios produzidos (PDRHS, 1985a). O primeiro componente, sob a denominação de Pessoal de Saúde, dava conta do conjunto de ações tradicionalmente contempladas pela cooperação técnica até então. O segundo e o terceiro componentes organizavam as novas áreas de atuação àquela altura formalizadas, sob as denominações, respectivamente, de Ciência \& Tecnologia em Saúde e Sistemas e Serviços de Saúde.

O componente Pessoal de Saúde, fundamental para os objetivos desta obra, será analisado mais adiante em maior profundidade. Será precedido, todavia, de alguns comentários sobre as novas áreas contempladas na programação, permitindo uma visão de conjunto acerca dos novos marcos organizadores da cooperação técnica nos primeiros dias do governo de José Sarney (1985-1989), que completaria a transição democrática.

\footnotetext{
48 As circunstâncias da eleição de Carlyle Macedo, assim como suas implicações imediatas por certo merecem a atenção dos historiadores. Todavia elas estão além dos objetivos deste trabalho. Para um depoimento pessoal de Carlyle Macedo, ver: Macedo, 2005.
} 
O componente de Ciência e Tecnologia em Saúde vinha sendo desenvolvido de forma incipiente desde 1981 a partir de uma série de atividades de assessoria em torno do tema do planejamento em Ciência \& Tecnologia. Em 1983, uma aproximação com o Conselho Nacional de Pesquisas (CNPq), suscitou a elaboração dos documentos de referência e uma ativa participação do GAP na Reunião Latino-americana sobre Indicadores da Atividade Científica em Saúde, realizada em Washington, sob a coordenação de Juan César Garcia. No ano seguinte, a Opas, com o apoio direto do GAP, definiu uma programação de trabalho para a cooperação técnica no ensino e pesquisa, que envolvia a realização de estudos de situação na América Latina e Caribe. Os trabalhos desenvolvidos no Brasil foram feitos em parceria com o CNPq e apresentados, em novembro de 1984, na I Reunião sobre Cooperação Científica em Saúde na América Latina, realizada em Brasília.

Em sintonia com as propostas decorrentes da reunião, o GAP, a partir de meados dos anos 1980, apoiou a criação de núcleos de tecnologia em saúde no Instituto de Medicina Social, da Universidade do Estado do Rio de Janeiro e na Ensp/Fiocruz e na Universidade Estadual de Campinas (Unicamp). Paralelamente, o GAP liderou a realização de reuniões itinerantes sobre planejamento de C\&T em Saúde no México, Cuba, Colômbia e no próprio Brasil.

A experiência do PDRHS neste domínio não só constituiu uma sensível inovação em termos nacionais na história da cooperação técnica como permitiu a própria OPAS aperfeiçoar, em termos regionais, seus modos de operação em uma área para a qual era conferida uma crescente relevância estratégica.

No âmbito mais interno à Opas-Washington e à Representação no Brasil, o GAP procurou aperfeiçoar mecanismos de coordenação e realizar uma avaliação das performances com levantamento da situação dos centros colaboradores da Organização no Brasil e na América Latina, estabelecer critérios visando a otimização da alocação de bolsas outorgadas pela Opas no Brasil, além de outras medidas (PDRHS,1985a:18-23).

O componente Sistema e Serviços de Saúde também foi formalmente definido em 1984. Contudo, ele teve origem mais remota, pois foi fruto da convergência de duas linhas de trabalho. Uma delas foi referente à atividade de assessoria exercida, desde o final dos anos 1970, pelo grupo técnico em temas relativos à organização do sistema de saúde brasileiro, iniciativa situada fora do escopo imediato do tema de recursos humanos. A própria elaboração do Prev-Saúde, foi uma das ações empreendidas nesta linha de atuação. Simultaneamente aos trabalhos no âmbito do PDRHS, também sob responsabilidade 
da Opas, outras ações tópicas eram desenvolvidas neste domínio, o que representava a possibilidade de atividades superpostas e o risco de redundância. No início de 1985, pretendia-se promover uma maior articulação e consolidar a presença da cooperação em uma área de temática decisiva no momento em que a abertura democrática abria novas perspectivas para o movimento da reforma sanitária brasileira.

Em 1982, a cooperação técnica Opas-Brasil elaborou um denso termo de referência propondo aquele que seria o Programa de Investigação em Serviços de Saúde (Piss). Neste documento, considerando que uma melhor definição de políticas de saúde, em acordo com a realidade social e as carências de organização e racionalidade dos sistemas e serviços de saúde, demandava uma maior base técnico-científica, propunha-se um extenso programa de investigação, com sete áreas temáticas. Entre estas se incluíam: modalidades assistenciais; organização institucional do setor, inclusive seus componentes de financiamento; profissionais de saúde; e pratica médica e políticas sociais (PDRHS, 1985a).

Em 1984, em colaboração com o Ministério da Saúde e o Centro Nacional de Recursos Humanos, do Ipea, a cooperação apoiou a implementação de um programa de investigação em política de saúde, de acordo com os termos de referência do Programa de Investigação sobre Serviços de Saúde (Piss). Nesta linha, o GAP colaborou com o Ministério da Saúde, o CNPq, a Financiadora de Estudos e Projetos (Finep) e a Abrasco em diversas iniciativas de pesquisa relativas ao campo da Saúde Coletiva, permitindo a consolidação de programas de pesquisa no Instituto de Saúde da Secretária Estadual de Saúde de São Paulo e no Núcleo de Estudos Integrados de Saúde da Unicamp, entre outros projetos também articulados às atividades do GAP. Dentre as pesquisa mais abrangentes incluía-se aquela que, desenvolvida em colaboração com a Faculdade de Saúde Pública da Universidade de São Paulo, empreendeu o mapeamento e a elaboração de um perfil dos cerca de quinhentos projetos de investigação em serviços de saúde então em execução.

Esta iniciativa em particular representava mais um esforço no sentido de ampliar a capacidade de coordenação das pesquisas em andamento e de imprimir maior racionalidade aos gastos com financiamento, como parte de uma articulação mais geral das agencias públicas dedicadas ao tema no país. 


\section{O Componente de RH no nOVO CEnÁrio}

Ainda que estes novos componentes representassem desdobramentos importantes da matriz original da cooperação, os temas e ações referentes ao desenvolvimento de recursos humanos em saúde permaneceram como os mais importantes, tanto no que concerne ao tempo de dedicação da equipe central do Programa, quanto ao volume de recursos financeiros envolvidos. $\mathrm{Na}$ altura do início de 1985, e sob o nome genérico de Pessoal de Saúde, o componente reunia sete projetos/atividades distintos: (1) Desenvolvimento de recursos humanos para as Ações Integradas em Saúde; (2) o Projeto Larga Escala, sob a denominação oficial Formação de Pessoal Auxiliar em Serviço; (3) Treinamento em áreas prioritárias; (4) Educação continuada; (5) Educação superior em saúde; (6) Modernização da administração de pessoal e (7) Estudos sobre pessoal de saúde. As atividades referentes ao Projeto Larga Escala, às Ações de Treinamento em Áreas Prioritárias e às atividades de Educação Superior em Saúde eram, em seu conjunto, as mais expressivas, em termos de volume de trabalho.

O Projeto Larga Escala - cujos principais elementos já foram comentados alguns parágrafos atrás - vivia então a expectativa de um processo de dinamização. Este era em boa medida a sua revalidação como estratégia relevante no terreno dos recursos humanos em saúde. De fato, em novembro de 1985, já no percurso do governo Sarney, uma resolução da Comissão Interministerial de Planejamento e Coordenação (Ciplan) definiria o Projeto Larga Escala como estratégia prioritária na preparação de recursos humanos no âmbito das Ações Integradas de Saúde, ao mesmo tempo em que ratificava a participação do ministérios da Saúde e Educação, das secretarias estaduais de saúde, de educação e da Opas no desenvolvimento e consolidação do projeto, assim como incorporava o Ministério da Previdência e Assistência Social, através do Instituto de Assistência Médica da Previdência Social, ao sistema de formação proposto pelo projeto (Ciplan, 1985).

Valendo-se da metodologia desenvolvida pelo Projeto Larga Escala e do seu componente de integração entre ensino e serviço, coube à equipe da cooperação técnica do GAP desenvolver programas de capacitação de pessoal em áreas consideradas prioritárias pelo Ministério da Saúde. Desta forma, a atividade de Treinamento em Áreas Prioritárias incluiu, no âmbito do Programa de Atenção Integral à Saúde da Mulher e da Criança (Paimsc), a realização de 
ações de treinamento para médicos, enfermeiros, técnicos de laboratório e atendentes, categorias profissionais consideradas fundamentais para o desenvolvimento do programa.

A atividade orientada para a Educaşão Superior em Saúde esteve, na altura da metade da década de 1980, concentrada no apoio aos cursos de graduação de enfermagem e medicina. No ensino de enfermagem, a cooperação técnica atuou como referencia para os processos de desenvolvimento curricular e de tecnologias educacionais. A principal clientela institucional permanecia localizada nas universidades do Nordeste, entre as quais as do Maranhão, da Bahia, e do Sergipe. Porém, a cooperação também atendeu às instituições do sudeste, entre estas a Universidade Federal de Minas Gerais, a Universidade de São Paulo, tanto na capital do estado quanto em Ribeirão Preto, e a Universidade Estadual de Campinas. Também quanto ao ensino de enfermagem o GAP assessorou a elaboração de um programa de cooperação horizontal entre a Universidade de São Paulo e a Universidade Federal do Rio Grande do Sul.

A Cooperação Opas-Brasil em RH, com o apoio da Universidade Federal de Uberlândia, em relação às tarefas de processamento eletrônico de dados, empreendeu a realização de um cadastro nacional de escolas médicas. Os dados coletados e sistematizados foram objeto de uma série de seminários regionais ao longo de 1984 com vistas à publicação de uma síntese analítica pelo GAP, em colaboração com a Secretaria de Ensino Superior, do Ministério da Educação e Cultura (Santana, 2006: e.2; f.3).

Coube também à Cooperação Técnica realizar a uma avaliação programática e de operação no Brasil do Programa Ampliado de LivrosTexto (Paltex), destinando a publicação subsidiada de obras didáticas para o ensino superior das profissões de saúde. Propôs-se uma descentralização da gestão do programa, uma solução que sofreu restrições de várias ordens por parte da Fundação Pan-Americana da Saúde e Educação (Pahef), a sua gestora em toda a região das Américas. Como solução intermediária, a partir de 1984, a Fundação de Amparo ao Estudante passou a responsabilizar-se pelos seus aspectos operacionais no Brasil, ficando o GAP encarregado da orientação técnica e programática. Nos anos seguintes esta orientação passaria a contemplar a seleção, preparação e publicação de materiais instrucionais para a capacitação de nível médio em saúde (Santana, 2006: e.2, f.3).

Quanto aos investimentos em Educação Continuada, procurou-se inicialmente articular ações de capacitação em serviço em andamento nas secretarias estaduais e municipais no intuito de se constituir um projeto de características 
globais a ser apoiado pela Opas e pela Cooperação. Reuniões realizadas com este propósito revelaram a inviabilidade da proposta, tendo em vista as diferentes concepções e alternativas metodológicas adotadas nas diferentes regiões do país. Assim, optou-se por realizar algumas atividades isoladas com a Secretaria Estadual de Saúde do Piauí e de Minas Gerais, com o Nutes/UFRJ e outros órgãos.

Gradativamente o componente da gestão do trabalho em saúde se tornaria mais relevante na construção da pauta da Cooperação Técnica. Com regularidade sua equipe era convocada a apoiar a secretarias estaduais e municipais de saúde para a elaboração, implantação e revisão de planos de cargos e salários, ainda que a crise fiscal generalizada, tenha restringido as possibilidades de uma abordagem integral das questões neste domínio. Nesta direção, o GAP colaborou com as secretarias estaduais do Piauí, Minas Gerais, Rio de Janeiro, São Paulo, Paraná e Santa Catarina, e, ainda, com a secretaria do município do Rio de Janeiro. Da mesma forma, a Cooperação Técnica era acionada para apoiar o desenvolvimento institucional dos órgãos de recursos humanos nos estados e municípios.

Em 1984, em uma linha de trabalho que dois anos mais tarde se tornaria central para a cooperação, foi conferida prioridade para a capacitação nas funções de gerência e desenvolvimento de recursos humanos. O GAP promoveu a realização de um Curso de Especialização em Desenvolvimento de Recursos Humanos, tendo assumido para tanto as responsabilidades de planejamento, execução e suporte financeiro da iniciativa (PDRHS, 1985a: 1-15).

Em meados da década de 1980, a equipe do Acordo de Cooperação Técnica havia também se expandido. Em parte como conseqüência da própria ampliação de seus temas e áreas de atuação; de outra parte como fruto de um processo de re-ordenamento interno à própria Opas e da sua representação no Brasil.

Cesar Viera, coordenador da Cooperação, compartilhava com Danilo Garcia, Francisco Salazar e Propício Caldas Filho o componente de Sistemas e Serviços de Saúde. O ingresso de Alberto Pellegrini, em 1980, com experiência anterior voltada para temáticas ligadas à organização de sistemas de saúde e à ciência \& tecnologia, possibilitaria um contínuo e firme desenvolvimento do novo componente de Ciência e Tecnologia. Em 1984 ele era apoiado por Antonio Briquet de Lemos, indicado pelo Ministério da Saúde.

No componente Pessoal de Saúde, Izabel dos Santos, José Paranaguá, Roberto Nogueira e Francisco Lopes, membros veteranos, eram, em 1985, 
secundados por Ena Galvão, Glória Briceño, Thereza Grandi e Suzana Alayo e formavam a equipe mais numerosa.

No contexto da expansão dos temas e atividades da Cooperação e da implantação das AIS como estratégia central do setor saúde - que inclusive permitia, segundo análises da época, um maior espaço de atuação políticoinstitucional por parte do movimento reformador da saúde - a equipe do GAP sugeriu a extinção da Comissão de Coordenação, a instância de orientação e articulação da Cooperação Opas-Brasi ${ }^{49}$. Propunha-se que esta função de coordenação estratégica passasse a ser exercida pela Ciplan, que desde 1980 caracterizava-se como sendo a primeira instância de planejamento conjunto à área da saúde pública e com a medicina previdenciária.

Àquela altura, a proposta defendida pelos membros do GAP procurava ajustar as funções de coordenação à nova amplitude assumida pela Cooperação, uma vez que esta já se ocupava de temas que transcendiam aos estritos limites das questões de desenvolvimento de recursos humanos. A Ciplan fora desenhada para funcionar como instância estratégica de articulação em alto nível decisório, sendo composta pelos secretários gerais e pelas secretarias técnicas de cada pasta. Por meio da Portaria Interministerial n ${ }^{\circ} 3$, de abril de 1984, o Ministério da Educação e Cultura passou também a compor o conjunto de pastas ministeriais com assento na Ciplan. Deste modo, esta passava representar exatamente o tipo de arranjo institucional pretendido pelo GAP para a condução de uma cooperação que agora se voltava para uma abordagem integrada de temas referentes à organização dos serviços, ao desenvolvimento científico e tecnológico, assim como dos recursos humanos. (PDRHS, 1995a: 47-48).

Em certa medida, a definição da Ciplan como ente responsável pela orientação institucional das atividades do PDRHS implicava também, aos olhos do GAP, aprofundar o que seria um necessário processo de nacionalização das atividades tipicamente de governo então sob a responsabilidade da equipe da Cooperação Técnica Opas-Brasil.

Em 1985, o $9^{\circ}$ Termo Aditivo ao Acordo para um Programa Geral de Recursos Humanos para a Saúde no Brasil, firmado pelos ministros Carlos Sant'anna, da Saúde, Marco Maciel, da Educação, Waldir Pires, da Previdência e Assistência Social, Renato Archer, da recém-criada pasta da Ciência e Tecnologia, e por

49 Para o contexto e os debates em torno da implantação das Ações Integradas de Saúde, ver Paim, 1986: $167-171$. 
Florentino Garcia Scarponi, representando a Opas, iria dar tintas formais ao processo de expansão dos âmbitos de atuação e da base institucional da Cooperação Técnica.

Nesse instrumento, com vigência estipulada até dezembro de 1988, não só o novo Ministério da Ciência e Tecnologia foi incorporado ao programa de cooperação, como os objetos desta última passaram a ser expressamente definidos como orientados à expansão e à melhoria da infra-estrutura dos serviços de saúde e ao aperfeiçoamento dos meios de coordenação entre instituições e atividades nesta área. Por infra-estrutura de serviços de saúde considerava-se as atividades de planejamento e organização de sistemas e serviços de saúde; o desenvolvimento de recursos humanos e, por fim, pesquisa científica e tecnologia em saúde. O mesmo instrumento, confirmou a expectativa da equipe do GAP em transferir à Ciplan as atribuições de coordenação, que antes eram da alçada da Comissão de Coordenação. Este mesmo instrumento atribuiria uma nova denominação para a cooperação técnica: Cooperação para o Desenvolvimento da Infra-estrutura de Serviços de Saúde no Brasil. 


\section{O Legado dos Pioneiros}

No contexto da Nova República, da mobilização em torno da realização da VIII Conferência Nacional de Saúde e do funcionamento do Congresso Nacional Constituinte, da implementação das Ações Integradas de Saúde (AIS) e dos Sistemas Unificados e Descentralizados de Saúde (Suds), a ampliação da agenda da cooperação e a complexificação das suas parcerias institucionais terminariam por impor uma paulatina dissolução do seu núcleo técnico original.

De fato, em 1985, refletindo essa expansão de temas, objetos, e ações, o Programa sofreu um novo processo de institucionalização, já sob a égide da Nova República e dos anos terminais do regime autoritário. O Ministério da Ciência e Tecnologia passou a integrar o elenco de pastas ministeriais participantes da cooperação e esta passou a incluir, entre os seus objetivos formais, além do desenvolvimento de recursos humanos, o aperfeiçoamento da infraestrutura de serviços de saúde e das políticas e programas de pesquisa científica e tecnológica em saúde, com uma correspondente alteração do peso relativo dos recursos disponibilizados para cada item programático.

Nos anos seguintes, a cooperação, a sua agenda e os seus personagens se viram imersos em momentos decisivos na reforma sanitária brasileira, na realização da VIII Conferência Nacional de Saúde e na proposição de um sistema de saúde único e universal. A conjuntura registra a dispersão da boa parte do seu grupo pioneiro em direção a novos postos na Opas e no Instituto de Assistência Médica da Previdência Social (Inamps). A própria denominação Grupo Assessor Principal tornava-se cada mais rara nos próprios documentos da cooperação. Em 1987, ela seria oficialmente abandonada. 
Descrevem-se, neste capítulo, essas alterações vivenciadas pela Cooperação Técnica, assim como os seus desdobramentos. Mantida a ênfase nos temas dos recursos humanos, serão especialmente discutidas a realização da Conferencia Nacional de Recursos Humanos e das políticas nesta área implementadas pelo Inamps, iniciadas na gestão de Hésio Cordeiro como presidente do instituto.

O capítulo se encerra com a discussão daqueles que seriam os principais legados da cooperação.

\section{Recursos humanos rumo à Reforma Sanitária}

Em 1985 começa a diáspora. Neste ano, Cesar Vieira deixou a Coordenação do GAP, sendo substituído por Roberto Passos Nogueira, já integrante da equipe e que ocuparia o posto até o ano seguinte, quando foi substituído pelo odontólogo mineiro Eugênio Vilaça Mendes. O destino de Vieira seria, na sede da Opas em Washington, as áreas de planejamento e avaliação da cooperação técnica da organização para a América Latina. No ano seguinte, Roberto Passos Nogueira e Alberto Pellegrini Filho também passariam a ocupar postos na sede em Washington, dedicando-se, respectivamente, à pesquisa em recursos humanos e à gestão de ciência e tecnologia, agora em âmbito continental. Danilo Garcia passou gradativamente a se ocupar de missões institucionais da Opas junto aos governos latino-americanos, entre estes os da Argentina, da Bolívia e do Uruguai. Os demais veteranos - entre estes e de forma especial Francisco Lopes, José Paranaguá Santana e Izabel dos Santos - manteriam as conexões mais diretas com o desenvolvimento de recursos humanos em saúde e com as iniciativas institucionais brasileiras neste domínio. Paranaguá, no entanto, iria fazêlo a partir de um novo posto, junto à nova presidência do Inamps.

Em maio de 1985, a convite de Hésio Cordeiro, então recém-empossado como presidente do Instituto de Assistência Médica da Previdência Social (Inamps), José Paranaguá de Santana assumiu a cargo de diretor de Modernização Administrativa e Desenvolvimento de Recursos Humanos naquele instituto. A primeira tarefa de Paranaguá de Santana foi estabelecer um Departamento de Recursos Humanos, como parte da estrutura permanente do instituto. Esta missão, inicialmente tópica e com duração prevista para alguns meses, terminou por se desdobrar em um vínculo mais permanente, alongandose até maio de 1988. 
Em meados da década, o Inamps havia se constituído em verdadeiro baluarte do movimento da reforma sanitária brasileira. A implantação das Ações Integradas de Saúde, mediante a celebração de convênios com estados e municípios, recebeu um vigoroso impulso ${ }^{50}$. Da mesma forma, realizou-se uma reversão da histórica tendência de orçamentos declinantes para o financiamento da assistência médica previdenciária, o que possibilitou, entre outras iniciativas, a recuperação da rede hospitalar própria. E ao propor a implantação do Suds, como parte do esforço para prestação de um atendimento médico universal e integral, e que contemplava a descentralização político-administrativa e a participação social na gerência dos sistemas e serviços de saúde, o Inamps, àquela altura, reafirmava e produzia conseqüências práticas para vários dos princípios caros ao movimento.

O período da gestão Hésio Cordeiro correspondeu também àquele da ampla mobilização para a realização, em Brasília, em março de 1986, a VIII Conferência Nacional de Saúde. Este evento teve como, objetivos centrais, a discussão da reorganização do Sistema Nacional de Saúde e, sobretudo, criar condições que permitissem, com significativo êxito a institucionalização dos princípios fundamentais da reforma, naquele que seria o texto constitucional de 1988.

A Cooperação Técnica e, individualmente, vários dos componentes da sua equipe tiveram papel ativo nos bastidores desta Conferência. Da mesma forma, a presidência e diretorias dos Inamps constituíram-se em uma das bases políticas e institucionais mobilizadas para a sua realização.

Os aspectos gerais do Relatório Final da VIII Conferência Nacional de Saúde são bem conhecidos e discutidos ${ }^{51}$. No domínio dos recursos humanos, o relatório identifica como causas das precárias condições dos serviços de atenção à saúde: aquela que seria uma inadequada formação dos recursos humanos, tanto no que concerne aos seus conteúdos técnicos quanto "aos seus aspectos éticos e de consciência social"; e, no plano mais estrito de uma administração de RH, utilização do pessoal de saúde sob condições consideradas insatisfatórias de remuneração e trabalho e a sua contratação baseada em práticas clientelistas (Brasil. VIII CNS, 1986: 6-7).

Dado este diagnóstico, o Relatório Final propôs princípios orientadores para a gestão e desenvolvimento de recursos humanos em saúde, no âmbito

50 Entre 1985 e 1988, as AIS passaram de 112 para 2.800 municípios envolvidos (Buss, 1988: 346).

51 Para a história da VIII Conferência e do Sistema Único de Saúde, ver Lima et al., 2005. Para o texto completo do Relatório, ver http://chagas.redefiocruz.fiocruz.br/ ensp/biblioteca/dados/ 8 conferencia.pdf. 
de seu tema n. 2, dedicado aos princípios gerais de organização do Sistema Único de Saúde. Assim, estabelecia-se que deveriam ser perseguidos: (1) uma remuneração condigna e isonômica; (2) uma formação integrada ao sistema de saúde, assim como a capacitação permanente de pessoal; (3) a realização de concurso público como meio de ingresso e a estabilidade no emprego e a dedicação exclusiva como regimes preferenciais; (4) a composição multiprofissional das equipes de saúde, considerando o quadro epidemiológico das regiões e os padrões mínimos de cobertura a serem atingidos; (5) o exercício do direito de greve e de sindicalização; (6) a inclusão nos conteúdos dos processos de formação e capacitação das denominadas práticas terapêuticas alternativas; e, ainda, (7) a incorporação dos agentes populares de saúde como categorial formal e remunerada de trabalhadores, principalmente para a realização de atividades de educação para a saúde e cuidados primários (Brasil. VIII CNS, 1986: 11-12).

Além de estabelecer estas orientações, a VIII Conferência recomendou a continuidade do processo de debate e a realização de processos complementares para a discussão em maior detalhe e formulação de políticas para os temas específicos. Assim, em outubro de 1986, também em Brasília e escassos sete meses depois da Conferência Nacional, realizou-se a Conferência Nacional de Recursos Humanos para a Saúde, sob o tema "Política de Recursos Humanos rumo à Reforma Sanitária" ${ }^{32}$.

Promovido pelas pastas da Saúde, da Educação, da Previdência e Assistência Social e pela Opas, o evento foi coordenado, por delegação da Ciplan, por uma comissão constituída por Ana Rosa Bogliolo e Maria Regina Vergueiro, indicadas pelo MEC; Izabel dos Santos e Roberto Passos, pela Opas; José Paranaguá, pelo Inamps/MPAS; Paulo Buss, pela Ensp/Fiocruz; e Tânia Celeste Nunes, pelo Ministério da Saúde. A organização da conferência coube a uma comissão presidida por Tânia Nunes, à época ocupando o posto de secretária de Recursos Humanos no ministério.

Cinco grandes eixos balizaram as discussões, segundo seu Relatório final, a saber: (1) a valorização do profissional de saúde, (2) preparação de Recursos Humanos, (3) as estratégias de integração interinstitucional para os órgãos de desenvolvimento de recursos humanos; (4) a organização dos trabalhadores e

52 O relatório final da conferência encontra-se em Brasil. Ministério da Saúde, 1986. Uma coletânea de trabalhos apresentados à conferência foi publicada pelos Cadernos de Saúde Pública. Para o editorial deste número ver Nunes, 1986. Para uma análise da Conferência Nacional de Recursos Humanos no âmbito dos recursos humanos como tema das conferências nacionais de Saúde, ver Sayd, Vieira Junior \& Velandia, 1998. 
(5) a relação do trabalhador de saúde com o usuário do sistema. No primeiro tema, valorização profissional, os participantes trataram de aspectos relativos ao mercado de trabalho, ao recrutamento e ao processo de seleção do pessoal de saúde, estágios, jornadas e regimes de trabalho, planos de cargos e salários, avaliação de desempenho profissional, lotação e remanejamento de pessoal, assim como da relação entre a equipe de saúde e a gerência dos serviços. Como elemento comum, articulando estas várias dimensões, a preocupação com a constituição de uma força de trabalho pública em saúde renovada.

No segundo eixo, relativo à preparação de recursos humanos, foram incluídos os seguinte itens: a formação e aprimoramento nos níveis médio e elementar; o ensino de graduação das profissões de saúde; a educação continuada em todos os níveis; o ensino de pós-graduação; e a integração docenteassistencial.

Quanto às estratégias de integração interinstitucional dos órgãos de desenvolvimento de recursos humanos, o terceiro eixo organizador da conferência, considerava-se que os mesmos sofriam de uma persistente desarticulação e que as áreas de RH, historicamente, se situavam de forma marginal nos processos decisórios da gestão dos serviços de saúde. Embora esta posição secundária seja apontada como um problema relativo à organização do sistema como um todo, considerava-se, também, que, em larga medida, decorria da ausência de uma formação profissional adequada dos próprios profissionais de RH. Esta lacuna, por seu turno, implicava uma não percepção do próprio papel dos recursos humanos no processo de reforma do sistema de saúde.

A conferência revela o aumento da importância relativa dos temas mais diretamente concernentes à gestão do trabalho, como dimensão específica e que, em certo sentido, tenderia a ganhar maior autonomia no contexto do desenvolvimento dos recursos humanos. De todo modo, os três primeiros eixos, em seu conjunto, sem dúvida revisitaram e atualizaram os tópicos constitutivos da historia recente do desenvolvimento de recursos humanos em saúde, tal como vivenciada pela experiência da Cooperação Técnica Opas-Brasil.

O contexto da redemocratização, porém, permitia a inclusão na agenda de novos itens especialmente orientados para a organização dos trabalhadores e, por esta via, para o adensamento da sua atuação como atores do processo de reforma. E, mais importante, o controle social, como componente da gestão do sistema único de saúde, introduzia a relação entre o profissional de saúde e o usuário do serviço como um novo tema de recursos humanos. 
Assim, no eixo quatro, a conferência tratou da organização dos trabalhadores em saúde. Entre os temas discutidos: os direitos trabalhistas dos servidores públicos; isonomia salarial e condições de trabalho. O eixo cinco, por seu turno, considerou as relações entre trabalhadores e usuários sob a lógica da co-responsabilidade dos atores coletivos representados pelas categorias de Estado e Instituições, Trabalhadores, e, por fim, Usuários.

Sob a perspectiva do desenvolvimento histórico da Cooperação Técnica Opas-Brasil em Recursos Humanos, vale a pena observar as recomendações presentes no Relatório da Conferência Nacional de Recursos Humanos para Saúde, naquilo em que estas se articulam aos temas centrais da cooperação desde a gênese e anos iniciais do Ppreps, em 1976.

\section{UMA AGENDA DE RH PARA A REFORMA POSSÍVEL}

Simultaneamente às discussões da VIII CNS e da Conferência Nacional de Recursos Humanos para a Saúde, implantava-se, sob a liderança do Inamps, o Sistema Unificado e Descentralizado de Saúde (Suds), estratégia de consolidação das Ações Integradas em Saúde. A criação do Suds espelhou um importante grau de institucionalização das propostas que caracterizariam, poucos anos depois, o Sistema Único de Saúde, os princípios da universalização e da eqüidade do acesso aos serviços de saúde; a integralidade dos cuidados; a assistência regionalizada, segundo o funcionamento de diferentes distritos de saúde; a criação de instituições colegiadas gestoras e o desenvolvimento de uma política de recursos humanos que atendesse as necessidades do sistema já faziam parte das suas estratégias e dos seus objetivos programáticos.

Nesse contexto - e nesse sentido -, a política de recursos humanos implementada pelo Instituto informava e refletia os debates e proposições das instâncias que organizavam e explicitavam a pauta do movimento da reforma sanitária.

Esta política consistiu na reformulação organizacional e implantação do sistema de desenvolvimento de recursos humanos do Instituto e, ao mesmo tempo, na implantação de um processo de descentralização administrativa, atinente aos RH, o que envolvia, inclusive, os recursos orçamentários para dinamização das atividades de capacitação de pessoal de saúde. Tal reformulação significou, na prática, a criação do Departamento de Desenvolvimento de Recursos Humanos e Modernização Administrativa, tanto no âmbito da Direção Geral, quanto das Coordenadorias e Superintendências 
Regionais; a definição de uma estrutura que se pretendia mais racional e funcionalmente mais ágil para as unidades operacionais do sistema de DRH; e, finalmente, a criação dos Centros Formadores de Pessoal de Nível Médio (Santana, 1986).

Àquela altura, o Inamps e os demais órgãos envolvidos na Cooperação Técnica operavam de modo a promover a criação e fortalecimento, nas instituições de ensino e pesquisa, de núcleos de competência no terreno da saúde coletiva, como massa crítica para suporte técnico-científico da própria reforma sanitária em andamento, um processo que, vale dizer, remontava à própria realização dos cursos descentralizados de saúde pública, iniciada em 1975. Instalados geralmente nas universidades, como forma de vínculo menos sujeita aos humores da política estadual, estes núcleos de saúde coletiva funcionaram também como espaços institucionais por meio dos quais atuavam e interagiam, entre outros personagens, os egressos dos cursos descentralizados de saúde pública, representantes regionais e sócios do Cebes e da Abrasco, participantes e coordenadores dos projetos de integração docente-assistencial, profissionais e gestores de recursos humanos em saúde nos estados e municípios (Santana, 2006: e.2, f.3).

Esses núcleos, que compartilhavam siglas como Nesc, Nescon, Nesp eram também elos de ligação que ajudavam a conformar a rede social evolvida no movimento de reforma da saúde nos estados. E como tais, ao lado das Escolas de Saúde Pública, constituíram as bases acadêmicas a serem mobilizadas para a formulação e implementação de políticas e programas também no âmbito dos recursos humanos em saúde. Foram também fundamentais quando se tratou de viabilizar qualquer processo de descentralização neste domínio, tanto no que concerne à gestão, como ao preparo de pessoal de saúde (Santana, 2005: e.1, f.3; e 2006: e.2, f3).

Tratava-se, entretanto, vale registrar, de uma via de mão dupla: em boa medida as atividades de pesquisa e ensino no terreno dos RH em saúde foram também meios decisivos para a própria consolidação destes núcleos. Como examinado no capítulo 3, a Cooperação Técnica Opas-Brasil desempenhou um papel importante na constituição dos núcleos de desenvolvimento de recursos humanos junto às secretarias estaduais de saúde e, dessa maneira, promoveu a constituição deste campo na sua dimensão gerencial e operacional. Por meio dos núcleos de ensino e pesquisa dedicados à saúde coletiva foi possível exercer influência similar na configuração da face acadêmica deste mesmo campo. Deste modo, também neste domínio, a reforma da saúde em 
seu andamento, as suas novas bases institucionais, se retro-alimentavam na produção de novas e maiores condições para conhecer e agir.

O desenvolvimento das AIS e da sua estratégia de implantação a partir dos Suds constituíam uma demanda consistente por pessoal de saúde qualificado, em especial de nível elementar e médio, e isto era válido tanto para o pessoal já incorporado às atividades de atenção, quanto para a formação de novos quadros. A estratégia adotada para fazer frente a esta expectativa de demanda seria articular a constituição de uma rede renovada e ampliada de centros formadores de pessoal e a adoção do Larga Escala como projeto e metodologia central na formação e capacitação orientadas pela integração entre ensino e serviço (Brasil. Ciplan, 1985).

Paralelamente, conformava-se um cenário que parecia ser especialmente promissor para o desenvolvimento dos projetos de IDA. A presença de José Paranaguá de Santana no Departamento de Desenvolvimento de Recursos Humanos e Modernização Administrativa do Inamps; de Francisco Campos - personagem historicamente associado ao movimento de medicina comunitária e de implantação do internato rural na UFMG -, então na Secretaria de Recursos Humanos do MS; e de João José Cândido da Silva, na Coordenação de Ciências da Saúde do MEC, permitiria a montagem de um renovado arranjo institucional em sustentação às diretrizes estabelecidas no Programa de Integração Docente Assistencial (Pida), de quatro anos antes. Esta iniciativa recebeu, a princípio, o apoio político de Carlos Santana, Jorge Bornhausen, Waldir Pires e Hésio Cordeiro, titulares, respectivamente, das pastas da Saúde, Educação e Cultura, da Previdência e Assistência Social, e do Inamps. Uma minuta de portaria interministerial e de um programa anexo que reiterava os termos do documento elaborado em 1981 chegou a ser assinada pelos ministros (Santana, 2006: e.2, f.2).

Sua publicação, porém, não se efetivaria. A Associação Brasileira de Escolas Médicas (Abem), então sob a presidência de Clementino Fraga Filho e a direção executiva de Alice Rosa, manifestou o seu desacordo com a proposta. Segundo algumas avaliações, a Abem, então representada por Clementino Fraga Filho e Alice Rosa considerava que o Programa IDA, tal como formulado, punha em xeque a autonomia universitária, implicando em riscos à uma pauta de pesquisa eventualmente menos alinhada às estritas necessidades do serviço. Segundo esta interpretação, a Rede IDA, criada no mesmo período, pretendeu superar estas dificuldades em âmbito institucional, mediante a mobilização e articulação política das lideranças dos projetos em andamento (Santana, 2006: e.2, f.2). 
O encaminhamento de um processo de reforma, especialmente de descentralização político-administrativa, na área específica de recursos humanos, esbarrava na capacidade de mobilizar servidores de cerca de 120 unidades técnico-administrativas do Instituto, situadas junto à direção geral e distribuídas pelas superintendências regionais. Nesse contexto, o pessoal das unidades da ponta do sistema deveria ser estrategicamente qualificado, num processo dinâmico e contínuo, capaz de orientá-lo a desenvolver, em condições de relativa autonomia, maior capacidade de gerência local. A estratégia que seria adotada para fazer frente a esta carência comportaria a concepção e realização de uma serie de cursos especialmente dirigidos para a capacitação dos profissionais envolvidos nos processos de gestão em RH. Em 1987, tem início, com o aporte do pessoal técnico da equipe da Cooperação Técnica do Acordo Opas-Brasil, o Curso de Aperfeiçoamento em Desenvolvimento de Recursos Humanos, o Cadrhu.

O Instituto Nacional da Previdência Social mantinha então em sua estrutura, como parte do seu papel tradicional na formação de pessoal de saúde, seis escolas de auxiliares de enfermagem, vinculadas às superintendências regionais nos estados do Maranhão, Pernambuco, Bahia, Goiás, Rio de Janeiro e São Paulo. É este conjunto inicial de estabelecimentos de ensino que constituirá as bases de uma renovada e ampliada rede de centros formadores de recursos humanos. Esta rede pré-existente e a experiência do projeto Larga Escala na constituição de centros de formação de recursos humanos, iniciada em 1982, seriam, nos anos seguintes, as bases para um movimento de constituição de um conjunto de centros e escolas que rapidamente superariam a marca de vinte estabelecimentos mais ou menos integrados ${ }^{53}$. Este movimento, todavia, já transcendia de muito o âmbito institucional imediato do Inamps. De fato,

53 Em 1990, eram 25 centros formadores e escolas técnicas integradas ao então recentemente instituído Sistema Único de Saúde, SUS. Eram elas: Centro Formador de Recursos Humanos para a Saúde Dr. Waldir Arcoverde (AL); Escola de Formação Técnica em Saúde Professor Jorge Novis (BA); Escola de Saúde Pública (CE); Centro Formador de Recursos Humanos para a Saúde (PB); Escola de Saúde Pública (PE); Centro de Formação de Pessoal para os Serviços de Saúde Dr. Manuel da Costa Souza (RN); Centro de Formação em Saúde Coletiva (ES); Centro Formador de Recursos Humanos para a Saúde/Escola de Saúde de Minas Gerais - FED (MG); Escola de Qualificação Profissional da Fundação Hospitalar de Minas Gerais (MG); Escola Técnica de Saúde da Universidade Estadual de Montes Claros (MG); Escola de Formação Técnica em Saúde Enfermeira Izabel dos Santos (RJ); Escola Politécnica de Saúde Joaquim Venâncio (RJ); Centro Formador de Osasco (SP); Centro Formador de Araraquara (SP); Centro Formador de Franco da Rocha (SP); Centro Formador de Assis (SP); Centro Formador de Vila Mariana (SP); Centro Formador de Pariquera-açu (SP); Centro Formador de São Paulo SES-SP (SP); Centro Formador de Recursos Humanos para a Saúde Caetano Munhoz da Rocha (PR); Escola de Formação em Saúde (SC); Escola Técnica de Saúde de Blumenau (SC); Centro Formador de Pessoal de Nível Médio para a Área da Saúde (GO); Escola Técnica de Saúde (MT); Centro Formador de Recursos Humanos para a Saúde (MS). (Sório, 2002: 6). 
nesta nova configuração, as escolas e centros estariam vinculados às várias esferas de governo, com nítida predominância do nível estadual e do vínculo direto às secretarias estaduais de saúde. Tratava-se assim, neste sentido, de um movimento em ampla medida bem sucedido de descentralização que, tal qual o estabelecido no desenvolvimento do Projeto Larga Escala, se deu de modo orientado para a esfera estadual de governo (Sório, 2002: 7).

Como parte deste processo, o Inamps assumiu a diretriz de se integrar efetivamente aos projetos em andamento no âmbito do Larga Escala e que correspondiam aos estados do Piauí, Rio Grande do Norte, Alagoas e Minas Gerais. A expectativa na altura de finais de 1986 era de que, com o apoio direto do Inamps, o Larga Escala pudesse ser levado a mais dez estados, na condição de estratégia central do instituto para a formação em serviço dos seus profissionais. A própria expansão da rede de escolas técnicas revelaria o fôlego desta pretensão.

Como sinalizado anteriormente, a constituição de um sistema de gestão e desenvolvimento de recursos humanos, que operasse de forma descentralizada, exigiria um esforço de qualificação profissional daqueles a serem institucionalmente responsáveis por estas tarefas em âmbito estadual ou municipal. Tratava-se também de aprofundar a estratégia de constituição de núcleos estaduais de recursos humanos, cuja origem remonta à formulação original e os primeiros momentos de implantação do Ppreps.

O Curso de Aperfeiçoamento em Desenvolvimento de Recursos Humanos (Cadrhu), iniciado em 1987, tinha como objetivo exatamente a preparação, em âmbito nacional, de quadros técnico-gerenciais que tinham sob sua responsabilidade a condução dos processos institucionais na área de desenvolvimento de recursos humanos em saúde, de forma a torná-los melhor ajustados aos princípios e propostas da reforma sanitária em curso. Sua proposição foi liderada por representantes da Secretaria de Recursos Humanos do Ministério da Saúde, do Instituto Nacional de Assistência Médica da Previdência Social e da Cooperação Técnica Opas-Brasil. Seu processo de elaboração, que coube a um grupo ad-hoc, liderado pelo Inamps, com a coordenação operacional do Núcleo de Estudos de Saúde Pública/UNB e Núcleo de Estudos de Saúde Coletiva/UFMG, contou com a participação de gestores, acadêmicos e profissionais de diversas instituições dos campos da saúde e da educação, e, em especial, das equipes dos núcleos de saúde coletiva. Tais núcleos de saúde coletiva, os departamentos de medicina preventiva da Universidade Federal da Bahia e da Universidade de São Paulo, assim como a Escola 
Nacional de Saúde Pública, constituíram a base operacional necessária para que fosse empreendido um processo de gradativa descentralização da realização dos cursos no vários estados da federação ${ }^{54}$ (Cadrhu, 1991: 5-12).

Em sua versão inicial, o Cadrhu compreendia um total de 225 horas/ aula, correspondendo às exigências de então para um curso de atualização. Foi dirigido essencialmente a dirigentes e técnicos de recursos humanos de todo o país. Sua estrutura geral se baseou em cinco eixos temáticos, que em seu conjunto conformavam o próprio escopo da área de desenvolvimento de recursos humanos. Eram eles: (1) política de saúde e recursos humanos, discutindo a inserção dos recursos humanos na reforma sanitária brasileira, considerada como movimento político; (2) força de trabalho em saúde, relativo à composição, distribuição e usos do trabalho em saúde; (3) preparação de recursos humanos, voltado para análise recente dos processos de preparação de pessoal, em especial das suas estratégias e métodos pedagógicos; (4) administração de pessoal de saúde, concernente aos temas da administração burocrática do pessoal de saúde, principalmente no âmbito da administração pública; e, por fim, (5) planejamento de recursos humanos, dando conta de concepções, métodos e técnicas para a programação de recursos humanos (Cadrhu, 1991: 5-6).

Seu modo de organização compreendia uma Coordenação Nacional, responsável pela programação do curso, pelos seus aspectos pedagógicos e pela articulação interinstitucional necessária para seu funcionamento; uma Coordenação Temática, composta por especialista de várias instituições e cuja responsabilidade envolvia o desenvolvimento dos conteúdos e estudos de cada eixo temático; e uma Coordenação do Curso, que era responsável pela execução administrativa do curso na instituição imediatamente responsável pela sua realização.

A Coordenação do Curso coube, no primeiro ano de realização, ao Nescon-MG, sendo Sábado Nicolau Girardi responsável pela coordenação executiva. No ano seguinte esta função foi transferida ao Nesp-DF, sob coordenação de Alina Maria de Almeida. Uma assessoria técnica da coordenação de curso era composta por Joana Azevedo e Tânia Celeste Mattos Nunes,

54 Em 1987, participaram diretamente das atividades do Cadrhu o Núcleo de Saúde Coletiva (Nescon) da UFMG; o Núcleo de Estudos de Saúde Pública (Nesp), da UNB; o Núcleo de Saúde Coletiva (Nesco), sediado na Universidade Estadual de Londrina (PR); o Departamento de Medicina Preventiva (Ufba) e a Ensp/Fiocruz. No segundo ano esta rede foi ampliada com a participação dos núcleos de saúde coletiva de Pernambuco (Nesc/Fiocruz); e da Paraíba (UFPB). Em 1990, esta rede passa a contar também com a Escola de Saúde Pública do Rio Grande do Sul, com o Nesc do Ceará (UFCE), com o Nesc do Rio Grande do Norte (UFRN); e com o Nesc de Mato Grosso e Goiás (Cadruh, 1991: 8, 74-75). 
representando a SRH-MS; e Izabel dos Santos, Francisco Lopes e José Paranaguá, indicados pela Cooperação Técnica Opas-Brasil ${ }^{55}$.

O desenvolvimento do Cadrhu nos seus três primeiros anos ocorreu segundo dois eixos, articulados entre si. Ao mesmo tempo em que se realizavam os cursos nos estados - e para que fosse possível promover a sua descentralização - procurou-se também dar atenção estratégica à preparação do pessoal docente, tanto dos coordenadores de curso em cada instituição, como dos coordenadores de cada área temática e dos seus grupos de professores especializados. Ao longo dos três anos, a realização de seminários e oficinas técnicas em torno de cada um dos eixos temáticos propiciava oportunidade e meios para a definição de conteúdos e de estratégias pedagógicas comuns, assim como para o estabelecimento de novas conexões entre as instituições universitárias da saúde coletiva e o domínio das praticas de gestão dos serviços, em especial no que concerne ao planejamento, preparação e gestão de recursos humanos em saúde.

Como já sinalizado, o Cadrhu expandia o número de alunos ao mesmo tempo em que empreendia seu movimento de descentralização. Nos três anos iniciais foram cerca de 730 egressos, provenientes de 24 estados e do Distrito Federal, de uma série de 29 cursos realizados sob a responsabilidade de 12 núcleos nas instituições de ensino e pesquisa, em igual número de unidades da federação. Para tanto, estes cursos mobilizaram mais de uma centena de professores convidados (Cadrhu, 1991: 6-8).

Ao mesmo tempo em que a oferta de cursos era crescentemente realizada nos estados, aumentava no corpo discente a presença dos técnicos oriundos das secretarias estaduais e municipais de saúde. Uma análise comparada do número de egressos por sua origem institucional revela que um paulatino aumento do número relativo de quadros provenientes do nível municipal correspondia à redução dos alunos oriundos da esfera estadual e, principalmente, do Inamps. Deste modo, a descentralização que então se realizava no contexto mais geral do sistema de saúde terminava por se expressar na composição da clientela do Cadrhu.

\footnotetext{
55 José Paranaguá de Santana deixara as suas funções no Inamps, em maio de 1988, como parte do episódio da saída de Hésio Cordeiro da Presidência deste órgão. Foi como Diretor de Modernização Administrativa e Desenvolvimento de Recursos Humanos que ele participou da Coordenação Nacional do Cadrhu nos seus primeiros anos. A partir de 1988, retorna às suas atividades junto à Cooperação Técnica Opas-Brasil, continuando a participar da coordenação como quadro indicado pela Opas-Brasil.
} 
Havia uma nítida predominância de enfermeiras na composição das turmas, seguida à distância pelos assistentes sociais, por graduados em administração e psicólogos. Este predomínio era acompanhado de uma presença minoritária de médicos e odontólogos. Geralmente, o alunado revelava, porém, uma importante heterogeneidade, tributada a uma característica da composição inespecífica do próprio corpo funcional normalmente dedicado aos temas dos recursos humanos em saúde, uma vez que mais de $2 / 3$ dos alunos ocupavam-se destas funções em suas instituições de origem (Cadrhu, 1991: 8-9).

Cada uma das áreas temáticas - e da sua equipe de coordenadores teve sua própria dinâmica no desenvolvimento de conteúdos e de treinamento técnico-pedagógico. Regra geral este processo de capacitação docente envolvia a mobilização de núcleos de competência que por meio de seminários, oficinas e cursos de curta duração constituíam uma equipe docente em nível regional ou estadual, em um movimento que também envolvia o incentivo à pesquisa e produção de conhecimento.

Para o tema (2), referente à força de trabalho em saúde, por exemplo, este processo, sob a coordenação da Ensp/Fiocruz e do Nescon/UFMG, envolveu a realização de um curso com a participação de docentes de vários núcleos e instituições. Entre os temas abordados, incluíram-se a produção de serviços e o mercado de trabalho em saúde; estrutura da força de trabalho e a dinâmica do emprego em saúde no Brasil, entre outros. Admitia-se que os seus resultados compreenderam não só a formação de docentes para o desenvolvimento do Cadrhu, como o próprio desenvolvimento da pesquisa em torno destes temas. Dentre os temas mais problemáticos um dos relatórios do curso foi explícito em indicar o tema (4), relativo à administração de pessoal de saúde. Esta dificuldade pode ser em boa medida creditável ao que seria um menor grau de institucionalidade e sistematização do conhecimento nesta área, em um cenário institucional em acelerada mudança associada ao próprio processo de redemocratização (Cadrhu, 1991: 10-11).

Paralelamente, na Ensp/Fiocruz, também com o apoio do Inamps, era fornecido, como parte da iniciativa Cadruh, um curso de especialização em recursos humanos, por iniciativa da professora Elza Paim, em certo sentido antecipando-se aos futuros desenvolvimentos do programa. Ao mesmo tempo, constituía-se e consolidava-se o Núcleo de Recursos Humanos em Saúde (Nerhus-Ensp/Fiocruz), também com o apoio da Cooperação Técnica Opas-Brasil, como um lugar institucional de desenvolvimento da investigação em RH e Saúde. 
O ritmo de desenvolvimento do Cadrhu sofreria uma sensível redução em 1990 e 1991. Simultaneamente, propunha-se a ampliação da sua carga horária formal - com a sua conseqüente elevação ao status de curso de especialização - e as suas lideranças institucionais empreendiam um processo de revisão conceitual e metodológica.

As restrições experimentadas foram o resultado de uma conjugação de fatores, entre os quais se incluíam a redução da disponibilidade de recursos para o seu financiamento e o já expressivo contingente de trabalhadores já titulados (Castro \& Santana, 1999: 18-19). Há que se considerar, ainda, que àquela altura, já durante o governo de Fernando Collor de Mello, o setor público brasileiro encontrava-se em franco e tumultuoso processo de desmontagem, sob o império das concepções liberais acerca do seu papel, com profundas implicações sobre a sua forma de organização e funcionamento.

$\mathrm{Na}$ altura de finais da década de 1980, eram expressão do legado da Cooperação Técnica Opas-Brasil - pelo menos em parte - quatro das mais dinâmicas áreas do desenvolvimento de recursos humanos no Brasil: (1) a ampliação e nova institucionalidade do Projeto Larga Escala, representada pela gênese e desenvolvimento daquela que seria a Rede de Escolas Técnicas do SUS; (2) a maior articulação em rede dos projetos de integração docenteassistencial, inclusive com sua aproximação às iniciativas empreendidas pela Fundação Kellogg no âmbito dos projetos UNI; (3) a experiência com a capacitação dirigida aos gestores de recursos humanos nos estados e municípios; e (4) a rede de núcleos de estudos de saúde coletiva como base para a constituição do campo como área de conhecimento. De uma forma ou de outra, estes desenvolvimentos correspondiam a um acúmulo de aquisições e sucessivas reconfigurações, baseadas na experimentação concreta de várias ações, realizadas ao longo da trajetória iniciada em 1975.

À guisa de conclusão vale a pena retomar os principais passos desta trajetória.

\section{O Legado da Cooperação Técnica em Perspectiva}

Em meados da década de 1970, uma conjugação de fatores propiciou uma articulação de interesses entre o governo autoritário brasileiro, a Opas, uma emergente elite técnica e um nascente movimento reformador da saúde. 
Para a Opas, significava ampliar sua capacidade de atuação no Brasil, de promover a adoção de uma agenda mais ou menos consensuada em torno dos temas dos recursos humanos e, ao mesmo tempo, ensaiar modelos alternativos de cooperação técnica.

Para o governo brasileiro, num contexto de crise política, significava a possibilidade de ampliar suas esferas de atuação no que concerne às políticas sociais, e imprimir maior racionalidade ao provimento dos serviços de saúde, então em processo de expansão. As novas elites técnicas, de vários matizes políticos, de certa forma autoproclamadas paladinas da racionalidade, ansiavam por espaços institucionais permeáveis às suas proposições e, de preferência, onde pudessem exercer suas competências com crescente grau de autonomia. O movimento sanitário, em sua perspectiva reformadora, vislumbrava a oportunidade de ocupar postos de governo, de mobilizar recursos políticos e operacionais e, destas novas posições, fortalecer a própria reforma na Saúde.

Estas fontes de interesses enunciadas esquematicamente, de certa maneira, definem o contorno da Cooperação Técnica Opas-Brasil em Recursos Humanos como arena de negociação e interação. Nela, nossos atores reais, conformaram-se como personagens compostos. A própria equipe do GTC, do GAP, assumiu mesmo esta identidade, "anfíbia", nos termos de um dos seus membros.

Sem dúvida, no período estudado, a Cooperação Técnica repercutia no contexto brasileiro as doutrinas, os princípios e as normas presentes nas formulações da Opas, quanto à organização dos serviços de saúde, às suas conexões com o processo de desenvolvimento, quanto às políticas de recursos humanos adequadas. A Cooperação Técnica era parte do aparato do desenvolvimento - tanto como ideologia, quanto como materialidade - expresso na Organização Pan-Americana da Saúde.

A Cooperação Técnica era também um lugar de recepção ativa desses enunciados; do seu reprocessamento e reenunciação à luz da experiência local dos seus personagens. Ao operar dessa maneira, foi marcadamente eficaz em sua capacidade de, com significativo grau de autonomia, influir e, eventualmente, modelar as políticas nacionais e a própria constituição de espaços e redes institucionais de conformação do campo da saúde coletiva e do desenvolvimento de recursos humanos. Todavia, esta capacidade se restringiu à sua dimensão nacional.

A experiência especificamente brasileira no terreno do desenvolvimento de recursos humanos não foi capaz de disseminar-se em larga medida para 
o contexto regional latino-americano, segundo os testemunhos de alguns de seus principais personagens. Afora algumas contribuições inovadoras no terreno da pesquisa em recursos humanos, pode-se dizer que houve mesmo uma espécie de dissonância entre esta limitação e a própria trajetória políticoinstitucional de Carlyle Guerra de Macedo, rumo à direção da Opas, um percurso depois seguido por vários dos componentes da equipe pioneira. São conhecidos os constrangimentos de ordem histórico-cultural entre o Brasil e seus vizinhos de continente. Entretanto, os principais entraves devem ser encontrados na singularidade do processo político-institucional da saúde no contexto brasileiro, no que concerne às expectativas com relação ao papel do Estado e das políticas públicas às vésperas da voga neoliberal.

O Acordo Geral para a Formação de Recursos Humanos para a saúde no Brasil, como seu título indica, possuía um explícito foco nos temas de recursos humanos. Este escopo, contudo, jamais foi percebido de modo circunscrito, descolado das suas relações com o funcionamento dos serviços, da ampliação da sua cobertura, do compromisso com uma maior racionalidade e com a própria reforma do setor. Mais do que isso: a frente de trabalho voltada para constituição das regiões docente-assistenciais, por exemplo, comportava, desde a primeira hora, a expectativa de promover, ao fim e ao cabo, a própria reorganização dos sistemas e serviços de saúde.

Este componente, mais diretamente orientado para os temas da organização dos sistemas e serviços de saúde, iria assumir aos poucos uma dimensão relativamente mais importante no interior da Cooperação Técnica. Este movimento de transbordamento do objeto original é identificável desde os primeiríssimos anos do Acordo e do Ppreps. Em certa medida, é possível considerar que o "Ppreps-invisível", tal como referido na memória dos pioneiros, isto é, como o lugar privilegiado de uma agitação reformadora, antecipava uma vocação de fato orientada para o conjunto das questões atinentes à estrutura e ao funcionamento dos serviços de saúde.

A cada aditivo, todavia, a cooperação técnica incorporava novos parceiros, remodelava o arranjo institucional original e ampliava formalmente seu escopo de atuação. É possível identificar na gestação do Prev-Saúde, um marco fundamental nesta direção, ao mobilizar o GAP para a modelagem de uma alternativa universalizante de atenção à saúde para o sistema de saúde brasileiro.

Em sua trajetória peculiar, no contexto da crise da ditadura e da transição democrática, a Cooperação Técnica assumiu, por um lado, o papel de reserva e meio de recrutamento de competências políticas e técnicas, para um 
regime que se pretendia mais racional e eficaz, ao mesmo tempo em que engendrava as formas de renovar suas condições de reprodução. De outro, foi também uma plataforma para a ação política, para auxiliar a mobilização que pretendia o duplo e articulado objetivo de tanto realizar a reconquista democrática quanto de transformar as práticas institucionais em saúde. Neste sentido a Cooperação Técnica reproduzia, no domínio dos recursos humanos em saúde, um processo que igualmente se verificava em outras agências do Estado brasileiro e outras arenas da vida social.

Do ponto de vista das estruturas do governo brasileiro, a trajetória da Cooperação Técnica registrou uma progressiva ampliação no número de pastas ministeriais e de outros órgãos que compunham sua base institucional. Este processo, porém, não se deu de maneira uniforme. Ele esteve sujeito a oscilações no grau de compromisso e da disponibilidade de recursos dos ministérios envolvidos. Seja como for, o movimento representado pelo Ppreps e seus sucedâneos foi parte de um esforço, relativamente bem sucedido, no sentido de uma maior integração entre órgãos de governo na esfera federal, no terreno dos recursos humanos.

Seus resultados parecem ter sido ainda melhores como parte do processo de descentralização e de reforço das áreas de competência técnica e científica nos níveis estaduais e mesmo locais. São exemplos categóricos deste movimento centrífugo: a criação dos Núcleos de Desenvolvimento de Recursos Humanos nas secretarias estaduais de saúde; o estímulo ao desenvolvimento dos Núcleos de Saúde Coletiva nas universidades; a instituição de centros de formação e capacitação de pessoal de saúde nos estados; a operação descentralizada do Cadrhu; entre outras experiências. Mesmo em seus dificultosos percursos, os projetos IDA compreendiam sempre um componente de descentralização, inclusive, promovendo a participação das comunidades na definição de rumos, estratégias e metas. Ao fazê-lo, a Cooperação Técnica Opas-Brasil em Recursos Humanos desempenhou um papel decisivo tanto na conformação da arquitetura institucional, como da própria rede de profissionais que na atualidade configuram o desenvolvimento de recursos humanos para a saúde no país. 


\section{Parte II. Depoimentos}




\title{
6. Diálogos com os Pioneiros
}

\author{
Com a co-autoria de Gilberto Hochman*, \\ Janete Lima de Castro** e Regina Celie Simões Marques***
}

Para Francisco Lopes

“Diálogos com os Pioneiros" reúne depoimentos editados dos profissionais brasileiros, que, a partir de meados de 1970, foram precursores na concepção do acordo interinstitucional e na composição da primeira equipe de trabalho da cooperação técnica entre a Opas e o governo brasileiro no desenvolvimento de recursos humanos para a saúde.

Entre os meses de fevereiro e dezembro de 2005, foram colhidos os depoimentos dos médicos brasileiros que compunham este grupo: Alberto Pellegrini Filho, Carlyle Guerra de Macedo, Cesar Vieira, Danilo Prado Garcia, José Roberto Ferreira, José Paranaguá de Santana e Roberto Nogueira. Nestes encontros, participaram, como entrevistadores, Carlos Henrique Assunção Paiva, Fernando Pires-Alves, Gilberto Hochman, Janete Lima de Castro e Regina

\footnotetext{
Gilberto Hochman, pesquisador da Casa de Oswaldo Cruz (Fiocruz), é bacharel em Administração Pública pela Fundação Getúlio Vargas, mestre e doutor em Ciência Política pelo Instituto Universitário de Pesquisa do Rio de Janeiro (Iuperj).

* Janete Lima de Castro é professora associada da Universidade Federal do Rio Grande do Norte (UFRN) e enfermeira da Secretaria Municipal de Saúde de Natal/RN. Mestre em Administração e doutoranda no Programa de Pós-Graduação em Educação na UFRN, é Coordenadora do Observatório de Recursos Humanos do Nesc/UFRN.

*** Regina Celie Simões Marques, tecnologista da Casa de Oswaldo Cruz (Fiocruz), é bacharel em Ciências Sociais pela Universidade do Estado do Rio de Janeiro (Uerj) e mestre em Ciência da Informação pelo Instituto Brasileiro de Informação Científica \& Tecnológica (Ibict).
} 
Celie Marques. A enfermeira Izabel dos Santos, personagem igualmente decisiva para os rumos da Cooperação, já havia sido entrevistada por Janete Castro, José Paranaguá de Santana e Roberto Nogueira, em uma iniciativa que resultou na publicação de Izabel dos Santos: a arte e a paixão de apreender faz̨endo, em 2002.

Este conjunto de depoimentos foi objeto de uma seleção e edição segundo um conjunto de questões consideradas relevantes para a trajetória da Cooperação Técnica e para o desenvolvimento de recursos humanos em saúde, assim como para o contexto de sua ocorrência. Agradecemos, portanto, a Janete Castro, José Paranaguá e Roberto Nogueira a oportunidade de utilizar o depoimento de Izabel dos Santos com este propósito. Esta iniciativa ficaria incompleta sem esta possibilidade. Como de alguma maneira fica sem o depoimento de Francisco Lopes, já falecido. Sua presença foi, contudo, freqüentemente lembrada pelos seus ex-companheiros ${ }^{56}$.

A edição dos depoimentos produziu uma espécie de conversa hipotética entre todos os personagens em um percurso que versa sobre a ação da Opas nas Américas e no Brasil; o desenvolvimento e o adensamento das discussões sobre RH em saúde; o desenvolvimento da cooperação técnica em recursos humanos; as suas conseqüências previstas e não esperadas; sua conexão com o movimento sanitário que desembocaria na criação do Sistema Único de Saúde, bem como sobre o estado da cooperação técnica em nossos dias e as suas perspectivas.

Historiadores profissionais costumam designar este tipo de trabalho como "Memória", frequentemente em distinção à noção de "História". A discussão em torno dos significados de ambas expressões não provoca apenas interesse particular para aqueles que têm a compreensão do homem no tempo como seu métier, isto é, os historiadores e os demais pesquisadores afins. Hoje em dia, grande parte daqueles que se devotam a pensar estas questões concordam que a Memória não pode ser vista simplesmente como um processo parcial e limitado de lembrar fatos passados, de pequena relevância para a compreensão dos processos históricos. Trata-se, antes, da construção de referenciais sobre o passado, o presente e o futuro realizada pelos diferentes grupos sociais, de modo sempre referido a determinadas tradi-

56 A rigor, Regina Coeli Nogueira foi também uma pioneira da Cooperação Técnica Opas-Brasil em Recursos Humanos. Regina, porém, desligou-se muito precocemente da equipe durante os primeiros anos da década de 1980, afastando-se profissionalmente da Opas e, aparentemente, dos temas da Saúde e dos Recursos Humanos. 
ções, ainda que tais grupos se considerem comprometidos com mudanças políticas e/ou sociais.

Nesse sentido, Memória pode ser encarada como um exercício de retomada do passado, de reflexão acerca do que foi feito ou dito por alguém em determinada época pretérita. Trata-se de uma reorganização mental, à luz de determinado presente, do como e do por que determinados fatos se passaram de tal maneira e não de outra. Memória, em síntese, não é apenas um exercício individual, ela é, como nos fazem entender estudiosos como Maurice Halbwachs e Pierre Nora, partilhada, transmitida e também construída pelos grupos sociais.

Neste sentido, a Memória pode ser matéria dos historiadores, como fonte histórica. Matéria que deve ser cruzada com fatos e informações muitas vezes ignorados pelos que se lembram, mas que ao historiador caberia a tarefa de contextualizar ou estabelecer inter-relações. Pode e deve ser também um exercício de reconhecimento de experiências sociais comuns, da sua atualização como acervo coletivo. Sugere-se que a edição dos depoimentos que será apresentada a seguir possa ser lida dessa dupla perspectiva. Da mesma forma, o conjunto integral de cada entrevista realizada que, uma vez revistas pelos depoentes, passarão a integrar o acervo do Departamento de Arquivo e Documentação da Casa de Oswaldo Cruz, na Fundação Oswaldo Cruz.

Na altura da metade da década de 1970, a cooperação técnica em recursos humanos em saúde resultou de uma articulação entre a Organização Pan-Americana da Saúde (Opas) e o governo brasileiro. Como o tema era então considerado em termos organizacionais e programáticos na agenda da organização?

José Roberto Ferreira - A Opas, em sua sede, contava com um Departamento de Educação e Treinamento, que mais adiante passou a chamar-se Programa de Educação Médica. Em 1967, ele foi oficialmente transformado em Departamento de Desenvolvimento em Recursos Humanos e, como tal, uma de suas primeiras ações foi a realização, em Maracay, de uma Primeira Conferência de Recursos Humanos em Saúde - que, com o patrocínio da Opas e da Fundação Millbank, deu grande ênfase a planificação de recursos humanos na América Latina e levou à realização do grande estudo de Recursos Humanos e Educação Médica, realizado na Colômbia e, depois, parcialmente na Argentina. Isso em si já mostra uma evolução: começou com treina- 
mento e educação, passou pela educação médica e daí a recursos humanos. Mas, ainda assim, tratava-se essencialmente de educação médica, talvez um pouco de odontologia também. A enfermagem tinha um programa à parte, manejado pelo Departamento de Serviço de Saúde. A engenharia sanitária ficava a cargo do Departamento de Engenharia Sanitária. Só em 1975 houve a integração dessas áreas de formação, com o Programa de Desenvolvimento de Recursos Humanos, quando eu estava na chefia do programa. [...]

Eu enfrentei a tarefa, que me foi dada pelo [Hector] Acuña $a^{57}$, de ampliar o Departamento de Recursos Humanos. Na época éramos basicamente eu e mais três outros profissionais e um grupo de funcionários responsáveis pelo Programa de Bolsas de Estudos, mais dois consultores. Mas, com a chegada ao departamento do pessoal de enfermagem, odontologia, engenharia sanitária, veterinária, o programa começou realmente a cobrir o campo de recursos humanos. Algumas dessas áreas se integraram mais facilmente do que outras. Enfermagem foi a mais fácil. Já tínhamos criado no Brasil o Nutes/Clates [Núcleo de Tecnologia Educacional para a Saúde/Centro Latino-Americano de Tecnologia Educacional], e a nossa primeira medida foi criar um programa semelhante para enfermagem. Com isso a enfermagem se sentiu muito prestigiada, porque estava sendo tratada no mesmo nível que a educação médica, e integrou-se rapidamente. A engenharia sanitária também não foi um grande problema, apesar de eles terem uma orientação diferente. Tinha sido criada, no Peru, uma escola de engenharia sanitária — até hoje a única existente na América -, e eles funcionavam muito atrelados a ela. Veterinária praticamente nunca se integrou, nem odontologia, e o Acuña preocupava-se muito com isso. A área de odontologia fez muito pouco em matéria de educação; ela dedicava-se mesmo a campanhas para pós-graduações. E a de veterinária empenhou-se na questão da competência; eles foram os primeiros a trabalhar, no departamento, com a competência de ensino e educação.

Trabalhávamos assim, sem uma integração real e total. Uma das providências que tomamos para promover essa integração foi a organização dos Talleres de Educação em Ciências de Saúde. Foram cinco seminários, realizados uma vez por ano, em que participaram o nosso staff, incluindo o Juan

57 Héctor Acuña, à época, era Diretor da Opas. Nascido no México em 1921, graduou-se em medicina pela Universidade Nacional Autônoma do México, em 1947, e titulou-se mestre em Saúde Pública pela Universidade de Yale, em 1951. Acuña dirigiu a Opas entre 1975 e 1983 , sucedendo a Abraham Horwitz. 
César García ${ }^{58}$, Miguel Márquez ${ }^{59}$ e outros. Eram eventos muito dinâmicos, dirigidos especificamente para diretores de escolas e profissionais de saúde. Reuníamos cerca de 20 participantes em cada seminário, que durava de dois a três meses. Eles eram levados para Washington e durante esse período trabalhavam sobre uma cidade fictícia. $\mathrm{Na}$ realidade todos os dados eram baseados em El Salvador, só que ninguém sabia. A missão era planejar a situação de recursos humanos daquela cidade, incluindo a abertura de escolas, organização de cursos, o que fosse necessário. Esses talleres talvez tenham sido um dos mecanismos que mais ajudaram na nossa integração, e deles participaram pessoas que depois vieram a assumir posições destacadas na América Latina.

Nos anos 1960/70, de que maneira os temas dos recursos humanos em saúde se integravam à agenda mais geral do desenvolvimento nas Américas?

José Paranaguá - Em 1972, quando houve a Reunião de Ministros de Saúde das Américas, o tema mais importante foi o de recursos humanos. Embora a reunião fosse para discutir o [Segundo] Plano Decenal de Saúde para as Américas, o eixo desse plano de saúde é, praticamente, responder às necessidades que, naquela época, se consideravam muito defasadas no investimento em formação de pessoal; entre disponibilidade de pessoal e as necessidades de atendimento à saúde nos países do conjunto das Américas. Isso tudo tem, inclusive, muito a ver com a criação, no Brasil, no Ipea [Instituto de Pesquisa Econômica Aplicada], no Ministério do Planejamento, aliás, na época, chamava Secretaria de Planejamento da Presidência da República, do CNRH, do Centro Nacional de Recursos Humanos. E a criação, também, no Ministério da Saúde, da Secretaria de Recursos Humanos, em 75. Então, essas coisas estão ligadas umas às outras.

Cesar Vieira - Na Conferência de Punta del Este [1961] — onde foi lançada a Aliança Para o Progresso - a Opas e os ministros de Relações Exteriores, Finanças e Planejamento chegam à seguinte conclusão: saúde é algo importante e não pode ficar fora do processo de desenvolvimento regional e

\footnotetext{
58 Juan César Garcia, médico e sociólogo argentino, é considerado um dos precursores no campo dos estudos sociais da saúde. Nos anos 1960/70, atuando na Opas, desempenhou um papel-chave no desenvolvimento da área de recursos humanos em saúde.

59 Médico equatoriano, Miguel Márquez é um dos precursores do ensino técnico em saúde na América Central e Caribe. Foi representante da Opas em Cuba e na Nicarágua.
} 
de planejamento, então vamos fazer um projeto para incorporar o planejamento de saúde ao plano de desenvolvimento. $\mathrm{Na}$ época eles acharam interessante a experiência venezuelana do Cendes, Centro de Estudos de Desenvolvimento, e recorreram ao método de planejamento desse centro para criar um segmento de saúde que ficou conhecido como Cendes-OPS. E foi montado, no Ilpes [Instituto Latino Americano e do Caribe de Planejamento Econômico e Social], Chile, um centro parecido com o projeto do Ppreps [Programa de Preparação Estratégica de Pessoal de Saúde]. Raúl Vargas ${ }^{60}$, Carlyle Macedo e Américo Migliónico foram trabalhar lá e formaram centenas de pessoas na área de planejamento em saúde. O Carlyle havia trabalhado na Sudene [Superintendência de Desenvolvimento do Nordeste], integrando a equipe de saúde, com o Mozart de Abreu e Lima; depois foi trabalhar na secretaria de Saúde do Piauí - ele foi secretário ainda recém-formado ${ }^{61}$. Dali foi para Santiago do Chile, no convênio do Ilpes com a Opas.

Carlyle Guerra de Macedo - Depois da reunião de Punta del Este e da Aliança para o Progresso, começou a haver uma pressão dos Estados Unidos para que todas as instituições interamericanas, e até as próprias Nações Unidas, aderissem à proposta do planejamento. A Opas aderiu com todo entusiasmo, e promoveu a criação de um grupo na Universidade de Venezuela para criar uma metodologia de planejamento em saúde que respondesse aos fundamentos da Aliança para o Progresso.

O grupo formulou então uma metodologia de programação, a CendesOPS, para os cursos que formariam pessoal para elaborar os planos de saúde que a Aliança apoiaria. A metodologia é muito matemática, porque transfere para o planejamento em saúde o que predominava então na teoria econômica quanto ao crescimento econômico. Ela é muito pobre com relação a praticamente todos os outros fatores que estavam fora desses parâmetros. Os recur-

${ }_{60}$ Estatístico peruano, Raúl Vargas integrou a equipe de formulação do método Cendes-OPS, uma metodologia referencial para o planejamento em saúde durante os anos 1960 e 1970 e desenvolvida mediante de cooperação entre o Centro de Estudos do Desenvolvimento, da Universidade Central da Venezuela, e a Opas.

${ }^{61}$ Mozart de Abreu e Lima formou-se em odontologia (1960) e administração de empresas (1971) pela Universidade Federal de Pernambuco. Integra uma geração de profissionais ligados ao Centro de Planejamento sobre a América Latina (Cepal) e à área de planejamento da Opas. Trabalhou na Superintendência de Desenvolvimento do Nordeste (Sudene) na década de 1960, na Central de Medicamentos (Ceme) e no Instituto Nacional de Alimentação e Nutrição (Inan) até 1978. Foi Secretário-Geral do Ministério da Saúde durante a gestão do Ministro Waldir Arcoverde, entre 1979 e 1985. Ver http://www.bvshistoria.coc.fiocruz.br/polio/brasil/acervo/ memoriaPoliomielite/mozartLima.htm. (Acesso em 31.07.2006) 
sos humanos são pouco considerados, só entram como fator de produção para instrumentar - a palavra usada era esta — as ações de saúde. A racionalidade era a do capital e da tecnologia; a política era um fator neutro, não se considerava adequadamente sua importância - e esta era uma crítica central que eu fazia à metodologia. [...] A sociedade é muito mais complexa, e não bastava obedecer àquelas recomendações que brotavam de determinadas fórmulas, por mais sofisticadas que fossem. Nós trabalhávamos muito com métodos matemáticos para representar o que aconteceria na sociedade. Para nós, no Centro Pan-americano de Planejamento de Saúde, a idéia de um modelo matemático que representasse a realidade era algo útil para organizar as ações sobre essa realidade.

Roberto Nogueira - O método Cendes-OPS é hoje considerado uma forma muito rígida e burocrática de fazer planejamento. Os diagnósticos que ele exigia eram exaustivos e caros. Levantavam-se dados de morbidade e mortalidade da área, todos os serviços e unidades de saúde, número de leitos e recursos humanos em cada unidade. Isso implicava aplicar formulários de cidade em cidade, de local em local. E depois que se reunia aquele mundo de dados, vinha a pergunta: "Como eu integro tudo isso?".[...]

O método tem a ver com o [Primeiro] Plano Decenal de Saúde Pública, que foi feito em 1961. Para o Plano eles fizeram diagnósticos desse tipo exaustivo em alguns países, como o Peru, Chile e México. Havia um consenso de que era muito necessário ter informações adequadas, então existe sim uma conexão entre o método Cendes-OPS e essa linha de planejamento normativo e exaustivo em matéria de estatística, que predominava naquela época.

José Paranaguá - A literatura produzida na década de 1970 tem uma visão de recursos humanos como fator de produção, destaca a importância econômica de recursos humanos tanto nos setores da economia quanto da agricultura e tudo o mais. Nesse período houve, no Brasil, uma grande expansão da educação técnica, agrícola e industrial. Então, não há nenhuma peculiaridade no investimento que foi feito no campo da saúde com recursos humanos. A preocupação era exatamente essa. O Ppreps, consubstanciado no plano de trabalho do acordo da Opas com os ministérios, era um projeto para melhorar a articulação entre a universidade e os serviços de saúde, formar gente de nível médio e desenvolver a capacidade institucional das secretarias de saúde na área de recursos humanos. 
O Acordo de cooperação, a criação e atuação do Ppreps correspondem ao período de introdução e fortalecimento da medicina social e da saúde coletiva, como a Opas participon deste processo?

José Roberto Ferreira - A partir de meados da década de 1970 nós, na Opas, começamos um trabalho mais intenso com as escolas de saúde pública. A Opas havia reunido pela primeira vez as nove Escolas existentes em 1959, em uma reunião em São Miguel Regla, no México e, daí se seguiram reuniões cada dois anos, revisando o conteúdo de cada uma das disciplinas tratadas naquele contexto. Em 1974, a reunião realizada no Peru, já com um número mais significativo de Escolas, promoveu a criação da Associação Latino-Americana de Escolas de Saúde Pública (Alaesp). A partir de então, passou-se a uma análise mais geral da formação em saúde pública introduzindose, nessa área, um esforço de investigação, que até então vinha ocorrendo nos Departamentos de Medicina Preventiva e Social. Um aspecto interessante dessa evolução foi a regionalização do ensino da saúde pública, que se desenvolveu no Brasil, com o apoio da Ensp e as iniciativas das Secretarias de Saúde dos Estados com as universidades locais, estratégia que conduziu a um aumento do número de cursos e um desafogo das duas Escolas mais tradicionais, do Rio de Janeiro e de São Paulo.

O trabalho do Ppreps nessa área favoreceu, em 1979, a criação da Abrasco [Associação Brasileira de Pós-Graduação em Saúde Coletiva], a qual se transformou nos dias atuais na principal associação de saúde pública do país. Quando Hésio Cordeiro ${ }^{62}$ assumiu a Previdência Social, levou o [José] Paranaguá - que estava no Ppreps, para coordenar a área de recursos humanos - e, ele, com recursos financeiros da Previdência Social, promoveu o estabelecimento dos Núcleos de Saúde Coletiva, em um momento em que também se desenvolviam as residências de saúde coletiva. Embora o Ppreps não tivesse uma articulação direta com a Previdência Social, este desenvolvimento ocorreu por influência de um funcionário que vinha da Opas, trazendo a orientação que predominava naquele contexto.

62 Hésio de Albuquerque Cordeiro é mineiro de Juiz de Fora, nascido em 22 de maio de 1942. Titulou-se em 1965 na Faculdade de Ciências Médicas da Universidade do Estado do Rio de Janeiro (Uerj). Integrou a equipe de fundação do Instituto de Medicina Social (IMS), também da Uerj. No IMS, coordenou o Mestrado em Medicina Social e exerceu o cargo de Diretor, entre 1983 e 1985. Foi presidente da Associação Brasileira de Pós-Graduação em Saúde Coletiva. Membro das equipes de transição do presidente eleito Tancredo Neves, entre 1985 e 1988 presidiu o Instituto de Assistência Médica da Previdência Social. Atualmente é Diretor da Faculdade de Medicina da Universidade Estácio de Sá. Ver: http://www.scielo.br/scielo.php?pid=S0102311X1988000300010\&script=sci_arttext\&tlng=pt (Acesso em 01.08.2006) 
Em toda a América Latina, o número de Escolas cresceu para mais de 120 , nos dias atuais, e com isso tornou-se impossível manter o esquema das reuniões a cada dois anos. Passamos a promover eventos mais focalizados em determinadas regiões ou escolas, ampliando dessa forma o trabalho com todas as Escolas. Junto com a Associação Americana de Escolas de Saúde Pública, a Opas promoveu um amplo debate centrado na relativa impossibilidade da própria saúde pública em alcançar níveis de saúde adequados. Este esforço levou a publicação de dois livros analisando a "crise da saúde pública" e as possibilidades de superá-la. Mais recentemente, o debate tem se centrado na análise das funções essenciais da saúde pública.

Roberto Nogueira - O coordenador de Recursos Humanos em Washington era José Roberto Ferreira. Essa área tinha uma linha de educação médica - publicava inclusive uma revista, a Educación Médica y Salud. A linha de educação médica se desdobrava em duas. Uma tinha a ver com as ciências básicas, apoiava pesquisas de ponta em desenvolvimento de recursos humanos, como Ribeirão Preto, por exemplo, que tinha uma escola inovadora, com currículos integrados para a formação de médicos. Esse interesse do José Roberto teve origem na Universidade de Brasília, e ele o levou para Washington. A linha apoiou várias iniciativas no continente que buscavam alternativas ao ensino tradicional e muito disciplinar que se tinha na medicina. Quando o Juan César García, que era argentino, foi para Washington, já tinha grande interesse em ciências sociais em saúde, e então ele se voltou mais para o apoio aos mestrados de Medicina Social e Medicina Preventiva na América Latina, o que se tornou também uma linha do programa que o José Roberto dirigia na época. Todas essas linhas integravam a área de formação médica, que sofreu uma reviravolta com a entrada da medicina social, no que diz respeito a políticas de saúde, políticas médicas etc. Isso aconteceu entre o final dos anos 1960 e início dos 1970 e coincidiu com a formação, no Brasil, de vários grupos, como o do IMS e o do Sergio Arouca ${ }^{63}$ em Campinas. [...]

63 Antonio Sérgio da Silva Arouca nasceu em Ribeirão Preto, estado de São Paulo. Formou-se médico em 1966 pela Faculdade de Medicina da Universidade de São Paulo. Foi consultor da Opas, tendo atuado em países como México, Honduras, Costa Rica, Nicarágua, Cuba, Colômbia e Peru. Defende sua tese de doutorado em Medina Preventiva em 1975. No ano seguinte ingressa na Escola Nacional de Saúde Pública. Torna-se Presidente da Fiocruz em 1985. Foi Secretário de Saúde do Estado do Rio de Janeiro e eleito Deputado Federal pelo mesmo estado para duas legislaturas (1990 e 1998). Foi candidato a vice-presidente da República (1989) e Vice-Prefeito do Rio de Janeiro (1992). Ocupou, ainda, a Secretaria de Saúde do Município do Rio de Janeiro (2002) e a Secretaria de Gestão Participativa do Ministério da Saúde, em 2003. Faleceu em agosto deste mesmo ano. Ver: http://bvsarouca.cict.fiocruz.br (Acesso em 01.08.2006). 
José Roberto Ferreira - O Juan César García era muito irrequieto, e quando estava desenvolvendo seu estudo sobre educação médica na América Latina começou também uma série de seminários nacionais. Dois deles ficaram famosos, os seminários de Cuenca, em 1968 e 1978. A partir desses seminários ele promoveu a criação de três programas de pós-graduação em Medicina Social: no Rio de Janeiro (IMS/Uerj), que foi o primeiro, no México (UAN-Xochimilco) e no Equador (UCE). Os três são considerados líderes em medicina social na América Latina. Depois, é claro, foram obtidos recursos de outras fontes, como a Fundação Kellogg, mas esses programas foram basicamente produzidos e criados por Juan César García. No caso do IMS, o Carlos Vidal ${ }^{64}$ participou muito intensamente na criação do programa.

Roberto Nogueira - A primeira turma do IMS começou em 1973, e dela fizeram parte o [João] Regazzi ${ }^{65}$, Hésio Cordeiro e José Noronha ${ }^{66}$, praticamente os fundadores do instituto e que faziam a sua formação ao mesmo tempo que eram professores. Também havia alguns estrangeiros, chamados de becarios da Opas, que eram indicados pelo Juan César García, de Washington. [...] Eles eram de Honduras, Costa Rica, Peru, vários países, e vinham fazer o mestrado em Medicina Social. O curso do México, em Xochimilco, estava começando na mesma época. Os dois mestrados eram apoiados pela Opas, nas figuras de Juan César García e José Roberto.

Formava-se pessoal em áreas estratégicas, e uma delas, talvez a mais importante, era a de saúde pública, ou saúde coletiva, ou medicina social. Essa política estava muito ligada ao nome do Juan César García. [...] Esta foi uma novidade que apareceu no começo dos anos 1970, porque o que se tinha antes era algo muito mais higienista, preventivista — de médicos para médicos. $\mathrm{Na}$

${ }_{64}$ Carlos A. Vidal, integrante do Programa de Desenvolvimento de Recursos Humanos da Organização Pan-Americana da Saúde, em Washington, foi também representante da OPAS no Brasil, em meados dos anos 1970; e em Buenos Aires, Argentina, na década seguinte.

${ }^{65}$ João Regazzi Gerk é médico, formado pela Uerj em 1969. Em 1979 obteve o título de mestre em medicina social pelo Instituto de Medicina Social (IMS/Uerj) da mesma universidade. Foi diretor do IMS e vice-reitor da UERJ. Atualmente é professor-assistente nesta universidade.

${ }^{66}$ José Carvalho de Noronha formou-se em medicina na Universidade Federal do Rio de Janeiro em 1970. É especialista em Saúde Pública pela The Leeds University (1973); mestre em Medicina Social pela Uerj (1978) e doutor em Saúde Coletiva pela mesma universidade (2001). Foi Chefe de Gabinete no Inamps, na gestão Hésio Cordeiro; Secretário de Saúde do Estado do Rio de Janeiro, de 1988 a 1990; foi Diretor do Instituto de Medicina Social da Uerj; presidente da Abrasco entre os anos de 2000 e 2003, e membro do Conselho Nacional de Saúde. Atualmente é médico da Fiocruz e é assessor da Secretaria de Atenção à Saúde do Ministério da Saúde. Ver: Currículo Lattes, em: http://buscatextual.cnpq.br/buscatextual/visualizacv.jsp?id=K4798530A5 (Acesso em 02.08.06). 
década de 1970 começam a perceber que as ciências sociais em saúde dariam uma outra visão a quem atuava nesse campo. Então, é uma linha inovadora a que se inicia com Xochimilco e Uerj [Universidade do Estado do Rio de Janeiro]. Não havia nenhum mestrado anterior nessa área, e foi preciso formar professores e alunos. O grupo da USP [Universidade de São Paulo], com a Cecília Donnangelo ${ }^{67}$, também estava iniciando. Os grupos existentes eram ainda pequenos e débeis. [...]

O Arouca inovou ao trazer a perspectiva das ciências sociais e da epistemologia. Apesar de inserir a medicina mais numa linha de atendimento de massa, ele trouxe uma visão mais crítica, que vem de autores ligados à filosofia e às ciências sociais. Então, quando se criou o mestrado na Uerj, essa orientação já estava presente. Tanto é assim que uma das iniciativas do Juan César, no mestrado, foi trazer grandes vultos como o próprio Michel Foucault e o Ivan Illich, que eram os nossos gurus. Naturalmente o Foucault não era tão conhecido como veio a ser posteriormente, mas já era uma grande expressão da filosofia nessa época. E foi uma oportunidade única para nós, alunos, o contato com esses revolucionários do pensamento.

Carlyle Guerra de Macedo - No final da década de 1970 começou uma discussão sobre formação em saúde pública, cujo ponto central era a definição de uma nova área, Saúde Pública como campo teórico e de prática. Que nome ela teria? Higiene não podia ser; já tínhamos passado a época da higiene. A expressão 'saúde pública' estava um pouco desgastada, e considerávamos a acepção um pouco limitada - estávamos ainda nos prelúdios do movimento sanitário, mas já tínhamos essa avaliação. E a expressão veio. Não sei exatamente quem propôs, mas surgiu na reunião [I Reunião sobre Formação e Utilização de Pessoal de Nível Superior na Área da Saúde Pública]: 'saúde coletiva' parecia ser o que nós queríamos. [...] Com ela queríamos denotar algo que a saúde pública convencional, naquele momento, não alcançava. Saúde coletiva era a saúde da população, a saúde das comunidades. Era ver o ser como indivíduo, em vez de ignorá-lo. Vê-lo imerso em seu contexto, em seu meio, como parte de uma comunidade que, por sua vez, é muito mais que a soma dos indivíduos. Era não pensar somente na saúde individual e, por

${ }^{67}$ Socióloga, paulista de Araraquara, nascida em 1940, Maria Cecília Ferro Donnangelo se destacou como docente e pesquisadora do Departamento de Medicina Preventiva, da Faculdade de Medicina da Universidade de São Paulo. Teve papel decisivo na constituição das Ciências Sociais em Saúde como campo de conhecimento e foi pioneira nos estudos sobre a profissão médica e o mercado de trabalho em saúde no Brasil. Faleceu em 1983. 
outro lado, acabar com a oposição entre atenção médica e saúde pública, que não conduz a nada. A atenção médica é parte da saúde pública e absolutamente necessária. Então o conceito de saúde coletiva surgiu para substituir uma terminologia que, na época, era insatisfatória. Ao recuperamos o conceito de saúde pública no sentido de saúde das populações, ele passa a ser sinônimo de saúde coletiva.

Alberto Pellegrini - O Juan César García teve importância na criação de dois cursos de Medicina Social, o da Uerj e o de Xochimilco, no México. Nosso movimento sanitário, em grande medida originado nos departamentos de medicina preventiva, no final dos anos 60 , e centrado no conceito de determinação social do processo saúde-doença, buscava uma identidade própria. Não nos satisfaziam nem a denominação de medicina social, por não a considerarmos uma especialidade da medicina, nem tampouco a de saúde pública, por considerarmos que esta adotava um enfoque muito tradicional, muito biológico que tinha como paradigma a Escola de Saúde Pública de São Paulo. Queríamos ter identidade própria, criar algo novo, daí o conceito de saúde coletiva. $\mathrm{Na}$ América Latina isso não ocorreu e os grupos mais progressistas continuaram adotando a denominação saúde pública.

\section{Como as contribuições deste debate promoviam um novo entendimento sobre as políticas de saúde e os recursos humanos em saúde?}

Alberto Pellegrini - Naquela época, por vários motivos, o acesso à literatura não era tão fácil. Juan César García preparava uma espécie de bibliografia selecionada, que enviava a grupos e pessoas de toda a América Latina. Líamos avidamente as cópias de artigos de Michel Foucault, [Michel] Pollack e outros autores que ele enviava com comentários. Nós, em Campinas, incluindo o Sérgio Arouca, recebíamos diretamente dele esse material e fazíamos seminários de discussão. Foi uma fase meio heróica de formação, ainda não muito estruturada. O Instituto de Medicina Social começava a introduzir esses textos em seu curso.

José Roberto Ferreira - Uma figura muito importante para a área de recursos humanos em saúde foi, sem dívida, Juan César García. Era argentino, formado em medicina e dedicado à pediatria. Depois fez um curso de ciências sociais e então foi para a Universidade de Harvard, quando foi indicado pela Millbank Foundation, organização que financiou o programa que ele veio 
desenvolver na Opas para realizar um estudo do ensino da medicina preventiva na América Latina. Este estudo contou com uma Comissão Diretora composta de professores ilustres da Inglaterra, EUA, Suécia, e outros países, e Juan César os convenceu de que para uma análise adequada do objeto do estudo, seria necessário primeiro uma abordagem mais geral de toda a formação médica na região, e isto, por sua vez, levava a idéia do mercado de trabalho, das demandas do estudante etc.

Depois de cinco anos, de 1965 a 1970, com o desenvolvimento do estudo em todos os países da América Latina, o resultado foi um livro: La educación médica en la América Latina. Paralelamente ele introduziu a medicina social como cadeira médica. [...] Naquela época só existiam médicos em matéria de profissionais de saúde. Os enfermeiros eram vistos como subalternos; a hegemonia médica era total.

IZABEL DOS SANTOS - A minha ligação com Juan César não foi através dos escritos dele sobre a escola médica. A minha ligação com Juan César e Miguel Márquez foi muito mais vinculada a uma luta política do que propriamente uma questão técnica de concepção de escola. Eles tinham vontade de me apoiar na luta política de uma sociedade mais justa. Eu nunca entrei, com eles, no mérito da discussão de uma escola médica. Eu sabia que eles tinham um sonho de que a América Latina fosse unida, de ter uma Universidade Latino-americana. Não sei nem por quê, mas eles tinham esse sonho.

José Paranaguá - O livro do Juan César García foi o primeiro estudo sobre educação médica feito com base nas ciências sociais. Com esse livro a educação médica passou a ser interpretada como um processo de inserção num determinado modo de produção, de valores e de bens na sociedade, por isso é uma referência-chave. A outra referência muito importante nessa época era a Cecília Donnangelo, como também o Eleutério Rodriguez Neto ${ }^{68}$, um dos grandes nomes da minha escola na área de Saúde Pública, aluno e discípulo da Cecília. [...]

A literatura era formada por poucas publicações, alguns documentos oficiais da Opas e os anais das reuniões da Abem, a Associação Brasileira de Educação Médica. Era o que estava disponível sobre o tema. Em 1972, quan-

${ }_{68}$ O sanitarista Eleutério Rodriguez Neto nasceu em Campinas, São Paulo, em 1946. Integrou a Comissão de Coordenação do Programa de Preparação Estratégica de Pessoal de Saúde (Ppreps), no início dos anos 1980 e foi secretário-geral do Ministério da Saúde ao final da mesma década. 
do houve a Reunião de Ministros de Saúde das Américas, o tema importante foi o de recursos humanos. Embora a reunião fosse para definir o Plano Decenal de Saúde Para as Américas, o eixo central deste foi o investimento em formação de pessoal, porque naquela época considerava-se uma grande defasagem entre disponibilidade de pessoal e necessidades de atendimento à saúde no conjunto de países das Américas. [...]

O Acordo Opas-Brasil em RH em saúde se autodefiniu, desde o início, como de cooperação técnica. Nos anos 1960/70 isto significava tentar superar a noção de assistência técnica. Qual a diferença entre as duas idéias e suas implicações para as relações interamericanas em saúde?

José Roberto Ferreira - A ação internacional começa com uma visão essencialmente filantrópica. O primeiro núcleo de ação internacional para controle de doenças sanitárias foi criado no Egito, em meados do século XIX. Depois a Fundação Rockefeller e o Instituto Pasteur começaram a oferecer ajuda aos países, sempre com caráter filantrópico, e vieram do Norte para o Sul. [...] Tratava-se, até então, de equilibrar as condições do comércio entre as duas situações. Tanto essas fundações quanto, depois, o governo americano traziam sempre soluções predefinidas, fórmulas a serem aplicadas nos países. Esse quadro evoluiu para a assistência técnica quando se criaram os organismos internacionais - a Opas em 1902 e a OMS [Organização Mundial da Saúde] em 1948. Em um ambiente multilateral, com a participação relativa dos países que constituem foros deliberativos nesses organismos, não havia mais uma imposição total, mas ainda assim as soluções continuavam a ser trazidas do mundo desenvolvido para o mundo em desenvolvimento.

Com o tempo e com o desenvolvimento de alguns países da América Latina, começou-se a dispor, no Sul, de gente capacitada, que passou então a assumir diretamente uma parte do processo de cooperação - e a Opas, nesse aspecto, talvez seja a mais progressista de todas. Essa capacitação permitiu que se desse uma certa horizontalidade, [...] e os próprios órgãos multilaterais começaram a buscar mecanismos de trabalho visando um maior compartilhamento no processo decisório e de implementação. Na América criaram-se então os centros multinacionais, entidades totalmente latino-americanas. Esses centros reuniam pessoal latino-americano atuando no próprio país, mas totalmente financiado por organismos internacionais também da América Latina. Mas um certo desequilíbrio se mantinha, pelo menos em ter- 
mos de conteúdos, e havia a crítica de que esses centros eram muito dispendiosos para os órgãos que os custeavam.

JosÉ PARANAGUÁ - Cooperação e assistência são termos presentes tanto no discurso quanto no ideário das Nações Unidas desde a sua criação, e fazem parte do processo de reorganização das relações entre os países, ocorrido depois da Segunda Guerra Mundial. De forma muito simplificada, podemos explicar a assistência técnica da seguinte forma: os países ricos, ou desenvolvidos, dão assistência técnica — que abrange conhecimento e financiamento a países pobres por meio de várias formas, entre elas os organismos internacionais, agências de cooperação ou de assistência técnica. Aí incluem-se a OMS, a Opas no caso das Américas, a FAO [Organização das Nações Unidas para a Alimentação e a Agricultura], a Unesco [Organização das Nações Unidas Para a Educação, a Ciência e a Cultura], o Pnud [Programa das Nações Unidas para o Desenvolvimento] e o Unicef [Fundo das Nações Unidas Para a Infância].

A diferenciação entre assistência e cooperação tem muito a ver com a experiência da Opas no Brasil e na América. E um dos principais mobilizadores de opinião política, de decisão para criação da Opas em 1902 foi o Brasil, com suas preocupações sobre o campo médico e a saúde pública. Desde o começo existiam pessoas no Brasil, na Venezuela e no Peru que tinham conhecimento de sua própria necessidade e sabiam como resolver seus problemas. [...] Então, a história da cooperação técnica da Opas tem essa diferença: ela já nasceu destinada a ser cooperação em vez de assistência. A atual diretora, por exemplo, vem falando em programa de cooperação técnica descentralizada. Eu acho que a maior experiência de cooperação técnica descentralizada foi aquela do acordo de cooperação Opas-Brasil na área de Recursos Humanos. [...]

José Roberto Ferreira - O termo cooperação surge no México em 1957, com Victor Urquidi ${ }^{69}$, um economista mexicano que dirigiu a Cepal. Ele foi um dos primeiros a falar em cooperação técnica com um sentido diferente da usual assistência técnica, admitindo que cooperar envolvia um intercâmbio entre as partes e se orientava a soluções ad-hoc e não modelos esteriotipados ajustáveis a qualquer contexto.

69 Victor L. Urquidi, economista mexicano, graduou-se na London School of Economics. Entre 1951 e 1958, compôs o secretariado da Comissão Econômica para a América Latina (Cepal). Presidiu o Colégio do México, tornando-se professor emérito desta instituição. Seu principal interesse intelectual residiu sobre o desenvolvimento econômico e o comércio. Nos anos 1990 dedicou-se às relações entre economia e o meio ambiente. 
No caso da Opas, embora a organização haja sido criada em 1902, inicialmente sua atividade restringiu-se à vigilância sanitária e, praticamente, uma cobertura mais ampla da área de saúde só veio a desenvolver-se depois do fim da segunda guerra mundial, na década de 50. A partir de então, o foco da cooperação, no campo específico do desenvolvimento de recursos humanos, centrou-se nas ciências básicas, tendo em vista que na América Latina não se havia desenvolvido a ciência médica, para o qual seria necessário reforçar a formação do pessoal nas ciências básicas melhorando o ensino básico. Isso durou talvez uns cinco ou dez anos.

Aí, entrou-se numa segunda fase, por influência do famoso seminário de Colorado Spring sobre ensino da medicina preventiva (1952), que foi depois reproduzido na América Latina em Viña del Mar, no Chile, e em Tehuacán, no México, em 55 e 56 respectivamente. A partir de então a Opas criou um programa de Seminários Viajeiros de Medicina Preventiva que levava professores selecionados a visitar outras escolas, já com alguma experiência nesse campo, nas quais se realizam debates sobre como conduzir o ensino de medicina preventiva. A Opas deve ter realizado uns cinco ou seis seminários desse tipo. A área de recursos humanos na Opas nasceu pequena mas cresceu rapidamente, porque o Fred Soper ${ }^{70}$ deu muita importância a ela.

No contexto de meados dos anos 1970, quais foram os elementos mais imediatos que possibilitaram a proposição e concretização de um programa de cooperação técnica especialmente voltado para os temas de RH em saúde no Brasil?

Carlyle Guerra de Macedo - O Brasil, naquele momento, estava na fase do milagre econômico e o Ministério da Saúde estava com muitos recursos financeiros. Um dos projetos do II Plano Nacional de Desenvolvimento, com financiamento definido, era o de recursos humanos para saúde; foi então firmado um acordo entre os Ministérios da Educação e da Saúde para formar um grupo com a participação da Opas como agência executora que elaborasse uma proposta para a área.

70 Fred Lowe Soper nasceu nos Estados Unidos, em 1893. Formado em medicina pela Universidade de Chicago, iniciou a sua carreira internacional nos anos 1920, pela Fundação Rockefeller, onde colaborou nas campanhas de saúde pública no Brasil e no Paraguai. Em 1947 torna-se diretor da Organização Pan-Americana da Saúde, cargo que permaneceu até 1959. Soper faleceu nos Estados Unidos em 1977. Ver: http://www.paho.org/spanish/dpi/100/directors00.htm (Acesso em 01.08.2006) 
Cesar Vieira - Entre 1973 e 1974 havia um quadro grande de progressistas no Ministério da Saúde. [...] Nessa época o Ministério da Saúde destinou uma verba grande para que a Fiocruz implementasse um projeto de recursos humanos na área da saúde, mas por alguma razão o projeto não saiu. $\mathrm{Na}$ mesma época fecharam o Ilpes, por causa do golpe no Chile, as pessoas foram retiradas de lá e o Carlyle veio ao Brasil para explorar oportunidades.

Houve algo no Brasil diferente dos demais países da América Latina. Tivemos diásporas brasileiras em 1964 e 1968, mas elas foram muito pequenas quando comparadas com a diáspora chilena, a argentina ou a de qualquer outro país da América Central. A maior parte dos brasileiros ficou no país, não houve uma grande migração. Os núcleos de Ribeirão Preto, Campinas, IMS [Instituto de Medicina Social, da Universidade do Estado do Rio de Janeiro], Ensp [Escola Nacional de Saúde Pública, da Fundação Oswaldo Cruz], Minas Gerais, Pernambuco permaneceram aqui, e nós conseguimos desenvolver idéias sobre descentralização e formação de auxiliar de saúde que foram depois incorporadas pelo Ppreps. [...]

Danilo Garcia - No Brasil, de repente... Eu tenho impressão que houve uma circunstância que talvez tenha sido decisiva. Eu não me lembro bem da história, de como essa idéia surgiu. Mas acho que dois fatores foram decisivos: um deles foi o [José Carlos] Seixas ${ }^{71}$ no Ministério; o segundo foram os brasileiros de Washington. Eu tenho a impressão que isto era um sonho do José Roberto. Eu me lembro do Zé Roberto com o Seixas, ... eles botaram a bola em movimento.

José Roberto Ferreira - Em geral, os acordos da Opas eram elaborados em termos neutros que afirmavam - é claro - as boas intenções de um trabalho conjunto. Em 1973, assinou-se, com o Brasil, um acordo de cooperação que abrangia toda uma área de atuação, sem especificar ações. Já o de 1975 foi um programa firmado com base em um projeto que se elaborou previamente. São duas coisas inteiramente diferentes, mas um não invalida o outro. O acordo de 1973 continuou existindo; era ele que dava cobertura à permanência, no Brasil, do Carlos Vidal, consultor de recursos humanos, sob um convênio geral. $\mathrm{O}$ outro era um programa específico, que foi inclusive

71 José Carlos Seixas nasceu em Marília, SP, em 1937. Graduou-se médico, em 1963, pela Universidade de São Paulo (USP) e obteve o título de doutor em Saúde Pública, em 1972, também pela USP. Foi Secretário Geral do Ministério da Saúde durante o governo do Presidente Ernesto Geisel. Atualmente é assessor técnico da Secretaria de Estado da Saúde de São Paulo. 
desenhado por esse consultor, mas que ganhou autonomia e para o qual se nomeou um grupo brasileiro para coordenar. [...]

Carlyle Guerra de Macedo - Para a Opas, o primeiro item da agenda do acordo foi estruturar um órgão no Ministério da Saúde que se responsabilizasse pela coordenação das ações e fosse replicado nos estados. Esse órgão iria coordenar as atividades realizadas pelos ministérios e secretarias envolvidas, no âmbito do acordo: formação, educação continuada, etc. Esta era a primeira grande meta - criar o centro de atividades da cooperação - e conseguimos realizá-la. Depois era fazer com que a cooperação funcionasse, o que já foi mais difícil, porque exigia que os órgãos responsáveis tivessem capacidade operacional para exercer suas funções, e nem sempre se conseguiu isso. E acho que o quadro não mudou. Havia outras áreas importantes, como o apoio ao ensino e a integração docente-assistencial, mas o núcleo da cooperação continuava sendo este: assegurar uma estrutura institucional que fosse capaz de operar a realização das atividades de recursos humanos para a saúde no país.

José Paranaguá - O ano de 1975, como marco inicial da cooperação técnica em recursos humanos da Opas no Brasil, é um pouco arbitrário. Muitas vezes os acordos são assinados, mas leva tempo para que os processos se materializem. Na verdade o acordo só teve vigência, em termos operacionais, com a liberação de financiamento para os projetos, a partir de 1976. O período de 1973 e 1974 foi de negociação política, de elaboração das propostas, de definição sobre quem, da organização, viria para o Brasil trabalhar com o projeto. O consultor de recursos humanos da Opas aqui era o doutor Carlos Vidal, que tinha voltado para Washington, e creio que levou um tempo também a decisão de quem viria participar do programa de cooperação. A escolha acabou recaindo sobre o Carlyle Macedo. Então, embora a base legal e institucional do projeto existisse anteriormente, eu adoto 1975 como marco inicial da cooperação técnica da Opas na área de recursos humanos em saúde no Brasil porque esse foi o ano em que ocorreu a designação do consultor da Opas para trabalhar no projeto. Carlyle veio para o Brasil e, ainda 1975, reuniram-se os primeiros integrantes desse projeto, para elaborar o plano de ação do projeto, que foi batizado com o nome de Ppreps. [...] 


\section{Como se deu o processo de composição da equipe do Ppreps, do núcleo central da cooperação?}

José Roberto Ferreira - Desde o início os brasileiros tiveram preponderância na equipe do Ppreps; tinha mais brasileiro do que qualquer outra nacionalidade. E a idéia era criar um programa que cobrisse totalmente o Brasil. Já havia projetos isolados em algumas universidades, mas pretendia-se criar um programa que cobrisse totalmente o país. [...]. Carlos Vidal, que era professor de Medicina Preventiva na Universidade Peruana Cayetano Heredia, em Lima, veio participar do projeto. E Ernani Braga, que tinha retornado recentemente de Genebra, também se incorporou a esse grupo.

Então começamos a pensar o que se poderia oferecer ao governo como solução integral de desenvolvimento de recursos humanos em saúde. Na época o Ipea [Instituto de Pesquisa Econômica Aplicada] tinha uma área de recursos humanos, e viu-se nisso uma oportunidade de se fazer um projeto grande. Então começou-se a trabalhar. Eu tive que ir ao Ceará durante uns 15 dias e quando voltei o projeto estava praticamente pronto. Tinha um orçamento milionário que, obviamente, todos achávamos que não seria aprovado. Mas em todo caso entregamos o projeto ao presidente da Fiocruz. Voltei para Washington e o Carlos Vidal prosseguiu com as atividades dele. $\mathrm{Na}$ época o Paulo de Almeida Machado era ministro, o secretário era o José Carlos Seixas e João Yunes ${ }^{72}$, o chefe de gabinete. Depois de seis ou oito meses, Vidal me disse: "Aquele projeto que nós apresentamos foi aprovado, aparentemente na íntegra." E me contou que tinha conversado com o doutor Oswaldo Costa, então diretor da Escola Nacional de Saúde Pública, e ele definitivamente não aceitava o projeto. Pela proposta inicial, uma vez aprovado, o projeto seria coordenado pela Ensp para o Brasil inteiro. Naquela época o orçamento do projeto era várias vezes maior que o da Escola Nacional de Saúde Pública, que ainda era pequena - ela cresceu depois, com Ernani Braga. O diretor da

72 João Yunes foi médico pela Universidade de São Paulo e mestre em Saúde Pública pela Universidade de Michigan. Doutorou-se em medicina pela Faculdade de Medicina da USP, onde chefiou o Departamento de Pediatria Preventiva e Social. Presidiu o Centro Brasileiro de Análise e Planejamento (Cebrap). Foi Secretário Nacional de Programas Especiais de Saúde, do Ministério da Saúde. Entre 1975 e 1977, foi responsável pela organização de duas Conferências Nacionais de Saúde, que não eram realizadas a quase uma década. Ainda em 1975, obteve o título de Livre Docente em Pediatria Preventiva e Social pela FMUSP. Assumiu em 1983 o cargo de Secretário de Estado da Saúde de São Paulo. Foi representante da Opas em Cuba (1987-1989). Em 1998 assumiu a Secretaria de Políticas de Saúde do Ministério da Saúde. Em 2001 foi eleito Diretor da Faculdade de Saúde Pública da Universidade de São Paulo. Faleceu em 2002. Ver: www.abrasco.org.br/ Boletins/bol86/Yunes.htm (Acesso em 31.07.2006) 
Ensp argumentou que não tinha a menor condição de assumir aquilo, que era uma responsabilidade muito grande, e criou-se um impasse. Vim então ao Brasil e insistimos outra vez com o Oswaldo, mas não houve meios de ele concordar. Fomos então conversar com o [José Carlos] Seixas, com quem tínhamos muito boas relações, e ele disse: "Não tem problema. Vamos fazer do projeto um projeto nacional, com base na própria organização e subordinado ao ministério." Era um trust fund: o dinheiro brasileiro seria transferido à Opas em moeda nacional, a organização o absorvia na sua contabilidade, transformando-o em dólar, e contratava o pessoal do projeto, pagando em dólar como funcionários internacionais normais. Isso era inédito na Opas também, porque naquela época não se contratavam nacionais.

Tínhamos então um projeto em mãos e precisávamos resolver como implementá-lo. Com o Seixas nós acordamos um grande seminário, com um determinado número de convidados, com os quais discutiríamos não só como levar o projeto à prática, mas também a seleção daqueles que o administrariam. A reunião foi realizada em Brasília, no edifício do INAN, o Instituto Nacional de Alimentação e Nutrição, cujo diretor era Bertoldo Kruse ${ }^{73}$, de Pernambuco. Durou três dias, com 30 a 40 participantes: o staff do ministério, Carlyle - que já era funcionário da Opas trabalhando no Cendes -, César Vieira, Izabel dos Santos, Francisco Salazar, Yunes, Seixas, pessoas da área da saúde da Bahia e de São Paulo e várias outras. Os quatro primeiros nomes indicados foram além do Carlyle, como diretor e coordenador do projeto ele seria transferido do Chile para cá - , Cesar Vieira, Izabel dos Santos, Francisco Salazar e Danilo Garcia [...] todos contratados como funcionários internacionais da Opas, com salário em dólar. As pessoas eram nomeadas pela organização, mas seus nomes tinham de ser aprovados pelos ministérios porque a verba do projeto era brasileira. Mas isso permitiu pagar salários altamente competitivos e selecionar os melhores; esta era a idéia por trás do projeto.

Carlyle Guerra de Macedo - Criou-se o projeto, tinha-se dinheiro, mas não havia quem fizesse o trabalho. Não era por falta de dinheiro — nem sempre o problema é este —, mas sim por falta de estrutura de pessoal. [...] O Sergio Arouca era um dos candidatos a coordenador da equipe; todo mundo

73 Bertoldo Kruse Grande de Arruda é médico pela Faculdade de Medicina da Universidade do Recife (1948) e doutor em medicina pela Universidade Federal de Pernambuco (1974). Foi presidente do Instituto Nacional de Alimentação e Nutrição (Inan). Atualmente, Bertoldo Kruse é pesquisador da Universidade Federal do Pernambuco e vice-presidente do Instituto Materno Infantil de Pernambuco. 
o queria, mas ele não aceitou vir para Brasília. [...] Então me chamaram para organizar esse grupo. Na época o Ministério da Saúde era muito débil, nem se compara ao que é hoje. No MEC [Ministério da Educação e Cultura] também a realidade era outra. Não havia realmente quem trabalhasse no projeto, e para implementá-lo era preciso formar uma equipe. Isso levou dois anos.

Não foi muito difícil a formação do grupo, porque a liberdade era relativamente restrita. Era preciso ter pessoas dos ministérios, e eu representava a Opas. Não houve pressão da Organização para selecionar especificamente alguém, mas tínhamos de aceitar quem os ministérios indicassem. Veio uma pessoa de cada um deles, e recrutamos mais umas quatro ou cinco, o que não foi difícil. O grupo começou a trabalhar, discutir e visitar os estados para elaborar o plano de ação.

José Paranaguá - A primeira equipe técnica do acordo de cooperação foi constituída pelo Carlyle, consultor de recursos humanos da Organização Pan-Americana da Saúde, que era o coordenador do grupo técnico. Ele estava em missão no Chile quando foi convidado para assumir esse cargo no Brasil. A equipe foi se formando ao longo do ano de 1975, e a partir de meados de 1976 estava praticamente completa. Era composta pelo Cesar Vieira, oriundo da área de planejamento da Secretaria de Saúde de Minas Gerais, Izabel dos Santos, que era professora da Universidade Federal de Pernambuco, Francisco Salazar $^{74}$, um consultor da Opas de nacionalidade chilena, e Danilo Prado Garcia, um cirurgião muito bem-sucedido de São Paulo que resolveu ingressar na saúde pública, nesse campo de recursos humanos. Foi basicamente esse pequeno grupo que funcionou como a equipe técnica do Acordo. O secretáriogeral do Ministério da Saúde era o José Carlos Seixas, e ele também fazia parte da coordenação do programa.

IZABEL Dos SANTOS - Na época que eu estava com Roberto Nunes ${ }^{75}$, desenvolvendo uma experiência de organização de serviço, muito charmosa e

\footnotetext{
${ }_{74}$ Francisco Salazar, chileno, coordenou o Curso de Administração de Sistemas de Saúde da Escola Interamericana de Administração Pública -FGV, fornecido em parceria com o MS a OPAS. Ver: Noronha et al., 1977: 443.

75 Roberto Moreira Nunes da Silva graduou-se em medicina pela Universidade Federal de Pernambuco (UFPE), em 1963, especializou-se pela mesma universidade em 1984. Chefiou o Departamento Estadual da Criança (1971-1976), também em Pernambuco. Em 1975 ingressou na Universidade de Pernambuco (UPE), onde desenvolveu atividades docentes e de pesquisa em áreas como pediatria, puericultura, avaliação do ensino médico e de serviços. Em 1983 ingressou na UFPE, dedicando-se ao ensino de Pediatria na Faculdade de Ciências Médicas. Ver Currículo Lattes, em http://buscatextual.cnpq.br/buscatextual/index.jsp
} 
interessante no bairro da Encruzilhada, João Yunes ia muito a Recife. Foi lá que ele me conheceu, me viu atuando, brigando, aprontando e me convidou para trabalhar em Brasília, integrando um grupo especial que estava sendo organizado para cumprir o acordo da Opas com o governo brasileiro. [...]

Eu já tinha feito alguns trabalhos para a Opas. Eu já tinha sido membro de comitês de escolha de livro-texto; já tinha sido convidada, na época da Aliança para o Progresso, para fazer parte de um grupo para discussão sobre políticas públicas. Nesse período fiz algumas viagens para vários países da América Latina. Essa experiência foi hilária! Eu não conseguia compreender como se queria fazer uma política de saúde que coubesse da Guatemala ao México. Só se fosse mágica! [...] Eu vim trabalhar nesse programa porque vislumbrei uma forma de fazer caminhar o meu trabalho no Brasil. O meu compromisso era criar para atender às necessidades do meu país.

Cesar Vieira - Depois de gerada a idéia, acho que o primeiro chamado para integrar a equipe foi o Carlyle; depois, a Izabel dos Santos, que esteve no Sesp [Serviço Especial de Saúde Pública]. Depois chamaram o Francisco Salazar, que estava trabalhando no Rio de Janeiro, na área de administração pública. [...] Mas precisavam de alguém da área docente médica, e Danilo Prado Garcia, professor de Cirurgia da USP, foi incorporado ao grupo. Danilo tinha ido a Washington, conhecera José Romero Teruel ${ }^{76}$ e Juan César García, na Opas, soube por eles do projeto no Brasil, voltou, entrevistou-se e entrou na equipe. Ficava faltando um último moicano, alguém da área de planejamento. O candidato natural era o [Sérgio] Arouca, mas ele, por alguma razão, não aceitou o convite. Perguntaram então pelo Eugênio Vilaça Mendes ${ }^{77}$, que tinha

76 Jose Romero Teruel integrava a equipe do Departamento de Recursos Humanos da Opas, em Washington. Na primeira metade dos anos 1970 foi colaborador principal da Opas em um projeto de estudo da mortalidade infantil na região de Ribeirão Preto, São Paulo. Na segunda metade dos anos 1980 e início dos 90 dedicou-se à avaliação de sistemas e programas prioritários de saúde. Foi diretor da Divisão de Saúde e Desenvolvimento Humano e Assessor Especial para Saúde Internacional da OPAS, em Washington.

77 Eugênio Vilaça Mendes é odontólogo, graduado pela Universidade Federal de Minas Gerais (UFMG). Doutorou-se em Cirurgia Bucal em 1968, também pela UFMG. Em 1969 especializou-se em Planejamento de Sistemas de Saúde, pela Escola Nacional de Saúde Pública. É mestre em Administração pela UFMG, título obtido em 1975. Na primeira metade da década de 1970 foi Diretor Técnico Instituto de Preparo e Desenvolvimento da Assistência Sanitária Rural, atuando nos primeiros anos do Projeto Montes Claros. Desenvolveu atividades docentes na Faculdade de Medicina do Norte de Minas, na Fundação Getúlio Vargas, na Pontifícia Universidade Católica de Minas Gerais e na Universidade Federal de MG. Desde 1966 vem atuando junto às áreas de planejamento da Secretaria de Estado da Saúde de Minas Gerais. Na Representação da Opas no Brasil foi Coordenador da Área de Sistemas e Serviços de Saúde, assim como de Infra-estrutura de Sistemas de Saúde. É professor da Escola de Saúde Pública do Ceará e consultor em vários organismos e instituições. Ver Currículo Lattes em: http://buscatextual.cnpq.br/buscatextual/ index.jsp (Acesso em 01.08.2006). 
feito o curso de planejamento do Cendes-OPS. Ele era importante em Minas Gerais, era da Secretaria de Saúde, foi um dos precursores de Montes Claros e foi responsável pela revirada da odontologia social naquele estado. Foram falar com ele, mas ele não topou.

Eu tinha conhecido o Carlyle um ano antes, em uma reunião na casa do Eugênio Vilaça Mendes, em Belo Horizonte. Na ocasião, o Carlyle queria saber da possibilidade de fazer o centro de pesquisa em Minas Gerais, já que tínhamos experiência de planejamento em saúde, tínhamos Montes Claros, estávamos trabalhando muito com o Ilpes, na Secretaria de Planejamento, na Fundação João Pinheiro, estávamos envolvidos na criação das Secretarias de Saúde do Amapá, de Rondônia, Roraima e Acre, que estavam sendo transformados em estados. Mas naquele momento havia um racha na Secretaria de Saúde e na Universidade e desaconselhamos a ida do Carlyle para Minas Gerais. Logo depois houve uma mudança na secretaria e o pessoal que era segundo escalão assumiu a direção. Então, um ano depois, o Carlyle me chamou para participar do Ppreps, eu me fascinei com o projeto e, apesar de estar em um processo muito bacana na secretaria, resolvi aceitar o convite. Eu fui o último a ser incluído na equipe. [...]

A Izabel [...] mexia mais com a parte de formação de pessoal auxiliar e ensino profissionalizante. Danilo era responsável pela área de integração docente-assistencial. Salazar atuava em informação e apoio à administração de saúde. Eu trabalhava com planejamento de saúde.

José Paranaguá de Santana - Eu entrei [em 1979] por indicação da Sesu [Secretaria de Educação Superior do MEC] Mais precisamente do doutor Carlos Marcílio de [Souza]. [...] que foi o Chefe da Assessoria de Educação Médica do MEC [...] Os outros dois candidatos do MEC eram uma técnica de educação, a Regina Coeli Nogueira, que foi mobilizada porque a Izabel andava atrás de uma pessoa envolvida com educação técnica, já era dentro do plano da Izabel de envolver gente com a proposta de formação de nível médio em saúde...[...]; o Francisco Lopes, que era um técnico de carreira do Ministério da Educação, que, na época, era assessor do secretário-geral, e foi indicado pelo secretário para compor essa equipe técnica. E fazia o perfil, porque eu era médico, Regina era educadora e o Francisco era administrador. Então, a idéia era que a gente partisse das linhas de trabalho do MEC, desenvolvimento institucional, de recursos humanos, de plano de carreira, que era a área que o Chico Lopes trabalhava; desenvolvimento da educação técnica, que 
era a área da Regina, e essa parte de integração docente-assistencial, de pósgraduação em saúde coletiva, que era eu que trabalhava.

$\mathrm{O}$ [Alberto] Pellegrini entrou na época que eu entrei também, com uma diferença: ele já vinha acompanhando esse projeto como assessor, pelo Ministério da Previdência.

Alberto Pellegrini - Quando termina o Piass [Programa de Interiorização das Ações de Saúde e Saneamento], o grupo que constituía sua secretaria técnica se dispersa. Aparece então para mim a oportunidade de participar da Secretaria de Serviços Médicos da Previdência Social (SSM), que estava sendo reestruturada, sob a liderança de Marlow Kwitko ${ }^{78}$, e com a participação do grupo do Ppreps: Cesar Vieira, Carlyle e outros. Eles tiveram conhecimento da minha existência e me indicaram para integrar a SSM. O Serviço Nacional de Informações [SNI], vetou meu nome, mas o secretário geral do Ministério da Previdência assumiu a responsabilidade por minha indicação e eu pude ficar. Mas, não foi por muito tempo. Não terminou o ano de 79, o Ministério da Saúde encomenda para a OPS, para o Acordo da OPS, liderado pelo Carlyle, a coordenação da elaboração do projeto do Prev-Saúde. O Mozart de Abreu e Lima, que era o secretário-geral do Ministério da Saúde, convidou-me para trabalhar com ele no Ministério, vinculado a esse projeto, e como era obrigatório, submeteu meu nome ao SNI. O SNI do Ministério da Saúde não só não permitiu que eu fosse contratado para o Ministério da Saúde, como entrou em contato com o SNI do Ministério da Previdência para que eu fosse demitido ${ }^{79}$. Justamente nessa mesma época a Previdência Social passou a integrar o acordo da Opas, o Ppreps, juntando-se ao Ministério da Saúde e MEC. Fui então indicado pelo Ministério da Previdência para integrar-me ao grupo do Acordo, onde pude continuar trabalhando no Prev-Saúde.

Roberto Passos Nogueira - Quando eu fui do Rio de Janeiro para Brasília, a Nina Pereira Nunes ${ }^{80}$ fez uma carta de apresentação minha para o

\footnotetext{
78 Marlow Kwitko é médico pela Faculdade de Medicina da Universidade Federal do Rio Grande do Sul (1968). Especializou-se em Saúde Pública pela Universidade de São Paulo em 1970, e em Epidemiologia e Controle de Tuberculose pelo Instituto Nacional de Tuberculosis José Ignácio Baldo, da Venezuela, em 1974. Concluiu o mestrado em Saúde Pública na Universidade de São Paulo (1973). Atualmente é da Secretaria da Saúde e do Meio Ambiente do Rio Grande do Sul, Representação Institucional do Conselho Municipal de Saúde de Porto Alegre, Coordenador do Departamento de Medicina Social da Pontifícia Universidade Católica do Rio Grande do Sul.

79 O SNI, à época, dispunha de escritórios em cada um dos ministérios.

80 Nina Pereira Nunes foi médica. Junto com Piquet Carneiro, Hésio Cordeiro e outros, no início dos anos 1970, fundou o primeiro programa de mestrado em medicina social da América Latina, o Instituto de Medicina Social da Uerj.
} 
Carlyle. Então, quando eu saio daqui, no começo de 1977, eu já tinha uma carta de apresentação. Mas o Carlyle não tinha ainda como me colocar lá. Eu não sei..., acho que ele fez uma avaliação de que eu precisava um pouco mais de tempo. Então, ele me indicou para uma assessoria no Ministério da Saúde, onde estava se criando um grupo, um grupo muito pequeno, de três ou quatro pessoas, pra trabalhar com recursos humanos. Em 1979, eu saí do Ministério da Saúde e fui para o Ministério do Interior, onde fiz um estudo das condições sanitárias e assistenciais da Bacia do Alto Paraguai.

Isso foi em 1979. Em 1980, há uma reprogramação, uma reestruturação do Ppreps. [...] Eu não sei quando é que entra o Ministério da Previdência, mas, no final, se conformou um convênio tripartite: Ministério da Saúde, Ministério da Previdência, Ministério da Educação com a Opas. Bem, então, quando se formou, esse, é, esse grupo, o Carlyle me convidou, no começo de 1980, para compor o GAP, Grupo de Assessor Principal.

O Programa de Preparação Estratégica de Pessoal em Saúde, Ppreps, foi o ponto de partida da cooperação técnica, como foram seus momentos iniciais?

José Paranaguá - No Brasil tudo começou com o Acordo Para um Programa Geral de Desenvolvimento de Recursos Humanos Para a Saúde no Brasil, que previa a definição de atividades. $\mathrm{O}$ documento desse acordo, que é o programa de trabalho, já nasceu com o nome Ppreps, Programa de Preparação Estratégica de Pessoal em Saúde no Brasil. O acordo inicial vigorou até 1978. Havia nele uma certa dose de megalomania - como todo projeto - e algumas metas não foram realizadas até o seu prazo final. Uma delas era implantar dez regiões docente-assistenciais, outra era o treinamento de cento e tantos mil auxiliares - foram treinados cerca de oitenta mil - e outra ainda era um projeto de desenvolvimento institucional das secretarias, que andou muito pouco. Por outro lado, o programa teve outros resultados: reforçou as instâncias que vinham lutando pela implantação da reforma sanitária, [...] movimentos em que o Ppreps esteve envolvido. [...] A primeira fase do acordo de cooperação técnica teve, muito mais do que metas quantitativas do projeto, um efeito de fermentação, de turbinar motivações, de valorizar uma área técnica e mobilizar atores em situações concretas e específicas do próprio país. $\mathrm{E}$ isso não foi só uma ação da Opas, até porque esse projeto era totalmente nacional, com muito pouca influência de escritórios da organização fora do Brasil. 
Carlyle Guerra de Macedo - Lembro-me um pouco do que levantamos sobre as condições de recursos humanos em saúde na época. Em primeiro lugar, havia o problema da inadequação entre a disponibilidade de recursos humanos e as necessidades da população. A constatação valia não só para médicos e dentistas, mas para todas as categorias. Um dos componentes fundamentais do Ppreps foi a formação de pessoal de nível médio, porque esta era a categoria em que tínhamos observado uma grande disfuncionalidade. A maior parte do pessoal de enfermagem, por exemplo, era atendente sem nenhuma formação ou preparo para atuar tanto nos hospitais como nos programas de saúde publica. E nós pensamos, na época, que esta talvez fosse a área mais fácil de mudar. Depois havia a situação das condições de emprego, muito heterogêneas. Eu me refiro ao setor público, dos municípios ao ministério - não estou nem falando do setor privado. Outro problema que me lembro bem era o da formação médica de nível de graduação. As escolas de medicina estavam muito afastadas da realidade social do país, e uma das propostas sobre as quais muito se insistiu, na época, foi a da integração docenteassistencial, como estratégia axial para as mudanças necessárias. [...]

Como quase todos as iniciativas de saúde no Brasil, o Ppreps foi conceitualmente importante, inclusive em termos continentais. Nisso nosso país tem uma originalidade em comparação com a maioria dos países da região e do mundo: geralmente nós criamos as coisas aqui. O SUS [Sistema Único de Saúde], por exemplo, é uma proposta de reforma de saúde tipicamente brasileira. Não há similar, e nenhum contrabando ideológico, pelo menos significativo, está embutido nela. Respeitadas as diferentes dimensões porque o SUS vem de um movimento sanitário, é algo muito mais amplo que faz parte da redemocratização do país —, o Ppreps é também uma criação nacional. Lógico, houve participação da sede da Opas em Washington, e o José Roberto Ferreira participou de muitas discussões. Mas o Banco Mundial não teve nada, direta ou indiretamente, a ver com o Ppreps, nem o Banco Interamericano ou a OMS em Genebra. Washington sim, sobretudo através de José Roberto e seu grupo. E houve participação de muita gente nossa. O grupo específico do programa teve o cuidado de ouvir secretarias de saúde, ministérios, escolas; ouviu-se muito. E dessa capacidade de ouvir saiu a proposta, que era mesmo um pouco utópica. Nós do grupo sabíamos que ela não seria realizada, mas queríamos lançar a idéia, esperávamos que as condições políticas do Brasil mudassem e que uma formulação dessa magnitude seria adequada aos novos tempos que estavam por vir. 
José Roberto Ferreira - A idéia de levar o planejamento de recursos humanos aos estados começou muito mais forte na área de integração docente-assistencial, que eu acho que depois se enfraqueceu. Mas o grande benefício do Ppreps ao Brasil foi levar a área de recursos humanos para o Ministério da Saúde. No fundo, essa experiência foi inspirada em Cuba, o único país que tinha, então, recursos humanos no Ministério da Saúde e não no Ministério da Educação. E aqui no Brasil era muito mais lógico que o Ministério da Saúde assumisse, diante da situação do Ministério da Educação. A Saúde afirmava: "Precisamos defender a atenção básica"; o Ministério da Educação respondia: "Sim, com programas de residência e formação de especialistas." Era uma oposição total. As marcas eram estas: a ênfase da educação era a especialização universitária, a medicina acadêmica; a ênfase de saúde era atenção básica. Virar o pêndulo para o lado da saúde foi uma obra fantástica do Ppreps, e a carga de trabalho foi muito grande. [...]

Eu diria que nós, da Opas, [...] queríamos levar a gestão em recursos humanos para a área da saúde, e sem dúvida alguma trouxemos a experiência de Cuba e Nicarágua. Mas o papel do Ppreps nessa tarefa foi original. A sua equipe teve condições, capacidade e interesse de abordar uma área que não sabíamos como manejar. Em Washington não tínhamos ninguém trabalhando com gestão; o primeiro grupo que entrou nessa linha foi o Ppreps.

Danilo Garcia - Bom, em princípio, havia um contato via Ministério da Saúde, que acionava as Secretarias de Saúde, e a partir das Secretarias de Saúde, eventualmente, as universidades, as faculdades com as suas áreas específicas e se ia ao estado fazer um diagnóstico. Não, não era propriamente um diagnóstico da condição de saúde da população, um diagnóstico do sistema de saúde, como se dizia, "o sistema de saúde". Se fazia um diagnóstico, se encontravam os problemas, montavam-se estratégias.

Neste contexto como se desenvolviam as relações entre Opas-Washington e o grupo técnico da cooperação no Brasil?

Alberto Pellegrini - Tínhamos muito contato com o pessoal de recursos humanos da Opas, em Washington, mas mantendo uma grande autonomia. A Opas era uma Organização bastante conservadora, mas havia 'ilhas inovadoras' e entre elas o programa de recursos humanos, onde estavam Juan César García, Miguel Márquez, Carlos Vidal e outras pessoas muito afinadas com grupos do Brasil como os do Peses [Programa de Estudos Socioeconômicos em Saúde, da 
Ensp] e do Projeto Montes Claros. Esse vínculo, não só conosco, mas com outros grupos na América Latina, constituía também uma rede de sobrevivência, às vezes até em sentido literal. Pessoas perseguidas por ditaduras sobreviveram graças ao vínculo com esse grupo, porque podiam ser recebidas e contratadas em outro país. O Juan César teve um papel muito importante nessa rede. [...]

O Carlyle tinha uma autonomia muito grande e muitos recursos próprios. Nosso grupo era quase um enclave dentro da Organização. Tínhamos relações pessoais e de trabalho com as demais pessoas da representação brasileira da Opas, mas participávamos amplamente de tudo o que acontecia na área da saúde, ao contrário dos demais consultores da Opas que tinham uma inserção mais especializada. Por exemplo, como membros do acordo de cooperação, nós participamos diretamente da organização da Conferência Nacional de Saúde de 1986, com o Sérgio Arouca e todo aquele movimento, enquanto os demais consultores da representação da Opas praticamente não tinham informação de que haveria uma conferência nacional de saúde.

Danilo Garcia - A nossa área aqui era diretamente vinculada ao José Roberto Ferreira, em Washington. E eu até diria o seguinte, não sei bem se havia algum mecanismo que formalizava a relação de um Carlyle, que era o coordenador do Ppreps, com o José Roberto. Mas havia muito contato, e o Zé Roberto vinha com certa freqüência ao Brasil e as conversas eram algumas formais, mas, às vezes informais. O Carlyle tinha, porém, muito prestígio. Ele veio do Chile cioso da condição dele na Opas. Porque ele era antigo na Opas, nós éramos pequeninos, calouros. Mas ele era antigo [...] Então, o Carlyle tinha uma autonomia aqui muito grande.

José Roberto Ferreira - Na realidade havia projetos e orientações que o Ppreps absorvia e aplicava no Brasil, e havia os que não eram adotados, porque o ministério os considerava inadequados ou simplesmente porque os membros do Ppreps não se identificavam com eles. Por exemplo, um programa que começou no período do Héctor Acuña, em 1978, e se desenvolveu até Carlyle foi o que chamamos, na época, de análise prospectiva da educação médica. Ele foi desenvolvido totalmente pelo nível central da Opas e aplicado em quase todos os países da América Latina, mas não aqui; o grupo brasileiro simplesmente rechaçou a idéia na ocasião. [...] O Brasil tinha essa característica. De fato, a equipe que estava à frente do programa era muito mais relacionada à política local e aos brasileiros do que nós, que estávamos em Washington, e por isso funcionava um pouco mais autonomamente. 
Um bom exemplo é o Cadrhu [Curso de Aperfeiçoamento em Desenvolvimento de Recursos Humanos em Saúde], na década de 80. Ele foi gerado essencialmente no Brasil, pelo grupo do Paranaguá. A participação da Opas foi muito pequena. Lembro-me que estive presente no encerramento de um dos cursos, acho que em Brasília, e nada mais. O curso foi essencialmente do Ppreps. [...]

Eu, de Washington, não me envolvia, até porque o pessoal local encontrava as portas abertas. Certamente em alguns estados as relações eram melhores do que em outros. No Piauí, por exemplo, tinha também um pessoal muito bom, mas era pura decisão local. O GTC [Grupo Técnico Central] sempre foi o órgão central, as comissões nos estados funcionavam mais na integração com a Secretaria de Saúde ou a universidade local.

Cesar Vieira - Da mesma maneira que havia uma certa tensão entre Washington e Santiago na área de planejamento, com o Cendes-OPS, houve também tensão na área de recursos humanos entre Washington e Brasil, sobretudo devido a posições ideológicas, mas em parte porque o diretor da Opas Hector Acuña, que começou seu mandato em 1975, era muito menos liberal do que o anterior, [Abraham] Horwitz ${ }^{81}$.

O Cendes ganhou autonomia, entrava nos países, começou a formar centenas de pessoas, e tenho a impressão de que isso também gerou ciúmes. De repente, a metodologia Cendes-OPS começou a ficar muito mais visível do que a atuação da Opas em planejamento. Mas em vez de fazer uma aliança produtiva, frutífera, mutuamente satisfatória entre o cérebro e a base, houve uma tensão. Conosco a tensão era menor, mas a área era muito dividida em Washington. [...]

Havia tensões, mas também havia diálogo. Nós aqui estávamos muito perto da reforma sanitária que estava começando e tínhamos que dar respostas, não podíamos ignorar isso. Estávamos muito inseridos, enquanto que o pessoal de Washington, normalmente, ficava mais distante, mais no âmbito dos ministérios, dos governos. [...] Quando o Carlyle candidatou-se à direção da Opas, a discrepância ficou mais séria, mas depois de eleito isso foi superado.

$\overline{81}$ Abraham Horwitz, médico chileno, formado pela Universidade do Chile, em 1936, concluiu mestrado em Saúde Pública na Universidade John Hopkins, em 1944, como bolsista de Fundação Rockefeller. Ingressou na Opas em 1950, onde desempenhou diversos cargos. Foi eleito seu Diretor em 1958, sendo o primeiro latino-americano a ocupar o cargo. Permaneceu na direção da Organização até 1975, quando substituído por Héctor Acuña. Ver: http://www.paho.org/spanish/ dpi/100/directors05.htm (Acesso em 02.08.2006) 
Como foi a relação da equipe técnica central da cooperação com os ministérios signatários do Acordo?

José Paranaguá - Qualificávamos nossa situação de 'anfíbia'. Nós éramos contratados pela Opas, mas nossos contratos eram financiados pelos ministérios. Por exemplo, eu fui contratado pela Opas durante quase três anos — entrei em 1979 e meu cargo foi extinto em 1983 —, mas o financiamento desse contrato esteve a cargo do Ministério da Educação. Eu trabalhava, prioritariamente, em projetos de interesse desse ministério, mas participava de todos os outros projetos. Não fazíamos distinção, não tinha diferença. Quando o Ministério da Saúde precisava de alguém, em algum estado, para ajudar a resolver um problema, qualquer um de nós ia.

Roberto Nogueira - Havia uma divisão de trabalho. A Opas se ocupava mais com a cooperação nos estados. O Ministério da Saúde tinha uma assessoria de recursos humanos, mais voltada para as suas necessidades internas e, simultaneamente, tinha programas que financiavam cursos específicos para capacitação nos estados, sobre tuberculose, hanseníase, saúde materno-infantil etc. A assessoria era estratégica para o ministério, porém não tinha uma perspectiva de cooperação técnica. Então, até onde eu sei, isso foi objeto do acordo entre a Opas e o ministério, que não tinha capacidade de dar conta da tarefa. A Opas assumiu-a e atuava diretamente nos estados e nas universidades. No início da década de 1980, com a chegada da Lia Fanuck ${ }^{82}$ há uma mudança, e o GAP teve que dividir as funções de cooperação com o próprio ministério. [...]

O GAP funcionava com total autonomia em relação aos ministérios. Havia o convênio e os ministérios faziam termos aditivos a ele. Eventualmente indicavam algumas pessoas, mas elas passavam a fazer parte do grupo da Opas. Não era um grupo à parte identificado com o ministério, um comitê que mantém a vinculação institucional de origem; era integrado à equipe da Opas. Por exemplo, eu poderia ter sido indicado pelo Ministério da Saúde, mas estaria lá como membro do GAP, faria parte de uma força-tarefa independente, coordenada pelos mecanismos regulares da Opas. [...]

\footnotetext{
82 Lia Celi Fanuck formou-se em Direito e especializou em Legislação Sanitária. Juíza aposentada, foi subsecretária de Recursos Humanos do Ministério da Saúde e assessora da Secretaria Nacional de Vigilância Sanitária do mesmo ministério.
} 
Como poderíamos caracterizar as relações estabelecidas entre a equipe técnica central da cooperação com os executivos estaduais e a universidade?

Carlyle Guerra de Macedo - Um dos fundamentos do Ppreps era o trabalho com as secretarias de saúde. A descentralização que propúnhamos naquele momento não chegava até o município. Estava fora de questão pensar numa descentralização a esse nível, a não ser em municípios muito grandes. Então a filosofia de trabalho do Ppreps era atuar com as secretarias estaduais de saúde, que depois o disseminariam para os municípios. Dificuldades sempre existem, mas não me lembro de nenhuma secretaria com a qual tivemos problemas maiores, além do que a situação normalmente justificava. Também não me lembro de nenhuma extraordinariamente exitosa. Com algumas tivemos mais afinidade, por exemplo a da Bahia, com quem depois, com o novo Prev-Saúde, também houve uma relação especial. Mas era mais uma afinidade com as pessoas de lá. Já com as universidades avançamos muito pouco.

Roberto Nogueira - Junto às secretarias estaduais, nossa proposta era de capacitação de planejamento das ações de recursos humanos, formação de quadros com cursos. [...] No início pouco se mexia com planejamento e gestão de pessoal; praticamente não se falava nessa parte. Logo depois a temática foi introduzida por conta das carreiras, mas nosso foco inicial foi o processo interno de formação de pessoal para as secretarias estaduais. Havia um sistema muito centralizado, que era pré-SUS, então a nossa contrapartida eram as secretarias estaduais de saúde. A cooperação técnica se fazia basicamente na linha educacional para nível médio e em alguns processos de educação permanente, em termos de especialização, de residência médica, que estavam aparecendo.

José Paranaguá - A Opas não inventa um projeto, não decide sobre as ações A ou B. Ou é um programa regional aprovado pelo Conselho de Ministros, que é o órgão deliberativo superior da organização, ou é um projeto acordado entre a representação e a autoridade nacional ou estadual. A Opas não tem poder de intervenção e execução próprias, e trabalhar com essa lógica é vantajoso do ponto de vista da perpetuidade, da permanência de objetivos, que são indispensáveis para uma boa administração pública [...].

O princípio básico era que qualquer ação de cooperação técnica da Opas nos estados dependia da anuência ou participação efetiva do governo federal — fosse através do Ministério da Saúde, da Educação ou da Previdência - e dos dirigentes da instituição no estado — fosse a universidade, através 
de uma de suas unidades, ou o secretário de saúde e a equipe técnica local responsável por aquele projeto. Mas a troca de secretário e os períodos de transição de governo sempre levam à redefinição de prioridades e diretrizes, às vezes até de orientação do próprio projeto. A vantagem é que as autoridades estaduais, municipais, universitárias ou educacionais têm uma visão muito positiva, às vezes até idealizada, de organizações internacionais como a Opas, e as vêem como instituições neutras, sem ingerências de política partidária. Então, em estados onde o governo é de um outro partido que não o do governo federal, as relações entre a Secretaria de Saúde e o Ministério da Saúde, em geral, têm de levar em conta essa vicissitude. Isso era amenizado com a participação da Opas, e em situações de transição de governo estadual ou de gestão universitária nós sempre lançamos mão dessa vantagem para manter a continuidade e garantir a sobrevivência dos projetos que iam bem.

Roberto Nogueira - Quando eu estava no Ministério da Saúde, em 1977, 1978, nossa perspectiva era mais interna. Com exceção de alguns cursos que apoiávamos com recursos - como aquele de especialização em saúde com duração de quatro meses, em São Paulo —, nossa atuação era mais voltada para o planejamento dos recursos humanos internos. Não tínhamos ainda uma perspectiva de cooperação técnica com as secretarias estaduais. Ela só se formou no início dos anos 1980. Aí então partimos para apoiar, nos estados, os órgãos de recursos humanos, como eram chamados, para formar capacidade administrativa nas secretarias que desse conta da problemática de recursos humanos, que quase nunca existia; o que havia eram órgãos de planejamento que cuidavam da gestão de pessoal.

De qualquer modo, eu vivenciei pouco a relação do GAP com as secretarias estaduais. Sei que em cada secretaria estadual havia de uma a três pessoas nas áreas de recursos humanos ou de planejamento, e era com elas que se montavam cursos ou outras formas de atualização de pessoal. No início predominavam atividades para o auxiliar de saúde — uma massa não-qualificada na época — que resultaram, mais tarde, no Projeto Larga Escala. Nossa área prioritária de cooperação era o Nordeste. Um pouco o Norte, um pouco Minas Gerais, com Montes Claros, mas sobretudo o Nordeste. Trabalhávamos de certo modo com a perspectiva da Sudene: o reforço a essas áreas do país que têm menos desenvolvimento social, econômico e sanitário. Havia a contrapartida das secretarias e das universidades. Nestas era a IDA [Integração Docente-Assistencial] e a das secretarias era mais a formação de pessoal de nível elementar. 
Cesar Vieira - Nós tínhamos boas relações com a Universidade Federal do Rio de Janeiro, por causa do Nutes/Clates e outros projetos, tínhamos boas relações com a Unicamp, com a Federal de Pernambuco, com a Federal de Minas Gerais. Nossos laços com a Abrasco facilitaram muito a relação com as universidades, sobretudo na área de saúde coletiva.

Até que ponto propostas e experiências descentralizadoras eram incompativeis com o contexto político do regime militar, nos anos 1970, marcado pela centralização politica?

José Paranaguá - Em essência, a descentralização não tem contradição com o regime autoritário. A descentralização, a racionalização, a eficiência administrativa eram objetivos do governo autoritário. Depois que o governo Vargas — também um governo autoritário — montou a máquina administrativa do poder público no Brasil, o novo salto de qualidade da administração pública brasileira se deu durante a ditadura militar, especialmente na década de 1970. [...] A repressão se fazia noutro campo; era na opção de militância partidária, na organização sindical e em termos muito pessoais. O mesmo discurso na boca do Sérgio Arouca ou do Hésio Cordeiro era proibido e na boca do ministro da Saúde e do secretário-geral era oficial. Era complicado o Sérgio Arouca falar em descentralização numa palestra, mas o ministro da Saúde, ou o secretário-geral Paulo de Almeida Machado ${ }^{83}$, ou o doutor Seixas falarem era normal, estava na lei do Sistema Nacional da Saúde. A repressão agia muito mais sobre o ator que falava do que na substância.

Ainda que a descentralização pudesse ser considerada um componente meramente racionalizador, o Ppreps e outras iniciativas no ambito do poder executivo constituiram-se em espaços concretos de ação política. Como isto funcionava?

Alberto Pellegrini - O Estado brasileiro deixou brechas para que grupos mais progressistas participassem da administração pública, em vários níveis. Entre as secretarias de saúde do Nordeste, havia, por exemplo, a de Alagoas, onde o secretário permitia que o grupo de sanitaristas apresentasse

83 Paulo de Almeida Machado, mineiro de Uberaba, formou-se em medicina pela Universidade Federal do Rio de Janeiro em 1938. Foi Ministro da Saúde entre 1974 e 1979, na gestão do Presidente Ernesto Geisel. Foi Diretor de Desenvolvimento Social do Conselho Nacional de Desenvolvimento Científico e Tecnológico (CNPq). 
propostas bastante arrojadas, inclusive com participação comunitária, mobilização da comunidade, coisas que, pouco antes, eram vistas com muita suspeição. Mas nem todas as secretarias eram assim, e por isso nossas dificuldades variavam conforme os grupos. Os documentos do Piass já adotam uma linguagem muito mais aberta. O próprio Ministério da Saúde cujo Secretário Geral, na época, era o José Carlos Seixas — abria muito espaço. O Ipea sempre foi mais aberto; a Previdência nem tanto. Mas sem dúvida a proposta do Piass e a sua expansão só se deram porque já havia espaço para propostas desse tipo.

Roberto Nogueira - Em nosso trabalho, todas as questões partiam da análise da conjuntura nacional. Nós nos reuníamos muito regularmente e as abordagens giravam em torno do que acontecia no país e da formulação de políticas nacionais. Tanto é assim que eu tinha a impressão de que éramos agentes de formulação de políticas públicas feitas em uma instituição internacional. O compromisso ou sentido de vinculação com o governo era maior do que com os organismos internacionais e as suas diretrizes. Isso é muito singular; era como se estivesse reservado, dentro de um organismo internacional, um espaço para que o próprio governo formulasse as suas diretrizes, para que houvesse um espaço de pensamento. É claro que isso não se dava muito pacificamente, porque tínhamos uma vida relativamente independente do próprio governo.

Acho que a situação tinha a ver com a lógica da ditadura. Ela não podia fechar todos os espaços de pensamento, então criou algumas instituições de excelência, de reflexão, de educação, em que havia autonomia e ninguém mexia. Talvez tenha sido este o caso da Opas no Brasil, como também o do Ipea, na época. Era a época de abrir os espaços, e a ditadura permitia que nós os abríssemos. Politicamente nos articulávamos em várias frentes, dentro do próprio grupo e fora também. Na passagem dos setenta para os oitenta, no início desta década, aconteceram os primeiros simpósios de saúde da Câmara, e o GAP teve um papel importante nisso. Essas iniciativas do grupo eram quase clandestinas; não havia oficialização nenhuma [...] Tinha a ver, sim, com o momento de crescimento de participação política, nossa e da sociedade como um todo. Estávamos na redemocratização. Então, nós tínhamos interesse em extrapolar os limites institucionais como cidadãos e também como intelectuais. 
A formação de pessoal de saúde em nivel médio e elementar é considerada um dos aspectos fundamentais da cooperação técnica Opas-Brasil, como esta linha de trabalho se desenvolven até culminar no chamado Projeto Larga Escala?

Roberto Nogueira - O Larga Escala está muito ligado ao carisma da Izabel [dos Santos] desde o início até o final, se é que houve um final. Eu menciono a Izabel dos Santos como figura importante, mas foi se forjando toda uma cultura que, depois, deu origem ao Projeto Larga Escala. A qualificação dos agentes de saúde foi um dos primeiros projetos do Ppreps. O propósito era qualificar o pessoal que estava ingressando na Secretaria de Saúde para constituir a rede de expansão de cobertura, iniciada nos anos 1970, mas que possuía baixo nível de escolaridade e poucas habilidades. Esta linha daria, mais tarde, no Larga Escala. Inicialmente eram só cursos de qualificação, não havia a proposta de um processo formal de educação que levasse à titulação em nível médio, como depois o Larga Escala veio colocar.

O Larga Escala foi formulado na Opas, onde foi possível a um grupo afastar-se do dia-a-dia da burocracia ministerial e realizar um trabalho bastante técnico. Mas ele implicou uma divisão de trabalho dirigida mais para os estados e municípios do que para o governo federal. O Ministério da Saúde participou muito pouco desse processo, o que naturalmente deu margem a ciúmes. Eventualmente os técnicos do ministério eram chamados para uma ou outra etapa, mas o trabalho se exercia basicamente através da Opas em articulação com o MEC. Então os técnicos do Ministério da Saúde não se identificaram com esse programa. Ele nasce, cresce e se expande ou morre como iniciativa da Opas, identificada na pessoa de Izabel dos Santos. [...]

Acho que o Ppreps acumulou muita experiência na área da formação de nível elementar graças a Izabel. Ela sempre trabalhou com pessoal auxiliar. Ainda quando estava na Universidade Federal de Pernambuco, já se envolvia com a integração entre ensino e trabalho. O que o Ppreps fez foi fomentar essa integração no próprio ambiente de trabalho, e não a partir da escola. A idéia era que a educação permanente verdadeira se dá no local de trabalho.

Havia vários mecanismos de supervisão. Era grande o interesse por eles, no início da década de 1980, porque se imaginava que os supervisores do pessoal auxiliar tinham também uma função educacional, que atuavam como educadores.

IZABEL DOS SANTOS - Comecei a desenvolver um trabalho na Escola de Enfermagem em Recife que vim saber, mais tarde, que poderia se chamar 
integração docente-assistencial. Já disse que sou uma pessoa que começo a fazer as coisas e no fazer é que eu vou compreendendo as relações, descobrindo e formando novos conceitos. Eu estava ensinando na Escola de Enfermagem e naquela época o ensino de enfermagem tinha três anos comuns, a todos os alunos, e no quarto ano diversificava. Os alunos podiam fazer Saúde Pública, Obstetrícia ou outro que não me lembro agora. Eu ministrava a disciplina Saúde Pública e pensei que seria interessante levar a disciplina para dentro de um centro de saúde. A idéia era, no decorrer do curso, organizar o serviço de enfermagem. Então passei, a cada ano, a ministrar a disciplina em um centro de saúde diferente. $\mathrm{Na}$ época existiam apenas cinco centros de saúde, em Recife. A essência do curso era como se organizam as rotinas, como se elaboram as normas, como se faz treinamento, como se avaliam os serviços, enfim, como se organiza uma unidade de saúde.

Nessa experiência, eu verifiquei o seguinte: primeiro, que o processo de ensino tem uma força geradora de energia, de entusiasmo, de afeto das pessoas muito importante para um processo de mudança; segundo, que vários outros atores passaram a participar do processo de ensino, quero dizer, foram ouvidos o diretor da unidade de saúde, a enfermeira-chefe, os atendentes de enfermagem e outros componentes da equipe. $\mathrm{O}$ importante não era, apenas, ao término do curso se ter o processo de produção sistematizado, organizado, normatizado, com rotinas, protocolos e atribuições claramente definidos; o mais significativo era a participação e aceitação do diretor e das demais chefias da unidade de saúde na reorganização do serviço. Dessa forma todos aprendíamos. Os alunos, vivendo uma situação real, aprendiam com mais segurança. Eles enfrentaram oposições, tiveram dificuldade de obter consenso, enfim, eles conheceram e viveram várias situações inerentes ao processo de reorganização de serviço.

Este foi um trabalho que teve muita repercussão. Veja, eu nunca tinha ouvido falar em qualquer projeto sobre integração de ensino e serviço, só vim saber que o que eu estava fazendo se chamava assim quando cheguei a Brasília. Mas quando eu saí de Recife já tinha uma experiência do fazer, tinha as coisas mais ou menos claras na minha cabeça, porque a gente nunca sabe direito as coisas, não é?

Carlyle Guerra de Macedo - Esta era uma das áreas que acreditávamos ter maior probabilidade de ser realizada, a área de menor resistência a mudanças. Esperava-se que a formação significasse também uma melhora das 
condições de emprego para esse pessoal, por isso não esperávamos muita oposição ao desenvolvimento do projeto nesta área. De fato, como proposta e discurso o Larga Escala teve aceitação institucional quase unânime. As dificuldades eram de caráter operacional, mas para isso contamos com esse 'motor' que é a Izabel. O grande problema era a lentidão na mudança das regras que regem a formação de pessoal no Brasil. Este foi o grande entrave que custou muito a ser resolvido, e até hoje acho que ainda há algumas lacunas nesse aspecto.

Roberto Nogueira - Era o início dos anos 1980 e o GAP [Grupo Assessor Principal ${ }^{84}$ funcionava havia dois ou três anos. No Prev-Saúde estávamos avaliando a qualificação dos agentes de saúde, um pessoal com baixo nível de escolaridade, baixa capacidade técnica, uma massa de gente trabalhando nos postos e centros de saúde. Se nos anos 1970 a preocupação era qualificar por meio de pequenos cursos de reciclagem ou aperfeiçoamento desses trabalhadores, na década de 1980 surgiu a preocupação de titulá-los, fazer com que eles chegassem a dispor de um diploma.

Primeiro criamos a habilitação parcial de visitador sanitário. [...] A família de ocupações reconhecidas pelo MEC era composta pelo técnico de enfermagem, com habilitação plena, pelo auxiliar de enfermagem, com habilitação parcial, e foi incorporado a ela a ocupação de visitador sanitário, também uma habilitação parcial, porém sem titulação. Então surgem duas preocupações simultâneas. Uma delas era dar a esse trabalhador um diploma, para que ele não fosse apenas qualificado em serviço. Com uma titulação ele seria alçado à condição de cidadão pleno. Isso passava por uma articulação grande com o MEC, com os conselhos federais e com os conselhos estaduais de educação. A outra preocupação era fazer isso em um processo integrado de educação e serviço, utilizando-se os supervisores dos centros de saúde como professores e incorporando-se uma metodologia um pouco mais emancipatória, inspirada em Paulo Freire, com todas as adaptações necessárias. Nesse trabalho foi fundamental a contribuição da Izabel — sempre uma inspiradora - , da

84 O GAP foi instituído em 1978, em substituição ao Grupo Técnico Central (GTC) como a principal instância de coordenação executiva da cooperação. Para mais detalhes, ver capítulos 3 e 4. 
Hortênsia Holanda ${ }^{85}$, uma educadora sanitária que havia sido consultora da OMS em vários países, e da Cristina Davini ${ }^{86}$, pedagoga e assessora da Argentina que estava no Brasil, nessa época.

Izabel dos Santos - O Projeto Larga Escala, no sentido estrito da palavra, nunca existiu. Ele era uma idéia, não tinha dinheiro, não tinha meta, era uma idéia. Eu tinha muito claro todos os seus componentes de como eles deveriam ser. Mas, a rigor, não se poderia chamá-lo de projeto. Acho que para a sua construção foi muito bom não ser projeto, pois não se tinha prazo, você podia seguir o ritmo dos acontecimentos. Dessa forma, eu não posso chamálo de projeto, como o Profae [Projeto de Profissionalização dos Trabalhadores da Área de Enfermagem], por exemplo, que tem um prazo de quatro anos e tem um financiamento externo. O Larga Escala não tinha dinheiro algum, as coisas conseguidas foram na conversa. [...] Talvez fosse mais um movimento. Falar em projeto para o Larga Escala, é usar um termo inadequado.

\section{Como se deu o processo de desenvolvimento do chamado Projeto Larga Escala, inclusive em seus aspectos metodológicos?}

Roberto Nogueira - Primeiro tratamos de preparar os instrumentos de qualificação dos supervisores. Depois saímos pelos estados de todo o país promovendo seminários de qualificação dos instrutores, primeiramente para os cursos de visitador sanitário e, em uma segunda etapa, para as demais cate-

85 Nascida em 26 de maio de 1917, na cidade de Corumbá, Mato Grosso do Sul, Hortênsia Holanda concluiu cursos de Língua e Literatura Anglo-Germânica, na Faculdade de Filosofia, em 1941, e outro de Nutrição, na Universidade Federal do Rio de Janeiro, em 1949. Especializou-se em Saúde Pública e Educação em Saúde na Escola de Saúde Pública da Universidade do Chile, em 1950, tendo feito mestrado em Saúde Publica e Educação na Universidade da Califórnia, em 1952. De 1949 a 1955, foi assistente técnica da Divisão de Educação Sanitária do Serviço Especial de Saúde Pública. A partir de 1954, atuou no Departamento Nacional de Endemias Rurais. Em 1963, ela foi contratada da South Pacific Commission, atuando em vários países e territórios do Pacífico. Foi consultora da Organização Mundial da Saúde (1968/1969), para programas em vários países. De 1970 a 1977, foi assessora e diretora da Divisão Nacional de Educação Sanitária do Ministério da Saúde, sendo também consultora de secretarias de saúde nos estados. Como fellowship da World Health Organization - WHO (1958), Hortênsia participou de programas sobre esquistossomose e malária em países africanos. Foi bolsista da Usaid (1960) e da American Cancer Society (1973). Foi também responsável por projetos voltados ao desenvolvimento de materiais educativos audiovisuais com a participação das populações rurais (De acordo com informações obtidas com Lisabel Klein, a quem agradecemos).

86 Maria Cristina Davini, argentina, é doutora em Educação pela Pontifícia Universidade Católica do Rio de Janeiro. Foi Diretora Geral de Educação Superior da Secretaria de Educação da Cidade de Buenos Aires. É professora da Universidade de Buenos Aires é consultora de educação do Campus Virtual de Saúde Pública, da Organização Pan-Americana da Saúde. Ver: cache de http:/ /educalibros.com.ar/Entrevistas/Entrevista2.asp na ferramenta Google, obtida em 10 ago. 2005 
gorias. Isso implicou um trabalho operacional muito interessante, e aprendemos muito com essa interação. Foi um processo artesanal, se comparado com a experiência posterior do Profae [Projeto de Profissionalização dos Trabalhadores da Área de Enfermagem], e caracterizado por uma grande centralização - talvez a Izabel não concorde muito com isso. Não delegamos para ninguém a elaboração dos primeiros manuais de capacitação por receio de pôr a perder a filosofia pedagógica do Larga Escala. Queríamos fazer uma qualificação antitaylorista, fazer pensar o mundo a partir da função que se desempenha, e por isso nos encarregamos pessoalmente desses manuais. Depois o trabalho foi descentralizado; houve inclusive a contribuição da Universidade Federal de Minas Gerais.

Alberto Pellegrini - O projeto da Izabel tem duas vertentes. Uma é a capacitação e o treinamento de auxiliares de saúde em larga escala. Sobre esse aspecto, a Izabel sempre insiste na questão técnica, na importância de uma metodologia que permita formar um grande contingente de profissionais. A Fundação Sesp tinha um programa de capacitação, mas uma coisa é trabalhar com algumas pessoas, outra é formar centenas. A segunda vertente é a legitimação desse profissional. Foi grande o trabalho da Izabel, junto ao Ministério da Educação, para reconhecer as profissões de modo que o aluno que fizesse um curso em uma secretaria de saúde tivesse uma profissão reconhecida, garantindo-lhe um mercado de trabalho nacional. A Izabel saiu-se vitoriosa nas duas vertentes. Conseguiu desenvolver uma metodologia de capacitação em larga escala e obteve o reconhecimento desses níveis profissionais, que antes eram marginais.

IZABEL DOS SANTOS - Eu mexia com treinamento e não fazia nenhuma diferença de significado entre treinar e formar. Em um desses treinamentos, em Minas Gerais, uma agente de saúde me abordou da seguinte forma: "Moça, estou cansada de fazer treinamentos que não servem para nada. Não há um jeito de fazer uma coisa que possa me beneficiar depois?" Ela estava se referindo à construção de processos que oportunizassem futuros aproveitamentos de estudos e possibilidades de complementação que a fizessem galgar patamares de processos educativos mais avançados. Diante da pergunta dessa moça, comecei a refletir sobre a diferença que fazia um diploma. Comecei a perceber que, com o diploma, o trabalhador/aluno poderia se apresentar em qualquer ponto do país e teria um reconhecimento, teria uma profissão. Sem um diploma, ele poderia ser muito bem qualificado para a instituição, todavia 
ele não poderia disputar no mercado de trabalho, enfim, não teria o direito de sair da instituição. Quando eu fui descobrindo isso, pensei, "nossa! a tarefa é maior do que imaginei". Porque aí eu já estava intuindo que teria de pensar uma outra escola, pensar um outro processo educacional e teria, também, que fazer com que as pessoas se interessassem por essa mudança. O que, supus, seria o mais difícil.

Que escola seria essa? A minha experiência dizia que a escola formal, regular, pouco seria útil para o aluno/trabalhador que tinha sido excluído, em algum momento de sua vida, dos bancos escolares formais. Portanto, ela teria que ter, como princípio primordial, a inclusão. Como fazer isso? Foi a partir daí que eu comecei a formatar a idéia de que a escola para esse aluno/trabalhador deveria ser algo flexível; ele não poderia ser obrigado a ir até ela todos os dias; o professor não deveria ser um mero transmissor de conhecimentos. Dessa forma, passei a perceber que essa escola deveria ter regimentos diferentes, currículos diferentes, ofertar cursos descentralizados, pensar na qualidade da assistência de saúde prestada e formar instrutores e supervisores de ensino em processos técnicos e pedagógicos diferentes. Pressenti uma missão difícil.

Cesar Vieira - Eu acho que a nossa experiência mais relevante foi com o pessoal auxiliar, que culminou no Larga Escala. Porque a integração docente-assistencial não foi muito importante, talvez por não termos na época os instrumentos necessários. O mesmo aconteceu com a área da educação superior. Já o Larga Escala eu acho que teve resultados importantes. Primeiro porque é um nicho muito definido. Depois porque alguns desenvolvimentos na área educacional favoreceram o projeto. Trabalhando com a questão do ensino profissionalizante e técnico, ele ajudou aproximar o setor saúde desses novos desenvolvimentos da área de educação.

IZABEL dos SANTOS - A escola que eu pensei foi pensada intuitivamente a partir dos dados que o contexto me apontava. Eu pensei que essa escola deveria ser diferente porque ela teria um novo cliente e este novo cliente é um trabalhador adulto que vai cursar o ensino técnico. Portanto, a escola de formação técnica tem que ser diferente da escola de formação geral, ela tem que ter um compromisso com o fazer, com a aplicação do conhecimento, com a prática, com o desempenho.

A escola, em vez de ser uma escola endereço, passa a ser uma escola função. Isso quer dizer que ao invés do aluno ir todos os dias para a escola em 
horários programados, a escola é quem vai ao aluno, no seu ambiente de trabalho. O docente, em vez de ser um cargo, passa a ser uma função. Nessa concepção de escola função é que se baseia toda a descentralização dos cursos, a busca de atender às necessidades do cliente trabalhador e do cliente gestor dos municípios mais distantes. Ou seja, ela rompe com os pressupostos da escola regular.

Eu não aceitava, de forma alguma, fazer uma escola de formação técnica baseada nos pressupostos de uma escola de educação geral. Eu não aceitava também que escola fosse só cadeiras, paredes e quadro-negro. Eu achava que a escola, para ser escola, devia ter um corpo filosófico, ou seja, todos aqueles que fazem aquela escola devem ter uma concepção de homem, de sociedade, de educação, de direitos à saúde, de serviços de saúde. Eu achava que a saúde era muito importante e que o processo de produção dos serviços de saúde era muito complexo para ser jogado numa vala comum do setor terciário. Quem trabalha numa escola de formação técnica de saúde não pode ignorar isso.

Eu acho que uma escola tem que ter um arcabouço filosófico, político e cultural para poder definir a missão dela e fazer a sua projeção para o futuro. Com base nisso é que ela deve organizar um regimento, coerente com esse projeto político pedagógico, que deve ser autorizado pelo sistema educacional para que ela possa atuar. E como essa escola tem os trabalhadores de saúde como docentes, eles também devem participar da construção desse projeto. A turma que pensa a escola pela escola acha que a escola é que tem que definir as suas prioridades, eu sempre neguei isso. A escola tem que trabalhar em parceria com o serviço de saúde. Quem define as prioridades é o serviço, o planejamento tem que ser conjunto.

Desde a primeira renovação do Acordo, em 1978/1980, a cooperação técnica vivencia um processo de ampliação de seu escopo original, como se deu esse processo?

Alberto Pellegrini - O final dos 70 e inicio dos 80 foram de intensa atividade. Trabalhávamos com a CNBB [Conferência Nacional dos Bispos do Brasil], a Comissão de Saúde da Câmara, o Cebes [Centro Brasileiro de Estudos de Saúde] e outras entidades... O Acordo cumpriu um papel importante de mobilização da sociedade civil e da burocracia do Estado. Não havia espaços de interação entre o MEC, a Previdência, a Saúde, e o Acordo rompe essa fragmentação, tornando-se um espaço de intercambio e consenso. Não 
foi à toa que o Prev-Saúde, que tinha de ser um projeto integrado entre a Previdência, a Saúde e a Educação foi buscar apoio no Acordo com a Opas.

Quando o Ministério da Previdência me indicou para integrar o Acordo, continuei trabalhando com o Mozart de Abreu, só que vinculado ao espaço do Acordo, o que possibilitava nossa interação com os diversos ministérios. Embora tivesse uma trajetória na área de recursos humanos, por minha participação em experiências inovadoras de educação médica em Campinas, fui para o Acordo integrar-me mais diretamente na área de organização dos serviços, uma outra área importante de trabalho que o Acordo passou a incorporar a partir do Prev-Saúde. Posteriormente o Acordo incorpora também a área de Pesquisa em Saúde, à qual me vinculei depois da experiência do PrevSaúde. A área de recursos humanos prosseguiu com Izabel dos Santos, José Paranaguá, Roberto Nogueira e outros.

Cesar Vieira - Eu estive no Ppreps de 1976 e 1979. Fui para Inglaterra e, quando voltei, fiquei no programa de 1982 a 1985, quando ele já havia se ampliado. Antes o Ppreps trabalhava só com recursos humanos. Nós éramos um grupo grande, mas as áreas de serviços de saúde, de planejamento não. Às vezes tinha alguma cooperação, mas recursos humanos era o nosso nicho, $\mathrm{e}$ nosso trabalho era definido com o Ministério da Saúde e o MEC, os dois organismos que participavam do acordo. $\mathrm{Na}$ segunda fase entraram dois outros ministérios, o da Previdência e o de Ciência e Tecnologia, e então começamos a atuar em desenvolvimento científico-tecnológico, com serviços de saúde, nos envolvemos mais com a questão da reforma sanitária e a criação do SUS. Antes era Programa de Preparação Estratégica de Pessoal de Saúde, depois virou Programa de Desenvolvimento de Recursos Humanos em Saúde e no final passou a se chamar Programa de Infra-estrutura. Mas já estávamos trabalhando nesta área antes disso. Era muito difícil manter gente como Carlyle, eu e outros restritos à questão de recursos humanos. Por mais que gostássemos de ensino, estávamos envolvidos em outras áreas. Tínhamos interações muito boas com o pessoal do Ipea e outras instituições e começamos a atuar em outros trabalhos. Nós participamos e apoiamos as Conferências Nacionais de Saúde, por exemplo.

Roberto Nogueira - Anteriormente o grupo era só de recursos humanos. Depois ele incluiu gestão e planejamento de serviços, e entrou também ciência e tecnologia, que o Pellegrini gradativamente assumiu. [...] Entre o final dos anos 1970 e início dos 1980, o grupo passou a ter, então, a atribuição de 
formulação estratégica para o sistema de saúde como um todo. Isso teve a ver não só com a natureza do convênio, mas também com a entrada de Waldir Arcoverde $^{87}$ no Ministério da Saúde, com quem Carlyle tinha um relacionamento pessoal. Arcoverde, que era uma figura estratégica para a Opas, passou a ser também da estrutura do governo, assim como o Mozart [de Abreu e Lima], que era Secretário Geral do ministério. E começamos a formular coisas que desembocaram no Prev-Saúde. [...]

O Programa de Infra-estrutura, apenas totalmente formalizado em 1986, abrangia as áreas de serviços e de recursos humanos, além de ciência e tecnologia. Isso implicou uma reacomodação que dava ainda mais autoridade e expressão ao grupo nacional da Opas, dentro e fora do Brasil. Nós não atuávamos na essência das várias áreas técnicas. A atenção à saúde da mulher e da criança, a tuberculose, a malária sempre estiveram em mãos de especialistas que contribuíam para a Opas, na cooperação técnica. A infra-estrutura é uma área integrada de conhecimento, que faz planejamento de uma espécie de capacidade instalada para produzir os serviços. Ela pensa as grandes lacunas dos serviços e a organização deles: quais são os níveis de atenção? Como eles se relacionam com a necessidade de recursos humanos? Qual é o papel da ciência e da tecnologia? Como isso tudo repercute na atenção à mulher, à criança, ao trabalhador, aos vários tipos de enfermidades? E esse trabalho exige aportes técnicos específicos, que eram dados geralmente pelo pessoal internacional. [...] Então foi difícil fazer valer a nova perspectiva dentro da Opas, porque não era esta a conformação das várias divisões em Washington, onde sempre se atuou com grupos programáticos conforme temas específicos.

Cesar Vieira - Minha atividade na coordenação do programa foi muito diferente, porque passamos a ter um apoio muito grande da Opas depois que o Carlyle assumiu a direção em Washington, [em 1983]. Nossa situação era ótima: já havia uma boa relação com o governo nacional, com as secretarias em geral a relação foi sempre boa e passamos a ter uma relação muito boa também com a Opas. Em vez de ser um grupo meio marginal na organização, passamos a ser da situação, e isso nos facilitou muito. [...]

Carlyle fez algo conosco que era diferente do resto da Opas. Nós tínhamos um programa de trabalho, coordenado pela Comissão de Coordenação.

87 Piauiense de Amarante, onde nasceu a 23 de setembro de 1932, Waldir Mendes Arcoverde diplomou-se em medicina pela Universidade Federal do Paraná. Foi secretário de Saúde do Rio Grande do Sul e, entre 1979 e 1985, foi ministro da Saúde no governo Ernesto Geisel. Ver: http:/ /dtr2001.saude.gov.br/bvs/popup/estrutura/ministros/galeria.html (Acesso em 01.08.2007) 
Depois nós quisemos incorporar o programa de recursos humanos no marco da Ciplan, [Comissão Interministerial de Planejamento e Coordenação], porque entrou o Programa de Ações Integradas em Saúde, as Pais, e queríamos expandir o nosso programa. Sentíamos que precisávamos expandir; não dava para ficarmos restritos à formação de pessoal. E a proposta era bem acolhida pelas secretarias de saúde. Eles estavam se sentindo órfãos e nós, bem ou mal, éramos um mecanismo possível. Os cursos, seminários e oficinas que fazíamos acabavam incorporando outros temas, tanto por sugestão nossa, quanto por demanda deles.

Alberto Pellegrini - Quando [em 1983] o Carlyle assumiu a direção da Opas em Washington, fez uma alteração nos contratos de trabalho. Havia anteriormente apenas o cargo de consultor internacional, com todas as regalias e custos que implicava. Durante a gestão do Carlyle como diretor da Opas, criaram-se novas formas de contrato, e uma delas era a de consultor nacional, que foi experimentada primeiramente aqui no Brasil. Nosso grupo do Acordo passou a ser contratado segundo esta modalidade que virou um modelo para outros países. A Opas passou então a contratar mais amplamente profissionais nacionais para atuarem em seus próprios países.

José Roberto Ferreira - Em 1983, Cesar Vieira assumiu a direção do Ppreps. Nessa época extinguiram-se os postos internacionais, criou-se a figura do funcionário nacional e por isso a equipe foi ampliada. O convênio continuou vigindo, mas o nome Ppreps talvez tenha começado a desaparecer aí. $\mathrm{O}$ grupo de trabalho, porém, permaneceu. Izabel dos Santos continuou por mais dez anos, Roberto Nogueira ficou até ir para Washington e Paranaguá está aí até hoje. A diluição do Ppreps se deu aos poucos. O que deixou de haver foi a transferência de dinheiro brasileiro para a Opas transformar em salário. Os salários passaram a ser pagos em moeda nacional, mas pela Opas.

Simultaneamente, a cooperação Opas-Brasil participou ativamente das discussões em torno da formulação daquele que seria o Programa Nacional de Serviços Básicos de Saúde (Prev-Saúde). No contexto da cooperação técnica Opas-Brasil em RH, qual o significado deste programa?

Alberto Pellegrini - O Prev-Saúde não caiu do céu; ele é resultado de um processo que inclui experiências anteriores como o Piass e Montes Claros e toda uma discussão que o movimento sanitário promoveu desde os 
anos 1960. Vários intelectuais, na época, admitiram que o Prev-Saúde reunia grande parte do que o pensamento sanitário brasileiro tinha acumulado até aquele momento. A começar pelo reconhecimento de um setor informal de saúde, que passava a fazer parte do próprio sistema. Depois, pela definição clara de atribuições de um setor formal de serviços básicos, de atenção de primeiro nível, que seria basicamente estatal com o setor privado jogando um papel suplementar. E, ainda, um nível secundário e terciário com forte participação estatal, mas já admitindo presença importante de setor privado. Com essa proposta, o Prev-Saúde começava a discutir o que o movimento sanitário ainda não contemplava na época, que é a relação entre os setores público e privado de saúde. [...]

O projeto era bem completo. Abordava desde detalhes arquitetônicos das unidades básicas, suas funções, o tipo de especialistas que teriam, a relação com os vários níveis do sistema, até a parte financeira. Ele recuperava o que tínhamos acumulado até então: a experiência do Piass [Programa de Interiorização das Ações de Saúde e Saneamento], dos serviços básicos de saúde, da atenção primária. E tinha muito a ver, também, com o que estava acontecendo na Opas e na OMS, quanto ao movimento da atenção primária. Ao mesmo tempo nós participávamos de toda a dimensão política do projeto. Acompanhávamos a Comissão de Saúde da Câmara se pronunciando em relação ao Prev-Saúde; os ministros defendiam-se das críticas da Comissão de Saúde, e nós também colaborávamos na redação dessas defesas; estávamos presentes na imprensa, dando várias entrevistas sobre o projeto. Enfim, nós circulamos o Brasil inteiro vendendo o Prev-Saúde.

Eu entrei para participar do Prev-Saúde e nele fiquei durante quase um ano e meio. Minha participação se dava em vários níveis. Como em tudo, naquela época, o trabalho formal era muito misturado com a militância política. Na redação do Prev-Saúde, trazíamos pessoas para nos ajudar nos aspectos financeiro, técnico etc. O grupo era coordenado pelo Carlyle; a mim coube, mais diretamente, participar na redação do documento.

Roberto Nogueira - Esse programa foi feito quase na clandestinidade, vamos dizer assim. O grupo técnico se reunia em Brasília. Era o primeiro esforço de aproximação entre os Ministérios da Previdência e da Saúde para fazer uma ação integrada, um interesse inédito de conjugação de esforços. E nada podia ser divulgado; nós nos reunimos, discutimos e produzimos o documento em condições de sigilo. Mas as informações acabaram vazando, a 
imprensa publicou, e desde o início houve opiniões contrárias. Para nós, estávamos no início de uma revolução. Só que não éramos a ponta daquela revolução, mas de outra que veio acontecer muito tempo depois, com o SUS. Na verdade, eu fui chamado a participar disso pouco marginalmente, para escrever algo sobre as equipes do centro de saúde básica. Eu não tive muita participação na formulação da estrutura geral do documento. [...] É claro que o projeto mais importante do grupo foi o Prev-Saúde. Ele foi abortado, mas dele surgiram muitas idéias que geraram políticas, sobretudo a de atenção básica de saúde.

Alberto Pellegrini - O Prev-Saúde era muito ambicioso, com um custo bastante elevado e com a expectativa de que os recursos viriam do sistema previdenciário. Uma projeção, feita por economistas, previa o crescimento da arrecadação da Previdência. Estávamos em 1979, ainda havia uma certa euforia na área econômica, resquício do grande crescimento da década, e esperava-se que, com a arrecadação da Previdência cada vez maior, haveria recursos suficientes para financiar o projeto. [...] O Prev-Saúde foi enterrado como projeto de construção de novas unidades e contratação de pessoal, mas como proposta continuou muito vivo. Foi um momento de gestação de idéias e propostas de uma política nacional de saúde, de organização de um sistema de saúde que deu frutos, sem dúvida.

A crítica da Previdência Social centrava-se na questão financeira, nos custos de manutenção dos serviços, porque afinal era ela quem teria de bancar. Já entre a intelectualidade, houve pessoas como o Hésio Cordeiro $^{88}$, por exemplo, que apoiou muito o Prev-Saúde, sendo um de seus grandes defensores, como também o Carlos Gentile [de Mello] ${ }^{89}$. Havia o pessoal que criticava o excesso

88 Hésio de Albuquerque Cordeiro é mineiro de Juiz de Fora, nascido em 22 de maio de 1942. Titulou-se em 1965 na Faculdade de Ciências Médicas da UERJ. Integrou a equipe de fundação do Instituto de Medicina Social, também da UERJ. No IMS, coordenou o Mestrado em Medicina Social e exerceu o cargo de Diretor, entre 1983 e 1985. Foi Presidente da Associação Brasileira de Pós-Graduação em Saúde Coletiva. Membro das equipes de transição do Presidente-eleito Tancredo Neves, entre 1985 e 1988 presidiu o Instituto de Assistência Médica da Previdência Social. Atualmente é Diretor da Faculdade de Medicina da Universidade Estácio de Sá Ver: http:// www.scielo.br/scielo.php?pid=S0102-311X1988000300010\&script $=$ sci_arttext\&tlng =pt (Acesso realizado em 01.08 .2006$)$

89 Carlos Gentile de Mello nasceu em Natal (RN) em 1920. Graduou-se em medicina pela Faculdade de Medicina da Bahia. Transferindo-se para o Rio de Janeiro tornou-se auxiliar de ensino voluntário da Faculdade de Medicina da Universidade Federal do Rio de Janeiro. Foi membro titular do Colégio Brasileiro de Cirurgiões, assessor dos Ministérios da Saúde e do Planejamento, vicepresidente da Associação Médica do Estado do Rio de Janeiro e secretário-geral da Associação dos Hospitais do Rio de Janeiro. Foi, também, autor de vários artigos científicos e de uma igualmente extensa obra como colunista da grande imprensa. Faleceu em 1982. 
de importância dada à atenção primária, segundo eles em detrimento da atenção secundária e terciária. Setores mais progressistas criticavam em parte a proposta, porque a entendiam como uma medicina para pobre, algo de segunda categoria, excessivamente medicalizada. As críticas vinham, portanto, dos setores mais à esquerda aos mais conservadores. Mas, no geral, acho que havia um certo consenso, entre intelectuais e sanitaristas, de apoio à proposta. [...]

Lidar com Recursos Humanos e mobilizar instituições em torno desse tema significava, desde os primeiros anos da cooperação, participar da constituição da Saúde Coletiva como um novo campo. De que maneira a cooperação técnica OpasBrasil atuou neste cenário?

José Paranaguá - O projeto de cooperação técnica da Opas tinha uma atuação visível e uma atuação invisível, sempre. Em 1979, por exemplo, fizemos uma reunião na sede da Opas que se chamou I Reunião sobre Formação e Utilização de Pessoal de Nível Superior na Área da Saúde Pública. Este era o propósito visível da reunião. O invisível era a criação da Abrasco [Associação Brasileira de Pós-graduação em Saúde Coletiva], uma associação civil que iria organizar o pensamento avançado daqueles grupos que, na época, eram chamados de comunistas ou marxistas da saúde pública. [...] Todas as pessoas que trabalham nas instituições fazem política a vida inteira, e nós também fazíamos. Foi este o motivo da minha decisão de não trabalhar na Opas fora do Brasil e do meu interesse em atuar sempre aqui.

Cesar Vieira - Nós tínhamos uma aliança muito forte com os grupos brasileiros. Estivemos na criação da Abrasco. Tínhamos que preparar uma delegação brasileira para ir a uma reunião da Alames, a Associação Latinoamericana de Medicina Social. Estávamos recrutando o pessoal, identificando nomes e começamos a discutir: por que não criamos uma associação aqui? Foi circulando essa idéia que ajudamos a criar a associação.

Este movimento teve, por certo, implicaşões entre as secretarias estaduais de saúde $e$ as universidades. Como foi esse processo?

José Paranaguá - As experiências que nós do grupo tivemos com os projetos de integração docente-assistencial, com a redação de documentos, com a realização de eventos em torno desse tema, o projeto de criação das residências em medicina preventiva, a avaliação e o estudo das escolas médicas 
nos levaram a perceber que precisávamos pensar em uma instância operacional para essa relação entre academia e serviços. E a proposta, implantada a partir de 1985 com muito sucesso, e com base na acumulação realizada nesse período, foi a dos núcleos de saúde coletiva.

José Roberto Ferreira - Quando Hésio Cordeiro assumiu a Previdência Social, em 1985, levou o Paranaguá para coordenar a área de recursos humanos, que mobilizava recursos financeiros da Previdência Social para promover os núcleos de saúde coletiva, em um momento em que também se desenvolviam as residências de saúde coletiva. Mas isso foi feito pela Previdência Social, com a filosofia de trabalho do Ppreps, por causa do Paranaguá. A Opas não tinha um relacionamento formal com o Ministério da Previdência, mas sim com o Ministério da Saúde, por isso a participação foi pequena.

\section{A Opas e cooperação técnica no Brasil parecem ter desempenhado um papel singular no desenvolvimento da pesquisa em RH, como isto se deu?}

José Roberto Ferreira - O Ppreps introduziu algo muito importante, que até então não aparecia nos programas básicos da Opas. Nessa época iniciávamos, em Washington, a idéia de promover pesquisa na área de recursos humanos, que ainda não havia. A pesquisa, até então, estava mais dedicada aos problemas pedagógicos. O Ppreps propôs pesquisa em gestão de serviços de saúde. A primeira vez em que se fala, na Opas, em gestão de serviços de saúde é com o Ppreps. Isso foi definitivamente uma contribuição importante do programa. [...]

A área de recursos humanos estabeleceu três linhas iniciais de pesquisa: a pesquisa pedagógica, a de mercado de trabalho e a de gestão. A primeira era a pesquisa educacional propriamente dita. Em gestão, o que fizemos foi promover projetos de pesquisa de modelos alternativos de gestão, analisando cerca de doze esquemas distintos, com um de nossos residentes, Paulo Seixas ${ }^{90}$,

90 O médico Paulo Henrique D’Angelo Seixas integrou a Coordenação Geral da Política de Recursos Humanos para o SUS do Ministério da Saúde. Atualmente é coordenador de Recursos Humanos da Secretaria Estadual de Saúde de São Paulo e membro do Conselho Nacional de Secretários de Saúde (Conass). 
sob a orientação de Francisco Campos ${ }^{91}$, nosso colaborador no Departamento de recursos humanos na sede da Organização. $\mathrm{Na}$ linha de pesquisa de mercado de trabalho foram realizados estudos em vários países relacionados com os programas de planificação de recursos humanos.

Alberto Pellegrini - Por minha trajetória anterior e pela experiência no Acordo, quando cheguei a Washington para trabalhar na Unidade de Pesquisa em 1986, o setor de recursos humanos era minha referência. A área de pesquisa, que nasceu no grupo de recursos humanos, com Juan César, já havia se tornado uma Unidade independente. Eu tinha muito boas relações com o José Roberto e todo seu grupo, mas não havia vínculos formais. Fizemos várias atividades em conjunto, como aquela série de discussões sobre a crise da saúde pública e as publicações que saíram em torno disso. Foram várias reuniões em diversos locais da América Latina, e nelas trabalhamos juntos, os programas de pesquisa e de recursos humanos.

Roberto Nogueira - Quando fui para a Opas, em 1980, comecei a desenvolver gradualmente o interesse em estabelecer uma ponte entre a pesquisa de recursos humanos e a minha trajetória acadêmica. Foi muito difícil transpor o tema da minha tese, muito histórica e caracteristicamente acadêmica, para um escopo de pesquisa institucional. O que mais se aproximava de um trabalho com interesse institucional era aquele que a Cecília Donnangelo fazia na USP, um estudo de mercado de trabalho - basicamente sobre o mercado médico na região metropolitana de São Paulo — que foi tese de mestrado e doutorado dela. [...] Então entendi que deveria fazer algo similar e comecei a conversar com algumas pessoas. O encontro com André Médici², do IBGE [Instituto Brasileiro de Geografia e Estatística], em 1981 ou 1982, foi fundamental naquele momento. Nós formulamos um plano de estudo sobre força de trabalho em saúde, que consistia em analisar os dados dos

${ }_{91}$ Francisco Eduardo de Campos é médico pela Universidade Federal de Minas Gerais (1974), especializou-se em Saúde Pública, em 1975, e em Medicina do Trabalho, em 1976, pela Fiocruz. Pela FGV-RJ, oito anos depois, especializou-se em Política e Administração de Saúde. Realizou seu curso de mestrado em Medicina Social pela Universidade do Estado do Rio de Janeiro (1977), e doutorado em Saúde Pública pela Fiocruz em 1985. Atualmente é Professor da Universidade Federal de Minas Gerais. (Ver Currículo Lattes: http://buscatextual.cnpq.br/buscatextual/ visualizacv.jsp?id=K4783088Y8, consultado em 30/10/2006).

92 André Medici é economista, com mestrado pela Universidade Estadual de Campinas e é doutor em História Econômica pela Universidade de São Paulo. Ocupou diversos cargos públicos no Brasil e foi Presidente da Associação Brasileira de Economia de Saúde. Em 1996 ingressou na Divisão de Programas Sociais do Departamento de Desenvolvimento Sustentável, do Banco Interamericano de Desenvolvimento (BID). Ver: http://www.hospitalar.com/arquivo_livros/ liv711.html (Acesso em 02.08.2006) 
censos de 1970 e 1980 e estudar não só a situação do médico — como fazia a Cecília Donnangelo — mas o mercado de trabalho de todos os profissionais. Isso seguramente teria interesse para o planejamento das políticas de recursos humanos. Começamos então a financiar algumas pequenas pesquisas e estudos de assistência médico-sanitária com base nos censos e fizemos estudos descritivos das forças de trabalho em saúde. [...] Em 1983 publiquei um artigo chamado "A força de trabalho em saúde" na Revista de Administração Pública, que introduzia uma abordagem de economia política mas também demográfica da questão. [...] Foi então que fomos formando um grupo, que contou com Sábado Nicolau Girardi ${ }^{33}$ e Maria Helena Machado ${ }^{94}$, e começamos a formular, com algumas pessoas da Ensp, uma linha de pesquisa sobre força de trabalho em saúde. Mais adiante, os estudos realizados por nós substanciariam, inclusive, o Cadrhu, iniciado em 1987.

A pesquisa em recursos humanos não era um tópico oficial do programa da Opas. Eu a fazia simultaneamente a outras atividades e fui ganhando reconhecimento. Também não envolvia muitos recursos e eu pude abrir esse espaço [...]. Era novidade demais, algo que não parecia ter aplicação imediata.

Uma coisa importante a destacar dessa linha de pesquisa sobre força de trabalho é o fato de ela ter ganhado uma certa evidência continental. Depois, em várias oportunidades, a Opas começou a estimular pequenos estudos nessa linha, apesar das dificuldades com a falta de informação censitária, porque nem todos os países dispõe do que nós temos, em termos de censo, de Pnad Pesquisa Nacional por Amostras de Domicílios] etc. [...] Mas mesmo assim houve interesse na concepção do estudo.

93 Sábado Nicolau Girardi graduou-se em Medicina pela Universidade Federal de Minas Gerais (1981), realizou curso de Especialização em Desenvolvimento de Recursos Humanos pela Escola Nacional de Saúde Pública/FIOCRUZ, em 1984. É também especialista em Medicina Preventiva e Social pela Universidade Federal de Minas Gerais (1983) e foi residente em Saúde Internacional pelo Programa de Formação em Saúde Internacional da Organização Pan-Americana da Saúde (1992). É pesquisador no Núcleo de Estudos em Saúde Coletiva da UFMG e em 2003 assumiu a Coordenação Geral de Recursos Humanos do Ministério da Saúde. Ver: Currículo Lattes em: http://buscatextual.cnpq.br/buscatextual/visualizacv.jsp?id=K4787146T6\#Formacaoacademica/ Titulacao (Acesso em 02.08.2006).

94 Maria Helena Machado é socióloga pela Universidade Federal de Minas Gerais (1980), com mestrado em Ciência Política pela Universidade Federal de Minas Gerais (1982). Doutorou-se em Sociologia pelo Instituto Universitário de Pesquisas do Rio de Janeiro (Iuperj), em 1996. É pesquisadora titular da Escola Nacional de Saúde Pública, onde ingressou em 1986. Nesta instituição foi Coordenadora de Ensino e Pós-graduação e do Núcleo de Estudos em Recursos Humanos, entre outras funções. Foi Subsecretária de Recursos Humanos da Secretaria de Saúde do Estado do Rio de Janeiro. No Ministério da Saúde é Coordenadora Geral da Câmara de Regulação do Trabalho em Saúde e do Fórum Permanente Mercosul, Diretora Técnica em Gestão em Saúde, entre outras atividades. Ver Currículo Lattes: http://buscatextual.cnpq.br/buscatextual/ visualizacv.jsp?id=K4781006P8 (Acesso em 02.08.06). 


\section{Qual avaliação pode ser feita acerca dos resultados da cooperação?}

Carlyle Guerra de Macedo - Vamos considerar dois momentos. O primeiro, aquele em que estávamos envolvidos com o projeto. Tínhamos consciência de que estávamos propondo muito mais do que era possível realizar, mas éramos muito entusiasmados. Achávamos que a idéia era uma semente que iria germinar. Em algumas partes acreditávamos que haveria muito progresso. Uma delas era a da formação de ensino médio, sobretudo dos cursos para o pessoal de enfermagem, a parte liderada pela Izabel. Nós tínhamos esperança de que era uma das áreas que iriam adquirir auto-sustentação com o tempo. E não estávamos sozinhos nessa convicção, tanto é que a Fundação Kellogg, depois, tomou essa parte para si e continuou trabalhando nela.

Já o processo de integração docente-assistencial, como eixo definidor dos currículos nas escolas de medicina, nós tínhamos dúvidas se iria pegar. Ao final, quando eu estava me afastando, depois do Prev-Saúde, havia um gosto amargo da certeza de que isso nunca ocorreria, porque a Universidade é talvez a instituição mais conservadora da sociedade e não mudaria a si mesma. Muito liberal para fora, mas para dentro extraordinariamente conservadora. Mas hoje sou mais tolerante. Acho, inclusive, que esse conservadorismo extremo das universidades e das instituições docentes em geral é bom, porque ajuda a preservar uma memória e evita saltos que podem ser destrutivos, em um mundo em que já não há revoluções. Talvez em uma época em que as revoluções eram possíveis isso tenha sido ruim, mas hoje, quando as revoluções são pura utopia, uma dose de conservadorismo talvez seja bom. Então, naquela época, sabíamos que tínhamos fracassado no alcance das metas, mas que tivemos sucesso em plantar idéias, plantar sementes que, depois, elaboradas noutro contexto, com outros nomes, dariam algum resultado — o que, aliás, é o que sempre acontece. [...]

O Ppreps foi um projeto nacional e com um forte componente executivo, com metas quantitativas precisas, ao contrário da cooperação, que, per se, não tem que alcançar metas em termos finais, mas sim obter transformações nas instituições nacionais para que essas metas sejam atingidas. Esta é uma diferença muito importante. E isso foi mudando: à medida que o Ppreps foi desinflando como projeto nacional e perdendo a perspectiva das metas - pelo menos as quantitativas —, a cooperação passou a existir como tal, propriamente cooperação. Tratava-se então de cooperar com os órgãos para que eles realizassem algo. Por um lado, algo 
se perdeu - a execução propriamente dita das ações—, mas, por outro, ganhou-se um papel mais claro de cooperação.

Alberto Pellegrini - O Ppreps foi um espaço de interação, antes inexistente, dos distintos setores da área da saúde. A Previdência Social era um mundo, a Saúde era outro e o MEC era outro. Hoje, com o SUS, não se imagina como era difícil esse diálogo. O Ppreps criou espaços em que os ministérios podiam dialogar e desenvolver projetos comuns. No caso do Larga Escala, eram o MEC e o Ministério da Saúde trabalhando juntos para a formação de pessoal auxiliar. No caso do Prev-Saúde, era obrigatório que todos participassem, pois nem o Ministério da Saúde podia tocar esse projeto sozinho, nem a Previdência. Foi um projeto que já nasceu interministerial, no âmbito desse espaço do Acordo. Eu acho que isso foi muito inovador.

José Paranaguá - Uma das contribuições mais valiosas da cooperação técnica da Opas como um todo — não só no Brasil — foi o desenvolvimento de um método pedagógico aplicado ao campo da saúde. Essa metodologia, apelidada durante muito tempo de Larga Escala, foi desenvolvida inicialmente para a formação de pessoal auxiliar, o visitador sanitário, que era categoria existente nos serviços públicos de saúde. Depois ela foi redefinida e incorporou a concepção do currículo integrado, com a proposta de um aprendizado que tivesse completa aderência ao processo de trabalho, na qual o trabalhador é aprendiz e é efetivamente reconhecido. [...] E pelo menos na área de recursos humanos da Opas tudo teve a mesma influência, que foi o método desenvolvido pela Izabel.

Por exemplo, a montagem de um curso de especialização de enfermagem em saúde pública, voltado para enfermeiros trabalhando em um sistema descentralizado de saúde, que os capacitasse para a gerência do processo de trabalho e para a gerência de problemas de saúde na comunidade. O curso foi dado na Universidade Federal de Minas Gerais, mas a princípio era um projeto a ser desenvolvido em sete universidades. O problema foi que, das sete instituições, só uma conseguiu chegar ao fim, porque nas outras a tradição e a resistência das instâncias acadêmicas e a cultura da transmissão do conhecimento impediram que o curso chegasse a ser implantado. O Gerus [Gerência de Unidades de Saúde] foi também influência desse modelo, assim como o Cadrhu [Curso de Aperfeiçoamento em Desenvolvimento de Recursos Humanos de Saúde] e vários outros com menor ênfase na integração curricular. [...] 
A minha participação no projeto a e em toda a proposta da cooperação na área de educação técnica foi mais a de apoiar as iniciativas da Izabel. Sempre que ela nos pedia para ajudar em alguma iniciativa que considerava importante nós atendíamos ao seu pedido. Então, eu participei diretamente mobilizando recursos para iniciativas durante a construção do Larga Escala. [...]

IZABEL DOS SANTOS - Acho que o ensino superior permaneceu intocável. Se há alguma experiência nesse sentido, eu desconheço. Todavia, alguns cursos de pós-graduação lato sensu tiveram seu embasamento a partir da concepção do movimento Larga Escala. Como por exemplo, o Curso de Especialização em Saúde Pública da Universidade de Minas Gerais, o Curso de Especialização em Desenvolvimento de Recursos Humanos (Cadrhu), e o Curso de Especialização em Gerência de Unidades Básicas (Gerus). Mas, de novo, ressalto, a graduação continuou intocável, assim como a pós-graduação stricto sensu. [...]

A paixão pelo Larga Escala me deu a gana de continuar persistindo por vinte anos. Acho que ninguém sabia o quanto eu estava apaixonada por esse trabalho. No entanto eu estava e sabia que ele não estava pronto, por isso era necessário continuar persistindo.

Danilo GARCia - Na área de enfermagem, eu tenho a impressão que muita coisa se fez, graças à participação da Opas. Aliás, onde eu digo Opas, leia-se Izabel [dos Santos]. O Larga Escala, esse projeto,... a Izabel se debruçou nisso, e com uma inteligência de criar, nos locais, verdadeiros fanáticos pela proposta. Então, o Larga Escala virou um cartão de visita. Os ministros faziam referência. Agora, dizer que isso tenha sido mérito da Opas.... O mérito da Opas foi acolher a Izabel e respaldá-la [...]. O Larga Escala foi, nada mais, nada menos, que a integração docente assistencial pra valer. $\mathrm{E}$ a Izabel acionava a coisa daqui de Brasília. Ela acionava, botava a meninada nos estados a funcionar. Então, o mérito da Opas nesse negócio foi não atrapalhar.

Além dos resultados alcançados no Brasil, que tipos de desdobramentos ocorreram nos demais paises da América Latina e do Caribe?

Roberto Nogueira - Eu acho que não houve repercussão da experiência brasileira em outros países. O Brasil tem uma posição muito específica para a Opas, porque é considerado privilegiado por várias razões, sobretudo 
porque tem mais recursos. O país tende a ser visto como o primo rico, tem todas as condições de fazer o que bem entende, então nunca é exemplo para os outros. Nossas condições institucionais, políticas e financeiras são excepcionais. Por isso a Opas parece ter o cuidado de não colocar o Brasil como exemplo ou paradigma para os outros países. É preferível pegar as iniciativas de outros países com condições mais niveladas em relação à América Latina.

José Paranaguá - A Opas vive um problema recorrente que é o dilema entre praticar cooperação técnica e assistência. A diferença entre uma e outra é que cooperação técnica significa estabelecimento de relações de intercâmbio, de mobilização de conhecimento e experiências realizadas nos países. Diversas iniciativas da Opas têm apontado nesse sentido. A experiência brasileira, esta de que estamos tratando, talvez seja a mais duradoura e radical de cooperação técnica. [...] Por ter sido um projeto bem-sucedido de cooperação, os consultores ou a direção da organização poderiam explorá-la melhor e utilizar os recursos nela desenvolvidos para o fortalecimento de relações com outros países. Ou seja, devia-se estender a experiência da cooperação técnica no Brasil para o universo dos 36 países membros da organização que têm problemas muito semelhantes, respeitados os contextos histórico-culturais de cada um deles. [...]

Por exemplo, a proposta do currículo integrado. Como se muda o processo de trabalho através de uma experiência pedagógica? Porque na experiência pedagógica do currículo tradicional, ou da pedagogia baseada na transmissão do conhecimento, o produto desse processo é o próprio conhecimento. "Eu sei mais do que antes do curso; adquiri um elenco de conhecimentos que não tinha antes dele". No currículo integrado muda-se o processo de trabalho, instaura-se uma nova relação entre as pessoas da equipe, alteram-se os instrumentos e equipamentos de trabalho. O segredo do currículo integrado é este: organizar um processo que inclua tudo isso. O Gerus, por exemplo, é um curso em que está embutida toda uma estruturação do papel de vigilância à saúde, de responsabilidade pública com a saúde, da rede de unidade de saúde do município. Ou ele é entendido desse jeito ou é só mais um cursinho. E nós desenvolvemos essa metodologia e a aplicamos de forma sistemática para a formação de técnicos de nível médio, que é adotado hoje, inclusive, pelo Profae, nas escolas técnicas.

Cesar VIEIRA - Uma organização feito a nossa, que consegue atrair e manter o Paranaguá no quadro há mais de 20 anos, ou que manteve a Izabel 
dos Santos, do Brasil, o Edmundo Granda ${ }^{95}$, do Equador, e outros dos demais países, tem uma experiência muito positiva. Foram pessoas precursoras que conseguiram, mesmo sendo nacionais, trabalhar a dimensão internacional e vice-versa. É uma vivência que os estrangeiros não têm, porque há uma barreira natural ou um limite para a sua inserção. Por ter participado dessa equipe há vinte e tantos anos, eu acho que isso foi ótimo para a organização, e agora, por uma série de medidas, tende-se a cortar esse tipo de experiência. [...]

\section{Considerando as experiências brasileira e latino-americana, qual o futuro de organismos como a Opas como agências de cooperação interamericana?}

Carlyle Guerra de Macedo - A Opas é, ao mesmo tempo, uma das organizações mais centralizadas e descentralizadas. É centralizada no sentido de que todo o poder, nela, depende do diretor. Ele é a única autoridade eleita e, teoricamente, tem a prerrogativa de organizar a secretaria da maneira como melhor lhe convier. Posto isso em termos de autoridade formal, há todas as limitações da realidade. Para se entender essas relações entre Opas e os países, entre os programas da Opas central e os programas de países apoiados por ela, é preciso ter sempre em mente a diferença entre a organização e a secretaria. A secretaria é composta de pessoal contratado para trabalhar na Opas e é dirigida pelo diretor. A organização são os países, ou melhor, os governos que os representam. As pessoas nunca recordam essa diferença, mas ela é importante do ponto de vista de filosofia da organização e também do ponto de vista da ação.

O diretor deve, em princípio, responder às decisões da Organização que são tomadas pelos países, tanto coletivamente, nos conselhos, nos chamados corpos diretores ou em cada país individualmente, no que se refere as ações em seu território. Daí a Opas não se definir como um organismo internacional, mas sim intergovernamental. Durante o meu período como diretor, eu sempre insistia com o pessoal sobre esse aspecto, porque há uma diferença imensa. As organizações internacionais respondem às nações. Estão, assim,

95 O equatoriano Edmundo Granda é professor no mestrado de Saúde Pública na Universidade Nacional de Loja, Equador. Autor de extensa obra sobre aspectos teóricos e metodológicos em epidemiologia e saúde, integra a equipe da representação da Opas em Quito, Equador, onde atua na área de recursos humanos em saúde e no Projeto Técnica de Informação e Gestão do Conhecimento. 
além - e às vezes sobre - os governos. A reunião de nações confere um poder extraterritorial que é superior aos governos. Mas isso não existe, e não sei se alguma vez existiu — talvez apenas às vezes algo assim ocorre no Conselho de Segurança das Nações Unidas. Então, como organização intergovernamental, a Opas responde a governos, no caso representados pelos ministérios da Saúde, porque os ministros dessa pasta são os delegados dos governos nos corpos diretores da Organização.

Nessa perspectiva a Opas continuará a existir, limitada em sua ação pelas decisões dos governos membros, a capacidade de sua secretaria e liderança de seu diretor.

Alberto Pellegrini - A história da cooperação internacional em saúde transita da assistência técnica - na qual o consultor levava consigo o conhecimento aos países - à administração do conhecimento, defendida pela primeira vez como missão primordial da Opas na gestão do Carlyle e entendida como a capacidade de promover a geração, seleção, avaliação, disseminação e utilização do conhecimento. $\mathrm{Na}$ época, colocar a administração do conhecimento como missão primordial da Organização foi algo muito avançado, quase uma ruptura, mas hoje me parece obsoleta a idéia de dar a Opas o papel do protagonista que seleciona, avalia, dissemina e promove a utilização do conhecimento. Na nova cooperação, as redes são os atores principais, e cabe a Organização basicamente criar espaços de interação. Pode-se promover redes como a ScienTI Rede Internacional de Fontes de Informação e Conhecimento para a Gestão de Ciência, Tecnologia e Inovação] e seus nós estarão nos países. Por isso vejo o grande potencial da BVS [Biblioteca Virtual em Saúde], não apenas como depositária de conhecimentos e informações, mas especialmente como um espaço de interação entre grupos. É claro que a Opas é também um ator importante no âmbito desse espaço. Mas se você me perguntar, hoje, o que é cooperação técnica, eu respondo: cooperação técnica é fundamentalmente a criação de oportunidades e espaços de interação. [...]

José Roberto Ferreira - A organização identifica núcleos de grande desenvolvimento, dá a eles caráter internacional, mas só contribui com o aporte financeiro de algum componente específico de cooperação técnica. O processo para sua aprovação é muito complexo e lento [...]. Paralelamente, a Opas criou um outro mecanismo que é o TCC [Cooperação Técnica entre Países], um intercâmbio entre nacionais visando a cooperação. $\mathrm{O}$ acordo tem de ser aprovado por representantes dos dois países envolvidos, e o financiamento é 
feito com os recursos da Opas destinados aos países, em partes mais ou menos iguais. Este também é um processo muito lento, mas é um dos mecanismos de cooperação existentes hoje. Depois vieram as redes, até agora com poucos resultados, e é nesta fase que nos encontramos. Atualmente buscamos mecanismos que permitam aos grupos nacionais em rede participar mais do processo decisório.

José Paranaguá - Está se fazendo aquilo que o momento requer. Conforme eu previ, hoje há uma grande autonomia das instituições nacionais em relação à cooperação técnica da Opas. Já temos gente no país que participou de seminários e outros processos de discussão, promovidos ou não pela Opas, e o ministério e outras instituições podem formular seus projetos sem a participação direta da organização. O que o ministério preserva é o interesse pela participação da Opas do ponto de vista institucional, em virtude da legitimidade e do reconhecimento científico e político que ela tem. Hoje não vejo necessidade de consultoria de um especialista da Opas, minha ou de qualquer de meus colegas de Washington, nos projetos que são promovidos pelo ministério. [...] A proposta em que estamos empenhados agora é a de estender para as dezenas de instituições da América Latina as redes de cooperação que ajudamos a formar, no Brasil, em 30 anos de experiência. Por isso há alguns anos nosso programa não é mais de recursos humanos, mas sim de cooperação em redes colaborativas. [...]

Mudar do modelo de assistência técnica para um modelo que mobilize centros de referência dos países para cooperação técnica é a proposta em pauta na Opas. Esperamos agora que ela seja assumida pela diretora da organização em termos administrativos e práticos, porque do ponto de vista político isso já foi feito. No discurso de posse e em reuniões com os gerentes da organização, que são os representantes e os coordenadores de programas na sede em Washington e nos países, a diretora vem afirmando que a linha de trabalho que ela quer fortalecer, na Opas, é a da cooperação técnica, da cooperação descentralizada com base em países.

Cesar Vieira - Minha conclusão é que ninguém sabe sobre o total de interfaces das relações Opas-Brasil, porque é um processo multiporoso e muito complexo. $\mathrm{Na}$ Assessoria Jurídica da Opas, supostamente, todos os convênios estão registrados. Mas em conversa com alguém, de outra área, pode-se saber sobre um projeto com uma secretaria estadual que não está em nenhum desses convênios. As relações atuais são múltiplas. É impressionante. 
José Roberto Ferreira - A idéia de que a Opas tem algo especial para aportar aos países é do início do século, quando a organização foi criada e os países não tinham competência própria. A organização estava mais em contato com o primeiro mundo e oferecia transferência de tecnologia. A ação era essencialmente supletiva. À medida que os latino-americanos ganharam cada vez mais competência, passou a ocorrer um intercâmbio horizontal entre eles, um apoio mútuo. Nesse sentido, acho que uma maior participação no processo decisório das próprias instituições colaboradoras é melhor do que contar com decisões tomadas por ministros que, afastados do que está ocorrendo, definem prioridades que na realidade não o são.

Na década de 70, ao participarmos da formulação do plano de ação da OMS no campo de Recursos Humanos, chamamos a atenção para a possibilidade de utilização dos mecanismos de redes de cooperação, tomando como exemplo alguns programas da região das Américas, como o caso da Bireme, interligada com bibliotecas de saúde em toda a região; o programa de saúde materno-infantil, com unidades em vários países; o próprio Ppreps, com a rede de unidades estaduais de planejamento e gestão de recursos humanos, interapoiando-se com a ajuda do núcleo central e das demais unidades estaduais etc. Entre as vantagens das redes está a possibilidade de usufruir de várias experiências, aproveitando em cada caso os aspectos que melhor correspondem a situação específica de cada um de seus membros. Em especial poderá beneficiar-se por este mecanismo o desenvolvimento da pesquisa científica e aplicada, que em cada caso possa absorver cada país. Este mecanismo tende a se generalizar com a possibilidade de utilização de modernos recursos de comunicação eletrônica.

No tocante, em particular, ao tema de recursos humanos, quais são os horizontes?

Roberto Nogueira - Acho que a Opas-Brasil praticamente perdeu a sua potencialidade de afetar as políticas de recursos humanos. Talvez eu tenha essa impressão porque não conheço as outras áreas, mas penso que provavelmente ela irá se resumir a um papel de assessoria técnica, muito especializada, muito pontual. Eu, por exemplo, tenho essa vivência atualmente, no Ipea. Acabei de fazer um estudo com outras pessoas do Ministério da Saúde, sobre os objetivos do milênio acerca de mortalidade materno-infantil, com aspectos demográficos, epidemiológicos e avaliação de políticas de saúde. Nós o enviamos à Opas para que eles leiam e façam sugestões, contribuições pontuais ao 
texto. Mas não farão, no contexto político atual, a avaliação das políticas do milênio. No Brasil isso não acontece. É o Ipea, junto com os outros ministérios - porque são vários e grandes os objetivos do milênio — que está fazendo essa avaliação.

Eu dei esse exemplo para mostrar que o papel da Opas, hoje, já não é de protagonismo político, mas de assessoria técnica especializada e pontual. Antigamente o Cesar Vieira dizia, brincando, que cada programa especial tinha o seu assessor da Opas. Era o companheiro ali, o tempo todo junto, a ponto de, no dia-a-dia, os papéis se confundirem. Então minha impressão é que, hoje, a Opas se restringe a um papel mais a distância, mais de opinião e não de formulação. [...] Hoje ela enriquece o processo com informações, análises, produtos mais ou menos desenvolvidos do ponto de vista de referencial teórico. Tanto é assim que o Paranaguá vem se dedicando em grande medida à questão dos sistemas de informação, com ênfase na questão da web. Ele não tem mais uma função de formulação. $\mathrm{E}$ isso ficou ainda mais claro neste último governo.

[...] A Opas já entendeu que a autonomia brasileira está mais do que consagrada desde o final dos anos 1980 e começo dos 1990. Seu papel aqui é de contribuições esporádicas, de centro de informação e reunião, uma função talvez mais diplomática do que propriamente política, no sentido de ajudar tecnicamente a formulação de política. Mas ainda é uma referência. As reuniões que o ministério faz reunindo grupos do país inteiro acontecem na Opas, que as apóia.

José Roberto FErreira - Houve força e apoio importante do governo no sentido de desenvolver o Observatório de Recursos Humanos. Em geral este parece ser um tema periférico nos ministérios de saúde da América Latina, porque na maioria dos países, com exceção de Cuba e, ultimamente, do Brasil — que vem se atualizando nessa linha—, esses órgãos estão afastados da programação de recursos humanos, que fica a cargo dos ministérios de educação. Sem o apoio direto do governo e sem motivação para criar algo nessa área, os outros pá́ses são muito fracos no desenvolvimento do Observatório. Talvez não tenha havido ainda, por parte de Washington, uma sistematização do trabalho de modo que um país pudesse cooperar com outro e desenvolver um trabalho colaborativo. 
José Paranaguá - Todo problema que não tem dono permanece sem solução, e é este o caso da pesquisa em recursos humanos. E como isso reflete na academia? Nega-se o valor da pesquisa em recursos humanos porque é um problema cuja solução ninguém quer assumir. [...] Mas o cenário está mudando. Em termos caricaturais, há vinte anos a afirmação era: "Eu sei como resolver o problema de recursos humanos" — todo mundo sabia, qualquer ministro ou secretário de saúde. Há dez anos a situação mudou por completo, e a afirmação passou a ser: "Não sei e tenho raiva de quem sabe." Hoje estamos em uma terceira etapa - a exemplo do trabalho da Segetes [Secretaria de Gestão do Trabalho e da Educação na Saúde, do Ministério da Saúde] com os Observatórios: "Eu não sei a solução, mas quero colocar a discussão na praça."

$\mathrm{Na}$ área de pesquisa eu participei de algumas iniciativas, como a preparação de docentes para o chamado de Módulo Dois do antigo Cadrhu, um módulo sobre pesquisa em recursos humanos. Por último, o projeto Observatório, que é a idéia de criar capacidade de investigação, promover a interação científica entre pares e, ao mesmo tempo, envolver atores sociais que não são do campo científico para fortalecer e conferir legitimidade científica, política e técnica à área de recursos humanos. Com o projeto da Rede Observatório de Recursos Humanos, acho que estamos concluindo um ciclo de iniciativas. 


\section{Resenhas Biográficas}

\section{Alberto Pellegrini Filho}

Alberto Pellegrini nasceu em São Paulo, capital, em 18 de abril de 1944. Ingressou na Faculdade de Medicina da Universidade de São Paulo no ano de 1963, diplomando-se em 1968. Ele iniciou sua residência médica no Departamento de Neuropsiquiatria (Divisão de Neurologia) do Hospital das Clínicas da Universidade de São Paulo, onde concluiu a residência em 1977.

Personagem ativo na vida política e acadêmica da Faculdade, Pellegrini, em pleno período de ditadura militar, acompanhou o movimento estudantil médico, em especial as Semanas de Estudos sobre Saúde Comunitária (Sesacs). Estes eventos, com forte componente de crítica política, foram palco de discussão de temas da área de saúde presentes na agenda das elites médicas nacionais e continentais, como, por exemplo, o debate acerca da necessidade de elaboração de programas de extensão de cobertura, baseados na experiência da medicina comunitária e da medicina simplificada.

A sua vida profissional teve início nas atividades como professor-assistente no Departamento de Neurologia da Faculdade de Ciências Médicas da Universidade Estadual de Campinas (Unicamp) no ano de 1971. Em agosto de 1976 concluiu o Doutorado em Ciências pela Unicamp, defendo a tese "Contribuição ao estudo da crotamina no músculo esquelético", tornando-se professor-assistente-doutor. 
Em 1978 foi aprovado por concurso para o cargo de pesquisadoradjunto na Escola Nacional de Saúde Pública (Ensp/Fiocruz). Em 1979, foi aprovado para o cargo de Professor do Departamento de Medicina Preventiva e Social, da Faculdade de Medicina da Universidade Federal de Minas Gerais. A partir de 1986, passou a exercer o cargo de Consultor Regional da Opas para os temas de Ciência e Tecnologia em Saúde, passando a residir em Washington.

$\mathrm{Na}$ Ensp/Fiocruz, coordenou durante um ano, a partir de janeiro de 1977, o projeto de investigação "Medicina de Comunidade", do Programa de Estudos Sócio-econômicos de Saúde (Peses). Em decorrência de sua experiência no Peses, foi, em 1978, designado consultor da Secretaria Técnica do Programa de Interiorização das Ações de Saúde e Saneamento (Piass), do Ministério da Saúde. Na mesma época, atuou como assessor do Ministro da Previdência e Assistência Social (MPAS), junto à Secretaria de Serviços Médicos.

Sua formação acadêmica e experiências profissionais, especialmente voltadas para questões relativas à ciência e à tecnologia em saúde levaram-no em 1979, ao Programa de Desenvolvimento de Recursos Humanos para a Saúde no Brasil, a denominação então assumida pelo Programa de Preparação Estratégica de Pessoal de Saúde (Ppreps), instaurado pelo acordo de cooperação técnica entre a Opas e os ministérios da Saúde e da Educação iniciado em 1975.

A passagem da década de 1970 para a de 1980 registra, exatamente, a ampliação das propostas e pretensões da cooperação técnica estabelecida em meados dos anos 1970. Personagem dessa segunda etapa do Ppreps, Pellegrini seria fundamental para a elaboração do Programa Nacional de Serviços Básicos de Saúde (Prev-Saúde), quando se procurou considerar tanto a ampliação da cobertura dos serviços de saúde nas periferias urbanas, quanto a relação entre os serviços de saúde públicos e aqueles controlados pela iniciativa privada, então em franco processo de expansão.

Pellegrini participou dos primeiros movimentos de organização da VIII Conferência Nacional de Saúde, realizada em Brasília, no ano de 1986, um evento decisivo na história do movimento sanitário e da saúde no Brasil. Antes da realização da Conferência, porém, dirigiu-se a Washington para ocupar o seu posto de funcionário concursado da Opas, função que exerceu até 1989. Nesse ano assumiu o posto de Coordenador do Programa de Pesquisa e Desenvolvimento Tecnológico da Organização, que ocupou até 2004, ano em 
que se aposentou. Em março de 2006 assumiu a coordenação da Comissão Nacional sobre Determinantes Sociais da Saúde.

Sua vida acadêmica concentrou-se nas áreas de Didática e Psicologia da Aprendizagem, Saúde Pública, Metodologia da Pesquisa e Aprendizagem, e Planejamento e Administração de Ciência e Tecnologia. Pellegrini publicou trabalhos no Brasil e no estrangeiro sobre estudos de patologias clínicas, medicina comunitária, residência médica, serviços de saúde, saúde coletiva, indicadores técnico-científicos em saúde, C\&T em saúde, gestão do conhecimento em saúde, políticas de saúde e cooperação técnica, entre outros temas.

\section{Carlyle Guerra de Macedo}

Carlyle Guerra de Macedo nasceu em Parnaguá, no estado do Piaú, em 15 de abril de 1937. Graduou-se em medicina pela Faculdade de Medicina da Universidade Federal de Pernambuco em 1961. Recém-formado, foi para o Chile, onde realizou curso de Planificação de Saúde, no Instituto Latino-Americano de Planificação Econômica e Social (Ilpes). Em 1964, freqüentou o Curso de Capacitação em Técnicas de Desenvolvimento Econômico, organizado pela Superintendência de Desenvolvimento do Nordeste e pela Comissão Econômica para o Progresso da América Latina (Sudene/Cepal). Em 1967, o médico participou do curso e do seminário sobre Administração de Saúde e Comunicações na Universidade da Carolina do Norte e na Universidade de Pittsburgh, ambas nos Estados Unidos. Em 1968, Carlyle complementou sua formação com a licenciatura em Saúde Pública na Universidade do Chile e com o curso sobre Dinâmica da População no Centro Latino-americano de Demografia (Celade), na Universidade do Chile.

Dedicou-se ao magistério especialmente nas escolas de Saúde Pública da América Latina, entre elas a Escola de Saúde Pública da Universidade do Chile, a Faculdade Nacional de Saúde Pública da Colômbia, a Escola Nacional de Saúde Pública do México, Escola Nacional de Saúde Pública do Peru e na Escola de Saúde da Universidade de Buenos Aires. Foi consultor e instrutor do Instituto Latino-Americano de Planificação Econômica e Social (Ilpes) em 1969 e, entre 1970 e 1975, chefiou a Divisão de Adestramento do Centro PanAmericano de Planificação da Saúde, ambos os postos em Santiago, Chile.

No Brasil, ainda como um jovem médico, Carlyle Guerra de Macedo foi coordenador do Projeto de Colonização do Maranhão e responsável pela 
organização e chefia da Divisão de Saúde no Departamento de Recursos Humanos, da Superintendência de Desenvolvimento do Nordeste (Sudene) entre 1962 e 1963. Ele organizou a Secretaria de Saúde do Estado de Piauí, onde implementou o Primeiro Plano Estatal de Saúde (1965-66). Neste posto permaneceria durante os anos de 1966 a 1970. Foi também membro do Conselho de Desenvolvimento, no mesmo estado, durante o período 1966-1969. Em âmbito nacional, Carlyle coordenou, entre 1975 e 1983 o Programa de Preparação Estratégica de Pessoal de Saúde (Ppreps), fruto do acordo de cooperação técnica entre a Opas e os ministérios da Saúde e da Educação do Brasil. Neste período dirigiu o Programa Nacional de Serviços Básicos de Saúde (Prev-Saúde), integrou o Conselho Nacional de Saúde, o Conselho de Recursos Humanos do Programa Nacional de Alimentação e Nutrição.

Em sua gestão no Ppreps, merece destaque o esforço rumo a uma descentralização dos serviços de saúde, particularmente no que diz respeito à formação de pessoal auxiliar de saúde. A partir de finais dos anos 1970 o programa experimentou ampliação dos seus temas e objetivos, o que permitiu a Carlyle Guerra de Macedo desempenhar um importante papel nos debates e esforços para a implementação de um projeto de ampliação da cobertura dos serviços básicos de saúde no país, como foi o caso do Prev-Saúde.

Em 1983, assumiu a Direção da Opas, em Washington, em substituição a Héctor Acuña, após eleição realizada no ano anterior. Permaneceu no posto durante dois mandatos, até o ano de 1995, quando assumiu George Alleyne. $\mathrm{Na}$ Opas, Carlyle Guerra de Macedo priorizou investimentos na área do ensino de Saúde Pública e na organização de sistemas de expansão de cobertura de serviços de saúde, bandeira levantada pela Organização desde a redação dos Planos Decenais de Saúde a partir dos anos 1960. Nesse quadro, seu esforço também incluiu o desenvolvimento da área da Saúde Coletiva. Além disso, ele foi também vice-presidente da Comissão Mundial Para a Certificação da Erradicação da Poliomielite, da Organização Mundial da Saúde (OMS).

Como diretor da Organização, desenvolveu um conjunto de políticas destinadas a promover a atenção básica de saúde, estimulando o fortalecimento das infra-estruturas dos serviços de saúde de âmbito nacional e local e afirmando a relação entre saúde e desenvolvimento econômico e social. Dedicou especial atenção aos temas da informação e da gestão de conhecimento em saúde e, particularmente na América Central, sob o lema 
"Saúde, uma Ponte para a Paz", em um período de profunda instabilidade política, a Opas fortaleceu a presença como agência intergovernamental de saúde na região.

Carlyle Macedo publicou trabalhos sobre cooperação técnica, preparação de pessoal de saúde, perspectivas e rumos da saúde mundial, perspectivas da epidemiologia e o papel da Opas. Com base em registros de conferências e discursos que proferiu, pode-se contabilizar mais de 120 textos elaborados. É filiado a várias associações médicas na América Latina e é Presidente Honorário do Colégio Interamericano de Médicos e Cirurgiões. Por sua atuação, foi laureado com condecorações e prêmios na Guatemala, Peru, Colômbia, Bolívia, Honduras, Cuba, Venezuela, Estados Unidos, Espanha e Brasil. Atualmente ele é Diretor honorário da Opas.

\section{Cesar Vieira}

Mineiro, Cesar Vieira é natural de Belo Horizonte, onde nasceu a 25 de agosto de 1945. Concluiu o curso de medicina na Universidade Federal de Minas Gerais em 1968. Recém-formado dirigiu-se a São Paulo onde realiza seus estudos de especialização (1970) e mestrado (1972) na Faculdade de Saúde Pública da Universidade de São Paulo. Em 1981 concluiu um segundo curso de mestrado, na Universidade de Sussex, Inglaterra, na área de estudos de desenvolvimento.

Já formado, Vieira foi médico de campo na Campanha de Erradicação da Varíola no Estado de Minas Gerais, desempenhando esta função até 1970. No ano seguinte inicia as atividades docentes, primeiro como auxiliar de ensino e depois como professor assistente de medicina social, no Departamento de Medicina Preventiva e Social da Faculdade de Medicina da UFMG. Nesta mesma época atuou junto a Assessoria de Planejamento e Coordenação da Secretaria de Saúde de Minas Gerais, exercendo a função de Assessor Chefe entre 1975 e 1976.

Neste ano ingressou no Grupo Técnico Central da cooperação OpasBrasil. Em 1979 concluiu o seu o primeiro período de atuação junto ao Programa de Preparação Estratégica de Pessoal de Saúde (Ppreps), ano em que inicia seus estudos no exterior. No seu retorno ao país, no início dos anos 1980, Vieira retoma as suas atividades junto à cooperação. Em finais de 1983, em substituição a Roberto Passos Nogueira - que por seu turno sucedera a 
Carlyle Guerra de Macedo -, Vieira assumiu a coordenação executiva da cooperação, exercendo-a até 1985.

A segunda metade da década de 1985 marca o início da longa carreira internacional de Vieira junto aos escritórios centrais da Opas em Washington. Entre 1985 e 1986, Vieira foi Assessor da Coordenação de Planejamento Estratégico. De 1986 até 2003 foi Coordenador do Programa de Políticas Públicas e Saúde. Por fim, entre 2003 e 2005, exerceu a função de Chefe da Unidade de Estratégias e Políticas. Entre os temas que mereceram a sua atenção durante este período se incluem: saúde e redução da pobreza; globalização, integração regional, comércio e saúde; equidade em saúde; economia e financiamento da saúde; reforma setorial e desenvolvimento de políticas e etnicidade em saúde.

Cesar Vieira publicou trabalhos nas revistas da Opas, periódicos especializados norte-americanos e latino-americanos, especialmente sobre os temas das desigualdades, globalização e equidade em saúde e saúde desenvolvimento. É autor de vários documentos técnicos de caráter políticoprogramático em saúde internacional.

Aposentou-se pela Opas em 2005 e desde então atua como consultor.

\section{Danilo Prado Garcia}

Danilo Prado Garcia nasceu em São Simão, São Paulo, em 28 de novembro de 1931. Realizou o curso médico na Faculdade de Medicina da Universidade de São Paulo (FMUSP), concluído em 1951. Sua carreira profissional se iniciou como clínico e cirurgião na Cidade de São João da Boa Vista, interior paulista.

No início dos anos 1960, voltou a São Paulo, onde retoma estudos de laboratórios e cirurgia experimental. Nesse período concluiu o doutorado em Cirurgia na FMUSP, onde também passou a lecionar até 1975. Simultaneamente, Prado Garcia organizava o Serviço de Clínica e Cirurgia do Aparelho Digestivo no Hospital São Camilo. O trabalho considerado inovador neste estabelecimento privado, onde organizou equipe polivalente e multidisciplinar, incorporando estudantes de graduação, internos e residentes, com atenção para a Saúde Pública, foi o passaporte para o seu ingresso no Programa de Preparação Estratégica de Pessoal de Saúde (Ppreps), iniciativa dos Ministérios da Saúde e da Educação com a Opas. 
Em 1978, financiado por uma bolsa concedida pela Organização Mundial da Saúde (OMS), Danilo Garcia foi para Paris, onde realizou, na Universidade de Paris I (Panthéon-Sorbonne), programa de estudos em Economia para a Saúde equivalentes a um mestrado.

Em 1982, de volta ao Brasil, Danilo se integra à equipe de Administração de Saúde Previdenciária no Ministério da Previdência e Assistência Social, ao final da gestão de Jair de Oliveira Soares. Em 1984, Danilo se integra novamente a Opas, cumprindo diversas tarefas no Brasil, na Bolívia, no Uruguai e na Argentina. Em 1988, deixa a Opas e incorpora-se à Fundação Faculdade de Medicina, da FMUSP, onde foi Diretor da Fundação do Fígado, mantenedora do Instituto do Fígado.

Em 1991, desligou-se da Fundação para voltar a Paris, onde realizou curso de psicanálise, no Instituto Junguiano. Atualmente, Danilo Prado Garcia é psicoterapeuta.

\section{IZABEL DOS SANTOS}

Izabel dos Santos nasceu em Pirapora, Minas Gerais, em 1927. Formou-se em enfermagem na Escola de Enfermagem Hugo Werneck, atualmente vinculada a PUC/MG, na capital do estado, para onde rumou incentivada por um pároco de sua cidade natal. Formada, retornou a Pirapora para organização do serviço de saúde local, tanto da rede hospitalar quanto da rede básica, contando com apoio do Serviço Especial de Saúde Pública, o Sesp. Logo foi promovida a Supervisora Regional, organizando os serviços hospitalares de São Francisco, São Romão, Januária, implantados no âmbito do Plano Salte, o plano de ação e desenvolvimento do governo Dutra (1946-51), orientado para as áreas de saúde, alimentação e energia.

Dificuldades de ordem política a fizeram rumar, ainda a serviço do Sesp, para Várzea Grande, estado de Mato Grosso, onde ministrou um dos primeiros cursos de formação de auxiliares de saúde. Do estado de Mato Grosso, Izabel se dirigiu para Pernambuco, onde trabalhou na Escola de Enfermagem de Recife, posição na qual enfrentou as vicissitudes do golpe militar de 1964

Nesse mesmo período, no contexto da implantação da Aliança para o Progresso (1961), Izabel foi convidada pela Opas para fazer parte de grupo para discussão de políticas públicas, quando realizou viagens para vários países 
da América Latina. Nesse momento, ela também serviu como membro de comitês de seleção de livros para o Paltex, programa também coordenado pela Organização, a partir da segunda metade dos anos 1960, destinado a publicação e venda subsidiada de publicações didáticas em saúde.

Em meados dos anos 1970, a convite de João Yunes, Chefe de Gabinete do Ministro da Saúde, Izabel se mudou de Pernambuco para Brasília, onde integrou o grupo técnico do Programa de Preparação Estratégica em Formação de Recursos Humanos, o Ppreps, iniciativa fruto de um Acordo de cooperação técnica assinado no ano de 1975, entre o governo brasileiro e a Opas. Nesse programa, Izabel se envolveu, sobretudo, com projetos de formação de pessoal de nível técnico e elementar de saúde. Um dos projetos considerados mais bem sucedidos, nessa área, foi o chamado Projeto Larga Escala, institucionalizado a partir do início dos anos 1980 e que foi responsável tanto pela formação de pessoal técnico e elementar, como também por inovações metodológicas no ensino em saúde.

Nos anos 1995 e 1996, Izabel trabalhou junto a Secretaria Estadual de Saúde do Rio Grande do Norte, onde procurou estimular a participação dos trabalhadores do setor na construção das metas das escolas técnicas, num esforço de permitir maior integração entre o sistema de ensino e o sistema de saúde. Izabel acabou por contribuir diretamente para a implantação do Centro de Formação de Pessoal de Nível Médio no Estado.

\section{José Francisco Nogueira Paranaguá de Santana}

José Paranaguá de Santana nasceu em Campo Maior, Piauí, em 24 de abril de 1950. Filho de professores - seu pai foi professor na Universidade de Brasília (UnB) e sua mãe foi professora normalista - e o mais velho dentre seis irmãos. É casado e pai de Tiago e Diogo. Graduou-se em Medicina pela UnB em 1974, onde também se especializou em Medicina Comunitária (1975) e obteve o título de mestre em Medicina Tropical em 1980.

Recém-formado, Paranaguá trabalhou entre 1975 e 1978 no Projeto Planaltina, na cidade de mesmo nome, no Distrito Federal. Fruto de um acordo entre a UnB, a Fundação Hospitalar do Distrito Federal (FHDF), o Funrural e a Fundação Kellogg, o projeto propunha-se a desenvolver um novo currículo de medicina voltado para a atenção comunitária, além de experimentar a utilização de auxiliares de saúde na equipe de atenção primária, visando contri- 
buir para o aumento de cobertura de sistemas locais e regionais de serviços de saúde. Essa vivência levou José Paranaguá a se aproximar dos temas da área da saúde pública e, em especial, da formação de recursos humanos.

Em 1979, trabalhou no Departamento de Assuntos Universitários (atual Secretaria da Educação Superior) do Ministério da Educação e Cultura (MEC). Atuou na implantação da Comissão Nacional de Residência Médica e na regulamentação da residência em Medicina Preventiva e Social no país, além de apoiar as atividades da Comissão de Educação Médica do MEC.

Essas experiências foram o passaporte para o seu ingresso na Opas no final de 1979, na equipe do Programa de Preparação Estratégica de Pessoal de Saúde (Ppreps). O primeiro ciclo de suas atividades como consultor da Opas no Brasil se estendeu até 1985 , período em que se dedicou a iniciativas de integração docente-assistencial na graduação, à implantação de programas de residência em medicina preventiva e social e à avaliação das escolas médicas no Brasil, tendo também colaborado na estruturação de unidades de desenvolvimento de recursos humanos nas secretarias estaduais de saúde.

Assumiu em 1985 a Diretoria de Modernização Administrativa e Desenvolvimento de Recursos Humanos do Inamps/MPAS, posição que ocupou até 1988, período em que atuou na implantação da rede de núcleos acadêmicos de apoio à Reforma Sanitária, tendo ainda contribuído para a organização e implementação do Projeto Larga Escala, voltado para a qualificação de pessoal de nível médio.

A seguir, retomou a função de consultor da Opas no Brasil, tendo colaborado com a Comissão Interministerial de Planejamento e Coordenação (Ciplan), bem como no desenvolvimento de vários projetos nacionais de capacitação de dirigentes para o recém constituído Sistema Único de Saúde (SUS).

Em 1995 afastou-se novamente da Opas, quando assumiu o cargo de Coordenador Geral de Políticas de Recursos Humanos para o Sistema Único de Saúde (SUS), no Ministério da Saúde, até início de 1996. Nesse período contribuiu para o fortalecimento da articulação entre o Ministério da Saúde e as secretarias saúde, apoiando a criação da Câmara Técnica de Recursos Humanos do Conass e a Secretaria Extraordinária de Recursos Humanos do Conasems.

A partir de 1996 assumiu a coordenação do programa de cooperação técnica na área de políticas de recursos humanos da Representação Brasileira 
da Opas. Dentre outras atribuições, desenvolveu o projeto de redes colaborativas com apoio da Internet, sendo um dos articuladores da Rede Observatório de Recursos Humanos em Saúde, uma iniciativa continental da Opas que, no Brasil, conta com apoio do Ministério da Saúde, por intermédio da Secretaria de Gestão do Trabalho e da Educação na Saúde (Segetes).

José Paranaguá participou de cursos, seminários, encontros, debates e congressos no país e no exterior. Sua produção intelectual abrange temas relacionados à política de saúde, educação médica, regionalização e municipalização dos serviços de saúde, medicina preventiva e social no Brasil, formação profissional, cooperação técnica, reforma sanitária e gestão de recursos humanos em saúde. Ao longo desse período sua atuação mais expressiva deslocou-se da educação médica para a gestão de políticas de recursos humanos em saúde, tendo contribuído para o desenvolvimento de metodologias inovadoras na formação de gestores de políticas de recursos humanos (Projeto Cadrhu, desencadeado em 1987) e de gerentes das unidades básicas do SUS (Projeto Gerus, a partir de 1992).

Ao longo de sua vida profissional, José Paranaguá de Santana manteve vínculo com o serviço público no seu país, sendo atualmente médico da Fundação Oswaldo Cruz (Fiocruz), estando designado para o Programa de Saúde Internacional, objeto de um acordo de cooperação entre a Opas com o Governo brasileiro.

\section{José Roberto de Araújo Ferreira}

José Roberto Ferreira nasceu na cidade do Rio de Janeiro, em 6 de abril de 1934. Diplomou-se em Medicina pela Faculdade de Medicina da Universidade do Brasil em 1957, especializou-se em cirurgia no Instituto de Pesquisas Cardiovasculares e no Instituto de Cardiologia da Fundação Sabato D’ Ângelo. Exerceu a atividade de cirurgia até 1966, envolvendo-se em investigações direcionadas ao desenvolvimento da cirurgia cardiovascular tendo publicado, em co-autoria com Aluísio Amâncio e Hélio Barbosa, "Controle Clínico do Paciente Cirúrgico" (1962), um livro de ampla aceitação didática.

A partir do ano de 1962, José Roberto se envolveu em atividades vinculadas ao planejamento, organização e administração educacional na Universidade do Brasil, além colaborar no processo de estabelecimento da Escola Nacional de Saúde Pública (Ensp/Fiocruz), elaborando seu primeiro estatuto; 
participou da organização do Primeiro Exame de Vestibular Unificado para as áreas médicas de todas as Escolas do Rio de Janeiro.

Dentre os cargos e postos que ocupou neste período, José Roberto Ferreira foi Assessor da Divisão de Ensino Superior do Ministério de Educação e Cultura (1963-65), relator do Plano de Expansão das Escolas Médicas no país (1964) e assistente da Federação Pan-Americana de Associações de Faculdades e de Escolas de Medicina (1964-1965).

Em 1966 transferiu-se para o Distrito Federal, onde coordenou, na Universidade de Brasília, a implantação das faculdades das áreas de saúde e de tecnologia, bem como do seu hospital universitário, sempre na perspectiva de um ensino integrado das ciências da saúde. Foi Vice-Reitor até 1969, quando se licenciou.

Neste ano rumou para Washington, dando início à sua carreira internacional junto à Opas, onde exerceria um papel decisivo da área de desenvolvimento de recursos humanos em saúde, sob sua responsabilidade até meados da década de 1990, quando se aposentou.

Prestou assessoria a um extenso número de instituições de ensino superior e de pós-graduação em saúde. Neste particular foi personagem importante, ao lado de Juan César Garcia, da instalação dos primeiros mestrados latino-americanos em medicina social, entre 1974 e 1978. Promoveu a área de pesquisa em recursos humanos implementando, entre outras experiências, a linha de investigação sobre mercado e dinâmica da força de trabalho em saúde e a realização da Conferência Continental sobre Política de Pesquisa em Saúde.

Nesta condição esteve à frente de várias iniciativas entre as quais o Centro Latino-Americano de Tecnologia Educacional para a Saúde (Clates, 197273); o Programa de Pessoal Paramédico do Caribe Inglês (Allid Health Personnel, 1974-84); o Programa de Desenvolvimento da Medicina Veterinária (1975-79); o Programa Estratégico de Pessoal de Saúde (Ppreps, 1976-82); Programa de Adestramento em Saúde para Centro América e Panamá (Pascap, 1978-95); Programa de Treinamento em Saúde Internacional (1985-95); Revisão da Teoria e Prática da Saúde Pública (Conferência Pan-Americana, 19881994); Universidade e Saúde /Século XXI, (Usalc - XXI, 1990-95); Programa de Educação em Administração de Saúde (Proasa); Programa Latino-Americano de Desenvolvimento Educacional em Saúde (Plades); e Curso LatinoAmericano de Recursos Humanos em Saúde (Clarhus, desde 1992). 
José Roberto Ferreira produziu um total de 140 trabalhos, que se dividiram em diferentes temas no campo da saúde, que vão desde questões de interesse nacional a problemas ligados a ações de cooperação e assistência técnica internacional da Opas (Organização Pan-Americana da Saúde). Como coordenador da Série de Recursos Humanos da Opas, publicou mais de 102 livros nos quais deixou sua contribuição pessoal. Além disso, produziu muitos trabalhos isolados originados, em sua maioria, de congressos, conferências, reuniões, seminário, projetos, programas e simpósios. Exerceu a função de editor de Educación Médica y Salud, publicação periódica da Opas, especializada em recursos humanos, por de vinte anos, entre 1974 e 1994.

Foi agraciado em sua trajetória profissional com honrarias, prêmios e títulos de universidades e instituições brasileiras e latino-americanas, tais como: a Academia Nacional de Medicina, a Escola Médica do Rio de Janeiro, a Escola de Saúde Pública da Fundação Oswaldo Cruz, Escola Médica Militar da Colômbia e a Opas.

Atualmente, José Roberto Ferreira trabalha na Fiocruz, exercendo a função de coordenador da Assessoria de Cooperação Internacional.

\section{Roberto Passos Nogueira}

Roberto Passos Nogueira é natural de Fortaleza, Ceará, onde nasceu a 22 de janeiro de 1949. Concluiu a graduação em medicina pela Universidade Federal do Ceará em 1973. Realizou a residência médica em Medicina Social, no Instituto de Medicina Social da Universidade do Estado do Rio de Janeiro (Uerj), onde também obteve o título de mestrado em 1977, com a dissertação Medicina Interna e Cirurgia - a Formação Social da Prática Medicam, orientada por Sergio Arouca. Na própria Uerj, ingressou no doutorado, em 1995, defendendo a tese $A$ Saúde pelo Avesso: uma reinterpretação de Ivan Illich, o profeta da autonomia, sob orientação de Madel Therezinha Luz.

Em 1977, iniciou sua carreira profissional na Assessoria de Recursos Humanos, da Secretaria Geral do Ministério da Saúde. Em 1979, desenvolveu para o Ministério do Interior um estudo destinado ao planejamento integrado do desenvolvimento da Bacia do Alto Paraguai.

Em 1980 ingressa no Grupo Assessor Principal da cooperação técnica Opas-Brasil em recursos humanos, assumindo, em 1983, a função de coordenador da cooperação. Em finais deste ano foi substituído por Cesar 
Vieira. Desempenhou papel importante na organização e na relatoria da VIII Conferência Nacional de Saúde, marco na formulação do Sistema Único de Saúde. Em 1987, dirigiu-se a Washington, passando a atuar, na Opas, como consultor regional para o programa de recursos humanos em saúde.

Nos seus anos de trabalho junto à cooperação Opas-Brasil em RH, Nogueira participou ativamente da formulação do projeto Larga Escala, voltado para a formação em massa de pessoal de nível médio e elementar para a saúde, ao mesmo tempo em que procurava desenvolver o componente de pesquisa previsto na cooperação. $\mathrm{Na}$ sede da Opas, em Washington, Nogueira contribuiu para a constituição de uma área de pesquisa em recursos humanos, em particular em torno dos temas de mercado de trabalho e exercício profissional em saúde.

Em 1992, Nogueira se vinculou à Escola Nacional de Saúde Pública (Ensp/Fiocruz), desenvolvendo atividades nas áreas de ensino e pesquisa, em torno do tema da qualidade em saúde. Na Presidência da Fiocruz, desempenhou a função de coordenador de qualidade, junto às áreas de planejamento estratégico. Entre 1996 e 1997, atuou junto à Secretaria Executiva do Ministério da Saúde, na Coordenação de Recursos Humanos para o SUS.

Em 1998, ingressou no Instituto de Pesquisa Econômica Aplicada (Ipea) e desde então atua como pesquisador na linha de pesquisa "Saúde e Seguridade Social".

Roberto Passos Nogueira publicou artigos nos periódicos da Opas e em vários periódicos brasileiros dedicados aos temas de recursos humanos em saúde, saúde pública e administração pública. 


\section{REFERÊNCIAS}

\section{LIVROS E ARTIGOS}

AHUMADA, J. et al. Problemas Conceptuales y Metodológicos de la Programación de la Salud. Washington, D.C.: Opas, 1965. (Publicación Científica n. 111).

ALMEIDA, M. J. A educação médica e as atuais propostas de mudança: alguns antecedentes históricos. Revista Brasileira de Educação Médica, 25(2): 42-52, 2001.

ANDRADE, J. Marco Conceptual de la Educación Médica en la América Latina. Washington: Opas, 1979.

BARRANCOS, D. \& MENDES, E. V. Memoria de Planificadores: otra historia de la planificación de salud en America Latina. Washington, D.C.: Programa de Desarrollo de Políticas de Salud/Opas, 1992. (Série Informes Técnicos, 9). Disponível em: <www.paho.org/Spanish/HDP/HDD/IT9.PDF>. Acesso em: 11 set. 2006.

BREUNING, M. Foreign aid, development assistance, or development cooperation: what's in a name? International Politics, 39: 369-377, 2002.

BUSS, P. M. Medicina social no Brasil: esboço do perfil de um pioneiro. Cadernos de Saúde Pública, 4(3): 342-348, 1988. Disponível em: <www.scielo.br/ scielo.php?script $=$ sci_arttext\&pid $=$ S0102-311X1988000300010\&lng $=$ en\&nrm=iso $>$. Acesso em: 4 set. 2006.

CAMPOS, F. E. O sistema integrado de prestação de serviço de saúde do norte de Minas como espaço de atuação acadêmica. In: FLEURY, S. (Org.). Projeto Montes Claros: a utopia revisitada. Rio de Janeiro: Abrasco, 1995. 
CASTRO SANTOS, L. A. \& FARIA, L. R. A Reforma Sanitária no Brasil: ecos da Primeira República. São Paulo: Edusf, 2003.

CASTRO, J. L. \& SANTANA, J. P. S. \& NOGUEIRA, J. R. Irabel dos Santos: a arte e a paixão de aprender fazendo. Natal: Observatório RH Nesc/UFRN, 2002.

CASTRO, J. L. \& SANTANA, J. P. S. CADHRU: a história de um projeto. In: CASTRO, J. L. \& SANTANA, J. P. S. (Orgs.). Capacitação em Desenvolvimento de Recursos Humanos de Saúde. Natal: EDUFRN, 1999. Disponível em: <www.opas.org.br/rh/publicacoes/textos/pub04int.pdf>. Acesso em: 11 set. 2006.

CHAVES, M. M. Algumas reflexões sobre IDA: antecedentes do ideário UNI. Divulgação em Saúde para Debate, 9: 5-9, 1994.

COUTINHO, E. Frederico Adolfo Simões Barbosa (1916 -2004). Revista da Sociedade Brasileira de Medicina Tropical. [online], 37 (5): 427-428, 2004. Disponível em: $<$ http: / test.scielo.br/scielo.php?script=sci_arttext\&pid=S003786822004000500015\&lng=en\&nrm=iso $>$. Acesso em: 6 out. 2005.

CUETO, M. El Valor de la Salud: historia de la Organización Panamericana de la Salud. Washington, D.C.: OPS, 2004.

CUETO M. The origins of primary health care and selective primary health care. American Journal of Public Health, 94(11): 1864-1874, 2004a.

DONNANGELO, M. C. F. Saúde e Sociedade. São Paulo: Duas Cidades, 1976.

ESCOBAR, A. Encountering Development: the making and unmaking of the Third World. Princeton: Princeton University Press, 1995.

ESCOREL, S. \& NASCIMENTO, D. R. \& EDLER, F. As origens da Reforma Sanitária e do SUS. In: LIMA, N. T. et al. (Orgs.). Saúde e Democracia: história e perspectivas do SUS. Rio de Janeiro: Ed. Fiocruz, 2005.

ESCOREL, S. Reviravolta na Saúde: origem e articulação do movimento sanitário. Rio de Janeiro: Ed. Fiocruz, 1998.

FAUSTO, B. História do Brasil. São Paulo: Edusp, 2000.

FERREIRA, J. R. Estrategias internacionales en educación médica: asistencia técnica y cooperación técnica. Educación Médica y Salud, 10(4): 335-344, 1976.

FEUERWERKER, L. C. M. \& MARSIGLIA, R. Estratégias para mudanças na formação de RHs com base nas experiências IDA/UNI. Divulgação em Saúde para Debate, 12: 24-28, 1996.

FEUERWERKER, L.C.M. Mudanças na Educação Médica e Residência Médica no Brasil. São Paulo: Hucitec/Rede Unida, 1998.

FINNEMORE, M. National Interests in International Society. Ithaca: Cornell University Press, 1996.

FÜLÖP, T. \& ROEMER, M. I. International Development of Health Manpower Policy. Genebra: OMS, 1982. 
GARCÍA, J. C. La Educación Médica en la América Latina. s. 1.: Opas/OMS, 1972. GIOVANELLA, L. A proposta de Mário Testa para o planejamento em saúde. In: GIOVANELla, L (Org.). Planejamento Estratégico, Programação e Orçamentação em Saúde: textos de apoio ao ensino da saúde coletiva. Rio de Janeiro: SDE/Ensp/Fiocruz, 1992.

GIOVANELLA, L. As origens e as correntes atuais do enfoque estratégico em planejamento de saúde na América Latina. Cadernos de Saúde Pública, 7(1): 26-44, 1991. Disponível em: <www.scielo.br/scielo.php?script =sci_arttext\&pid=S0102-311X1991000100004>. Acesso em: 6 set. 2006.

GIOVANELLA, L. Ideologia e Poder no Planejamento Estratégico em Saúde: uma discussão da abordagem de Mário Testa, 1989. Dissertação de Mestrado, Rio de Janeiro: Escola Nacional de Saúde Pública, Fundação Oswaldo Cruz.

GREMAUD, A. P.; VASCONCELLOS, M. A. \& TONETO JR., R. Economia Brasileira Contemporânea. São Paulo: Atlas, 2002.

HAMILTON, W. \& AZEVEDO, N. Um estranho no ninho: memórias de um ex-presidente da Fiocruz. História, Ciências, Saúde - Manguinhos, 8(1): 237-264, 2001. Disponível em: $<$ www.scielo.br/scielo.php?script=sci_arttext\&pid=S010459702001000200011\&lng=pt\&nrm=iso>. Acesso em: 15 set. 2006.

HERZ, M. \& HOFFMANN, A. R.. Organizacões Internacionais: história e práticas. Rio de Janeiro: Elsevier, 2004.

HORWITZ, A. El desarrollo económico y el bienestar social. Boletin de la Organización Sanitaria Panamericana, p. 387-389, nov. 1961.

HORWITZ, A. Planificación del desarrollo económico y social en América Latina. Boletin de la Organización Sanitaria Panamericana, p. 379-386, nov. 1961a.

HORWITZ, A. Evolución de la educación médica en la América Latina. Boletín de la Oficina Sanitaria Panamericana, 4(52): 281-289, 1962.

KEMP, A. \& EDLER, F. A reforma médica no Brasil e nos Estados Unidos: uma comparação entre duas retóricas. História, Ciências, Saúde- Manguinhos, 11(3): 569-585, 2004. Disponível em: <www.scielo.br/scielo.php? script=sci_arttext\&pid $=$ S $0104-59702004000300003 \& \operatorname{lng}$

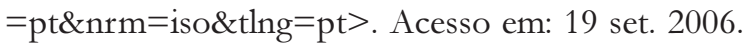

LAMPERT, J. B. Tendências de Mudanças na Formação Médica no Brasil: tipologia das escolas. São Paulo: Hucitec/Abem, 2002.

LEE, P. R. Medicine and public health in the People's Republic of China. The Western Journal of Medicine, 120(5): 430-437, 1974.

LESSA, C. A. Estratégia do Desenvolvimento 1974-1976: sonho e fracasso. Campinas: Instituto de Economia/Unicamp, 1998. (Coleção 30 Anos). 
LIMA, N. T. O Brasil e a Organização Pan-Americana da Saúde: uma história em três dimensões. In: FINKELMAN, J. (Org.). Caminhos da Saúde Pública no Brasil. Rio de Janeiro: Ed. Fiocruz, 2002.

LIMA, N. et al. (Org.). Saúde e Democracia: história e perspectivas do SUS. Rio de Janeiro: Ed. Fiocruz, 2005.

MACEDO, C. G. \& SANTOS, I. \& VIEIRA, C. A. B. Uma experiência de formação de pessoal de saúde no Brasil. Educación Médica y Salud, 14 (1): 6275, 1980 .

MARINHO, M. G. S. M. C. Norte-americanos no Brasil: uma bistória da Fundação Rockefeller na Universidade de São Paulo (1934-1952). Campinas: Editores Associados/Universidade de São Francisco, 2001.

MARSIGLIA, R. G. Relação Ensino/Serviços: dez anos de integração docente-assistencial (IDA) no Brasil. São Paulo: Hucitec, 1995.

MENDES, E. V. O Planejamento da Saúde no Brasil: origens, evolução, análise crítica eperspectivas. Brasilia: Opas, 1988. (Série Desenvolvimento de Serviços de Saúde, 8).

MORALES, H. D. Aspectos Conceptuales y Operativos del Proceso de Planificación de la Salud. Santiago de Chile: Instituto Latinoamericano y del Caribe de Planificación Económica y Social, 1989. (Série Cuadernos del Ilpes, 35). Disponível em: <www.eclac.cl/cgi-bin/getProd.asp?xml=/publicaciones / $\mathrm{xml} / 7 / 24507 / \mathrm{P} 24507 . \mathrm{xml} \& \mathrm{xsl}=/ \mathrm{ilpes} / \mathrm{tpl} / \mathrm{p} 9 \mathrm{f} . \mathrm{xsl} \& \mathrm{base}=/ \mathrm{ilpes} / \mathrm{tpl} / \mathrm{top}-$ bottom.xsl>. Acesso em: 18 set. 2006.

NORONHA, J. C. et al. Transformações de um ambulatório de medicina integral com vistas a um programa de atenção médica primária: a experiência do Hospital das Clínicas da Universidade do Estado do Rio de Janeiro, Brasil. Revista de Saúde Pública, 11(4): 429-443, 1977. Disponível em: <www.scielo.br/ scielo.php?script=sci_abstract\&pid=S0034-89101977000400001\&lng $=$ pt\&nrm=iso\&tlng=pt.> Acesso em: 4 set. 2006.

NERHUS (Núcleo de Recursos Humanos em Saúde/Ensp/Fiocruz). A política de recursos humanos nos anos recentes. In: MÉDICI, A. (Org.). Recursos Humanos em Saúde: textos de Apoio - Planejamento I. Rio de Janeiro: PEC-EnspFiocruz/Abrasco, 1987.

NUNES, E. D. Ensinando ciências sociais em uma escola de medicina: a história de um curso (1965-90). História Ciências, Saúde - Manguinhos, VI(3): 631-657, $1999 / 2000$.

NUNES, T. C. M. Editorial. Cadernos de Saúde Pública, 2 (4), 1986.

NUNES, T. C. M. A Especialização em saúde pública e os serviços de saúde no Brasil de 1970 a 1989, 1998. Tese de Doutorado, Rio de Janeiro: Escola Nacional de Saúde Pública, Fundação Oswaldo Cruz. Disponível em: $<w w w . p o r t a l t e s e s . c i c t . f i o c r u z . b r / t r a n s f . p h p ? s c r i p t=t h e s \_c o v e r \& i d$ $=000101 \& \operatorname{lng}=$ pt\&nrm=iso $>$. Acesso em: 18 set. 2006 . 
OEA (Organização dos Estados Americanos). Carta de Punta Del Este. Boletín de la Oficina Sanitaria Panamericana, p. 477-488, nov. 1961.

OPS (Organización Panamericana de la Salud). Reunión de Ministros de Salud (Grupo de Estudio). Washington, D.C.: Oficina Sanitaria Panamericana, 1963.

OPS (Organización Panamericana de la Salud). Pro Salute Novi Mundi: historia de la Organización Panamericana de la Salud. Washington, D.C.: Opas, 1992.

OPS/FEPAFEM (Organización Panamericana de la Salud/La Federación Panamericana de Asociaciones de Facultades (Escuelas) de Medicina). Informe final do Grupo de Trabalho sobre Requisitos Mínimos para a Criação de Escolas de Medicina. Educación Médica y Salud, 13(3): 274-287, 1979.

PAIM, J. S. Medicina preventiva e social no Brasil: modelos, crises e perspectivas. Saúde em Debate, 11: 57-59, 1981.

PAIM, J. S. Ações integradas de saúde (AIS): por que não dois passos atrás. Cadernos de Saúde Pública, 2(2): 167-183, 1986.

PAIVA, C. H. A. A Organização Pan-Americana da Saúde (Opas) e a Reforma de Recursos Humanos na Saúde na América Latina (1960-1970). Rio de Janeiro, 2005. Disponível em: <www.coc.fiocruz.br/observatoriohistoria/opas/ producao/arquivos/OPAS.pdf. Acesso em: 16 ago. 2006.

PEREIRA, I. B. \& RAMOS, M. N. Educação Profissional em Saúde. Rio de Janeiro: Ed. Fiocruz, 2006.

PIERANTONI, C. R.; VARELLA, T. C. \& FRANÇA, T. Recursos humanos e gestão do trabalho em saúde: teoria para a prática. Cadernos RH Saúde, 3(1): 29-40, 2006.

PIRES-ALVES, F. A. A Biblioteca da Saúde das Américas: a Bireme e a informação em ciências da saúde (1967-1982), 2005. Dissertação de Mestrado, Rio de Janeiro: Programa de Pós-Graduação em Ciências e Saúde da Casa de Oswaldo Cruz/Fiocruz.

ROCHA, J. S. Y. A integração docente assistencial na educação médica no Brasil. Revista Brasileira de Educação Médica, 9(3): 198-206, 1985.

RODRIGUEZ NETO, E. Integração Docente-assistencial em Saúde: origens, implicações e perspectivas, 1979. Dissertação de Mestrado, São Paulo: Departamento de Medicina Preventiva, Universidade de São Paulo.

SANTANA, J. P. S. A função de desenvolvimento de recursos humanos do Inamps/MPAS. Cadernos de Saúde Coletiva, 2(4): 570-575, 1986. Disponível em: <www.scielosp.org/scielo.php?script =sci_arttext\&pid=S0102311X1986000400015\&lng=en\&nrm=isso >. Acesso em: 19 set. 2006.

SAYD, J. D.; VIEIRA JUNIOR, L. \& VELANDIA, I. C. Recursos humanos nas Conferências Nacionais de Saúde (1941-1992). Physis: Revista de Saúde Coletiva, 8 (2): 165-95, 1998. 
SCHRAIBER, L. B. Educação Médica e Capitalismo: um estudo das relações educação e prática médica na ordem social capitalista. São Paulo/Rio de Janeiro: Hucitec/ Abrasco, 1989.

SIDDIQI, J. World Health and World Politics: the World Health Organization and the UN system. Londres: Hurst and Co., 1995.

SILVA, M. R. B. da; FERLA, L. \& GALLIAN, D. M. C. Uma 'biblioteca sem paredes': história da criação da Bireme. História, Ciência, Saúde - Manguinhos, 13 (1): 91-112, 2006.

SKIDMORE, T. Brasil: de Castelo a Tancredo, 1964-1985. Rio de Janeiro: Paz e Terra, 1988.

SKIDMORE, T. Brasil: de Getúlio a Castelo. Rio de Janeiro: Paz e Terra, 2004.

SORIO, R. Educação Professional em Saúde no Brasil: a proposta das Escolas Técnicas de Saúde do Sistema Único de Saúde. Formação: Projeto de Profissionalização dos Trabalhadores da Área de Enfermagem, 2 (5): 45-53, 2002.

SOUZA, A. M. de A. et al. Processo Educativo nos Serviços de Saúde. Brasília: Opas, 1991. (Série Desenvolvimento de Recursos Humanos, n. 1).

STERN, S. J. The decentered center and the expansionist periphery: the paradoxes of foreign-local encounters. In: JOSEPH, G. M.; SALVATORE, R. D. \& LE GRAND, C. (Eds.) Close Encounter of Empire: writing the cultural history of U. S. - Latin American relations. Durham: Duke University Press, 1998.

VELLOSO, J. P. R. O II PND e as oportunidades do Brasil. In: VELLOSO, J. P. R. (Org.) II PND. Rio de Janeiro: IBGE, 1975.

VERAS, R.P. A Abem e as Transformações da Prática Médica no Brasil, 1981. Dissertação de Mestrado, Rio de Janeiro: Instituto de Medicina Social, Universidade do Estado do Rio de Janeiro.

\section{DOCUMENTOS TEXTUAIS}

BRASIL. Presidência da República. Segundo (II) Plano Nacional de Desenvolvimento (PND): 1975-1979. Brasília/Rio de Janeiro: IBGE, 1974.

BRASIL. Ministério da Saúde. Portaria n. 271, de 12 de junho de 1974. Brasília, 1974.

BRASIL. Lei n. 6.229, de 17 de julho de 1975.

BRASIL. Ministério da Saúde. V Conferência Nacional de Saúde, 5-8 ago 1975, Brasília. Anais... Brasília, 1976.

BRASIL. Ministério da Educação e Cultura. Estudo sobre a formação e utiliqação dos recursos humanos na área da saúde. Brasília: Departamento de Documentação e Divulgação, 1976. 
BRASIL. Câmara dos Deputados. I Simpósio Sobre Política Nacional de Saúde. Brasília: Câmara dos Deputados, 1980.

BRASIL. Ministério da Educação e Cultura. Programa de Integração Docente Assistencial (IDA). Brasília: MEC/SESu, 1981. (Série Cadernos de Ciências da Saúde, 3).

BRASIL. Ministério da Educação e Cultura. Relatório do Grupo Interministerial de Recursos Humanos para a Saúde. Brasília: MEC/SESu, 1981. (Série Cadernos de Ciências da Saúde, 4).

BRASIL. MPAS. Ações Integradas de Saúde. MPAS/MS/MEC/Governos estaduais/ Governos municipais, 1984. (Mimeo).

BRASIL. Ciplan. Resolução Ciplan n. 15, de 19 de novembro de 1985. Brasília, 1985.

BRASIL. Ministério da Saúde. Secretaria Geral de Recursos Humanos. Conferência Nacional de Recursos Humanos: Relatório Final. Brasília, 1986.

BRASIL. VIII Conferência Nacional de Saúde. (Brasília, 17-21 mar. 1986) Brasília: MS/MPAS, 1986.

CADRHU. Curso de Aperfeiçoamento em Desenvolvimento de Recursos Humanos de Saúde. Brasília: Opas, 1991. (Série Desenvolvimento de Recursos Humanos, 3).

GERUS. Capacitação em Gerência de Unidades Básicas de Saúde do Distrito Sanitário. Brasília: Opas, 1993. (Série Desenvolvimento de Recursos Humanos, 4). Disponível em: <www.planalto.gov.br/CCivil_03/Leis/ L6229.htm>. Acesso em: 21 set. 2006.

OEA (Organización de los Estados Americanos). Declaración a los Pueblos de América. Carta de Punta del Este, Plano Decenal de Educación (Anexo I) e Plano Decenal de Salud Pública de la Aliança para el Progresso (Anexo II). (Documentos finais da Reunião Extraordinária do Conselho Interamericano Econômico e Social em Nível Ministerial. Punta del Este, ago. 1961). Boletín de la Oficina Sanitaria Panamericana, p. 475-493, nov. 1961.

OPAS/OMS (Organização Pan-Americana de Saúde/Organização Mundial da Saúde). Conferência Panamericana sobre Planificação de Recursos Humanos em Saúde (Otawa, Canadá, 1972). Washington, D.C.: Opas, 1972. (Publicação Científica, n. 279).

OPAS (Organização Pan-Americana da Saúde)/BRASIL. Acordo para um Programa Geral de Desenvolvimento de Recursos Humanos para a Saúde no Brasil. Brasília: 14 dez. 1973.

OPAS (Organização Pan-Americana da Saúde)/BRASIL. Acordo Complementar ao Acordo para um Programa Geral de Desenvolvimento de Recursos Humanos para a Saúde no Brasil. Brasília, 8 ago. 1975a. 
OPAS (Organização Pan-Americana da Saúde)/BRASIL. Termo Aditivo ao Acordo Complementar para um Programa Geral de Desenvolvimento de Recursos Humanos para a Saúde no Brasil. Brasília, 8 ago. 1975b.

OPAS (Organização Pan-Americana da Saúde)/BRASIL. Termo Aditivo ao Acordo Complementar para um Programa Geral de Desenvolvimento de Recursos Humanos para a Saúde no Brasil. Brasília, 21-29 dez. 1978.

OPAS (Organização Pan-Americana da Saúde)/BRASIL. Acordo Complementar ao Acordo para um Programa Geral de Desenvolvimento de Recursos Humanos para a Saúde no Brasil. Brasília, 2 ago. 1979.

OPAS (Organização Pan-Americana da Saúde)/BRASIL. Segundo Termo Aditivo ao Acordo para um Programa Geral de Desenvolvimento de Recursos Humanos para a Saúde no Brasil. Brasília: 17 mar. 1980.

OPAS (Organização Pan-Americana da Saúde)/BRASIL. Projeto Larga Escala: relatório 1982-1984. Brasília, 1985a. (Mimeo).

OPAS (Organização Pan-Americana da Saúde)/BRASIL. Nono Termo Aditivo ao Acordo para um Programa Geral de Recursos Humanos para a Saúde no Brasil. Brasília, 1985.

OPS (Organização Panamericana de la Salud). Hechos sobre Problemas de Salud: la salud en relación com el progreso social y el desarrollo económico de las Américas. Documento de referência elaborado pela OPS para a Reunião Extraordinária do Conselho Interamericano Econômico e Social em Nível Ministerial. Punta del Este, 1961. Disponível em: <www.hist.library.paho.org/English/MPUB/ MPUB63A.pdf. $>$.

OPS (Organización Panamericana de la Salud). Informe sobre la III Reunión Especial de Ministros de Salud y medidas necesarias para dar cumplimiento a las decisiones adoptadas. Washington, D.C., 1972.

OPS/OMS (Organización Panamericana de la Salud/Organização Mundial da Saúde). Editorial. Boletin de la Organización Panamericana de la Salud, nov. 1961.

OPS/OMS (Organización Panamericana de la Salud/Organização Mundial da Saúde). Reunión de Ministros de Salud (Grupo de Estudio). Washington, D.C.: Oficina Sanitaria Panamericana, 1963.

OPS/OMS (Organización Panamericana de la Salud/Organização Mundial da Saúde). Estudio de recursos humanos para la salud pública de Colombia y Asociación Colombiana de Facultades de Medicina. Conferência Internacional sobre Recursos Humanos para a Saúde e Educação Médica, ago. 1967, Maracay, Vanezuela, 1967.

OPS/OMS (Organización Panamericana de la Salud/Organização Mundial da Saúde). Reunión de Ministros de Salud de las Américas. Documentos de trabajo. 
Buenos Aires, 14-18 out. 1968. Documento Oficial n. 90. Washington, D.C.: OPS, 1969.

OPS/OMS (Organización Panamericana de la Salud/Organização Mundial da Saúde). Reunión de Ministros de Salud de las Américas. Informe finaly discursos. Buenos Aires, 14-18 outubro de 1968. Documento Oficial n. 90. Washington, D.C.: Opas, 1969.

OPS/OMS (Organização Panamericana de la Salud/Organização Mundial da Saúde). Resolução 25. XXIX Reunião do Conselho Diretor (29 set. - 3 out.). Washington, D.C., 1983.

OPS/OMS (Organização Panamericana de la Salud/Organização Mundial da Saúde). Los Centros Panamericanos. Documento. SPP36/11 (Esp.). 36ª Sessão do Subcomitê de Planificação e Programação do Comitê Executivo. Washington, 2002.

PDRHS. Programa de Desenvolvimento de Recursos Humanos para a Saúde. Brasilia: Opas, jan. 1985a. (Mimeo).

PDRHS. Sistematização dos dados dos relatórios informativos dos estados 1982-1984. Projeto Larga Escala. (Anexo a PDRHS, 1985a). 1985b. (Mimeo).

PPREPS. Programa de Preparação Estratégica de Pessoal de Saúde - Opas/ Brasil. Brasília: MS/MEC/Opas, jun. 1976.

PPREPS. Programa de Preparação Estratégica de Pessoal de Saúde - Opas/ Brasil. Relatório anual de 1978. Brasília: MS/MEC/Opas, mar. 1979.

PREV-SAÚDE. Programa Nacional de Serviços Básicos de Saúde - MS/MPAS. 1981. (Mimeo).

SESU/MEC (Secretaria de Ensino Superior). Programa de Integração Docente-Assistencial. Brasilia: MEC/SESU, 1981 (Série Cadernos de Ciências da Saúde, n. 3).

SESU/MEC. Secretaria de Ensino Superior. Relatório do Grupo Interministerial de Recursos Humanos para a Saúde. Brasília: MEC/SESU, 1981a. (Série Cadernos de Ciências da Saúde, n. 4).

\section{DEPOIMENTOS ORAIS}

FERREIRA, J. R.. Depoimento a Carlos H. A. Paiva, Fernando Pires-Alves, Gilberto Hochman e Janete Castro. (Rio de Janeiro, 15-16 de março de 2005). Transcrito por Annabella Blyth. Conferência por fidelidade por Alex dos Santos da Silveira. 4 horas.

GARCIA, D. P. Depoimento a Carlos H. A. Paiva e Regina C. Marques. (Rio de Janeiro, 15 de dezembro de 2005). Transcrito por Andrea Ribeiro. Conferência de fidelidade por Alex dos Santos da Silveira. 7 horas e meia. 
MACEDO, C. G. de. Depoimento a Carlos H. A. Paiva, Fernando Pires-Alves, Gilberto Hochman e Janete Castro. (Brasília, 1-2 de março de 2005). Transcrito por Annabella Blyth. Conferência de fidelidade por Alex dos Santos da Silveira. 5 horas.

NOGUEIRA, R. P. Depoimento a Carlos H. A. Paiva e Janete Castro. (Rio de Janeiro, 26 de julho de 2005). Transcrito por Andrea Ribeiro. Conferência de fidelidade por Alex dos Santos da Silveira. 4 horas.

PELLEGRINI, A. Depoimento a Carlos H. A. Paiva e Gilberto Hochman. (Rio de Janeiro, 7 de junho de 2005.) Transcrito por Andrea Ribeiro. Conferência de fidelidade por Alex dos Santos da Silveira. 2 horas e meia.

SANTANA, J. F. P. Depoimento a Carlos H. A. Paiva, Fernando Pires-Alves, Gilberto Hochman e Janete Castro. (Rio de Janeiro, 21-22 de fevereiro de 2005). Transcrito por Andréa Ribeiro. Conferência de fidelidade por Alex dos Santos da Silveira. 5 horas.

SANTANA, J. F. P. Depoimento a Carlos H. A. Paiva e Fernando Pires-Alves [Entrevista II]. (Brasília, outubro de 2006). Transcrito por Andréa Ribeiro. Conferência de fidelidade por Alex dos Santos da Silveira. 5 horas.

SANTOS, I. dos. Izabel dos Santos: a arte e a paixão de aprender fazendo. Depoimento a Janete Lima de Castro, José Paranaguá de Santana e Roberto Passos Nogueira. Natal: Ed. Observatório RH/NESC/UFRN, 2002.

VIEIRA, C. Depoimento a Carlos H. A. Paiva e Regina C. Marques. (Rio de Janeiro, 14 de outubro de 2005). Transcrito por Andrea Ribeiro. Conferência de fidelidade por Alex dos Santos da Silveira. 3 horas e meia.

\section{Bibliografia}

AROUCA, S. O Dilema Preventivista: contribuição para a compreensão e crítica da medicina preventiva. São Paulo/Rio de Janeiro: Unesp/Ed. Fiocruz, 2003.

ABEM (Associação Brasileira de Escolas Médicas). II Reunião Anual da Associação Brasileira de Escolas Médicas. Anais... Rio de Janeiro: Abem, 1964.

BRASIL. Ministério da Educação e Cultura. Estudo sobre a Formação e Utilização dos Recursos Humanos na Área da Saúde. Brasília: Departamento de Documentação e Divulgação Universitária, 1976.

BRASIL. Ministério da Saúde. Recursos Humanos para Serviços Básicos de Saúde: formação de pessoal de niveis médio e elementar pelas instituições de saúde. Brasília: Centro de Documentação do Ministério da Saúde, 1982.

BROWN, T.; CUETO, M. \& FEE, E. A transição da saúde pública "internacional” para "global” e a Organização Mundial de Saúde. História, Ciências, Saúde Manguinhos, 13(3): 603-620, 2006. 
CAMPOS, A. Combatendo nazistas e mosquitos: militares norte-americanos no Nordeste brasileiro (1941-1945). História, Ciências, Saúde - Manguinhos, 5(3): 603-620, 1999. Disponível em: <www.scielo.br/ scielo.php?script $=$ sci_arttext\&pid $=$ S0104-59701999000100004\&lng $=$ pt\&nrm=iso $>$. Acesso em: 11 set. 2006.

CAMPOS, A. Políticas internacionais de saúde na era Vargas: o Serviço Especial de Saúde Pública. In: GOMES, A. C. (Org.). Capanema: o ministro e seu ministério. Rio de Janeiro: Fundação Getulio Vargas, 2000.

CAMPOS, F. E. et al. Caminhos para aproximar a formação de profissionais de saúde das necessidades da atenção básica. Revista Brasileira de Educação Médica, 25(2): 53-59, 2001.

CENTRO PANAMERICANO DE PLANIFICACIÓN DE LA SALUD/OPS/ OMS. Formulación de Politicas de Salud. Santiago de Chile, jul. 1975.

CHAVES, M. \& REIS, A. R. Educação Médica nas Américas: o desafio dos anos 90. São Paulo: Cortez, 1990.

DUQUE, L. F. (Org.). Recursos Humanos y Salud: documentos de la Conferencia Panamericana sobre Recursos Humanos y Atención Médica - el personal de niveles medio y básico como factor de cambio en los sistemas de salud. Medellín: Federación Panamericana de Asociaciones de Facultades (Escuelas) de Medicina, 1977.

ELZINGA, A. A Unesco e a política de cooperação internacional no campo da ciência. In: MAIO, M.C. (Org). Ciência, Politica e Relacões Internacionais: ensaios sobre Paulo Carneiro. Rio de Janeiro: Ed. Fiocruz, 2004.

FANUCK, L. C. O Estado, os serviços públicos e a administração de pessoal. Cadernos de Saúde Pública, 2(4): 440-448, 1986. Disponível em: <www.scielo.br/ scielo.php?script $=$ sci_arttext\&pid $=$ S0102-311X1986000400004\&lng $=\mathrm{pt} \& \mathrm{nrm}=$ iso\&tlng $=\mathrm{pt}>$. Acesso em: 19 set. 2006.

KOVARICK, L. Estratégias do Planejamento Social no Brasil. São Paulo: Cebrap, s.d. (Cadernos Cebrap, 2).

LIMA, N. T.; FONSECA, C. M. \& SANTOS, P. R. E. (Org.) Uma Escola Para a Saúde. Rio de Janeiro: Ed. Fiocruz, 2004.

LUZ, M. T. As Instituições Médicas no Brasil: instituições e estratégias de hegemonia. Rio de Janeiro: Graal, 1979.

MACHADO, M. H. Trabalhadores da saúde e sua trajetória na Reforma Sanitária. In: LIMA, N. T. et al. (Orgs.). Saúde e Democracia: história e perspectivas do SUS. Rio de Janeiro: Ed. Fiocruz, 2005.

MAIO, M. C. Demandas globais, respostas locais: a experiência da Unesco na periferia no pós-guerra. In: MAIO, M. C. (Org.). Ciência, Política e Relacões Internacionais: ensaios sobre Paulo Carneiro. Rio de Janeiro: Ed. Fiocruz, 2004. 
NOGUEIRA, R. P. Pessoal de saúde: a discussão teórica e a produção científica sobre o tema. In: NUNES, E. (Orgs). As Ciências Sociais em Saúde na América Latina. Brasília: Opas, 1985.

NOVAES, H. M. Ações Integradas nos Sistemas Locais de Saúde - Silos: análise conceitual e apreciação de programas selecionados na América Latina. São Paulo: PROAHSA, 1990.

PAIVA, C. H. A. A Utopia Burocrática: um estudo bistórico-comparativo das políticas públicas de saúde - Rio de Janeiro e São Paulo (1930-1960). Tese de Doutorado, Rio de Janeiro: Programa de Pós-Graduação em Saúde Coletiva, do Instituto de Medicina Social (IMS/Uerj), 2004

PEDRAZZANI, J. C. Formação do profissional de saúde, estrutura ocupacional e demandas educacionais. Revista Brasileira de Enfermagem, 33: 477-482, 1980.

PIERANTONI, C. R. As reformas do Estado, da saúde e recursos humanos: limites e possibilidades. Ciência \& Saúde Coletiva, 6(2): 341-360, 2001. Disponível em: <www.scielo.br/scielo.php?script=sci_arttext\&pid=S1413$81232001000200006 \& \operatorname{lng}=$ pt\&nrm $=$ iso\&tlng=pt $>$. Acesso em: 18 set. 2006.

PINHEIRO, L. Política Externa Brasileira, 1889-2002. Rio de Janeiro: Jorge Zahar, 2004.

RANGEL, M. L. \& VILASBOAS, A. L. Rede Unida: breve histórico, concepção, organização e estratégias de ação. Divulgação em Saúde para Debate, 1(12): 1518, 1996.

ROSEN, G. Uma História da Saúde Pública. São Paulo/Rio de Janeiro: Unesp/ Abrasco, 1994.

SANTOS, I. Ensino de nível médio: perspectivas dos serviços. Cadernos de Saúde Pública, 2(4): 461-465, 1986. Disponível em: <www.scielo.br/ scielo.php?script $=$ sci_arttext $\&$ pid $=$ S0102-311X1986000400006\&lng $=$ pt\&nrm $=$ iso\&tlng $=$ pt $>$. Acesso em: 19 set. 2006.

SANTOS, I. \& SOUZA, A. Formação de pessoal de nível médio pelas instituições de saúde: Projeto Larga Escala, uma experiência em construção. Saúde em Debate, 25: 61-64, 1989.

SILVA, L. A. S. R. A educação médica e a reforma sanitária. Cadernos de Saúde Pública, 2(4): 4 93-504, 1986. Disponível em: <www.scielo.br/ scielo.php? script $=$ sci_arttext\&pid $=$ S0102-311X1986000400009\&lng $=$ pt\&nrm $=$ iso\&tlng $=$ pt $>$. Acesso em: 19 set. 2006.

SIMÕES, A. P. Os núcleos de desenvolvimento de recursos humanos para a saúde. Cadernos de Saúde Pública, 2(4): 533-560, 1986. Disponível em: $<$ www.scielo.br/scielo.php?script $=$ sci_arttext\&pid=S0102$311 \mathrm{X} 1986000400013 \& \operatorname{lng}=\mathrm{pt \& nrm}=\mathrm{iso} \& \mathrm{t} \operatorname{lng}=\mathrm{pt}>$. Acesso em: 19 set. 2006. 
SONIS, A. Escuelas de salud pública: tendencias y perspectivas para la década del 70. Educación Médica y Salud, 6(1): 19-42, 1972.

SONIS, A. Educación en ciencias de la salud y atención médica: análisis de su interrelación. Educación Médica y Salud, 10(3): 234-253, 1976.

SÓRIO, R. \& LAMARCA, I. Novos desafios das escolas técnicas de saúde do SUS. Physis: Revista de Saúde Coletiva, 8(2): 147-164, 1998.

TEIXEIRA, C.F.S. Educação e Saúde: contribuição ao estudo da formação dos agentes das práticas de saúde no Brasil, 1982. Dissertação de Mestrado em Saúde Comunitária, Salvador: Faculdade de Medicina, Universidade Federal da Bahia.

URQUIDI, V. L. Free trade experience in Latin America and the Caribbean. Annals of the American Academy of Political and Social Science, v. 526. Free Trade in the Western Hemisphere. (Mar. 1993), p. 58-67.

VIDAL, C. A. \& QUIÑONES, J. Integración docente-asistencial. Educación Médica y Salud, 20(1): 1-25, 1986. 
Formato: $16 \times 23 \mathrm{~cm}$

Tipologia: Humanist e Garamond

Papel: Pólen Soft $80 \mathrm{~g} / \mathrm{m}^{2}$ (miolo)

Cartão Supremo $250 \mathrm{~g} / \mathrm{m}^{2}$ (capa)

Fotolitos: Laser vegetal (miolo)

Engenho \& Arte Editoração Gráfica Ltda. (capa)

Impressão e acabamento: Imprinta Express Gráfica e Editora Ltda.

Rio de Janeiro, novembro de 2006.

Não encontrando nossos títulos em livrarias, contactar a EDITORA FIOCRUZ:

Av. Brasil, $4036-1^{\circ}$ andar - sala 112 - Manguinhos

21040-361 - Rio de Janeiro - RJ

Tel.: (21) 3882-9039 e 3882-9041

Telefax: (21) 3882-9006 e 3882-9007

http//www. fiocruz.br/editora

e-mail: editora@fiocruz.br 